\title{
Accelerator Production of Tritium Pollution Prevention Design Assessment
}

by

R. Reynolds

Westinghouse Savannah River Company

Savannah River Site

Aiken, South Carolina 29808

P. Nowacki

A document prepared for EIS REFERENCES at , , from - .

\section{MASTER}

DOE Contract No. DE-AC09-96SR18500

This paper was prepared in connection with work done under the above contract number with the U.S.

Department of Energy. By acceptance of this paper, the publisher and/or recipient acknowledges the U.S. Government's right to retain a nonexclusive, royalty-free license in and to any copyright covering this paper, along with the right to reproduce and to authorize others to reproduce all or part of the copyrighted paper. 


\section{DISCLAIMER}

This report was prepared as an account of work sponsored by an agency of the United States Government. Neither the United States Government nor any agency thereof, nor any of their employees, makes any warranty, express or implied, or assumes any legal liability or responsibility for the accuracy, completeness, or usefulness of any information, apparatus, product, or process disclosed, or represents that its use would not infringe privately owned rights. Reference herein to any specific commercial product, process, or service by trade name, trademark, manufacturer, or otherwise does not necessarily constitute or imply its endorsement, recommendation, or favoring by the United States Government or any agency thereof. The views and opinions of authors expressed herein do not necessarily state or reflect those of the United States Government or any agency thereof.

This report has been reproduced directly from the best available copy.

Available to DOE and DOE contractors from the Office of Scientific and Technical Information, P. O. Box 62, Oak Ridge, TN 37831; prices available from (423) 576-8401.

Available to the public from the National Technical Information Service, U. S. Department of Commerce, 5285 Port Royal Road, Springfield, VA 22161. 


\section{DISCLAIMER}

Portions of this document may be illegible electronic image products. Images are produced from the best available original document. 


\section{WSRC-TR-97-0260}

Accelerator Production of Tritium

Pollution Prevention Design Assessment (U)

\section{Co-Authors}

Paul Lanik, Burns \& Roe Engineering Inc. Stephen O. Sheetz, WSRC

Westinghouse Savannah River Company Aiken, SC 29808 
WSRC-TR-97-0260

Accelerator Production of Tritium

Pollution Prevention Design Assessment (U)

Rev. 0

September 18, 1997

Lead Author:

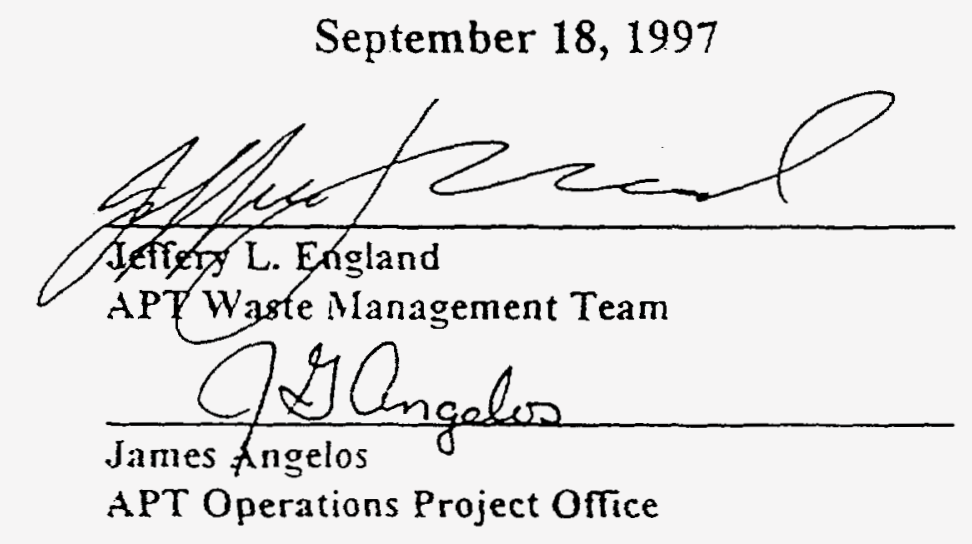

Approved by:

Date: $\underbrace{18 \operatorname{sep}^{97}}_{1}$

Date: $9 / 23 / 97$ 


\section{List of Acronyms, Abbreviations, and Symbols}

$\begin{array}{ll}\text { Ag } & \text { Silver } \\ \text { Al } & \text { Aluminum } \\ \text { AINiCo } & \text { Aluminum-Nickel-Cobalt } \\ \text { ALARA } & \text { As Low As Reasonably Achievable } \\ \text { ALS } & \text { Analytical Laboratory System } \\ \text { APT } & \text { Accelerator Production of Tritium } \\ \text { Ar } & \text { Argon } \\ \text { ASTM } & \text { American Society of Testing and Materials } \\ \text { Ba } & \text { Barium } \\ \text { BCWS } & \text { Blanket Circulating Water System } \\ \text { BDAT } & \text { Best Demonstrated Available Technology } \\ \text { BHRPS } & \text { Blanket Heat Removal Primary System } \\ \text { BHRSS } & \text { Blanket Heat Removal Secondary System } \\ \text { BNL } & \text { Brookhaven National Laboratory } \\ \text { BOP } & \text { Balance of Plant } \\ \text { BPCS } & \text { Blanket Primary Cooling System } \\ \text { BRHRPS } & \text { Blanket Residual Heat Removal Primary System } \\ \text { BRHRSS } & \text { Blanket Residual Heat Removal Secondary System } \\ \text { BRPCS } & \text { Blanket Residual Primary Cooling System } \\ \text { BRSCS } & \text { Blanket Residual Secondary Cooling System } \\ \text { BSCS } & \text { Blanket Secondary Cooling System } \\ \text { C } & \text { Carbon } \\ { }^{\circ} \text { C } & \text { Celsius degree (unit of temperature) } \\ \text { CAM } & \text { Continuous Air Monitor } \\ \text { cC } & \text { Cubic centimeter } \\ \text { CCL } & \text { Couple-Cavity Linac } \\ \text { CCDTL } & \text { Coupled-Cavity Drift-Tube Linac } \\ \text { Cd } & \text { Cadmium } \\ \text { CERCLA } & \text { Comprehensive Environmental Responsibility, Compensation, } \\ \text { CFC } & \text { and Liability Act of 1981 } \\ \text { cfm } & \text { Chloroflurocarbon } \\ \text { CFR } & \text { Cubic Feet per Minute } \\ \text { Ci } & \text { Code of Federal Regulations } \\ \text { CIF } & \text { Curies } \\ \text { COBRA } & \text { Consolidated Incineration Facility (at SRS) } \\ \text { Cr } & \text { COmputerized (Radioactive Waste) Burial Record Analysis (at SRS) } \\ \text { CRM } & \text { Chromium } \\ & \text { Count Rate Meter } \\ & \end{array}$




\begin{tabular}{|c|c|}
\hline $\mathrm{Cu}$ & Copper \\
\hline $\mathrm{cw}$ & Continuous-Wave \\
\hline $\mathrm{D}$ & Deuterium Isotope of Hydrogen \\
\hline DBAs & Design Basis Accidents \\
\hline $\mathrm{D} \& \mathrm{D}$ & Decontamination \& Decommissioning \\
\hline DCF & Design Change Form \\
\hline DCS & Distributed Control System \\
\hline $\mathrm{D}_{2} \mathrm{O}$ & Deuterium Oxide (Heavy Water) \\
\hline DOE & Department of Energy \\
\hline DOP & Dioctyl phthalate (used to check HEPA filter efficiency) \\
\hline DOT & Department of Transportation \\
\hline $\mathrm{dpm}$ & Disintegrations per Minute \\
\hline DSSI & Diversified Scientific Services, Inc. (Oak Ridge, TN) \\
\hline DWPF & Defense Waste Processing Facility (Vitrification Facility at SRS) \\
\hline DWS & Domestic Water System \\
\hline EA & Exclusive Area \\
\hline EAV & E-Area Vaults (at SRS) \\
\hline EIS & Environmental Impact Statement \\
\hline EPA & Environmental Protection Agency \\
\hline $\mathrm{ES \& H}$ & Environmental, Safety \& Health \\
\hline ETF & Effluent Treatment Facility (Liquid Waste Treatment Facility at SRS) \\
\hline${ }^{\circ} \mathrm{F}$ & Fahrenheit degree (unit of temperature) \\
\hline FDD & Facility Design Description \\
\hline FFCA & Federal Facilities Compliance Act of 1992 \\
\hline FPS & Fire Protection System \\
\hline $\mathrm{ft}$ & foot or feet \\
\hline FY & Fiscal Year \\
\hline gpm & Gallons per Minute \\
\hline $\mathrm{H}$ & Hydrogen (Protium Isotope) \\
\hline $\mathrm{HE}$ & High-Energy \\
\hline${ }^{3} \mathrm{He}$ & Helium-3 \\
\hline $\mathrm{He}-3$ & Helium-3 \\
\hline${ }^{4} \mathrm{He}$ & Helium-4 \\
\hline HEBT & High-Energy Beam Transport \\
\hline HEPA & High Efficiency Particulate Air (Filter) \\
\hline $\mathrm{Hg}$ & Mercury \\
\hline HIC & High Integrity Container \\
\hline $\mathrm{HLW}$ & High-Level Waste \\
\hline HOM & High-Order-Mode \\
\hline HP\&EMS & Health Protection and Environmental Monitoring System \\
\hline HPN & High-Pressure Nitrogen \\
\hline
\end{tabular}




\begin{tabular}{|c|c|}
\hline HSS & ${ }^{3} \mathrm{He}$ Supply System \\
\hline HTO & Hydrogen Tritium Oxygen (Tritiated water) \\
\hline HVAC & Heating, Ventilation and Air Conditioning \\
\hline HW/MW DF & Hazardous Waste/Mixed Waste Disposal Facility (at SRS) \\
\hline ICS & Integrated Control System \\
\hline I. D. & Inside diameter \\
\hline IGS & Inert Gas System \\
\hline ILNTV & Intermediate Level Non-Tritium Vaults (part of SRS ILV) \\
\hline ILTV & Intermediate Level Tritium Vaults (part of SRS ILV) \\
\hline ILV & Intermediate Level Vaults (part of SRS E-Area Vaults) \\
\hline INEL & Idaho National Engineering Laboratory \\
\hline IOT & Inductive Output Tube \\
\hline ISS & Isotope Separation System \\
\hline ITP & In-Tank Precipitation (Liquid waste pre-treatment facility for DWPF) \\
\hline $\mathrm{JCW}$ & Job Control Waste \\
\hline${ }^{\circ} \mathrm{K}$ & Degree Kelvin \\
\hline KD-0 & Key Decision Zero \\
\hline $\mathrm{kg}$ & kilogram or 1000 gram (unit of mass) \\
\hline 1 & liter \\
\hline LANA & LAnthanum Nickel Aluminum (Metal Hydride Bed Fill Material) \\
\hline LANL & Los Alamos National Laboratory \\
\hline $\mathrm{lb}$ & pound \\
\hline LDR & Land Disposal Restriction \\
\hline LE & Low-Energy \\
\hline LiAl & Lithium Aluminum \\
\hline Linac & Linear Accelerator \\
\hline LLW & Low-Level Waste \\
\hline LOCA & Loss of Coolant Accident \\
\hline LPN & Low-Pressure Nitrogen \\
\hline LSS & Logistics Support System \\
\hline LTA & Lead Test Assembly \\
\hline$m^{3}$ & Cubic Meters \\
\hline Mg & Magnesium \\
\hline $\min$ & minute \\
\hline$\mu \mathrm{Ci} / \mathrm{cc}$ & Micro $\left(10^{-6}\right)$ Curies per cubic centimeter \\
\hline MCR & Main Control Room \\
\hline MLLW & Mixed Low-Level Waste \\
\hline mrem & millirem (absorbed radiation dose) \\
\hline MSB & Molecular Sieve Beds \\
\hline $\mathrm{Na}$ & Sodium \\
\hline NEPA & National Environmental Policy Act of 1969 \\
\hline
\end{tabular}




$\begin{array}{ll}\text { NESHAP } & \text { National Emission Standards for Hazardous Air Pollutants } \\ \text { Ni } & \text { Nickel } \\ \text { NPDES } & \text { National Pollutant Discharge Elimination System } \\ \text { NPR } & \text { New Production Reactor } \\ \text { NRC } & \text { Nuclear Regulatory Commission } \\ \text { NTS } & \text { Nevada Test Site } \\ \text { O.D. } & \text { Outside diameter } \\ \text { Pa } & \text { Psia } \\ \text { Pb } & \text { Lead } \\ \text { PC3 } & \text { Performance Category 3 } \\ \text { PCS } & \text { Process Confinement System } \\ \text { Pd } & \text { Palladium } \\ \text { PICs } & \text { Products of Incomplete Combustion } \\ \text { PPA } & \text { Property Protection Area } \\ \text { ppm } & \text { Parts per million } \\ \text { Psia } & \text { Pounds per square inch absolute } \\ \text { psig } & \text { Pounds per square inch gauge } \\ \text { PSS } & \text { Power Supply System } \\ \text { Pt } & \text { Platinum } \\ \text { PFR } & \text { Plug Flow Reverser } \\ \text { pCi/ml } & \text { Pico (10 }{ }^{-12} \text { ) Curies per milliliter } \\ \text { PNNL } & \text { Pacific Northwest National Laboratory } \\ \text { PPDA } & \text { Pollution Prevention Design Assessment } \\ \text { PPE } & \text { Personal Protective Equipment } \\ \text { PVC } & \text { Poly(vinyl chloride) } \\ \text { P-V-T-C } & \text { Pressure-Volume-Temperature-Composition (Tritium accountability } \\ & \text { method) } \\ \text { PWA } & \text { Process Waste Assessment } \\ \text { QA } & \text { Quality Assurance } \\ \text { RBOF } & \text { Receiving Basin for Off-site Fuel (at SRS) } \\ \text { RCRA } & \text { Resources Conservation and Recovery Act of 1976 } \\ \text { REPS } & \text { Radiation Exposure Protection System } \\ \text { RF } & \text { Radio Frequency } \\ \text { RFQ } & \text { Radio-Frequency Quadrupole } \\ \text { RHR } & \text { Residual Heat Removal } \\ \text { RHS } & \text { Remote-Handling System } \\ \text { REPS } & \text { Radiation Exposure Protection System } \\ \text { RMA } & \text { Radiological Materials Area } \\ \text { RMERC } & \text { Retorting or Roasting of Mercury } \\ \text { RMPS } & \text { Radiation Monitoring and Protection System } \\ \text { RTF } & \end{array}$


RWTS

$S \& S$

$\mathrm{SC}$

SCDHEC

SCE\&G

SDD

SEG

SHRPS

SNL-NM

SPCS

$\mathrm{SpG}$

SRPCS

SRCSC

SRS

SRTC

SSCS

SSS

$\mathrm{T}$

T/B

TBBS

T/B-GTS

TBD

TCAP

TCLP

TEF

TES

THRPS

THRSS

TOC

TPBAR

TRHRPS

TRHRSS

TRU

TRU Waste

TSCA

TSD

TSF

TSS

TSTA

U
Radioactive Waste Treatment System

Safeguards and Security

Superconducting

South Carolina Department of Health and Environmental Control

South Carolina Electric and Gas

System Design Description

Scientific Ecology Group (Oak Ridge, TN)

Shield Heat Removal Primary System

Sandia National Laboratories - New Mexico

Source Primary Cooling System

Specific Gravity

Source Residual Primary Cooling System

Source Residual Secondary Cooling System

Savannah River Site

Savannah River Technology Center

Source Secondary Cooling System

Sanitary Sewer System

Tritium Isotope of Hydrogen

Target/Blanket

Target/Blanket Beamtrip System

Target/Blanket Gas Transport Subsystem

To Be Determined

Thermal Cycling Absorption Process (Method for hydrogen isotopic separation)

Toxicity Characteristic Leaching Procedure (e.g., EPA Method 1311)

Tritium Extraction Facility

Tritium Extraction System

Tungsten Heat Removal Primary System

Tungsten Heat Removal Secondary System

Total Organic Carbon

Tritium Producing Burnable Absorber Rod

Tungsten Residual Heat Removal Primary System

Tungsten Residual Heat Removal Secondary System

Transuranic (e.g. Pu)

Transuranic Waste

Toxic Substances Control Act (40CFR761)

Treatment, Storage, and Disposal (waste management facility)

Tritium Separation Facility

Tritium Storage System

Tritium Systems Test Assembly (at LANL)

Uranium 


$\begin{array}{ll}\text { UPS } & \text { Uninterruptible Power Supply } \\ \text { VOC } & \text { Volatile Organic Compounds } \\ \text { vol } & \text { Volume } \\ \text { WAC } & \text { Waste Acceptance Criteria } \\ \text { WCWS } & \text { Window Circulating Cooling System } \\ \text { WECS } & \text { Window and Expander Cooling System } \\ \text { WERF } & \text { Waste Experimental Reduction Facility (at INEL) } \\ \text { WGTCS } & \text { Waste Gas Tritium Clean-up System } \\ \text { WHRPS } & \text { Window Heat Removal Primary System } \\ \text { WHRSS } & \text { Window Heat Removal Secondary System } \\ \text { WIPP } & \text { Waste Isolation Pilot Plant (TRU Waste Disposal Facility in New } \\ & \text { Mexico) } \\ \text { WITS } & \text { Waste Information Tracking System (at SRS) } \\ \text { WM } & \text { Waste Management } \\ \text { WPCS } & \text { Window Primary Cooling System } \\ \text { WRAP } & \text { Waste Receiving and Processing Facilities (at Hanford) } \\ \text { WSCS } & \text { Window Secondary Cooling System } \\ \text { WSRC } & \text { Westinghouse Savannah River Company } \\ \text { WTS } & \text { Water Treatment System } \\ \text { Z-Bed } & \text { Zeolite Bed }\end{array}$




\section{Table of Contents}

1. Introduction 1 *

2. Purpose 1

3. Background 2

4. Methodology 2

4.1 Process Definition 3

4.2 Process Characterization 3

4.3 Waste Minimization / Pollution Prevention Assessment 4

4.4 Waste Treatment and Disposal 4

5. Summary 5

5.1 Process Waste Streams 5

$\begin{array}{lll}5.2 \text { Contaminant Sources } & 7\end{array}$

$\begin{array}{ll}5.2 .1 \quad \text { Irradiated Modules } & 7\end{array}$

$\begin{array}{lll}5.2 .2 & \text { Accelerator Wastes } & 10\end{array}$

5.2.3 Tritium Separation Facility 11

5.3 Waste Treatment and Disposal 12

5.3.1 Waste Treatment 12

$\begin{array}{lll}\text { 5.3.2 Waste Disposal } & 14\end{array}$

5.4 PPOA Critical Assumptions $\quad 14$

5.5 Challenging Waste Streams and Waste Management Issues $\quad 15$

$\begin{array}{lll}\text { 5.5.1 Spent Modules } & 15\end{array}$

5.5.2 Radioactive Liquid Waste 16

5.5.3 Radionuclide Permeation and Quantification 16

5.5.4 Waste Classification/Greater-Than-Class C 17 
6.0 Waste Minimization/Pollution Prevention (WMin/PP) 18

6.1 Overall APT Waste Management and WMin/PP Strategy 20

6.2 APT Waste Streams 21

6.3 APT Waste Types 21

6.4 Waste Packaging 22

$\begin{array}{lll}7.0 & \text { Conclusions } & 23\end{array}$

8.0 References $\quad 24$

Appendix A, APT Processes and Operations A-1

A1. Accelerator Systems A-3

A2. Target/Blanket Systems A-6

A3. Tritium Separation Facility A-16

A4. Balance of Plant Facilities A-24

A5. Site and Buildings A-42

Appendix B, APT Hazardous, Low-Level and Mixed Waste Streams $\quad$ B-1

B1. Job Control Waste B-5

B1a. Nonhazardous Solvent $\quad$ B-8

B2. Job Control Waste (Mixed Low Level Waste) B-9

B3. Nonhazardous Process Equipment B-10

B3a. Uranium/Magnesium Beds $\quad$ B-12

B3b. Hydride/Catalyst/Zeolite Beds $\quad$ B-14

$\begin{array}{ll}\text { B3c. Ion Exchange Resins } & \text { B-17 }\end{array}$

B3d. Palladium/Electrolysis Membrane B-19

$\begin{array}{ll}\text { B3e. HEPA Filters } & \text { B-20 }\end{array}$

B3f. SAES St909 Beds B-21

B3g. Spallation Metal Filter Assemblies B-22

B3h. Accelerator Components Containing Niobum B-23 
B4. Palladium-Silver Permeator Waste Process Equipment

B4a Silver Plated Waste Fittings

B-26

B5. Mixed and Hazardous Waste Oil/Solvent

B-28

B6. Mixed Waste Solvent Rags

B-30

B7. Analytical Laboratory/Rad Con Chemicals

B-31

B8. Teledyne Oxygen Sensor Micro-Fuel Cells

B-34

B9. Mixed Waste Lead

B-36

B10. Nonhazardous Radioactive Oil

B-43

B10a. Glovebox Bubbler Fluid

B-45

B11. Radioactive Light Water and Aqueous Solutions

B12. Radioactive Heavy Water Waste

B13. Non-Radioactive Process Wastewater

B14. Sanitary and Industrial Waste

B15. Tungsten

B-53

B16. Window Modules

B-59

B17. Steel Shielding

B18. Aluminum

B-63

B19. Batteries

B20. APT Non-Radioactive Air Emissions

B21. APT Radioactive Air Emissions

B-68

B22. Job Control Waste (LiAl Extraction)

B-71

B23. Spent LiAl Extraction

B-73

B24. Nonhazardous Process Equipment (LiAl Extraction)

B-74

B24a. Failed Furnace Components (LiAl Extraction)

B-75

B24b. HEPA Filters (LiAl Extraction)

B-76 
Appendix C, Treatment and Disposal of APT Waste

C-1

C1. APT Waste Disposition

C-3

C1.1 Low-Level Waste

C-3

C1.2 Mixed Low-Level Waste

C-4

C1.3 Hazardous Waste

C-5

C2. Existing and Planned SRS Waste Treatment Facilities

C-5

C2.1 E-Area Vaults

C-5

C2.2 Consolidated Incineration Facility

C-6

C2.3 Hazardous/Mixed Waste Storage Pads/Buildings

C-7

C2.4 Sanitary Landfill

C-8

C2.5 Sanitary Sewage Treatment Facility

C-8

C2.6 Hazardous Waste/Mixed Waste Disposal Facility

C-8

C2.7 Prohibited Wastes

C-8

C3. Other DOE and Commercial Waste Treatment Facilities

C-9

C3.1 Hanford

C-12

C3.2 Nevada Test Site

C-12

C3.3 Scientific Ecology Group (SEG)

C-12

C3.4 Diversified Scientific Services, Inc. (DSSI)

C-14

C3.5 Envirocare

C-14

C3.6 GTS Duratek

C-14

C4. Treatment Technologies

C4.1 Compaction

C-15

C4.2 Thermal Desorption

C-15

C4.3 Incineration

C-16

C4.4 Stabilization

C-17

C4.5 Vitrification

C-17 


\section{C4.6 Encapsulation}

C-18

C4.7 Metals Recovery

C-18

Appendix D, Waste Stream Inventory by Waste Type

D-1

Appendix E, Waste Stream Inventory - EIS Format

E-1

Appendix F, Waste Stream Inventory by Waste Treatment Category

F-1

Appendix G, EPA Hazardous Waste Codes with Subcategories

G-1

Appendix H, APT Decommissioning and Construction Wastes

H-1 


\section{List of Tables}

$\begin{array}{rlc}\text { Table 1 } & \text { Estimated Annual Waste Generation Rates for APT } & 6 \\ \text { Table 2 } & \text { Treatment/Disposal Options for APT Waste } & 13 \\ \text { Table 3 } & \text { NRC Greater-Than-Class C Radionuclide Limits } & 18 \\ \text { Table B 1 } & \text { SRS FY97-98 Tritium Waste Forecast } & \text { B-7 } \\ \text { Table B2 } & \text { Tier II Hazardous Chemical Inventory } & \text { B-31 } \\ \text { Table C1 } & \text { Existing and Planned DOE Waste Treatment Facilities } & \\ & \text { Relevant for APT Waste } & \text { C-10 } \\ \text { Table G1 } & \text { EPA Hazardous Waste Indexes } & \text { G-2 } \\ \text { Table H1 } & \text { APT Facility Contamination Index and Decommissioning H-2 } \\ \text { Table H2 } & \text { Facility and Infrastructure Decommissioning Wastes } & \text { H-4 } \\ \text { Table H3 } & \text { APT Construction Waste Estimates } & \text { H-7 }\end{array}$

\section{List of Figures}

Figure B-1 APT Radioactive Liquid Waste Flow Diagram

Figure B-2 APT Non-Radioactive Process Wastewater Flow Diagram B-51

Figure C-1 APT Waste Management Facilities C-20 
[This Page Left Intentionally Blank] 


\section{Introduction}

The mission of the Accelerator Production of Tritium (APT) Project is to provide a reliable supply of tritium to maintain the United States' nuclear defense capability. Tritium is essential for our weapons to function, but because it decays at a rate of $5.5 \%$ per year, the supply must be continually replenished. Since the last production reactor stopped operating in 1988, tritium has been recovered from dismantled nuclear weapons. This process is possible only as long as sufficient weapons are being retired. It will not work indefinitely, requiring the United States Department of Energy (DOE) to bring a new tritium production capability on line in the 2005 2007 time frame, as specified in the 1996 Nuclear Weapons Stockpile Memorandum. To accomplish this mission, the APT plant will use a high-power proton linear accelerator to generate neutrons which will in turn be thermalized and captured in ${ }^{3} \mathrm{He}$ to produce tritium. The tritium will be continuously separated and purified to produce War Reserve grade tritium.

The Conceptual Design Report (CDR) for the APT plant was prepared and documented by a multilaboratory and industry team that included Los Alamos, Sandia, Brookhaven, and Livermore National Laboratories; the Westinghouse Savannah River Company; the APT Prime Contractor, Burns and Roe; and supporting subcontractors Northrop Grumman and Babcox and Wilcox.

\section{Purpose}

The DOE has made a commitment for the Accelerator Production Of Tritium project to comply with all applicable environmental regulatory requirements. In this respect, it is important to consider and design all tritium production and extraction processing alternatives so they comply with these requirements. The management of waste is an integral part of this activity and it is therefore necessary to estimate the quantities and specific wastes that will be generated by the APT. A thorough assessment of waste streams includes waste characterization, quantification, and the identification of treatment and disposal options. This Pollution Prevention Design Assessment (PPDA) provides waste stream characterization and quantification information required to meet the waste generation and waste minimization requirements defined in 40 CFR 268 (Land Disposal Restrictions), 40 CFR 260-5, the SRS Site Treatment Plan, DOE Orders 435.1, 430.1, and the 5400.xx and 5480.xx series. It is based on the format of a PWA developed in 1994 by Sandia National Laboratories-New Mexico (SNL-NM) for the APT (Ref. 3) and is intended to provide data for the APT Environmental Impact Statement (EIS) such as in Ref. 7-8. (Note: The periodic Process Waste Assessments conducted by Operating Facilities at SRS are being renamed Pollution Prevention Design Assessments). 
The management and ultimate disposal of waste is a costly and complicated activity involving established internal procedures, permitting, and other regulatory issues. The costs and lead times associated with these issues should be estimated and considered along with other design and engineering costs. This PPDA provides data for cost-benefit analysis of the potential environmental impact of the APT, is an integral part of pollution prevention/waste minimization, and is required by DOE for any activity generating radioactive, hazardous, and mixed wastes. It will also better position the APT to meet future requirements, since it is anticipated that regulatory and other requirements will continue to become more restrictive and demanding.

A PPDA is also essential for the evaluation of the design or technology options proposed for the APT. A key factor in module design requirements and other design feature selections is the assessment of waste streams and quantities produced. Waste stream analysis will demonstrate whether advantages in terms of waste volumes and characteristics may result from the use of a certain technology and/or design features.

\section{Background}

The DOE is responsible for research, development, and testing of nuclear weapons for the Department of Defense. These responsibilities include production of certain critical materials required for the weapons. One such material is tritium, a gaseous isotope of hydrogen used to enhance the explosive power of nuclear warheads. Tritium is radioactive, and about 5.5 percent is lost each year through natural decay (12.3 years half-life). Because of this loss, existing weapons must be re-supplied periodically with tritium in order to maintain their effectiveness.

In the 1950's, the DOE began producing tritium in nuclear reactors located at the Savannah River Site near Aiken, South Carolina. Concerns about operational safety led DOE to shut down these reactors in 1988. Two primary alternatives are now being considered for meeting future requirements for tritium production: 1) Accelerator Production of Tritium, and 2) Commercial Light Water Reactor. The proposed APT is to be built at SRS. It has some attributes of a nuclear reactor facility, e.g., handling of irradiated modules with significant radiation levels and decay heat. However, the APT is not expected to introduce or process materials that could lead to criticality issues and there will be no generation of high-level waste (HLW) or Transuranic waste (TRU).

\section{Methodology}

This PPDA is concerned with characterization of all waste streams generated during normal operation of the APT to produce, extract and purify tritium from the Target/Blanket building. Because the APT facility design is in the conceptual design phase, waste streams generated at the 
end of the life of the facility during the decontamination and decommissioning (D\&D) and wastes from accidents are not examined in depth. Sanitary sewage and wastewater are generated based on APT staffing estimates. Qualitative and quantitative assessments were performed for all other process-specific waste streams, and non-process activities such as maintenance and repair. The envelope examined includes all processing steps in the APT.

There are four parts to this PPDA: process definition, process characterization, preliminary waste minimization pollution prevention assessments (a 5 part process discussed in section 6.0), waste treatment and disposal. "Process" is used broadly here to include any operation generating a waste or pollutant, or uses a hazardous or radioactive material. Current implementation of pollution prevention design opportunities and the documentation of these actions are in Appendix B for each waste stream.

\subsection{Process Definition}

Process definition briefly describes the overall operations and the specific processes or operations that consume or generate sanitary, hazardous and/or radioactive materials or wastes. Each of these processes is discussed in Appendix A, APT Processes and Operations. A simplified process schematic for the APT is also given in Appendix A. For this discussion, APT processes were organized into five major systems:

- A linear accelerator that produces and directs an energetic proton beam to a tritiumproducing target/blanket.

- A target/blanket that produces neutrons by proton spallation of tungsten and lead and generates tritium through the ${ }^{3} \mathrm{He}(\mathrm{n}, \mathrm{T}) \mathrm{H}$ reaction.

- A tritium separation system that extracts tritium from the ${ }^{3} \mathrm{He}$ and prepares it for shipment to the Savannah River Tritium Facility.

- A balance of plant complex to house the above systems and to support their integrated operation, and

- Site and buildings necessary to support the operational and maintenance needs of the plant.

\subsection{Process Characterization}

Process characterization collects information about the quantity and nature of the hazardous and/or radioactive materials used in APT processes to include the wastes and other pollutants generated. This information was obtained from a variety of sources such as experience of existing SRS and LANL tritium facilities, projected levels of production activities, and engineering estimates. Most APT processes are still in the conceptual design stage and the information needed for a complete characterization is not yet available. Several wastes identified are not the result of a process, but rather are from site-wide maintenance of process equipment or from failure of process equipment and components through usage or exposure to harsh 
environments. Wastes from all processes were grouped into waste streams with similar characteristics and modes of generation.

Appendix B provides the following information for each of thirty six identified APT waste streams:

Type: Identifies a solid waste stream (e.g., hazardous waste, low-level radioactive waste, intermediate-level waste or mixed low-level waste). Intermediate-level waste is a subset of lowlevel waste; it is used to designate low-level wastes that emit greater than $200 \mathrm{mRad} / \mathrm{hr}$ closed window reading at $5 \mathrm{~cm}$ from the container surface. Radioactive and non-radioactive liquid waste streams are also identified. No high-level or transuranic waste is expected to be generated by the APT.

Description: Waste stream physical matrix, chemical composition, RCRA components and hazardous waste codes present, and anticipated radioactive isotopes and activity levels.

Generation: A description of the processes or activities that generate the waste stream.

Handling and Packaging A description of current or recommended handling and packaging techniques for the waste stream.

Annual Quantities: Estimated annual generation rates in both mass and volume. Quantities are based on experience of DOE facilities with similar operations or using similar components, assumed levels of production activities and engineering judgment.

Treatment Options: Lists possible treatment technologies for LLRW or MLLW. Descriptions of the listed treatment technologies are given in Appendix C. It is assumed that hazardous waste which cannot be incinerated in the Consolidated Incineration Facility (CIF) will be packaged for treatment and/or disposal at a DOE-approved DOE or commercial waste management facility. One notable exception is corrosive-only hazardous waste that must be treated by the waste generator before disposal.

Comments: Provides additional information pertinent to understanding the nature of the waste stream or its treatment, which do not fit in with other categories.

\subsection{Waste Minimization/Pollution Prevention Assessment}

The Waste Minimization / Pollution Prevention (WMin/PP) assessment identifies and evaluates various alternatives for reducing or eliminating the waste stream, or for eliminating either the hazardous or radioactive component in the mixed low-level waste. The APT WMin/PP detailed strategy and the 5 step process for WMin/PP is in section 6.0. A detailed understanding of how 
hazardous materials are used and wastes are generated in the process is critical to the success of this effort. Waste minimization is also addressed under a separate sub-heading for each waste stream listed in Appendix B.

\subsection{Waste Treatment and Disposal}

APT wastes will need to be managed for treatment and disposal according to waste type; i.e., sanitary, hazardous, low-level, or mixed low-level waste, in accordance with the requirements of DOE Order 5820.2A and other applicable DOE Orders. At SRS, operating divisions must provide a facility Waste Certification Plan to the Solid Waste Department for approval. The Waste Certification Plan and individual waste stream characterization plans must be approved, and the Waste Management Facility Waste Acceptance Criteria must be met before waste can be shipped to the Solid Waste Management Division for treatment, storage and/or disposal.

Waste treatment options existing or expected to be available by the time the APT facility is built, are listed for each waste stream in Appendix B. If more than one treatment method is feasible for a particular waste stream, no attempt is made to prioritize or recommend specific treatments; such recommendations would necessarily be based on cost-benefit analyses, trade studies and risk assessments that would be performed at a later stage of design development. If a treatment generates secondary waste that also requires treatment, this is discussed in the context of the primary APT waste stream and the secondary waste is not listed as a separate waste stream.

SRS, DOE, and commercial low-level and mixed waste treatment/disposal facilities are presented in Appendix C, Treatment and Disposal of APT Wastes. Brief descriptions of treatment technologies currently available or expected to be available by the time APT is built are presented in Appendix C.

\section{Summary}

This PPDA was developed based on pre-conceptual and conceptual design information. The anticipated waste streams identified and projected quantities reported here reflect design data in the APT Pre-Conceptual Design Package of June 28, 1996, various APT Design Documents, the Conceptual Design Report of April 15, 1997, Cinder 90 physics calculations, conceptualized modes of operation, assumed levels of production activities, and engineering assessment. Development of this PPDA will be an iterative process. The waste stream information should be refined as the design progresses, preferred technologies are selected, operational uncertainties and assumptions are refined and characterizations of contaminant sources are improved. The APT PPDA will be revised and reissued as required in the design/construction/operations process. 


\subsection{Process Waste Streams}

Radioactive waste in the APT is generated from the acceleration of the proton beam, the production of tritium via spallation physics and neutron capture in $\mathrm{He}-3$ within the target/blanket modules and the separation and purification of tritium in the Tritium Separation Facility. The accelerator wastes are primarily materials activated by either direct exposure to the proton beam or exposure to stray energy in the beam halo. The majority of the waste streams will be produced within the target/blanket cavity; including the tungsten targets, the lead and aluminum components of the blankets, decouplers and reflectors, and the light and heavy water cooling streams. Many of these will become highly activated and contain a wide array of radioactive isotopes. They will also be contaminated with tritium. The activated lead components will be mixed wastes. The process for separating the tritium from the recirculating $\mathrm{He}-3$ gas loop will generate waste streams contaminated primarily with tritium.

Wastes are generated as part of the production process, decontamination process, analytical activities, and operation of supporting facilities. They are also generated incidentally through failed equipment, routine maintenance and due to off-normal events.

Thirty-six APT waste streams have been identified and are described in Appendix B. Estimates of the annual uncompacted, containerized waste generation rates by waste type, mass and volume are summarized from Appendix B and presented in Table 1. A similar table has been developed for the Environmental Impact Statement (EIS) Input Submittal report. In addition to waste classification according to waste type (low-level, hazardous or mixed), data in the EIS are broken out by waste source; i.e., tungsten neutron source, window modules, lead modules, etc. A summary of waste stream data by waste type is provided in Appendix D and EIS summary data are presented in Appendix E.

Table 1. Estimated Annual Waste Generation Rates for the APT Note: Based on Superconducting Option and $\mathrm{He}^{3}$ Target

\begin{tabular}{|l|c|c|}
\hline \multicolumn{1}{|c|}{ Waste Type } & $\begin{array}{c}\text { Mass } \\
\mathbf{k g} / \mathbf{y r}\end{array}$ & $\begin{array}{c}\text { Volume } \\
\mathbf{m} \text { '/yr }\end{array}$ \\
\hline \hline Transuranic Waste & 0 & 0 \\
\hline High-Level Waste & 0 & 0 \\
\hline Low-Level Radioactive Waste & 669,000 & 1,370 \\
\hline Hazardous Waste & 1,760 & 3 \\
\hline Mixed Low-level Waste & 44,000 & 13 \\
\hline Radioactive Liquid Streams & - & 524 \\
\hline APT Liquid Wastestreams & - & $3,500,000$ \\
\hline Liquid Sanitary Sewage & - & 15,500 \\
\hline
\end{tabular}




\begin{tabular}{|l|l|l|}
\hline Solid Sanitary/Industrial & $6,000,000$ & 12,000 \\
\hline
\end{tabular}

The numbers given here should not be considered the total wastes for APT; they are the totals for waste streams that can be quantified at this time. Appendix B has several waste streams where the quantities cannot be accurately determined at the current design stage, and the totals presented do not include a complete contingency volume for these streams.

Job control waste, primarily personal protection equipment (PPE), from the APT is estimated at $1000 \mathrm{~m}^{3} / \mathrm{yr}$, with the majority of this total assumed to result from target/blanket building activities and from tritium processing. Lower volumes will be generated from the beam stop building and the accelerator tunnel. However, with a high degree of remote-handled operations expected in the APT and use of confinement systems, there is uncertainty in the total volume. Half of the job control wastes are assumed to be incinerable at the Consolidated Incinerator Facility (CIF). The total estimate for all job control waste streams is $\sim 130,000 \mathrm{~kg} / \mathrm{yr}$ or $\sim 19 \%$ of the total weight and $\sim 73 \%$ of the total volume of radioactive waste generated by the APT. All $\mathrm{JCW}$ volumes are for uncompacted, containerized waste.

Job control waste streams for the APT are reduced from current SRS Tritium Facilities baseline forecasts for similar activities based on the expectation that waste minimization initiatives will reduce waste generated by APT start-up by 50\% for comparable activities and on over ten years' of operating experience at the LANL Tritium Systems Test Assembly (TSTA). The TSTA is a tritium processing and cryogenic distillation purification facility which has processed approximately $100 \mathrm{~kg}$ of tritium during this period (averaging $10 \mathrm{~kg} / \mathrm{yr}$ ) using triple containment designs. During this ten-year period of contimuous facility operation.

- TSTA has never had a spill.

- Glovebox gloves have not needed to be changed.

- Approximately ten pairs of latex gloves have been used.

- Approximately $100 \mathrm{~kg}$ of plastic sheeting has been used.

- Approximately $45 \mathrm{~kg} / y \mathrm{r}$ of plastic bags are used.

- Plastic shoe covers are used an average of less than once a year.

- Plastic suits and air hoses have never been used.

The APT will be designed to minimize the need for "plastic suit work" and the resulting wastes. Double or triple containment systems such as that used at TSTA or the 233-H RTF at SRS will allow for many maintenance activities to be performed in glove boxes and are expected to minimize waste generation.

\subsection{Contaminant Sources}


The following sections discuss the primary sources of the radioactive and hazardous contaminants found in APT wastes. These sources include the irradiated target/blanket modules, activated materials from the accelerator and the tritium separation activities.

\subsubsection{Irradiated Modules}

The target/blanket modules are the location of tritium production within the APT. The targets are bombarded with the high energy proton beam from the accelerator and by the spallation process neutrons are produced and thermalized for capture by the ${ }^{3} \mathrm{He}$ gas circulating through the blanket to produce tritium. The modules are located within a concrete cavity vessel approximately $20 \mathrm{~m}^{2}$. Inside the cavity is a large vacuum vessel housing the target/blanket modules. Outside of the vessel is sufficient steel and concrete shielding to allow personnel access to adjacent rooms while the target/blanket is in operation. The target/blanket vessel is linked to the accelerator through the High Energy Beam Transport and Beam Expander systems.

All of the components within the vessel are "modular" in design, allowing for replacement and maintenance. The major components are the beam entrance window, the tungsten neutron source, the upstream blanket region, the neutron decoupler, the lateral blanket, the reflector, the downstream blanket, the shield inside the vessel, upper cavity internals, gas-handing systems, and the cavity vessel itself. A short description of each region and the modular arrangement is provided below.

- Proton Beam Window

The beam entrance window, a double-wall Inconel structure, separates the high-vacuum environment of the beam expander from the rough-vacuum environment of the target/blanket cavity vessel. The $100 \mathrm{~mA}, 1.7 \mathrm{GeV}$ proton beam exiting the accelerator passes through the window, suffering only a slight degradation $(\sim 4 \mathrm{MeV}$, or $0.2 \%)$ in energy. At the window position the beam spot size is $13.4 \mathrm{~cm}$ wide by $144 \mathrm{~cm}$ high. By the time it reaches the tungsten neutron source (described below) $2 \mathrm{~m}$ downstream of the window, the beam spot has expanded to $16 \mathrm{~cm}$ wide by $160 \mathrm{~cm}$ high. The heat deposited in the window structure is less than $1 \mathrm{MW}$ and is removed by a low-pressure light-water coolant.

- Tungsten Neutron Source

After passing through the beam entrance window, the proton beam strikes a centrally located tungsten neutron source that is heavy-water cooled. The function of the tungsten neutron source is to efficiently use the high-energy proton beam to produce a primary source of neutrons and high-energy particles. The neutron source consists of small tungsten rods contained in horizontal stainless steel tubes. These horizontal tubes are manifolded into larger diameter vertical inlet and outlet pipes, which provide a coolant flow of heavy water at moderate pressure. The horizontal and vertical tubes make up a structure called a ladder. 
The tungsten neutron source consists of 13 such ladders arranged in two modules, one containing six ladders and the other seven.

- Decoupler

High-energy particles scattered out of the tungsten neutron source pass through a decoupler region and into the blanket modules that surround the tungsten neutron source. The decoupler region consists of several rows of tightly packed aluminum tubes containing ${ }^{3} \mathrm{He}$ with light-water coolant flowing outside the tubes, under moderate pressure. The ${ }^{3} \mathrm{He}$ in this region, preferentially absorbs the low energy neutrons that scatter from the lead blanket, maximizing neutron absorptions in ${ }^{3} \mathrm{He}$ and minimizing neutron absorptions in tungsten. A major fraction of the total tritium production occurs in the decoupler.

- Blanket

A blanket region surrounds the tungsten neutron source and decoupler. It is approximately $120 \mathrm{~cm}$ thick and $350 \mathrm{~cm}$ high. This region contains lead, ${ }^{3} \mathrm{He}$ gas, aluminum, and light-water coolant in various fractions that are tailored to meet thermal hydraulic safety margins while maximizing the tritium production. The lead in this region provides an additional source of neutrons from additional spallation and $(\mathrm{n}, \mathrm{xn})$ reactions. Neutrons are moderated to low energy by collisions in the lead and light water, and are captured in the ${ }^{3} \mathrm{He}$ gas to produce tritium. The blanket lead is cast into cruciform shaped aluminum tubes to form rods. The ${ }^{3} \mathrm{He}$ is contained in blind circular aluminum tubes that are manifolded together at the top and sealed off at the bottom. The rods and tubes are assembled into aluminum housings, which forms the pressure boundary for the light-water coolant. Tritium produced in the ${ }^{3} \mathrm{He}$ diffuses upward to the manifold, where it is removed by a sweep gas flow. The ${ }^{3} \mathrm{He}$ and tritium mixture is continuously transported to a tritium separation facility located in close proximity to the target/blanket stations.

- Reflector

The blanket is surrounded by a reflector region which reduces the overall neutron leakage from the blanket and enhances the tritium production. This region consists of an aluminum housing through which light water is circulated to serve as coolant and reflector material, and blind aluminum tubes that contain ${ }^{3} \mathrm{He}$.

- Upstream Blanket Region

Between the window and the tungsten neutron source is the upstream blanket region. The primary function of the upstream blanket is to provide a channel through which the neutron beam passes while capturing neutrons backstreaming from the target. Additionally, it shields the upstream portion of the cavity vessel, reducing its activation. This $2 \mathrm{~m}$ long region is composed of a decoupler, a lead blanket, and reflector, all light water cooled.

- Dowństream Blanket Region 
Located directly behind the tungsten neutron source is the downstream blanket region. It consists of a decoupler region followed by five rows of blanket, similar in design to the lateral decoupler and blanket designs.

- Shield

Iron shielding surrounds the blanket and reflector to minimize activation of the yessel and external structures and to protect workers. In addition, iron shields attach to the top of the target/blanket region facilitate connection and disconnection of coolant and gas lines during module replacement operations. The power density in the first 100 to $200 \mathrm{~cm}$ of shielding that surrounds the blanket and reflector is sufficiently high to require some active cooling. This is done with light-water cooling panels that are attached to the shield blocks. Outside this region the power density is sufficiently low that active water cooling is not required.

- Upper Cavity Internal Structures

The upper cavity houses a number of structures that provide all of the utilities required to operate the target/blanket components. This includes headers for heavy water and light water coolant, connecting piping from the headers to the modules, ${ }^{3} \mathrm{He}$ gas line connections, and instrumentation. Also included are the cavity flood inlet pipes and the coolant extraction suction lines.

- Gas Handling Subsystems

Helium-3 gas contained in the blind aluminum tubes within the decoupler, blanket and reflector produces tritium through neutron absorption. Tritium diffuses through the static gas to headers that connect the tubes within a module. A continuous flow of gas through the headers is maintained by the gas handling system. This system transports the ${ }^{3} \mathrm{He}$ gas mixture to the tritium separation facility. All gas lines are enclosed in a secondary confinement between the modules and the tritium separation glove boxes. Gas from the modules contains a mixture of ${ }^{3} \mathrm{He}$ with tritium, other hydrogen isotopes, and impurities. After extraction of the hydrogen isotopes and the removal of impurities, clean ${ }^{3} \mathrm{He}$ is returned to the Target/Blanket System modules.

A second gas subsystem within the gas handling systems controls the cavity atmosphere during operation. This system consists of a pumping system to evacuate the air from the vessel to a pressure of 1 torr along with gas sensors and controls. The evacuated gasses will be continuously monitored for indications of water ingress, ${ }^{3} \mathrm{He}$, hydrogen or tritium gas. Controls will direct the gas flows through HEPA filters, gas clean up systems, a ${ }^{3} \mathrm{He}$ recovery system or to the stack.

The third gas system is a low pressure ${ }^{3} \mathrm{He}$ recovery system that collects the gas from numerous areas in the target blanket facility and transport the gas back to the Tritium Separation Facility. The recovery system collects gases from the cavity vessel, the coolant 
loops, the vacuum line jackets and glove boxes in the target blanket facility. These gases which may have impurities can then be processed to separate the ${ }^{3} \mathrm{He}$ and hydrogen isotopes from the contaminants, to maintain a clean gas stream to TSF.

- Cavity Vessel System

Encasing the target/blanket assembly is a sealed stainless steel pressure vessel. The vessel is of cylindrical shape with a removable head structure for access and extraction of internal components. As a pressure boundary, it provides a vacuum atmosphere for the beam to pass through, minimizing air activation. It is also the confinement boundary and radionuclide barrier in the event of an internal coolant leak or a ${ }^{3} \mathrm{He}$ gas line leak. In the event of a cavity flood condition, the vessel serves as the pressure boundary for the flood coolant.

A modular arrangement has been chosen for the target/blanket assembly. Modules are formed by the mechanical and hydraulic coupling of several components. For example, the tungsten neutron source is combined with the decoupler and the first blanket region into two modules. A total of 22 modules form the target/blanket assembly. Each module is designed to be removed and replaced separately. Due to radiation damage, the window and neutron source modules are expected to require replacement every one to three years. The expected lifetime of the inner blanket modules is one to five years, the intermediate blanket lead modules 10 to 20 years, and the outer blanket lead and reflector/shield modules over 40 years

\subsubsection{Accelerator Wastes}

In the process of accelerating the proton beam and directing to the target/blanket cavity, some components or materials in the accelerator section of the APT will become radioactive through activation interaction with the high energy protons. This may be caused by direct impact by the beam or from stray protons caused by beam spill. Waste streams from the accelerator will primarily be failed/spent components and equipment consisting of activated metal solids. These will be classified as LLRW. The wastes should not contain tritium or hazardous constituents. The radiation level of these wastes will be dependent on the amount of the beam to which they are exposed, the energy of the beam and the length of time they are in place.

Components with direct interaction with the beam are:

- Harps

- Collimators

- Ambient air in the tunnel

Components susceptible to activation by beam spill are:

- Magnets 
- CCDTL

\subsubsection{Tritium Separation Facility}

The primary function of the TSF is to extract hydrogen isotopes from the Target/Blanket Gas Transport Subsystem(T/B-GTS) and isotopically separate tritium from the other hydrogen isotopes. The tritium is analyzed and packaged for shipment to the SRS Tritium Facilities. The majority of the waste streams will be failed/spent equipment contaminated with tritium. The large majority of these will be LLRW, although some streams will be mixed waste because of the use of silver in coating or brazing of the components. An overview of the system's general functions is given below.

\section{Tritium Extraction System}

The Tritium Extraction System (TES) separates hydrogen isotopes from the ${ }^{3} \mathrm{He}$ stream received from the Target/Blanket Gas Transport Subsystem (T/B-GTS). A total of five tritium extraction systems will be contained within the TSF.

\section{Isotope Separation System}

During the normal course of operation of the APT facility, a mixture of tritium and protium, along with a small amount of deuterium, is produced in the T/B System and extracted from ${ }^{3} \mathrm{He}$ stream in the TES. The primary function of the Isotope Separation System (ISS) is to separate a high-purity tritium stream from this isotopic mixture. A secondary function is to reduce the residual tritium concentration in the protium waste stream to a level where it can be sent to the facility stack without further processing. These missions are accomplished using a cryogenic distillation system. Two identical distillation systems, connected in parallel and each capable of individually satisfying the performance criteria, will be installed. Each system consists of two or more sequential columns in combination with four catalytic equilibrators.

\section{Waste Gas Tritium Clean-Up System}

The Waste Gas Tritium Clean-Up System (WGTCS) processes tritium-contaminated nitrogen streams to remove hydrogen isotopes and recover ${ }^{3} \mathrm{He}$ prior to sending the nitrogen to the HVAC exhaust system. Tritium-contaminated nitrogen is generated from the nitrogen flushes of process lines, airlocks and transfer containers. The hydrogen isotopes are removed from the gas stream using a series of metal hydride storage beds. The nitrogen stream at the outlet of the storage beds is sent to the TSF HVAC exhaust system if the residual tritium concentration is below the acceptable limit. If the tritium activity is above this limit, the nitrogen is recirculated 
through the WGTCS until the activity level is below the limit before the nitrogen is sent to the stack.

\section{Tritium Storage System}

The Tritium Storage System (TSS) consists of storage tanks, for storing hydrogen isotopes and ${ }^{3} \mathrm{He}$, and metal hydride beds, for storing hydrogen isotopes. Storage tanks will vary in size, depending on service function, and the beds will be designed for a 20 -mole tritium storage capacity. The tritium stored on the beds can be recovered as a gas by heating the beds to a temperature exceeding $450^{\circ} \mathrm{C}$.

\section{Process Confinement System}

The Process Confinement System (PCS) provides secondary confinement in the TSF for tritium releases and leaks from process piping and vessels, thus minimizing the potential for a release of tritium to the room. The PCS of the TSF consists of the gloveboxes and secondary confinement of inter-glovebox piping and vessels external to the gloveboxes. A recirculating nitrogen atmosphere acts as a carrier gas to circulate the PCS atmosphere to a metal getter system, where hydrogen isotopes are removed. The removed hydrogen isotopes are stored on metal hydride storage beds, with a 20-mol maximum tritium capacity, of the Tritium Storage System. A recovery system for ${ }^{3} \mathrm{He}$ will be incorporated into the PCS design. Pressure in the PCS is maintained at a nominal 10 torr above ambient pressure in order to minimize the influx of moisture and oxygen into the PCS. The nitrogen atmosphere is continuously monitored for oxygen, and tritium concentrations.

\subsection{Waste Treatment and Disposal}

\subsubsection{Waste Treatment}

Treatment and disposal options for APT wastes are summarized in Table 2. Waste streams in each treatment/disposal category are listed in Appendix F. While compaction only is a viable treatment for low-level waste, all RCRA wastes require some sort of treatment and/or stabilization of the final waste form. Wastes to be either compacted or thermally destroyed consist primarily of job control waste streams. Spent modules will be cut/disassembled to segregate the lead (mixed waste) components from the remainder of the LLRW materials. To meet the RCRA "Debris Rule", the lead sections of the modules will be macro-encapsulated. The possibility of radioactive-contaminated metal recycling should also be investigated by Operations after start-up of the facility, given that SRS is working with commercial vendors to recycle tritiumcontaminated stainless steel from reactor heat exchangers by using it to make waste containers. Additional wastes requiring encapsulation are those containing RCRA-listed heavy metals (e.g., 
batteries and some instrumentation). Because of their small expected total volume, it is recommended to stabilize radioactive-contaminated liquid wastes, such as glovebox bubbler fluids and nonhazardous tritiated oil, in absorbent materials for E-Area Vault disposal. Radioactive process water effluents will be tanked and evaluated for release to the outfall, solidified, or stored for decay.

Table 2. Treatment/Disposal Options for APT Waste Note: Based on Superconducting Option and $\mathrm{He}^{3}$ Target

\begin{tabular}{|c|c|c|c|}
\hline $\begin{array}{c}\text { Treatment/Disposal } \\
\text { Option }\end{array}$ & Waste Type & $\begin{array}{l}\text { Mass } \\
\mathrm{kg} / \mathrm{yr}\end{array}$ & $\begin{array}{c}\text { Volume } \\
\mathrm{m}^{3} / \mathrm{yr}\end{array}$ \\
\hline $\begin{array}{l}\text { Incineration and Stabilization of } \\
\text { Residue }\end{array}$ & $\begin{array}{l}\text { Low-Level } \\
\text { Mixed } \\
\text { Hazardous }\end{array}$ & $\begin{array}{r}68,500 \\
100 \\
390 \\
\end{array}$ & $\begin{array}{r}500.0 \\
0.5 \\
0.4 \\
\end{array}$ \\
\hline $\begin{array}{l}\text { Compaction for LAW Vault } \\
\text { disposal }\end{array}$ & Low-Level & 10,000 & 75.0 \\
\hline Direct LAW Vault Disposal & Low-Level & 493,000 & 758.0 \\
\hline Direct ILTV Bulk Cell Disposal & $\begin{array}{l}\text { Intermediate- } \\
\text { Level }\end{array}$ & 83,000 & 53 \\
\hline $\begin{array}{l}\text { Package for storage and/or off- } \\
\text { site disposal }\end{array}$ & \begin{tabular}{|l} 
LLRW \\
Mixed \\
Hazardous \\
\end{tabular} & $\begin{array}{r}2,400 \\
44,000 \\
1,500 \\
\end{array}$ & $\begin{array}{r}5 \\
13 \\
2.0 \\
\end{array}$ \\
\hline Wastewater Treatment/NPDES & Low-Level & - & 500 \\
\hline Wastewater Treatment/NPDES & $\begin{array}{l}\text { Sanitary/Industria } \\
1\end{array}$ & - & $3,500,000$ \\
\hline
\end{tabular}

PPE job control wastes would be most effectively treated using incineration followed by stabilization of the ash residue. Incineration combined with stabilization would reduce the waste volume by roughly a factor of 10 . If thermal treatment such as incineration is not used for PPE wastes, the majority of APT wastes ( $-95 \%)$ would receive only the most basic treatment (compaction) prior to disposal. This would achieve a volume reduction of 4-6. In addition to providing greater volume reduction, at least one study has shown incineration to be more economical. A recent comparison of waste compaction with off-site treatment and disposal versus on-site incineration conducted by SRS for the Consolidated Incineration Facility concluded that annual operating costs would be $\$ 20.3 \mathrm{M}$ for compaction and $\$ 13.5 \mathrm{M}$ for incineration (Ref. 21). 
This PPDA assumes APT waste streams will be treated and disposed of at SRS. This on site activity will be to the extent that it is technically possible and economically feasible. Existing and planned treatment facilities for SRS are discussed in Appendix C.

\subsubsection{Waste Disposal}

DOE Order 5820.2A requires that all DOE low-level waste (LLW) be disposed of at a DOE disposal facility. APT low-level waste is assumed to be disposed of at SRS in the E-Area Vaults or in a future LLW disposal facility. Other DOE sites capable of receiving APT low-level wastes are the Nevada Test Site (NTS) and Hanford. NTS is a current disposal site for low-level waste (see Section C3.2), but has no treatment capabilities, and none are planned. The Hanford Site is similar to SRS and possesses both treatment and disposal capabilities. A formal application and approval process must be completed before waste can be shipped to either of these two sites. No DOE facility is currently authorized to accept off-site mixed low-level waste (MLLW) for disposal; however, Hanford has accepted some shipments for storage/disposal on a case-by-case basis. Hanford and NTS have RCRA Part B permitted MLLW disposal facilities. The Yucca Mountain Project (YMP) is currently planning to accept spent fuels and vitrified HLW. A new EIS will review the option of disposal of special LLRW streams (i.e. GTCC) that may not meet the Performance Assessments of other available disposal facilities. YMP has no plans to accept mixed wastes. DOE currently allows mixed waste to be shipped to one permitted commercial facility, Envirocare of Utah, Inc., on a case-by-case basis. Other commercial waste disposal facilities capable of receiving and treating low-level and mixed low-level waste are DSSI and SEG in Tennessee. APT hazardous waste, per current SRS practice, could be disposed of at any DOE-approved commercial facility that would accept it.

\subsection{PPDA Critical Assumptions}

The waste streams in this PPDA are estimated based on the following critical assumptions. If these assumptions are changed materially, then the results presented here would need to be updated.

- APT staffing is 650 persons.

- APT operates 24 hours a day, 7 days a week, 365 days a year.

- Waste generation rates are proportional to production activity ( $3 \mathrm{~kg}$ per year).

- Waste minimization initiatives will reduce job control waste for comparable activities by $50 \%$ by the time of APT start-up. 
- Personal protection equipment to be used in the APT will be incinerable. They will need to be manufactured out of non-polyvinyl chloride (PVC) materials. (Current Tritium plastic suits, Tygon tubes and Pylox gloves in use all contain PVC and are therefore not suitable for incineration).

- The administrative control weight limit on a 21 " $\times 21$ " $\times 21$ " cardboard box waste container is 50 lbs.

- For waste forecasting, most tritium processing equipment will be assumed to be constructed of stainless steel.

- Waste Treatment Volume Reduction Factors are assumed as follows:

\begin{tabular}{ll} 
& Volume Reduction Factor \\
\cline { 2 - 2 } Compaction & 4 \\
Supercompaction & 6 \\
Incineration & 40 \\
Stabilization & $1 / 2$ (volume doubles)
\end{tabular}

- Decontamination/cleaning is assumed to occur at the APT, rather than at other potential locations such as the Receiving Basin for Off-site Fuel (RBOF).

- Photographic waste will be minimized by using digital imaging. If conventional silver-based radiographs are taken in radioactive-contaminated environments, they will be decontaminated for disposal as clean waste.

\subsection{Challenging Waste Streams and Waste Management Issues}

The APT will generate several challenging waste streams only partially addressed in this PPDA. Definitive resolution will require collection of additional data, material substitution, or development of new process technologies. These are described below.

\subsubsection{Spent Modules}

\section{Blanket Modules}

The spent blanket modules will be a highly activated lead mixed-waste. The isotopic make-up is based on CINDER 90 computer models and is considered preliminary. Additional modeling will be conducted as will activation tests at LANL. This data will be utilized to provide a more definitive forecast of the waste's decay heat, radiation levels and isotope concentrations. 


\section{Tungsten Targets \& Cavity Windows}

The window and the tungsten targets receive the direct impact of the proton beam and consequently will be highly activated with over 1,000 different isotopes. Because of its high levels of radiation and potentially high concentrations of certain isotopes, detailed evaluation of potential disposal facilities will be required to assure these waste can be made to comply with the Waste Acceptance Criteria without negatively impacting the facility's Performance Assessment. The isotopic make-up is based on CINDER 90 computer models and is considered preliminary. Additional modeling will be conducted as will activation tests at LANL. This data will be utilized to provide a more definitive forecast of the waste's decay heat, radiation levels and isotope concentrations. Additional steel and aluminum components may also require similar evaluation.

\subsubsection{Radioactive Liquid Waste}

A number of liquid streams will be contaminated with radioactivity and cannot be disposed of easily: oil, glovebox bubbler fluid and water. Oil and glovebox bubbler fluid, due to their small anticipated volumes may be disposed as solid waste by stabilizing in an absorbent material and overpacked. This treatment and disposal method will take advantage of institutional control and the tritium decay half-life of 12.3 years, which will reduce tritium by about $99.6 \%$ in 100 years. However, this treatment and disposal method has not been used recently at SRS and an exemption to the EAV WAC may be required. Other strategies for addressing these wastes include reducing the concentration of radioactivity in contaminated cooling water by using oncethrough cooling and in bubbler fluid by more frequent change-out. Operational flexibility in dealing with these waste streams is increased. However, the waste volumes will increase as a trade-off. The blowdown water from the T/B building primary cooling loops will be contaminated and scenarios including discharge to the outfall, stabilization, versus storage for decay must be evaluated based on allowable limits to the NPDES outfall.

\subsubsection{Radionuclide Permeation and Quantification}

It is not possible to determine the radionuclide content in the bulk of a waste component based strictly on detected tritium off-gassing rates. Radioactivity will permeate or diffuse into almost all surfaces that it contacts and will readily exchange with hydrogen-containing materials such as moisture, corrosion oxide products, oils and polymeric materials. The current SRS Tritium Facilities waste characterization plan assigns nominal amounts of tritium to tritium-contaminated piping, flanges, and other miscellaneous standard equipment parts. This includes both analytically determined tritium trapped in corrosion product oxide layers and tritium calculated to permeate into the metal matrix. It is important to use a proper degree of benchmarking for the APT waste. Attaching a "nominal" value to each "type" of waste component, rather than 
analyzing each individually in detail, is cost-effective, but may be non-conservative. This methodology and use of nominal or average values is satisfactory for Curie brokering (tracking and management of radionuclide Curies from waste packages) to meet radionuclide limits and optimize capacity utilization in the E-Area Vaults. From an operational viewpoint, one should be prepared for a radioactivity "puff" release if such waste is compacted, due to the off-gassing of tritium and other nuclides into the waste bag from components containing potentially much higher than "nominal" amounts of tritium/nuclides.

\subsubsection{Waste Classification/Greater-Than-Class C}

There are several waste classification issues. First, the highly radioactive tungsten targets and window waste, which will be remote-handled, is classified as low-level waste under current DOE guidelines. This low-level waste classification or designation (also referred to at SRS as Intermediate Level Waste to distinguish it from contact-handled low-level waste) may be challenged and need to be defended by the DOE.

Secondly, a number of APT waste streams are heavy metals, listed or characteristic mixed waste streams. For example, the blanket modules, containing lead, and the Pd-Ag diffusers containing silver are mixed wastes. However, characteristic wastes may exit RCRA if Toxicity Characteristics Leaching Procedure (TCLP) tests or literature data can show that the hazardous components are not readily leachable. On the other hand, waste streams which include incoloy, zircaloy and stainless steel contain chromium, a RCRA metal. But due to their well-established corrosion resistance, chromium is not considered leachable and these wastes are not considered to be mixed waste in this PPDA.

Lastly, the spent tungsten targets and windows have the potential for exceeding the GreaterThan-Class $\mathrm{C}$ classification for radioactive waste regulated by the Nuclear Regulatory Commission (NRC). Under NRC regulations (10CFR61), greater-than-class $C$ wastes are not considered generally acceptable for near-surface disposal. Limits for greater-than-class $\mathrm{C}$ components such as $\mathrm{C}-14, \mathrm{Ni}-59$, and $\mathrm{Nb}-94$ are listed in Table 4, reproduced from 10CFR61.55 Table 1 and Table 2. If the waste contains more than one of the listed radionuclides, a sum of fractions calculation is required to determine Greater-Than-Class-C classification. The new Radioactive Waste Management Order, 435.1, currently in draft form, does not include the "Special Case" waste classification for LLRW exceeding the GTCC limits. Instead it relies on evaluation of the facility Performance Assessment to identify suitable disposal options. 
Table 3

NRC Greater-Than-Class C

Radionuclide Limits

\begin{tabular}{|l|c|}
\hline \multicolumn{1}{|c|}{ Radionuclide } & Class-C Limit, Ci/m3 \\
\hline \hline C-14 & 8 \\
\hline C-14 in activated metal & 80 \\
\hline Ni-59 in activated metal & 220 \\
\hline Ni-63 & 700 \\
\hline Ni-63 in activated metal & 7,000 \\
\hline Sr-90 & 7,000 \\
\hline Nb-94 in activated metal & 0.2 \\
\hline Tc-99 & 3 \\
\hline I-129 & 0.06 \\
\hline Cs-137 & 4,600 \\
\hline
\end{tabular}

\subsection{Waste Minimization/Pollution Prevention}

\section{Definitions}

As stated in the Waste Minimization/Pollution Prevention Crosscut Plan (U. S. DOE, Office of the Secretary, Washington, D.C., 1994 ), DOE defines Waste Minimization/ Pollution Prevention or WMin/PP as activities involving source reduction and recycling of all wastes and pollutants. It includes practices reducing the use of materials, energy, water, or other resources. It encourages practices that protect natural resources through conservation or more efficient use.

This definition is a consequence of DOE's adoption of the EPA definitions for waste minimization and pollution prevention. EPA defines waste minimization as source reduction and recycling of solid wastes and pollution prevention as the use of materials, processes or practices that reduce or eliminate the creation of pollutants or wastes at the source.

Regulatory Bases 
DOE WMin/PP Activities and Initiatives are directed by the following regulatory guidance:

Executive Order 12856, "Federal Compliance With Right to Know Laws and Pollution Prevention Requirements," August 6,1993, requires development of a pollution prevention strategy and agency development of a $50 \%$ reduction goal in toxic chemicals released by the end of 1999.

Executive Order 12843, "Procurement Requirements and Policies for Ozone-Depleting Substances," April 21,1993, which phases out the manufacturing and use of ozone-depleting substances.

Executive Order 12873, "Federal Acquisition, Recycling and Waste Prevention," October 21,1993 , promotes reductions in waste generation through recycling and use of recycled and energy efficient materials.

DOE Order 5820.2A, "Radioactive Waste Management," requires development of Waste Management Plans including actions to minimize radioactive waste generation.

DOE Order 5400.1, "General Environmental Protection Program," requires development of WMin/PP Plans, annual waste reduction reports, and establishing a pollution prevention awareness program.

DOE Order 5400.3, "Hazardous and Radioactive Mixed Waste Program," requires DOE environmental programs to additionally address RCRA requirements.

\section{WMin/PP Strategy and Opportunities}

An implementation plan for WMin/PP in the DOE Complex was developed in 1994 and documented as the Waste Minimization/Pollution Prevention Crosscut Plan (U. S. DOE, Office of the Secretary, Washington, D.C. ). In 1996 an updated Pollution Prevention Crosscut Plan was formulated documenting DOE goals to reduce hazardous and radioactive waste generation by $50 \%$ by December 31,1999 . Activities identified include objectives for policy direction, infrastructure development and program implementation. An important "Immediate Priority" of the plan applicable to the Accelerator Production of Tritium (APT) Project is the requirement to design WMin/PP into new processes and facilities.

The Pollution Prevention Crosscut Plan identifies a Pollution Prevention Design Assessment as a methodology for implementation. The five steps of the method, to be applied to each design stage, include: 
1. Identify and quantify waste streams anticipated during construction, operation and closure or dismantling of the process or facility. (see App A\&B and CDR)

2. Prioritize streams, set boundaries, and establish goals for the remainder of the design assessment. (see Section 7.0)

3. Identify pollution prevention design opportunities. (see App B)

4. Analyze design alternatives. (see App A\&B)

5. Implement selected pollution prevention design opportunities and document results. (see App B)

\subsection{Overall APT Waste Management and WMin/PP Strategy}

The APT Project's overall waste strategy is to ensure:

1. The APT shall be designed to be capable of pre-treating, treating, accumulating, handling, packaging, certifying, transporting, and minimizing all types of waste generated in the APT in preparation for shipment to a waste treatment, storage or disposal (TSD) facility.

2. The APT will be designed to minimize waste generation through a facility layout minimizing the extent of posted contamination areas.

3. Waste streams are identified and quantities projected based on comparison with existing tritium extraction and loading facilities at SRS, tritium facilities at Los

Alamos

National Laboratory, accelerator facilities at Los Alamos National Laboratory, and other accelerator facilities.

4. TSD facilities or options were identified for all generated waste streams.

5. A Pollution Prevention Design Assessment was conducted and this is the resulting document.

As part of the PPDA, the APT Project evaluated adopting design features such as:

1. A T/B canyon facility

2. Maintenance gloveboxes to minimize job control waste

3. Gloveboxes and room confinement systems to minimize radioactive emissions to the environment 


\section{Vacuum systems to minimize air activation by the beam}

APT operations will reduce waste volumes through compaction and incineration. APT operations will also waste minimize by the recycle and re-use of equipment such as target or module shipping casks. The current APT process alternatives developed by design efforts and brainstorming are documented in this PPDA. APT process alternatives generated in future brainstorming sessions will be evaluated and may result in even less waste generation. Future examples include the use of electrolysis to release elemental tritium from oxides rather than the use of depleted uranium and magnesium beds as in the current SRS extraction technology. Spent uranium and magnesium beds must be replaced periodically and end up as low-level radioactive waste.

\subsection{APT Waste Streams}

APT operations will produce a number of waste streams in gaseous, liquid and solid forms. The gaseous waste will contain radioactive emissions and particulates. Liquid wastes will primarily be non-radioactive process cooling water. Primary cooling loops and other radioactive liquid sources (i.e., Laboratory sinks from Health Protection and Analytical operations, air emission controls) may also discharge radioactive liquid waste. Solid Wastes are expected to make up the bulk of the APT wastes. Solid Waste is expected to include low-level radioactive waste, hazardous waste, low-level mixed waste and sanitary/industrial (landfill) waste. Lowlevel radioactive waste may be further divided into Greater-Than-Class-C, remote-handled, and contact handled.

Decommissioning wastes and strategies for APT are discussed and covered in Appendix H. APT construction wastes are also covered in Appendix $\mathrm{H}$.

\subsection{APT Waste Types}

The APT wastes will be managed for treatment and disposal according to waste type. The APT is expected to generate the following types of Solid Waste: low-level radioactive waste, hazardous waste, mixed waste and sanitary/industrial waste. In addition, tritiumcontaminated aqueous waste with other radionuclides will be generated. These waste types are discussed below. The APT will not produce high-level waste (HLW). It also will not generate transuranic (or TRU) waste.

Low-Level Radioactive Waste

The vast majority of radioactive waste generated by the APT is expected to be low-level radioactive waste (LLRW). APT LLRW is expected to consist of both highly radioactive 
remote-handled waste from the Cavity Vessel and contact handled waste from the majority of the APT radioactive areas. Remote-handled LLRW includes removed modules and certain accelerator components. Some maintenance waste, ion exchange resins, particulate filters, and failed equipment from the $T / B$ facility are also expected to be remote-handled. Contact handled waste will consist mostly of job control waste (shoe covers, plastic sheeting, gloves, plastic suits, etc.) from process operations and analytical waste with trace radionuclide contamination, as well as more highly contaminated and/or activated process equipment waste (piping, valives and fittings, gauges, pumps, metal hydride beds, catalyst beds, zeolite beds, and may include, depending on APT design, spent magnesium and/or depleted uranium beds).

\section{Hazardous Wastes}

Hazardous wastes are wastes containing either listed hazardous components (such as RCRA metals of mercury, lead, etc.) or characteristic hazardous components (reactive, toxic, combustible) above certain threshold compositions. These would be wastes potentially generated in the APT office, change-room, or non-rad process operating areas. Certain batteries, solvents or analytical chemicals may fall into this category. Note: As a pollution prevention measure no hazardous solvents will be used in the APT.

Mixed Low-Level Wastes

A mixed low-level waste or mixed waste is waste both radioactive and hazardous. Mixed wastes will be generated inside contaminated process areas. The majority of this waste category will be generated by the replacement of lead neutron generating modules in the Cavity Vessel. These wastes can be minimized by judicious specification of equipment materials of construction where it is possible.

Sanitary Waste

Sanitary solid waste consists of office-type waste from the APT change rooms, control room, and offices. Sanitary liquid waste is expected to be generated from change rooms and the men's and women's rest rooms.

Radioactive Liquid Waste

Primary cooling loops throughout the APT will generate radioactive liquid waste. Other sources such as laboratory sinks from Health Protection and Analytical operations may discharge radioactive contaminated aqueous waste. 


\subsection{Waste Packaging}

Waste packaging may be divided into remote-handled and contact-handled waste packages. Remote-handled waste is expected to consist of modules, ion exchange resins, particulate filters, and certain failed equipment. Due to its high activity, the modules will probably be disposed of in special waste containers and shipped in a shielded shipping cask. A new target waste container and shipping cask may have to be developed and certified. WAC 3.10 prohibits waste radiating more than $50 \mathrm{R} / \mathrm{hr}$ at $30 \mathrm{~cm}$ from the container. Currently, waste packages exceeding $5 \mathrm{mrem} / \mathrm{hr}$ at $30 \mathrm{~cm}$ are considered non-routine and require advance notification to the EAV operating personnel. There are other waste acceptance criteria such as decay heat release limits and radionuclide concentration limits that must be met.

Contact-handled job control and process equipment LLRW from APT operations, tritium separation, purification, analytical and health protection operations are expected to be packaged in plastic bags and cardboard boxes, per current practice. They are placed in carbon steel B-25 containers. They may be segregated for incineration or compaction. Compacted wastes are disposed of in B-25 containers in the EAV.

\subsection{Conclusions}

The WMin/PP prioritized waste streams for the APT project are hazardous wastes, mixed wastes, and LLRW not meeting current WACs. The boundaries of the WMin/PP effort are all activities associated with constructing, operating, and decommissioning the APT.

The WMin/PP goals of the APT Waste Management Team are:

1. To produce waste capable of treatment/disposal on the SRS (with the notable exception of mixed waste).

2. Also reduce (using this PPDA as the baseline) the total waste produced by another $20 \%$ over the detailed design phase of the APT Project.

3. Refine waste characterization and information to reduce some of the conservatism used in this PPDA.

4. Concentrate on the current APT design and wastes associated with that design. 
Several potential APT hazardous and mixed low-level waste streams have been identified in this PPDA and, except for the lead blanket modules, many may be mitigated or avoided altogether. Appendix B covers in detail the options for mixed/hazardous waste pollution prevention that have been investigated or are possible solutions.

Almost all low-level radioactive waste streams from APT processing operations are expected to meet the current WAC for disposal in the EAV. Reviews of the EAV Performance Assessment determined the spent windows, tungsten targets, and other materials from the cavity vessel cannot meet the SRS WAC as currently written. They do not meet E-Area Vaults Waste Acceptance Criteria with respect to radionuclide distribution, including tritium, and decay heat. A program to include APT radionuclides in the SRS PA revision to be accomplished in FY 98 and to investigate other disposal options has been initiated. Based on these activities a petition for an exemption will be submitted to the Solid Waste Management Division at SRS to initiate a new waste review and potential revision of the EAV WAC 3.10 radionuclide limits. 


\subsection{REFERENCES}

1. Fluor Daniel, "Data Report on Tritium Extraction Facility," Rev. A, August 31, 1994

2. BNL, "Topical Report on Revision-1 of a Pre-Conceptual Design for the SpallationInduced Lithium Conversion (SILC) Target for the Accelerator Production of Tritium (APT)", ATD/APT-xxx (Rev. 0), June 10, 1994.

3. SNL, "Accelerator Production of Tritium Project Process Waste Assessment," SAND942217, UC-721, September 1995.

4. SNL, "Accelerator Production of Tritium Programmatic Environmental Impact Statement Input Submittal," SAND93-2094, November 1, 1993.

5. APT Programmatic Environmental Impact Statement Input Submittal, Rev. 1, May 10 1993.

6. Wilson, Brad, "Tritium Facilities CY95̀ Waste Minimization Plan," NMP-STE-95-0035, April 24, 1995.

7. WSRC, "Defense Program Division Low Level/Mixed Waste Certification Plan," WSRC-IM-95-26, Rev. 1, December 14, 1995.

8. SNL conversation with Luke Bartlein of the TSTA facility, April 26, 1994

9. LANL, "Tritium Systems Test Assembly Final Safety Analysis Report."

10. L. K. Heung et al, "Tritium Confinement in a New Tritium Processing Facility at the Savannah River Site", Fusion Technology, Vol 21, March 1992

11. Theodore Motyka, "The Replacement Tritium Facility", Fusion Technology, Vol 21, March 1992.

12. M. S. Ortman, et al, "Tritium Processing at the Savannah River Site: Present and Future", J. Vac. Sci. Technol., A 8 (3), May/Jun 1990.

13. WSRC, "Savannah River Site Waste Acceptance Criteria Manual,", WSRC IS Manual.

14. H. L. Pope, C. McVay and T. Holm-Hansen, "A 'Fresh Look' at a U. S. Department of Energy Mixed Waste Incinerator," 1994 International Incineration Conference, Houston, TX, May 9-12, 1994 
15. J.L. England, APT Radioactive Wastewater Environmental Impact Statement Outfall Inventory, WSRC-TR-97-0258, Rev 0, 1 August 1997

16. L. Parme, Primary Coolant Activities with excel attachments, email, 8/1/97.

17. J.L. England, Waste Management Plan for the APT, APT-PDO-9710, R0, August 20, 1997.

18. R.H. Hsu, Project S-6091 Commercial Light Water Reactor -Tritium Extraction Facility Process Waste Assessment (U), WSRC-TR-96-0294, Rev 0, October 31, 1996.

19. E. Pitcher, et. al., Cinder 90 Calculations.

20. Facility Design Description (U) for Accelerator Production of Tritium (APT) Plant, GFDD-00004.

21. Final Programmatic Environmental Impact Statement for Tritium Supply and Recycling, DOE/EIS-0161, Office of Reconfiguration, U. S. Department of Energy; 1000 Independence Ave., Washington, DC 20585, Attn: TSR PEIS, October 1995

22. Los Alamos National Laboratory Report, APT Accelerator Topical Report, Rev 1.5, LA-UR-95-1480, March 1995.

23. SRS Environmental Permitting HOW Manual, WSRC-IM-91-69.

24. Resource Conservation and Recovery Act of 1976 (RCRA), Pub. L. 94-580.

25. Comprehensive Environmental Response, Compensation, and Liability Act of 1980 (CERCLA), Pub. L. 96-510.

26. R. Reid, Subject: APT Cooling System Water Use at NTS, ESA-EPE:95-414, August 2, 1995.

27. J.L. England, APT Generation of Long Lived Radionuclides to Include Greater Than Class C Low Level Radioactive Waste Requiring Special Disposal Considerations, WSRC-TR-97-0259, Rev 0, August 20, 1997.

28. 10 CFR 61.55

29. 10, CFR 61.56 
30. DOE Order 5820.2A

31. Nevada Test Site Waste Acceptance Criteria

32. Ades, M.J., Preliminary Disposal Analysis for APT Waste (U), May 19, 1997, SWD-RDE-97-0008.

33. B. Blunt, Radionuclide Releases During Normal Operations for the Target/Blanket Facility, Accelerator Production of Tritium Project, WSRC-TR-97-0243, Rev 1, September 12, 1997.

34. B. Blunt, Radionuclide Releases During Normal Operations for the Tritium Separation Facility, Accelerator Production of Tritium Project, WSRC-TR-97-0241, Rev 1, September 12, 1997.

35. B. Blunt, Radionuclide Releases During Normal Operations for the Accelerator, Accelerator Production of Tritium Project, WSRC-TR-97-0242, Rev 1, September 18, 1997.

36. J.L. England, APT Facility and Infrastructure Decommissioning Waste Estimates, Draft, April 14, 1997.

37. R. Hink, APT Operational Staffing Requirements, Inter Office Memo, February 23, 1996

38. J. Fiorillo, APT-EIS Construction Waste Estimate (U) with excel attachments, email, 7/28/97. 
[This Page Left Intentionally Blank] 


\section{Appendix A \\ APT Processes and Operations}

A simplified description of APT processes and operations is presented in this appendix. In addition, this appendix identifies the solid, liquid and gaseous waste streams generated for each APT system and building. Waste streams identified here are cross referenced to Appendix B of this report, where each waste stream is characterized in detail.

The APT processes and operations described in this appendix are as follows:

\section{A1. Accelerator Systems}

Al.1 Room Temperature Option

A1.2 Inductive-Output Tube Option

A2. Target/Blanket (T/B) Systems

A2.1 Lithium-6 T/B Option

A3. Tritium Separation Facility

A3.1 Lithium-6 T/B Option

A4. Balance of Plant (BOP) Systems

A5. Site and Buildings

\section{Project Design Configuration}

In general, this appendix addresses the proposed design configuration as described in the April 15, 1997 CDR, summarized simply as follows:

\begin{tabular}{|l|l|}
\hline APT Configuration Feature & Proposed Design \\
\hline Target/Blanket (T/B) & Tungsten target and Helium-3 blanket \\
\hline Accelerator Technology & Superconducting (SC) operation \\
\hline Accelerator Power Source (RF Supply) & $\begin{array}{l}\text { Radiofrequency (RF) power tube } \\
\text { (klystron) }\end{array}$ \\
\hline
\end{tabular}

The proposed T/B design is based on a tungsten target and a helium-3 blanket. SC operation of some accelerator components is proposed. And an RF power tube is proposed as the RF supply, or accelerator power source. 
This proposed design is reflected in the following sections of this appendix:

\section{A1. Accelerator Systems}

A2. Target/Blanket (T/B) Systems

A3. Tritium Separation Facility

A4. Balance of Plant (BOP) Systems

A5. Site and Buildings

\section{Alternative Design Configurations}

This appendix also addresses optional, or alternative, design configurations identified in the 1996 APT EIS Notice Of Intent. These options are addressed in the 1997 CDR. Additional 1995 reference documentation for these alternatives consists of two Sandia reports, the PWA and the PEIS Input, and an Extemal Review Committee report.

The alternative design features are summarized simply as follows:

\begin{tabular}{|l|l|}
\hline APT Configuration Feature & Design Alternative \\
\hline Target/Blanket & Lead target and Lithium-6 blanket \\
\hline Accelerator Technology & Room Temperature operation \\
\hline Accelerator Power Source (RF Supply) & Inductive-output tube (IOT) \\
\hline
\end{tabular}

A lead target and lithium- 6 blanket was considered as an alternative to the proposed design. Room temperature operation of all accelerator components was also considered as an alternative. And an IOT was considered as an alternative RF supply, or accelerator power source.

To the extent that they differ from the proposed APT processes and operations, these alternative design configurations are described in the following sections of this appendix:
A1.1 Room Temperature Option
A1.2 Inductive-Output Tube Option
A2.1 Lithium-6 T/B Option (T/B Systems)
A3.1 Lithium-6 T/B Option (TSF) 


\section{A1. Accelerator Systems}

The APT accelerator includes the following subsystems: injector, Low-Energy (LE) linear accelerator (Linac), High-Energy (HE) Linac, high-energy beam transport (HEBT) and expander, cryogenics, radio frequency (RF) power (including klystron systems, klystron power supplies, transmitters, circulators, waveguide, RF transmission, RF windows), and accelerator support systems. In simplified terms, the purpose of these systems is to produce low-energy protons, accelerate the protons in a beam, and deliver the beam to the tritium-production targets. The accelerator tunnel is described and addressed separately below.

The first section of the APT accelerator is the injector system where a continuous stream of protons is generated in an ion source (plasma chamber) and injected at an energy of $75 \mathrm{keV}$ into the LE Linac system.

The second section of the APT accelerator is the LE Linac system, where a radio-frequency quadrupole (RFQ) Linac accelerates the proton beam to $6.7 \mathrm{MeV}$; a Coupled-Cavity Drift-Tube Linac (CCDTL) continues acceleration to $100 \mathrm{MeV}$; and a Couple-Cavity Linac (CCL) further accelerates the beam from $100 \mathrm{MeV}$ to $217 \mathrm{Mev}$, and injects it into the HE Linac system. The RFQ, CCDTL, and CCL are normal-conducting copper structures operating at room temperature maintained by the water cooling and resonance control system.

The HE Linac system is the third section of the APT accelerator, where the beam to is accelerated to its full energy of $1700 \mathrm{MeV}$. The HE Linac consists of a superconducting CCL in two configurations: a three-cavity cryomodule configuration for the medium-beta section, ranging from 217-to-469 MeV; and a four-cavity cryomodule configuration for the high-beta section, ranging from 469-to-1700 MeV. The HE Linac accelerates the beam using superconducting niobium cavities operating at very low temperature $(2 \mathrm{~K})$ maintained by the cryogenic system.

The average current in the Linac systems is $100 \mathrm{~mA}$, and the average beam power is approximately $170 \mathrm{MW}$. Since the beam power and current are large compared with existing linear accelerators, there is a significant potential for damaging energy deposition in accelerating structures and beam transport tunnel if the beam is misdirected or misfocused for short periods of time. There is also a significant potential for activation of accelerating structures and tunnel air if even a small fraction of the beam is lost on a continuous basis.

The HEBT and expander system is the fourth and last section of the APT accelerator. The HEBT/expander directs the beam from the HE Linac to either the tritium-production target or the beamstop. The HEBT/expander consists of bending and focusing magnets and evacuated pipes through which the beam travels, providing the correct expanded beam size and shape at the window module and switches between the target/blanket cavity vessel and the beamstop. 
The RF power system will convert ac power into RF power for establishing the accelerating fields in the LE Linac system and the HE Linac system. The cryogenics system cools the cavities of the HE Linac system to superconducting temperatures.

\section{Accelerator Systems Waste Streams}

Waste streams generated in normal operation of the APT accelerator systems are included in the following waste streams described in Appendix B of this report:

B1. Job Control Waste, including Personal Protection Equipment (such as shoe covers, gloves, plastic sheeting, plastic suits and connecting breathing hoses)

B2. Job Control Waste (Mixed Low-Level Waste)

B3. Nonhazardous Process Equipment (including instrumentation parts, cooling system maintenance material, ion pump materials, Klystron materials, magnets)

B6. Mixed Waste Solvent Rags

B7. Analytical Laboratory/Rad Con Chemicals

B8. Teledyne Oxygen Sensor Micro-Fuel Cells

B11. Radioactive Light Water and Aqueous Solutions

B13. Non-radioactive Process Water

B19. Batteries

\section{B21. APT Radioactive Air Emissions}

Power supplies used for the APT accelerator are heavy-duty industrial units lasting the life of the facility. Most other components of the accelerator are also anticipated to last the life of the facility. Two exceptions are klystrons and ion pumps, requiring periodic replacement and refurbishment. Additional waste streams will result from failed or obsolete monitoring and target beam diagnostic instrumentation, magnets, harps, cooling system maintenance, and personal protection equipment (PPE). 
Because of the potential for system components to be activated or contaminated by activated air or coolant, wastes from the accelerator have the potential to be radioactive. RCRA regulated solvents used in maintenance and items containing heavy metals can introduce hazardous components into the waste streams and generate mixed wastes.

\section{A1.1 Room Temperature Option}

The major differences between room temperature option and superconducting design are the use of niobium cavities for high-energy portion of the linac and the associated cryogenic system in the latter design. In the room temperature design, both LE Linac and HE Linac systems are made up entirely of normal conducting copper accelerating structures that are optimized for accelerating protons in different velocity ranges. These structures are operated at room temperature maintained only by the water cooling and resonance control system. The average current in the Linac systems is $134 \mathrm{~mA}$, and the average beam power is approximately $174 \mathrm{MW}$.

The 134-mA beam current are achieved by funneling at $20 \mathrm{MeV}$ with two low-energy linac sections of 67-mA beams, and adding more RF power stations in the high-energy section of the linac. The combined proton beam is accelerated to $100 \mathrm{MeV}$ in a coupled-cavity drift-tube linac (CCDTL) and then to full energy of $1300-\mathrm{MeV}$ in a series of coupled-cavity linac (CCL) modules powered by $700-\mathrm{MHz}$ RF systems. Radio-frequency (RF) drive is supplied by 1-MW continuous-wave (cw) klystrons, using a redundancy configuration that permits continued operation with failed units.

Waste streams generated in normal operation of the room-temperature design accelerator systems are similar to those generated by the superconducting design systems, except that no cryogenic cooling maintenance material is generated.

\section{A1.2 Inductive-Output Tube Option}

The APT RF Power System presently includes three 1-MW, 350-MHz cw klystrons for the RFQ, and approximately $2701-\mathrm{MW}, 700-\mathrm{MHz} \mathrm{cw}$ klystrons to power the rest of the accelerator. Significant reductions in cost would result from successful development of a new high-efficiency $700-\mathrm{MHz}$ 1-MW cw RF generator using a scheme based on the principles of the inductive output tube (IOT).

The conventional low-technical-risk technology at $700 \mathrm{MHz}$ is the klystron amplifier. Klystron amplifiers provide a saturated efficiency of $65 \%$. However, klystron physics dictate the high efficiency is only realized at the saturated output-power level. At any level below saturation, the efficiency is decreased proportionally to the reduced output power. In accelerator service, the requirement to control the accelerating-cavity-field amplitude and phase forces APT 
to operate $10 \%$ below the saturated output level to allow margin for control. This results in an operational efficiency of $58.5 \%$. This conventional klystron operates at $-95 \mathrm{kV}$ of cathode voltage, requires $4000 \mathrm{~W}$ of magnet power, requires a circulator to protect the klystron from the high reflected power that is often experienced in accelerator applications, and forces the water system to maintain a very tight tolerance on cooling water to preserve efficiency.

Inductive output tubes are routinely used in television broadcast service with power output of $60 \mathrm{~kW}$ cw over the full broadcast band. Two high-power IOT developments have been undertaken: (1) a $425-\mathrm{MHz} 500-\mathrm{kW}$ pulsed IOT, and (2) a $267-\mathrm{MHz} 250-\mathrm{kW}$ cw IOT. The goal is to develop a high-order-mode IOT (HOM-IOT) with an operational efficiency of 0.73 . The HOM-IOT does not requires RF circulator for protection, crowbar, focusing solenoidal magnetic field or focusing power supplies, and could operate at a beam voltage approximately $1 / 3$ of the conventional klystron technology. The design life of the HOM-IOT is in excess of 30,000 hours.

\section{A2. Target/Blanket Systems}

The primary purpose of the target/blanket systems is to produce tritium using proton beam as input. The target/blanket systems comprise a target/blanket assembly and the associated heat removal systems. The supporting heat removal systems safely remove the heat deposited by the proton beam during normal, off-normal and accident conditions. The target/blanket assembly combined with completely separate heat removal systems provide high availability and tritium production assurance.

The target/blanket assembly receives a high-energy proton beam from the accelerator via an entrance window. The proton beam is directed on a heavy water $\left(\mathrm{D}_{2} \mathrm{O}\right)$ cooled tungsten target, which produces neutrons by spallation. Spallation refers to nuclear reactions occurring when high-energy particles (e.g., protons, deuterons, neutrons, pions, and muons) interact with an atomic nucleus (the "target" nucleus).

The high-energy protons interact with the tungsten nucleus to eject neutrons. The target is surrounded adjacently by a decoupler module and followed by several blanket modules containing ${ }^{3} \mathrm{He}$ gas and light water $\left(\mathrm{H}_{2} \mathrm{O}\right)$ moderator. The decoupler module allows high-energy particles to pass through and into the blanket, and to absorb any back-scattered low-energy neutrons in ${ }^{3} \mathrm{He}$ instead of in the tungsten. The lead blanket is to provide neutron multiplication and moderation. A reflector layer containing light water coolant surrounds the blanket modules, and is designed to enhance tritium production efficiency as well as to reduce neutron leakage from the blanket. The neutrons ejected are moderated by $\mathrm{D}_{2} \mathrm{O}, \mathrm{H}_{2} \mathrm{O}$, and lead to an energy low enough to be efficiently absorbed by the tritium-production ${ }^{3} \mathrm{He}$ feedstock. The neutrons are converted to tritium by neutron-proton reactions as illustrated below.

${ }^{3} \mathrm{He}+{ }^{1} \mathrm{n}_{0} \longrightarrow{ }^{3} \mathrm{H}_{1}+{ }^{1} \mathrm{H}_{1}$ 
Almost half of the neutrons are produced in the tungsten neutron source region, and the lead blanket and decoupler modules are responsible for most of the remainder. Tritium diffuses through the static gas to headers connecting ${ }^{3} \mathrm{He}$ gas tubes. A continuous flow of gas through the headers transport the ${ }^{3} \mathrm{He}$ and tritium mixture to a tritium separation facility located in close proximity to the target/blanket assembly.

\section{Target/Blanket Assembly}

The major assembly components that contribute to waste streams for target/blanket operations are the beam entrance window, the tungsten neutron source, the decoupler/blanket modules, and the shield modules. A "modular" arrangement has been adopted to allow for replacement of short-lived components, allow for maintenance and repair, and provide the capability to update or adopt the design for different beam energy or current.

The beam entrance window allows the expanded proton beam to pass through the high-vacuum environment of the HEBT and Expander System. The beam then strikes the tungsten neutron source in the rough-vacuum environment of the target/blanket cavity vessel. The beam entrance window is a double-wall Inconel structure with a gap between the walls for the flow of a low pressure light water. The heat deposit in the window structure is less than $1 \mathrm{MW}$ and is removed by the low-pressure light water coolant.

After passing through the beam entrance window, the proton beam strikes a centrally located assembly of tungsten neutron source cooled with heavy water $\left(\mathrm{D}_{2} \mathrm{O}\right)$ at moderate pressure. The number of neutrons produced per proton by spallation of solid thick tungsten or lead is approximately 31 for a $1 \mathrm{GeV}$ proton beam, and approximately 58 at $1.7 \mathrm{GeV}$. Furthermore, the amount of energy deposited per neutron produced is about a factor of five less than for neutrons produced in a fission reactor.

The neutron source consists of small Inconel-clad tungsten rods contained in horizontal stainless steel tubes. These horizontal tubes are manifolded into larger diameter vertical inlet and outlet pipes that provide a coolant flow of heavy water at moderate pressure. The tubes and manifolds make up a structure called a ladder. The tungsten neutron source consists of 13 such ladders arranged in two modules, one containing six ladders and the other seven.

The tungsten target/lead blanket configuration has been optimized for tritium production by separating the tungsten target region from the lead blanket modules, with a decoupler module. High-energy particles scattered out of the tungsten neutron source easily pass through the decoupler region to enter the blanket modules. The decoupler module consists of several rows of tightly packed aluminum tubes containing ${ }^{3} \mathrm{He}$ with light water coolant flowing outside the tubes, under moderate pressure. The ${ }^{3} \mathrm{He}$ in this region preferentially absorbs the low energy neutrons 
that scatter from the lead blanket, maximizing neutron absorption in ${ }^{3} \mathrm{He}$ and minimizing neutron absorption in tungsten. A major fraction of the total tritium production occurs in the decoupler.

Blanket modules contain lead, ${ }^{3} \mathrm{He}$ gas, aluminum, and light water coolant in various fractions that are tailored to meet thermal hydraulic safety margins while maximizing the tritium production. The lead in the blanket modules provides an additional source of neutrons from additional spallation and $(n, x n)$ reactions. Neutrons are moderated to low energy by collisions in the lead and light water, and are captured in the ${ }^{3} \mathrm{He}$ gas to produce tritium. The blanket lead is cast into cruciform shaped aluminum tubes to form rods. The ${ }^{3} \mathrm{He}$ is contained in blind circular aluminum tubes that are manifolded together at the top and sealed off at the bottom. The rods and tubes are assembled into aluminum housings, which forms the pressure boundary for the light-water coolant. Tritium produced in the ${ }^{3} \mathrm{He}$ diffuses upward to the manifold, where it is removed by a sweep gas flow. The ${ }^{3} \mathrm{He}$ and tritium mixture is continuously transported to a tritium separation facility located in close proximity to the target/blanket stations.

The APT target and blanket components will be exposed to a substantial flux of high-energy protons and other particles. However, each component undergoes a different operating environment with regard to radiation exposure, pressure, temperature, and stress. The structural materials required in the neutron source and beam entrance window are exposed to the expanded $1.7 \mathrm{GeV}, 100 \mathrm{~mA}$ proton beam and a high-energy neutron environment, and are expected to have lifetimes between one and three years. The surrounding decoupler, lead blanket and reflector modules are exposed to scattered high-energy particles and neutrons. Shielding structures and cavity vessel components surrounding the blanket and reflector regions are exposed to mostly low neutron fluxes.

Steel shielding surrounds the blanket modules and decoupler module to minimize activation of the vessel and external structures and to protect workers. In addition, steel shields attached to the top of the target/blanket region facilitate connection and disconnection of coolant and gas lines during module replacement operations. The power density in the first 100 to $200 \mathrm{~cm}$ of shield that surrounds the blanket and reflector is sufficiently high to require some active cooling. The shield modules use light water to remove the decay heat. Outside this region active water cooling is not required due to the low power density.

The cavity vessel is a sealed stainless steel enclosure confining the target/blanket subsystem during operation. The vessel is cylindrical in shape with a removable head structure. With the beam shut down, it can be opened for access to the modules and extraction of internal components during maintenance operations. As a pressure boundary, the vessel provides a 1 torr vacuum atmosphere around the target/blanket for the proton beam to pass through, minimizing air activation. The cavity vessel structure is also a secondary confinement boundary and radionuclide barrier in the event of an internal coolant loss or a ${ }^{3} \mathrm{He}$ gas line leak. In the event of a cavity flood condition, the vessel serves as the pressure boundary for the flood coolant. 


\section{Target/Blanket Waste Streams}

The Target/Blanket Assembly System is expected to generate Low-Level Radioactive Waste, greater-than-Class $C$, and Mixed Low Level Waste. This waste includes the tungsten neutron source, Inconel window modules, and the lead components. Due to radiation damage, the window and tungsten neutron source modules are expected to require replacement every one to three years. The expected life-time of row 2 and 3 blanket modules is three to ten years, and the outer lead blanket and reflector/shield modules should last the plant lifetime of 40 years. Other sources of APT radioactive waste are personal protective equipment (PPE) from routine maintenance and the change-out of T/B assemblies.

The waste target ladder and blanket assemblies are contaminated'with numerous radioactive isotopes including spallation and activation products, and tritiated water vapor. The largest volume and the most significant mixed waste stream will be the RCRA-regulated lead waste. A pool functions as a heat sink and to allow the decay of short-lived, gamma-emitting radionuclides.

Wastes from Target/Blanket Assembly System change-out operations and routine maintenance are included in the following waste streams described in Appendix B:

B1. Job Control Waste

B9. Mixed Waste Lead

B11. Radioactive Light Water and Aqueous Solutions

B12. Radioactive Heavy Water Waste

B15. Tungsten

B16. Window Modules

B17. Steel Shielding

B18. Aluminum

B21. APT Radioactive Air Emissions

\section{T/B Heat Removal Systems}

The primary function of the heat removal systems is to remove heat during full power operation, standby operations, and accident conditions for the Tungsten Neutron Source, the Decoupler Module and the Blanket Modules, the Window Module, and the Shield Modules.

The total beam power entering the window separating the accelerator from the target module is $170 \mathrm{MW}$. Of the $170 \mathrm{MW}$ total, $130 \mathrm{MW}$ is converted to heat which must be carried away. Approximately $38 \mathrm{MW}$ is converted to mass, while the remainder leaks from the system in the form of neutrons. About half of the total power under normal operating conditions is deposited in the tungsten neutron source. The other half is deposited in the regions surrounding the 
tungsten neutron source. When the proton beam is shut down, the power falls very quickly to residue heat levels that are $<1 \%$ of the full-power values.

Tungsten heat removal systems include tungsten heat removal primary system (THRPS), tungsten heat removal secondary system (THRSS), tungsten residual heat removal primary system (TRHRPS), and tungsten residual heat removal secondary system (TRHRSS).

The tungsten heat removal primary system consists of one 100\% capacity heat-transfer loop connected to the inlet and outlet plenums of the tungsten rod bundles. The loop contains three hot leg primary coolant pumps, one heat exchanger, and associated piping. A pressurizer is connected to the tungsten heat removal primary loop to maintain the tungsten target in a flooded condition in the event of an LOCA. The THRPS working fluid is heavy water $\left(\mathrm{D}_{2} \mathrm{O}\right)$.

The tungsten heat removal secondary system consists of one $100 \%$ capacity heat-transfer loop that circulate light water through the primary exchanger and reject the heat to the cooling tower system via the secondary heat exchangers. The loop contains three secondary coolant pumps, a heat exchanger, a surge tank, and associated piping. During a station blackout the rod bundle decay heat may be removed by maintaining primary and secondary natural circulation flows. The secondary loop water is cooled by air-cooled heat exchangers with naturally induced air flow. The THRSS working fluid is light water $\left(\mathrm{H}_{2} \mathrm{O}\right)$.

The tungsten residual heat removal (RHR) systems actively removes decay heat from the target rod bundles and the target heat removal systems when the THRPS and THRSS are unavailable or ineffective for providing heat-removal capability. The tungsten RHR systems consists of two loops, each capable of removing $100 \%$ of the decay heat during normal shutdown mode, operational transients, and DBAs. The tungsten RHR secondary system function is to provide a heat sink to the primary system via an air blast water-to-air heat exchanger. The RHR primary working fluid is heavy water, and light water is used for the RHR secondary.

Blanket heat removal systems includes blanket heat removal primary system (BHRPS), blanket heat removal secondary system (BHRSS), blanket residual heat removal primary system (BRHRPS), and blanket residual heat removal secondary system (BRHRSS). All these systems use light water as working fluid. The blanket heat removal primary and secondary systems are similar in design to the tungsten heat removal systems.

The blanket residual heat removal (RHR) systems actively removes decay heat from the decoupler and blanket modules when the BHRPS and BHRSS is unavailable or ineffective for providing heat-removal capability. The blanket RHR secondary system function is to provide a heat sink to the primary system via an air blast water-to-air heat exchanger.

The window heat removal primary system (WHRPS) function is to remove heat from the window module during operation and shutdown. The function of the window heat removal 
secondary system (WHRSS) is to provide a heat sink to the window heat removal primary system. Both WHRPS and WHRSS use light water as working fluid.

The primary function of the shielding internals is to protect the cavity vessel wall from radiation damage and minimizes its activation. The shield heat removal primary system (SHRPS) function is to remove heat from the shield, lateral blanket rows 4 and 5 , and the reflector modules during operation and shutdown. The function of the shield heat removal secondary system (SHRSS) is to provide a heat sink to the shield heat removal primary system. The working fluid used in shield heat removal systems is light water.

The cavity flood systems serve as the ultimate thermal protection mechanism for the APT target/blanket systems. The cavity flood system rapidly fills the entire target/blanket cavity, immersing all the components and remove the decay heat loads from any target/blanket module. It is expected that the cavity flood system will be used only for low-frequency events, such as an internal-cavity loss of coolant accident (LOCA) or a series of successive failures in the primary or residual heat removal systems. The working fluid used in cavity flood systems is light water.

\section{T/B Heat Removal Waste Streams}

Some waste streams from exposure of the target/blanket to the neutron beam come from the target/blanket heat removal systems. Beam power dissipated in the target and blanket assembly will be removed by the T/B Heat Removal Systems, where spallation and radiolysis products are expected to be produced. Major heat removal system components are expected to last the life of the APT facility. However, routine maintenance of the heat removal primary system will produce wastes including job control wastes, pumps, and the change-out of small equipment parts. Also, leakage in the primary/secondary heat exchangers will result in some radionuclides in the secondary coolant stream.

Wastes from the T/B Heat Removal System are included in the following waste streams described in Appendix B:

B1. Job Control Waste, including Personal Protection Equipment, small equipment parts (such as o-rings, gaskets, pipe fittings, etc.)

B11. Radioactive Light Water and Aqueous Solutions

B12. Radioactive Heavy Water Waste

B21. APT Radioactive Air Emissions

\section{Beamstop Systems}


The beamstop systems include a low energy beam stop, an intermediate energy beamstop, and a high energy beamstop. All are necessary for commissioning and tune-up during operation. . The beamstop systems can also be used to dump the proton beam any time it is necessary to divert it from tritium-production target area without shutting off the accelerator. The high energy beamstop systems is designed for $2 \%$ of normal operating power level of the beam, and can accommodate 3.4 MW for an unlimited time. Any malfunction of the beamstop systems with the potential for reaching excessively high temperatures will lead to a rapid beam shutdown.

The beamstop consists of a graphite plate(s) to intercept and stop the proton beam. The beamstop is designed to passively radiate the deposited power to an actively cooled vessel. Both low and intermediate beamstop vacuum vessels are cooled by water cooling tubes integrated into the outer surface of the vessels. The high energy beamstop uses helium $\left({ }^{4} \mathrm{He}\right)$ as the cooling and inerting medium.

\section{Beamstop Waste Streams}

The major components of the beamstop systems are expected to last the life of the APT facility. However, it has been discussed that window module and graphite modules into which high energy beam is deposited may need change-out after a long period of time within projected lifetime operation. This postulation for beamstop systems needs further verification and evaluation. The components within the beamstop building are "modular" in design, allowing for replacement and maintenance. Routine maintenance will also produce waste, including protective clothing for activities associated with inspection and maintenance activities. In addition, proton beam deposited into graphite plate(s) in beamstops would generate activation products carried by the beamstop cooling media.

Wastes from beamstop operations are included in the following waste streams described in Appendix B:

\section{B1. Job Control Waste}

B11. Radioactive Light Water and Aqueous Solutions

B21. APT Radioactive Air Emissions

\section{A2.1 Lithium-6 T/B Option}

In the Lithium-6 T/B design, the target/blanket systems comprise a target/blanket assembly and the associated heat removal systems. The target/blanket assembly consists of a heavy water $\left(\mathrm{D}_{2} \mathrm{O}\right)$ cooled lead target and $\mathrm{H}_{2} \mathrm{O}$-cooled lithium-aluminum ( $\mathrm{LiAl}$ ) blankets, separated from the 
accelerator by a beam-entrance window (integral to the beam expander duct). The LiAl blankets and the beam expander duct are the tritium-production areas.

High-energy protons will induce spallation in the lead rods, thereby producing neutrons. The Lithium- 6 isotope within the $\mathrm{H}_{2} \mathrm{O}$-cooled lithium-aluminum (LiAl) blankets will capture the thermal neutrons that were moderated by $\mathrm{H}_{2} \mathrm{O}$ and produce tritium by the following equation:

${ }^{6} \mathrm{Li}_{3}+{ }^{1} \mathrm{n}_{0} \longrightarrow{ }^{3} \mathrm{H}_{1}+{ }^{4} \mathrm{He}_{2}$

\section{Lithium-6 Target/Blanket Assembly}

The Lithium-6 target/blanket assembly is installed within the target/blanket cavity. The cavity contains the target and blanket during operation and shutdown cooling prior to removal for tritium extraction and target component refurbishment/disposition. The cavity also contains connections to the target cooling systems, shielding, and structural interfaces to the target components.

The major assembly components that contribute to waste streams for target/blanket operations are the beam entrance window, the lead neutron source, and the tritium production blanket. These elements are configured as inseparable assemblies consisting of individually fabricated components joined to form an integral unit not normally capable of being disassembled for repair. The design approach minimizes material otherwise present in flanges, transfer tubes, etc., and contributes to overall system reliability by reducing seal connections.

The beam entrance window allows the expanded proton beam to pass through the high-vacuum environment of the expander duct and enters the lead neutron source in a vacuum environment of the target/blanket cavity. A significant fraction of tritium production in the Lithium-6 T/B takes place in the expander duct LiAl plates. Both the beam entrance window/expander duct and the source blanket are constructed of aluminum clad $\mathrm{LiAl}$ alloy plates.

The neutron source target (or also called source array) consists of aluminum-clad lead rods with integrally extruded helical ribs to maintain uniform rod spacing when the rods are grouped into bundles. Each rod is retained at the inlet end of pressure tube by swaging of the inlet and fitting to a perforated capture plate. The other end of the rod is unrestained, which allows the rods to expand freely in operation. These bundles are housed in aluminum pressure tubes of varying sizes that maintain the rod bundle arrangement and serve as a pressure boundary for the flow of the $\mathrm{D}_{2} \mathrm{O}$ coolant. The pressure tubes containing the rod bundles are arranged vertically in rows and joined top and bottom by coolant cross headers. The cross headers are in turn connected to two inlets and two outlet pipes. These pipes connect to the two loops of cooling systems. 
The LiAl blanket consists of two subassemblies, the U-Blanket, which covers the bottom and sides of the neutron source array, and the L-Blanket, which covers the top and back. The LiAl blanket surrounds the neutron source array, and captures nearly all neutron generated in the source. As beam exposure progresses, the tritium inventory builds up in the LiAl blanket. Tritium is extracted in a batch process after the beam expander and source blanket assemblies are removed. Blanket modules can be removed from the target/blanket chamber without removing the neutron source array.

\section{Lithium-6 Target/Blanket Waste Streams}

The Lithium-6 Target/Blanket Assembly System is expected to generate Low-Level wastes of mainly spent components and personal protective equipment (PPE) from routine maintenance. Due to radiation damage, the beam expander duct/window and blanket assemblies will be changed out at the end of each annual production cycle. The neutron source array will be used for two cycles prior to changeout.

Wastes from Lithium-6 Target/Blanket Assembly System change-out operations and routine maintenance are included in the following waste streams described in Appendix B:

B9. Mixed Waste Lead

B21. APT Radioactive Air Emissions

B22. Job Control Waste

B23. Spent LiAl Extraction

\section{Lithium-6 T/B Heat Removal Systems}

The primary function of the heat removal systems for the Lithium-6 T/B option is to remove heat during full power operation, standby operations, and accident conditions for the Lead Neutron Source Array, the LiAl Blankets, the Window/Expansion Duct, and the Target Cavity Flood.

The total beam power entering the window separating the accelerator from the target module is $170 \mathrm{MW}$. Of the $170 \mathrm{MW}$ total, $130 \mathrm{MW}$ is converted to heat which must be carried away. Approximately $38 \mathrm{MW}$ is converted to mass, while the remainder leaks from the system in the form of neutrons. About half of the total power under normal operating conditions is deposited in the neutron source. The other half is deposited in the regions surrounding the neutron source. When the proton beam is shut down, the power falls very quickly to residue heat levels that are $<1 \%$ of the full-power values.

The Lead Neutron Source Array heat removal systems include source primary cooling system (SPCS), source secondary cooling system (SSCS), source residual primary cooling system 
(SRPCS), and source residual secondary cooling system (SRSCS). All of the systems contain two loops. The main cooling systems contain two 50\% loops for normal operation where both trains are required to function. The loss of any one loop during the normal operation will trip the accelerator. All of the residual heat cooling systems use two $100 \%$ loops, including the passive cooling capability included in the SPCS and the SSCS through a natural draft water-to-air exchanger, thus each of the residual heat cooling trains is redundant.

The primary function of the SRPCS is to remove decay heat from the lead source assemblies when the beam is shut down and to cool down the source for replacement when SPCS is not available for cooling by either normal operation or natural circulation. The SRPCS consists of two loops, each capable of removing $100 \%$ of the decay heat of about $1 \mathrm{MW}$ for the lead source following an accident. The SRSCS function is to provide a heat sink to the primary system via a natural draft water-to-air heat exchanger. The SRPCS primary working fluid is heavy water, and light water is for the SRSCS.

Blanket cooling systems includes blanket primary cooling system (BPCS), blanket secondary cooling system (BSCS), blanket circulating water system (BCWS), blanket residual primary cooling system (BRPCS), and blanket residual secondary cooling system (BRSCS). All of the systems contain two loops. The main cooling systems contain two $50 \%$ loops for normal operation where both trains are required to function. The loss of any one loop in the BPCS, $\mathrm{BSCS}$, or BCWS during the normal operation will trip the accelerator. All of the residual heat cooling systems use two $100 \%$ loops, including the passive cooling capability included in the BPCS and the BSCS through a natural draft water-to-air exchanger, thus each of the residual heat cooling trains is redundant. The BPCS provides forced circulation of the blanket coolant, $\mathrm{H} 2 \mathrm{O}$, to remove energy generated within the blanket assemblies. This energy is transferred to BSCS under all conditions when AC power is available, except when the system is depressurized. When the system is depressurized, the beam must be shut down and cooling transferred to either the passive system or the BRPCS.

The window and expander cooling system (WECS) function is to remove heat deposited in the window during operation and shutdown. It is composed of the window primary cooling system (WPCS), the window secondary cooling system (WSCS), and the window circulating cooling system (WCWS). All of the systems contain two loops. Each loop provides $50 \%$ of the window cooling and one of the loops provides additional cooling for the expander duct assembly. Both systems are required to function (i.e., the loss of either loop in the cooling trains will result in an accelerator trip). Since the residual decay heat is very low, the passive cooling capability provided by the WPCS and the WSCS to their surroundings was considered to be adequate for residual decay heat cooling.

The target cavity flood systems serve as the ultimate thermal protection mechanism for the APT target/blanket systems in the event of a LOCA (loss of coolant accident) in the SPCS or BPCS. The cavity flood system rapidly (in about 90 seconds following a signal for a LOCA) fills the 
entire target/blanket cavity, immersing all the components and remove the decay heat loads from any target/blanket components. The working fluid used in cavity flood systems is light water. To accommodate cleanup of the cavity, a drain pump is provided that can return the water to the storage tank. In conjunction with this forced return a heat exchanger has been included with the capability to remove about $1 \mathrm{MW}$ of energy. The use of this pump and heat exchanger could serve as a backup for all of the decay heat removal systems.

\section{Lithium-6 T/B Heat Removal Waste Streams}

Some waste streams from exposure of the target/blanket to the neutron beam come from the target/blanket heat removal systems. Beam power dissipated in the target and blanket assembly will be removed by the T/B Heat Removal Systems, in which spallation and radiolysis products are expected to be produced. Cooling system components are expected to last the life of the APT facility. However, routine maintenance in heat removal primary system will produce wastes including job control wastes and change-out of small equipment parts. Also, leakage in the primary/secondary heat exchangers will result in tritium in the secondary coolant stream.

Wastes from the Lithium-6 T/B Heat Removal System are included in the following waste streams described in Appendix B:
B1. Job Control Waste, including Personal Protection Equipment, small equipment parts (such as o-rings, gaskets, pipe fittings, etc.)
B 11. Radioactive Light Water and Aqueous Solutions
B12. Radioactive Heavy Water Waste
B21. APT Radioactive Air Emissions 


\section{A3. Tritium Separation Facility}

Waste streams from tritium separation processing include all wastes produced during tritium extraction, hydrogen isotope separation, tritium enrichment, and storage for shipment. The ${ }^{3} \mathrm{He}$ gas stream containing low levels of hydrogen isotopes from the target/blanket assembly is sent to the tritium separation facility (TSF) to separate the hydrogen isotopes and clean the gas of impurities before it is returned to the target/blanket assembly. The TSF chemically and isotopically purifies the tritium to $99.5 \%$. The TSF comprises seven subsystems: tritium extraction system (TES), isotope separation system (ISS), waste gas tritium clean-up system (WGTCS), tritium storage system (TSS), process confinement System (PCS), ${ }^{3} \mathrm{He}$ supply system (HSS), and analytical laboratory system (ACS).

\section{Tritium Extraction System}

The tritium extraction system (TES) separates hydrogen isotopes and removes non-hydrogen isotope impurities from the ${ }^{3} \mathrm{He}$ stream of the Target/Blanket Gas Transport Subsystem (T/BGTS). A total of five tritium extraction systems will be contained within the TSF. These extraction systems interface with two TES network manifolds located within the T/B building, one manifold dedicated to each T/B. The manifolds are used for directing the GTS inventory from the T/B modules to the TES and returning the cleaned ${ }^{3} \mathrm{He}$ from the TES to the T/B modules.

Before the ${ }^{3} \mathrm{He}$ stream reaches TES, heated metal getter beds and high-efficiency metal filters in series are used to remove impurities and spallation products. In addition, a series of molecular sieve beds (MSB) (zeolite beds) will be used to remove water from GTS in the event of a leak into the system.

The ${ }^{3} \mathrm{He}$ stream is directed through a series of two palladium-silver membrane permeators nominally heated to $425^{\circ} \mathrm{C}$. The palladium-silver membranes are operated at a pressure of $9 \mathrm{x}$ $10^{5} \mathrm{~Pa}(130 \mathrm{psia})$ on the GTS side of the permeator and a ultra-high vacuum $\left(<10^{-5}\right.$ torr) on the shell side of the membrane. Hydrogen isotopes permeating to the shell side of the permeators are pumped to metal hydride storage beds of the TSS. The ${ }^{3} \mathrm{He}$ stream exiting from the permeators is recirculated back to the appropriate T/B modules.

\section{TES Waste Streams}

The Tritium Extraction System is continuously operated since tritium is removed and processed as it is generated. The TES permeators will recover a minimum of $90 \%$ of the hydrogen isotopes 
in a single pass. During normal operations, no significant waste streams would be generated from the TES with ${ }^{3} \mathrm{He}$ target design. However, routine maintenance will produce the following waste streams described in Appendix B:

B1. Job Control Waste, including Personal Protection Equipment, small equipment parts (such as o-rings, gaskets, pipe fittings, etc.)

B3a. Uranium/Magnesium Beds

B3b. Zeolite Beds

B4. Palladium-Silver Permeator Waste Process Equipment

B4a. Silver Plated Waste Fittings

B10a. Glovebox Bubbler Fluid

\section{Isotope Separation System}

The primary function of the Isotope Separation System (ISS) is to concentrate a high-purity tritium stream by separating the mixture of tritium and protium with a small amount of deuterium (D) including $T_{2}, D_{2}, H_{2}, D T, H T, H D$ from the stream. A secondary function is to reduce the residual tritium concentration in the mixture waste stream under normal operation conditions to a level allowing it to be sent to the facility stack without further processing. These functions are accomplished using a cryogenic distillation system, consisting of two sequential columns in combination with four isotope catalytic equilibrators. Two identical distillation systems, connected in parallel and each is capable of individually satisfying the performance criteria, will be installed.

The isotope equilibrator is a room-temperature reactor, packed with a $\mathrm{Pd} / \mathrm{Al}$ catalyst that serves to partially convert the mixed isotopes $\mathrm{HD}, \mathrm{HT}$, and $\mathrm{DT}$ to $\mathrm{T}_{2}, \mathrm{D}_{2}$, and $\mathrm{H}_{2}$. Distillation columns provides the principal tritium separation function for the ISS, producing a tritium product stream exceeding 99.5 molar\% tritium from Column 1. Under normal conditions, the distillate stream exiting from Column 2 is directly vented to the stack. Under the off-normal conditions when the $\mathrm{T}$ concentration exceeds $10 \mathrm{ppm}$, the stream is automatically diverted to the Waste Gas Tritium Clean-Up System.

Cryogenic distillation utilizes the liquid-gas equilibrium in the temperature range of liquid hydrogen $\left(20\right.$ to $\left.30^{\circ} \mathrm{K}\right)$. A refrigeration system with helium circulation is used for safety. Distillation columns are 15-20 feet tall. The columns have a small diameter and require considerable insulation. They should last indefinitely and require minimal maintenance. The wastes generated from cryogenic distillation are mainly failed valves and instrumentation (i.e., temperature and pressure gauges). 


\section{ISS Waste Streams}

During normal operations, no significant waste streams would be generated from the Isotope Separation System with ${ }^{3} \mathrm{He}$ target design. Routine maintenance may require change-out of some parts or equipment and thus produce wastes. In addition, the low level protium and deuterium gas streams containing tritium at less than $10 \mathrm{ppm}$ is sent to the TSF HVAC exhaust system and stack. Wastes from ISS operations are included in the following waste streams described in Appendix B:
B1. Job Control Waste
B3. Nonhazardous Process Equipment
B3b. Palladium-Aluminum Catalyst
B4a. Silver Plated Waste Fittings
B8. Teledyne Oxygen Sensor Micro-Fuel Cells
B21. APT Radioactive Air Emissions

\section{Waste Gas Tritium Clean-Up System}

The Waste Gas Tritium Clean-Up System (WGTCS) is to remove tritium and hydrogen isotopes from tritium-contaminated nitrogen streams during APT operations before discharging them to the environment. Tritium contaminated nitrogen streams are generated from the nitrogen flushes of process equipment, airlocks and transfer containers, and spent target modules from the T/B Gas Handling system, from the BOP Waste Gas system and the Tritium Recovery system. Tritium-contaminated gas streams are stored in two 2500 -liter storage tanks. One storage tank is designated the high tritium concentration receiver and accepts contaminated gas streams from the evacuation of nitrogen flushes of process equipment and from the T/B Gas Handling system. The second storage tank is designated the low tritium concentration receiver and accepts contaminated gas from nitrogen flushes of airlocks and transfer containers.

Tritium-contaminated nitrogen is pumped from the receiver through a preheater and metal getter beds to remove the low levels of oxygen, moisture, ammonia, and methane that may be present in the gas stream. The hydrogen isotopes are removed from the gas stream using a series of metal hydride storage beds operated nominally at $250^{\circ} \mathrm{C}$. The nitrogen stream at the outlet of the storage beds is sent to the TSF HVAC exhaust system if the residual T concentration is below the acceptable limit of $10 \mathrm{ppm}$. If the $\mathrm{T}$ level is above this limit, the nitrogen stream is recirculated through the WGTCS until the level is reduced below the limit before the nitrogen stream is sent to the stack.

\section{WGTCS Waste Streams}


During normal operations, no significant waste streams would be generated from the Waste Gas Tritium Clean-Up System. Routine maintenance may require change-out of some parts or equipment and produce wastes. In addition, the nitrogen gas streams containing tritium of less than $10 \mathrm{ppm}$ is sent to the TSF HVAC exhaust system and stack. Wastes from WGTCS operations are included in the following waste streams described in Appendix B:
B1. Job Control Waste
B3. Nonhazardous Process Equipment
B3a. Uranium/Magnesium Beds
B3b. Hydride Beds
B4a. Silver Plated Waste Fittings
B21. APT Radioactive Air Emissions

\section{Process Confinement System}

The Process Confinement System (PCS) provides secondary confinement in the TSF for tritium and ${ }^{3} \mathrm{He}$ releases and leaks from process piping and vessels, thus minimizing the potential for a release of tritium and ${ }^{3} \mathrm{He}$ to operating areas. $\mathrm{A}^{3} \mathrm{He}$ recovery system is incorporated into the PCS design. Pressure in the PCS is maintained at an ambient pressure \pm 10 torr in order to minimize the influx of moisture and oxygen into the PCS. The nitrogen atmosphere is continuously monitored for oxygen and tritium concentrations.

The PCS of the TSF consists of the gloveboxes and secondary confinement of inter-glovebox piping, and double-walled vessels external to the gloveboxes. A recirculating nitrogen atmosphere acts as a carrier gas to circulate the PCS atmosphere to the metal getter beds system, where gaseous impurities and hydrogen isotopes are removed. Hydrogen isotopes are removed and stored on metal hydride storage beds, 20-mol capacity of the TSS. The PCS will contain a process to remove ${ }^{3} \mathrm{He}$ from the nitrogen atmosphere using either diffusion or membrane technology. The ${ }^{3} \mathrm{He}$ recovered will be transferred to the Helium Supply system.

Each PCS glovebox has an airlock, for the routine movement of material into and out of the PCS, and a transfer container, for the movement of larger components, such as pumps. The airlocks and transfer containers interface with the low-pressure nitrogen system to provide flush gas, and the purge WGTCS for evacuation of the flush gas.

\section{PCS Waste Streams}

During normal operations, no significant waste streams would be generated from Process Confinement System. Routine maintenance may require change-out of some parts or equipment 
and produce job control wastes. Wastes from PCS operations are included in the following waste streams described in Appendix B:
B1. Job Control Waste
B3. Nonhazardous Process Equipment
B4a. Silver Plated Waste Fittings
B8. Teledyne Oxygen Sensor Micro-Fuel Cells
B10a. Glovebox Bubbler Fluid

\section{Analytical Laboratory System}

The Analytical Laboratory System (ALS) is to perform qualitative and quantitative chemical and radiochemical analysis of the TSF and T/B Gas handling system gas streams; and perform tritium analysis of water samples from the T/B Heat removal system and storage pool..

Process piping and volumes in the ALS that contain quantities of tritium above a limit to be determined by a hazard analysis will be located within a glovebox. Process piping and volumes of the ALS with lower quantities at risk will not be located in a glovebox.

The analytical equipment of the ALS includes gas-transfer and sample preparation systems, two mass spectrometers, two laser Raman spectrometers, two liquid scintillation counters, a gas chromatography with mass spectrometer detector, three calorimeters, two Low-Level multichannel gamma-ray analysis systems, a tritium ion-chamber calibration system, a gas-flow meter calibration system, a pressure and vacuum transducer calibration system, a solid waste tritium analysis system, a gas blending system to prepare standard gas mixtures, and a gas proportional tritium counting system.

\section{ALS Waste Streams}

The Analytical Laboratory System is expected to generate Low-Level, hazardous, or mixed LowLevel solid \& liquid waste. For example, compressed gas cylinders are subject to surface contamination with tritium or activation products present in the APT systems. Compressed gases are RCRA hazardous waste code D001. Wastes from ALS operations are included in the following waste streams described in Appendix B:

B1. Job Control Waste

B3. Nonhazardous Process Equipment

B4a. Silver Plated Waste Fittings

B7 Analytical Laboratory/Rad Con Chemicals

B8. Teledyne Oxygen Sensor Micro-Fuel Cells

B11. Radioactive Light Water and Aqueous Solutions 


\section{Helium-3 Supply System}

The Helium-3 Supply System (HSS) provides a continuous supply of ${ }^{3} \mathrm{He}$ to the Target/Blanket Gas Transport Subsystem (T/B-GTS) at a constant pressure of $9 \times 10^{5} \mathrm{~Pa}(130$ psia) to operate the T/B. The ${ }^{3} \mathrm{He}$ for the T/B-GTS is supplied by gas cylinders within the TSF and from ${ }^{3} \mathrm{He}$ recovered from other TSF systems.

The ${ }^{3} \mathrm{He}$ cylinders will be stored and attached to the HSS manifold in accordance with OSHA guidelines. A pressure regulator will be installed to maintain pressure in the T/B-GTS. Check valves will be installed to prevent backflow from the T/B-GTS circulation loop to the HSS. A low-pressure pump train will be employed to recover gas from the TSS to the HSS charging tank.

During operation, gas cylinders provide the initial fill and make-up ${ }^{3} \mathrm{He}$ and hydrogen to T/BGTS. The cylinders attach to a gas manifold that allows the installation and removal of cylinders without impacting T/B-GTS operation. T/B-GTS pressure is maintained by a pressure regulator, and make-up is provided from the ${ }^{3} \mathrm{He}$ gas cylinders.

Following a scheduled or unscheduled shutdown of a T/B-GTS circulation loop, the ${ }^{3} \mathrm{He}$ is diverted to large, evacuated TSS storage tanks located in the T/B Building. The ${ }^{3} \mathrm{He}$ passes through a series of molecular sieve beds, metal getter beds, and filters to remove potential moisture, spallation, or activation products prior to storage in the tanks. Recovery of the gas requires pumping the gas with a scroll pump and metal bellows pump combination from the storage tank to a charging tank located within the TSF. A dedicated compressor is used to pressurize the circulation loop to $9 \times 10^{5} \mathrm{~Pa}(130 \mathrm{psia})$ from the charging tank.

\section{HSS Waste Streams}

No radioactive waste from the ${ }^{3} \mathrm{He}$ Supply System is expected. However, pressure regulators, valves, fittings and tubing may need to be changed out as sanitary waste during operations. Wastes from the HSS are included in the following waste streams described in Appendix B.

\section{B14. Sanitary and Industrial Waste}

\section{Tritium Storage System (TSS)}

The Tritium Storage System (TSS) interfaces with the TSF systems by providing metal hydride beds for storage of hydrogen isotopes, in-process storage tanks for storage of hydrogen isotopes 
and ${ }^{3} \mathrm{He}$ mixtures. In addition, the TSS provides for loading high-purity tritium into approved containers for shipment to the Tritium Facilities at SRS.

Storage tanks located external to the PCS gloveboxes will be double-walled vessels. Storage tanks inside the PCS can be single-walled vessels. The metal hydride beds internal or external to the PCS will be double-walled vessels. All storage tanks and beds will be constructed of an austenitic stainless steel. The size of the storage tanks will vary, depending on their service function. The storage capacity requirement for the double-walled storage tanks within the TSF is $160 \mathrm{~m}^{3}$. The metal hydride beds will be designed for a maximum of 20 -mol tritium storage capacity. The tritium stored on the metal hydride storage beds can be recovered as a gas by heating the beds to a temperature exceeding $500^{\circ} \mathrm{C}$.

In order to provide for the sampling of tank contents for analysis, storage tanks interface with ALS mass spectrometers via capillaries. Metal hydride storage beds utilize an in-situ method of accountability to determine the quantity of tritium contained on each bed. In addition, the TSS employs a manifold to transfer high-purity tritium from metal hydride storage beds to a storage container for shipment to the SRS Tritium Facilities. The gas is transferred to a standard volume for analysis prior to loading into the storage container for shipment. A precision pressure gauge is used to monitor the loading process.

\section{TSS Waste Streams}

During normal operations, no significant waste streams would be generated from Tritium Storage System. However, routine maintenance may need change-out of some parts or equipment and thus produce wastes. Wastes from TSS operations are included in the following waste streams described in Appendix B:
B1. Job Control Waste
B3. Nonhazardous Process Equipment
B3b. Hydride Beds
B4a. Silver Plated Waste Fittings
B8. Teledyne Oxygen Sensor Micro-Fuel Cells

\section{A3.1 Lithium-6 T/B Option}

The APT tritium processing facilities for the Lithium-6 T/B option will be similar to the TSF for the He-3 target design except the Tritium Extraction System (TES) and Helium-3 Supply System. The Lithium-6 T/B option does not need Helium-3 supply system. The Tritium Extraction System for the Lithium-6 T/B option will be performed at on-site facility similar to the current tritium extraction facilities at SRS, and will extract $99.9 \%$ of the tritium from melted 
LiAl target material. The APT tritium processing facility will make use of the latest technology to enhance operational safety, ensure material safeguards and security, and avoid tritium losses to the environment. Waste streams from tritium separation processing for the Lithium-6 T/B option will be mainly the wastes produced by Tritium Extraction System plus waste streams from other subsystems similar to the He-3 target design.

\section{Tritium Extraction System}

Blanket and beam expander assemblies will be separated into stacks of LiAl plates for tritium extraction in an on-site facility that uses an updated version of technology that has been in use at SRS for almost 40 years. The plates are sealed in stainless steel crucibles and melted in a vacuum furnace to release tritium, helium, and impurities such as protium, deuterium, water and methane. Heating is controlled to keep the pressure of the gases escaping the heated targets low to minimize the tritium being absorbed by the furnace walls. The furnace and associated process equipment are installed in glove boxes filled with nitrogen to contain any tritium that may leak out during insertion and removal of the crucibles. The furnace and accompanying lead shielding should last for the life of the facility. After the extraction, the crucible containing the spent melt is packaged for disposal as low-level solid waste. A stripper system removes tritium from the recirculating glove box atmosphere.

At SRS the hydrogen isotopes released in a target extraction furnace are separated from helium and impurity gases by permeation of the hydrogen isotopes through palladium-silver alloy diffusers. A similar process will be used for the LiAl target process for APT. Impurities such as ammonia and methane may contain tritium and cannot be released without treatment. Oxygen is added to the impurity stream and the ammonia, methane, and other hydrocarbons are oxidized in a catalytic reactor. Tritium in the impurity stream is oxidized to water, which is removed in a cold trap and sent to electrolysis cells where the oxygen is separated from the hydrogen isotopes. The hydrogen isotopes is then sent to the isotope separation system (ISS).

\section{TES Waste Streams - Lithium-6 T/B Option}

Both the melt and crucibles are contaminated with tritium and activation products, and will be disposed as a single unit. In addition, the TES will generate wastes streams of discarded process equipment or parts and failed furnace components (such as cover, heaters and gaskets).

Equipment may include vessels, tanks, pressure gauges, valves and fittings as well as pneumatic cutters, video cameras, cranes and confinement box parts.

B3d. Palladium/Electrolysis Membrane

B22. Job Control Waste

B23. Spent LiAl Extraction 
B24. Nonhazardous Process Equipment

B24a. Failed Furnace Component 


\section{A4. Balance of Plant (BOP) Systems}

\section{Power Supply System (PSS)}

The APT facility receives $450 \mathrm{MW}$ electric power from a South Carolina Electric and Gas (SCE\&G) supply grid, convert it to the required voltages functions, and distribute it to two major sections: the section of the low-energy end of the accelerator and miscellaneous BOP loads, and the other section of the high-energy end of the accelerator, T/B building, TSF, and miscellaneous BOP loads. The electrical power system provides normal power to the APT loads at the following plant nominal system voltages: $4160 \mathrm{Vac}, 480 \mathrm{Y} / 277 \mathrm{Vac}, 208 \mathrm{Y} / 120 \mathrm{Vac}$, and $125 \mathrm{Vac}$.

A standby electric power supply will be needed to provide short-term backup power to support safety-related system loads in the event of a temporary failure of the electric power supply. Standby power will be provided at the $480 \mathrm{Vac}$ and $120 \mathrm{Vac}$ utilization level by diesel generators or uninterruptible power supplies (UPS). In addition, station batteries are used to provide dc power to substation control and protective equipment. The station batteries also provide power to the uninterruptible power supplies.

\section{PSS Waste Streams}

Burning diesel during testing or emergency operation will generate a waste gas stream containing carbon monoxide, carbon dioxide and flue of incomplete combustion. Servicing of the diesel generator and UPS will also generate waste from replacement of non-recyclable equipment parts such as switches and power distribution, etc. Wastes from PSS operations are included in the following waste streams described in Appendix B:

B14. Sanitary and Industrial Waste

B20. APT Non-Radioactive Air Emissions

\section{Heat Removal Systems}

The balance of plant (BOP) heat removal system is divided into six major subsystems:

- Accelerator secondary (including cryogenics cooling). The accelerator secondary heat removal subsystem provides cooling water to the RF components of the accelerator, including the RFQ, CCDTLs, and CCLs, as well as the magnets, RF circulator, RF switch, RF splitters, low-energy beamstop, klystron cooling networks, and cryogenics facilities. In addition to removing waste heat from the primary heat removal heat exchanger, this subsystem also 
provides a means of cooling the process chillers, pump bearings and seals, compressors, and various other cooling loads located in or near the Accelerator Tunnel and Klystron Gallery.

- T/B secondary (only RHR, window, and cavity flood) and tertiary. The T/B tertiary heat removal subsystem provides cooling water to the secondary heat exchanger supplying the tungsten ladder and blanket cooling loops. Tertiary cooling is also provided to one of the secondary heat exchanger supplying the window, de-coupler, reflector, and shielding cooling loops. The tertiary heat removal system also provides cooling to pump bearings and seals, compressors, and various other cooling loads located in or near the T/B Building.

The T/B secondary subsystem provides the secondary and final cooling loops for the target and blanket RHR cooling loops; one of the window, de-coupler, reflector, and shielding cooling loop; and cavity flood cooling loop. This subsystem consists of pumps, liquid-air and liquid-liquid heat exchangers, cooling towers, storage tanks, surge tanks, distribution piping, and field instrumentation and controls required by the cooling loops.

- Klystron remanufacturing facility primary and secondary. This subsystem provides cooling water to the klystron test stands, pump bearings and seals, compressors, and various other cooling loads located in or near the klystron remanufacturing facility.

- Target storage pool primary. This subsystem provides a cooling loop to remove decay heat from the target/blanket assemblies and wastes stored in the storage pool.

- Beamstop secondary (only RHR and Cask cooling) and Tertiary. This subsystem provides the tertiary cooling loop to the beamstop system. The secondary and final cooling loop is also provided by this subsystem for the beamstop RHR primary cooling loop and beamstop module storage casks primary cooling loop.

- Tritium Separation Facility (TSF) secondary. This subsystem provides secondary open cooling loop to the Tritium Separation Systems. This subsystem consists of pumps, chillers, cooling towers, mixing valves, and associated distribution piping.

The BOP heat removal system covers all cooling loops transferring waste heat directly to the ultimate heat sink. This includes all open cooling tower circulation loops (tertiary and some secondary) and secondary liquid to air heat exchangers.

\section{Heat Removal Waste Streams}

The Heat Removal Systems are expected to generate low level liquid waste and routine maintenance wastes. Wastes from the Heat Removal System are included in the following waste streams described in Appendix B: 


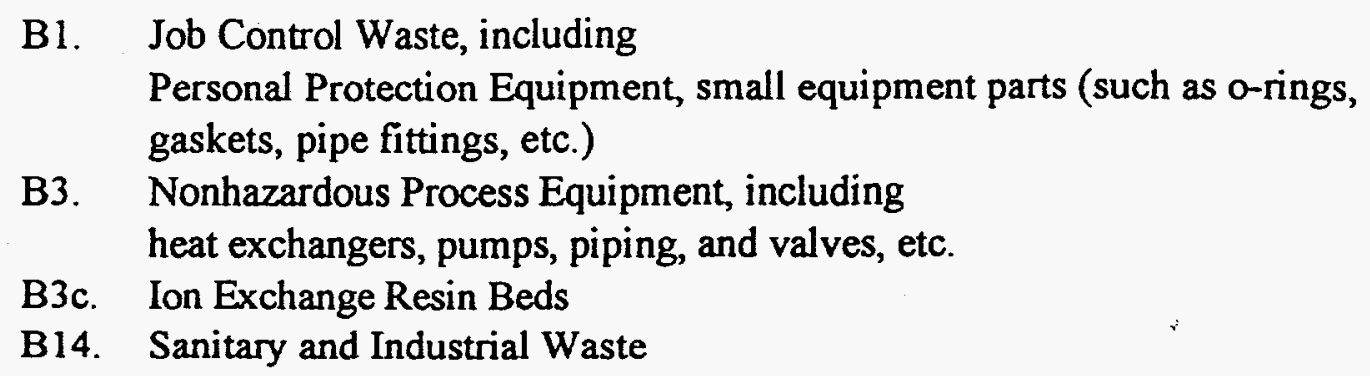

\section{HVAC Systems}

HVAC system will provide all APT facilities sufficient ventilation for human occupancy, and maintain required temperature and relative humidity conditions for human comfort and equipment. In addition, the HVAC system will maintain most process-related areas under slight positive pressure relative to the atmosphere, and provide flow control and confinement of airborne radionuclides. The HVAC system for both process facilities and BOP facilities will consist of chillers, air-handling units including heating and cooling coils, dampers, HEPA filters, fans, systems, and instrumentation and controls.

The HVAC system includes the following subsystems to support various APT process facilities:

- Accelerator Tunnel HVAC system. This subsystem will include recirculation system to provide cooling for space temperature and humidity control during the accelerator operation. This subsystem also provides general supply air system to provide cooling/heating and ventilation in the tunnel for maintenance personnel during the shutdown mode. The exhaust air will be HEPA-filtered before release to the environment through the HVAC stack.

- Target/blanket ventilation system. This subsystem is once-through type to eliminate the potential for recycling tritium in the event of release. Cooling in this area will also be provided by chilled water cooling coils provided in the supply air-handling unit. Chilled water will be provided by the central chilled water plant.

All the equipment cubicles will be adequately ventilated to remove airborne radionuclides and to offset heat gain from equipment. Supply and exhaust air will be proportionally controlled to ensure that negative pressure is maintained in the building. This subsystem will be designed to assure the direction of the air flow is maintained from the regions of low radionuclide contamination to regions of higher contamination. The exhaust air will be HEPA-filtered before release to the environment through the HVAC stack. 
- Tritium separation facility (TSF) HVAC system. This subsystem will consist of two independent systems, one for the tritium production area (radiological controlled area) and another for offices and control room (nonradiological) areas.

- Offices and the control room HVAC system. This subsystem will be designed to operate at a constant volume with a minimum amount of return air exhausted.

- Klystron Gallery HVAC system. This subsystem will provide required cooling, heating and ventilation for the working personnel in or near the Klystron Gallery area. Supply air will be exhausted through building louvers. Chilled water for cooling will be provided by the central chilled water system.

- $\mathrm{RF}$ wave guides ventilation system. This ventilation subsystem is provided to maintain the enclosure temperature at or below $120^{\circ} \mathrm{F}$.

\section{HVAC Waste Streams}

The level and inventory of radioactive material within HVAC will be very small during normal or off-normal operations. This is because the majority of the radioactivity generated in the APT will be gases, which pass through the HVAC system. However, release of radioactive particulates such as tungsten oxide from a remote-handling accident or vessel leakage will be collected by the HVAC HEPAs. Any contaminated HEPAs will be replaced and the accessible sections of the HVAC system will be decontaminated prior to proceeding with operations. As the result, the HVAC is expected to generate duct work, gaskets and other maintenance parts, gauges, sensors, and HEPA filters. Wastes from the HVAC System are included in the following waste streams described in Appendix B:

\section{B1. Job Control Waste \\ B3. Nonhazardous Process Equipment \\ B3e. HEPA Filters}

\section{Radioactive Waste Treatment System (RWTS)}

The radioactive waste treatment system (RWTS) will accomplish all required handling, preparation, treatment, packaging and storage of APT-generated Low-Level radioactive waste (LLRW) and mixed wastes before ultimate disposal. No high-level or transuranic wastes will be generated by the APT processes. The APT radioactive waste systems interface with and utilize compatible waste facilities at SRS. The APT RWTS will include systems to process and handle solid, liquid, and gaseous radioactive waste streams. 
The major sources of APT radioactive waste (radwaste) are spent resin from water treatment ion exchange, personal protective equipment (PPE), job control material from routine operation and maintenance activities, and the change-out of tungsten neutron source/decoupler modules, blanket modules, reflector modules, shield modules and window modules. Waste streams from these activities account for roughly three-fourths of all radioactive waste streams generated by the APT. The primary treatment for PPE and job control wastes will be incineration in the SRS Consolidated Incineration Facility (CIF).

The solid radioactive waste treatment system will receive and treat solid radioactive wastes generated in APT operation and maintenance activities, and will package wastes to be transported from the APT facility to meet the waste acceptance criteria (WAC) of the receiving facility for treatment, storage, or disposal. All waste destined for off-site disposal must be packaged according to DOT regulations for transport of hazardous and/or radioactive materials.

The tungsten neutron source/decoupler modules and blanket modules contain significant amount of lead (Resource Conservation and Recovery Act [RCRA] regulated material) and are contaminated with numerous radioactive isotopes. These $\mathrm{T} / \mathrm{B}$ wastes will be initially placed into the target pools for cooling and subsequent tritium recovery. After tritium recovery is complete, they will be treated and packaged to meet applicable RCRA requirements and WAC prior to disposal.

The gaseous radwaste treatment system will receive and process waste gases from the T/B heat removal systems, the cavity vessel and atmosphere system, gas-transport system, and vented gases from various other BOP systems. These waste gases will be processed through a oncethrough pre-HEPA filter, a caustic scrubber, a dryer, and a HEPA filter, and are then transported to decay holding tanks before exhausting to the BOP HVAC stack. Water removed from the moisture separators and wastewater from the gas scrubber is discharged to the liquid radwaste treatment system.

The liquid radwaste treatment system will accept and treat heavy water, light water, process water liquid wastes with low total dissolved solids, and high dissolved solids to remove radioactive contaminants. The liquid radwaste system consists of a heavy-water radwaste system, a light-water radwaste system, and a process-water radwaste system. The heavy-and light-water radwaste systems include a resin-drying system including dewatering within a High Integrity Container (HIC), a liquid retention system, and a reverse-osmosis system. The process-water radwaste system includes accelerator tunnel waste collection systems, target/blanket building waste collection systems, oil separation systems, and reverse-osmosis systems. The microfilter backwash and reverse osmosis rejectate will be transferred to an evaporator. Gases and vapor vented from the holding tanks, backwash tank, concentrate tank, condensate tank, oil tank, and evaporator are routed to the gaseous radwaste treatment system. 
Nitrogen gas is supplied to the gas space of the tanks to prevent air leaks into the tank. The nitrogen is used as inerting gas to reduce flammability resulting from the accumulation of hydrogen gas.

\section{RWTS Waste Streams}

The radioactive waste treatment system is expected to generate evaporator discharge, spent resin, failed filters and membranes, and job control wastes from routine maintenance and spill cleanup activities. Spent resin from liquid radwaste system is another major source of APT radioactive wastes in addition to personal protective equipment (PPE), job control wastes from routine maintenance, and the change-out of $\mathrm{T} / \mathrm{B}$ assemblies. The contaminated ion-exchange resin will be dewatered and sealed in the HICs to less than $1 \%$ of the resin volume in residual water prior to shipment to final disposition. The evaporator discharge will also be characterized and stored for ultimate disposal as a solid waste. Wastes from the RWTS are included in the following waste streams described in Appendix B:
B1. Job Control Waste
B2. Job Control Waste (Mixed Low Level Waste)
B3. Nonhazardous Process Equipment
B3c. Ion Exchange Resin Beds
B3e. HEPA Filters

\section{Remote-Handling System (RHS)}

The remote-handling system (RHS) provides equipment to perform operations when any mechanical assistance is required due to the object's weight or size or where ALARA considerations restrict contact maintenance. The primary purpose of these systems is to provide maintenance, inspection, and remote handling functions required for the unique equipment of the APT facilities: Accelerator Facility, Target/Blanket Facility, Tritium Separation Facility, and High-Energy Beamstop Facility. Standard industrial maintenance and material-handing equipment, such as that for BOP functions, is not included in the scope of this system.

In the Accelerator Facility, material-handling systems (cranes, hoists, transport carts, etc.) are provided for components in the Accelerator Tunnel and Klystron Gallery, including beam tube components, vacuum system components, RF system components, electromagnet system components, beam-diagnostic sensors, and klystrons. In the accelerator tunnel, remote handling equipment is also provided to allow maintenance and inspection where ALARA considerations may restrict contact maintenance. 
In the Target/Blanket Facility and the High-Energy Beamstop Facility, material-handling systems (cranes, hoists, transport carts, etc.) are provided for components including target vessel confinement lid and remote handling equipment is provided for replacing the spent tungsten target modules, spent lead and steel modules, and beam tube exit windows, and for replacing the High-Energy Beamstop and associated window. Remote handling systems are also provided for the segregation of mixed waste and to prepare and package waste for transport.

In the Tritium Separation Facility (TSF), material-handling equipment is provided to support production of oversize/heavy equipment into, and removal of contaminated oversized/heavy equipment from, the various gloveboxes or confinement boxes without breaching confinement integrity or introducing air into the confinement box. Material handling is also provided for movement of heavy objects within the gloveboxes.

\section{RHS Waste Streams}

The remote handling system is expected to generate wastes from change-out of remote-handling and material handling equipment that have failed from normal wear and tear or the associated parts that are structurally weakened. The metal have just surface contamination, may have tritium diffused into the metal, or may have been activated. Wastes from the RHS are included in the following waste streams described in Appendix B:
B1. Job Control Waste
B2. Job Control Waste (Mixed Low Level Waste)
B3. Nonhazardous Process Equipment

\section{Water Treatment System (WTS)}

The Water Treatment System (WTS) consists of closed-loop chemical treatment and polishing subsystems, open-loop evaporative cooling tower treatment subsystems, process water subsystem, and make-up deionized water subsystem. In addition, this system supplies treated water of the required quality for the various plant cooling systems: deionized water for the magnets in the accelerator systems and Klystron maintenance plant, and closed-loop primary heat removal systems; polished water is returned to its respective closed-loop cooling system; process filtered water for the closed-loop secondary heat removal systems and make-up deionized water system; and process filtered water for domestic use.

The closed-loop chemical treatment systems and open-loop evaporative cooling tower water treatment systems require chemical addition to minimize corrosion and scaling deposit on heat exchanger surfaces and other equipment, and control biological growth. The closed-loop water polishing systems include the tungsten target, window, blanket, shield, target storage pool, and 
beamstop polishing secondary heat removal (HR) systems. Each closed-loop water polishing system consists of prefilters, pumps, mixed-bed ion exchangers, and afterfilters with valves, piping, and control instrumentation. The process water system consists of one water storage tank, feed pumps, and prefilters with valves, piping, and control instrumentation.

The make-up deionized water system is a complete deionized water system, including its auxiliaries. Major components of this system consists of feed pumps, cation exchangers, degasifier, anion exchangers, mixed-bed ion exchangers, afterfilters, and storage tanks. The auxiliaries include a waste treatment system, chemical unloading stations, chemical storage tanks, and the deionized water distribution system. Resin regeneration of the ion exchangers is automatically controlled and performed by chemical addition, backwashing, and rising operations.

\section{WTS Waste Streams}

Major components of open-loop cooling water tower treatment systems, closed-loop polishing and chemical treatment system, process water system, and demineralized make-up water system are expected to last the life of the APT facility. However, routine maintenance will produce wastes. Pumps generally have a life expectancy of ten years. Both open-loop and closed-loop cooling systems will require routine maintenance to provide effective cooling, and thus will generate used chemical containers, solvent rags, and failed parts in the associated water treatment systems. The evaporation of open-loop cooling tower water will result in the buildup of minerals in the remaining water. Therefore, a blowdown stream must be removed and make-up water added to maintain the mineral concentration at acceptable levels. Cooling tower media will become clogged with mineral deposits and will be replaced every year or two.

Ion exchange resin beds of the closed-loop polishing systems will also need change-outs every few years due to aging or fouling problems. All filters in the closed-loop polishing systems are backwashable. Both the spent resin and the backwash slurry are routed to the dewatering highintegrity container (HIC) for further processing by the radioactive waste treatment system. The demineralized make-up water system will generate wastewater from backwash of ion exchangers. This backwash wastewater is routed to a backwash collection tank for neutralization, and then is pumped to a filter press for dewatering. The return water is piped to the process water storage tank. Solid waste from the filter press is loaded into drums for offsite disposal.

Wastes from open-loop cooling water tower treatment systems, closed-loop chemical system, process water system, and demineralized make-up water system are included in the following waste streams described in Appendix B:

B13. Non-Radioactive Process Water

B14. Sanitary and Industrial Waste 
Wastes from closed-loop polishing systems are included in the following waste streams described in Appendix B:
B1. Job Control Waste
B3. Nonhazardous Process Equipment
B3c. Ion Exchange Resin Beds
B11. Radioactive Light Water and Aqueous Solutions
B12. Radioactive Heavy Water Waste

\section{Integrated Control System (ICS)}

Operation of the APT facility, including the accelerator, T/B, TSF and BOP, is accomplished from a centralized location, the main control room (MCR). APT plant process systems, security systems, and other systems providing facility-wide coverage, or local critical coverage, are integrated into the overall operation of MCR and connected to the integrated control system (ICS) network.

The ICS provides global function to integrate and control APT systems, include operator interface, data acquisition, alarm management, data archiving and retrieval, modeling and simulation (accelerator only), timing function (accelerator only), data distribution, self-checks and diagnostics, save and restore capability, automatic sequencing, closed-loop control and system tuning, mode control, and equipment protection.

The ICS also provide system-specific monitoring and control functions. These could be used during system checkout, startup, operation, shutdown, maintenance and other modes consistent with approved facility operating procedures.

\section{ICS Waste Streams}

No radioactive wastes from ICS are expected. However, equipment may need to be changed out as sanitary waste during operations. Wastes from ICS are included in the following waste streams described in Appendix B.

\section{B14. Sanitary and Industrial Waste}

\section{Radiation Monitoring and Protection System}


The radiation monitoring and protection system (RMPS) is designed to protect the public and plant personnel from radiological hazards during all modes of operation. RMPS accomplishes this task by shutting down the accelerator beam, initiating cavity flood, providing monitoring and controls to maintain the APT in a safe shut-down conditions, and by providing SSCs and administrative controls to prevent inadvertent access to hazardous beam induced radiation areas by plant personnel.

The RMPS is divided into two major systems. The Target/Blanket Beamtrip System (TBBS) provides the safety class function of ensuring radiological protection for the public and SRS personnel. The Radiation Exposure Protection System (REPS) provides for the safety significant protection of the facility personnel from hazardous beam induced radiation levels.

\section{RMPS Waste Streams}

Waste streams from radiation monitoring and protection system will primarily result from failed or obsolete monitoring instrumentation. Wastes from the RMTS are included in the following waste streams described in Appendix B.
B1. Job Control Waste
B3. Nonhazardous Process Equipment
B7. Analytical Laboratory/Rad Con Chemicals
B8. Teledyne Oxygen Sensor Microfuel Cells

\section{Air System}

The air systems include the breathing air system, instrument air system, and service air system, which perform general service functions. Compressed instrument air is needed to operate instruments, solenoid valves and other controllers. Breathing air is provided to air-respiratory equipment, and the service air is supplied for general utility use, such as maintenance air cleaning, pneumatic air tools, and air-testing services.

\section{Air System Waste Streams}

No radioactive wastes from air systems are expected. However, pressure regulators, valves, fittings and tubing may need to be changed out as sanitary waste during operations. Wastes from air systems are included in the following waste streams described in Appendix B.

B14. Sanitary and Industrial Waste 


\section{Inert Gas System (IGS)}

The Inert Gas System will provide low-pressure nitrogen gas (LPN) and high-pressure nitrogen gas (HPN) to the vapor spaces of the T/B primary coolant accumulators and pressurizers, accelerator primary coolant surge tanks, liquid waste hold tanks, reverse osmosis hold tanks, demineralizer water storage tanks, and cryogenic plant. The nitrogen supply system consists of two packaged double-walled liquid-nitrogen storage tanks with vaporizers, control valves, pressure-relief valves, and control instrumentation.

\section{IGS Waste Streams}

No radioactive waste from the IGS is expected. However, pressure regulators, valves, fittings and tubing may need to be changed out as sanitary waste during operations. Wastes from the IGS are included in the following waste streams described in Appendix B.

\section{B14. Sanitary and Industrial Waste}

\section{Domestic Water System (DWS)}

Domestic water will be used for all plumbing fixtures, hose bibs, water heaters, make-up water (including fire protection storage tank make-up water), emergency eye-wash stations, safety showers, and similar usage. Domestic water will be supplied from the SRS water distribution system, distributed to APT facilities by a separate service line. Domestic water supply may also be used as a source of the process water for the laboratories, neutralization, scrubbers, and boilers/chillers make-up. Hot water will be provided for plumbing fixtures in toilet rooms, janitor closets, equipment rooms, break rooms, and other locations.

\section{DWS Waste Streams}

No radioactive waste from the Domestic Water System is expected. Sanitary liquid waste will be generated. In addition, pressure regulators, valves, fittings and tubing will be changed out during operations. Wastes from the DWS are included in the following waste streams described in Appendix B.

B14. Sanitary and Industrial Waste

Fire Protection System (FPS) 
The fire protection system is comprised of the fire detection and alarm systems and fire suppression systems, and will include active and passive components. The fire protection system include water supply subsystem, exterior water distribution subsystem, interior water distribution subsystems, automatic suppression subsystems, manual standpipe and hose subsystems, fire detection systems, and fire alarm subsystems.

\section{FPS Waste Streams}

The fire protection system is expected to generate non-radioactive and low-level radioactive liquid waste. Inadvertent discharge of fire protection water or planned discharge during testing is collected in process sewer system and sent to the Liquid Radwaste System or process wastewater plant for further processing. Wastes from the FPS are included in the following waste streams described in Appendix B.

\section{B11. Radioactive Light Water and Aqueous Solutions}

B13. Non-Radioactive Wastewater

\section{Sanitary Sewer System (SSS)}

Areas with no, or very low potential for, radioactive contamination will be connected via the sanitary sewer system to the SRS sanitary sewer system. The sanitary sewer will be connected to all plumbing fixtures in rest rooms, janitor closets, break room, and other applicable locations within these areas. The sanitary sewer system will be provided with a sump pump to lift sanitary sewer flow from the basement floor drains to the site sanitary sewer system.

\section{SSS Waste Streams}

No radioactive waste from the sanitary sewer system is expected. However, piping, valves, fittings may need to be changed out as sanitary waste during operations. Wastes from the SSS are included in the following waste streams described in Appendix B.

\section{B14. Sanitary and Industrial Waste}

\section{Process Sewer System (PSS)}

The Process Sewer System consists primarily of floor drains in facilities where the potential for radiological contamination exists. These structures include, but not limited to, the Accelerator Tunnel, T/B facility, Radwaste Facilities, and the Tritium Separation Facility (TSF). 
Sources such as the floor drains, janitors sinks, and system letdown connections are routed to a facility collection tank for holdup and monitoring. These tanks are discharged to the Liquid Radwaste System for further processing. The system effluent is gravity-drained to the collection tank wherever possible.

The process sewer holding tanks are designed to accept Low-Level, high-solids liquid waste and are therefore equipped with agitators to prevent the accumulation of settlement. They are continuously vented to the gaseous radwaste system.

\section{PSS Waste Streams}

Liquid and gaseous radioactive wastes are expected to be generated. Liquid radioactive wastes from the PSS are included in the following waste streams described in Appendix B.

B11. Radioactive Light Water and Aqueous Solutions

B21. APT Radioactive Air Emissions

\section{Non-Radioactive Waste Treatment System}

The nonradioactive waste treatment system (Nonrad WTS)will also provide any required storage, treatment, and packaging capabilities prior to shipment for treatment and disposal of all APTgenerated nonradioactive wastes (except domestic wastewater which will be transmitted directly from the APT sewer system to the SRS sanitary sewer system). In addition to any other nonradioactive liquid waste, the non-radioactive waste treatment system will handle domestic, industrial, and hazardous solid wastes. Finally, the nonradioactive waste treatment system will track waste generation and interface with existing and planned SRS waste facilities and programs.

\section{Nonrad WTS Waste Streams}

No radioactive waste from non-radioactive waste treatment system is expected. However, some sanitary wastes from plant personnel will be generated during operations. Wastes from nonradioactive waste treatment system are included in the following waste streams described in Appendix B.

B 14. Sanitary and Industrial Waste

\section{Safeguards and Security System}


The APT facility will be protected as a property protection area (PPA) per DOE M 5632.1C as a minimum. Certain facilities within PPA will require additional protection measures prescribed for an Exclusive Area (EA). The APT facilities will be protected by a number of safeguards and security protective measures. Successful entry to the facility may require passing through an explosive detection system, a metal detection system, a badging system, and guard stations.

The APT will be incorporated into the SRS Site Safeguards and Security Plan as required by DOE 470.1, "Safety and Security Programs". In addition, protection afforded special nuclear material will be graded according to nuclear material safeguards category as defined in DOE 5633.3B, Control and Accountability of Nuclear Material.

\section{Safeguards and Security Waste Streams}

No waste from the safeguards and security system is expected.

\section{Health Protection and Environmental Monitoring System (HP\&EMS)}

The health protection and effluent monitoring system (HP\&EMS) covers radiation protection design (including radiation shielding and personnel breathing air system), radiation monitoring equipment to protect facility personnel, and monitoring equipment to detect airborne and aqueous effluent releases. HP\&EMS does not include the process radiation monitors.

\section{HP\&EMS Waste Streams}

Waste streams from health protection and environmental monitoring system will primarily result from failed or obsolete monitoring instrumentation. Wastes from HP\&EMS are included in the following waste streams described in Appendix B.

\section{B3. Nonhazardous Process Equipment}

\section{Plant Communications System}

The communication system supports internal (within the APT plant) and external communications designed to provide convenient and effective operational communications between various plant buildings and plant location, and between the APT and SRS general site. The internal plant communications equipment consists of a public address subsystem and soundpowered telephone subsystem. 


\section{Plant Communications Waste Streams}

No waste from the plant communications system is expected.

\section{Logistics Support System}

The APT logistics support system (LSS) will order, receive, and store bulk containers of hydrogen and other fuels and gases needed for APT operation as well as office and maintenance supplies (consumable) needed by the APT facility.

\section{Logistics Support Waste Streams}

No radioactive waste from logistics support system is expected. However, some sanitary and industrial wastes such as failed container or gas cylinder may be generated during operations. Wastes from LSS are included in the following waste streams described in Appendix B.

B14. Sanitary and Industrial Waste 


\section{A5. Site and Buildings}

\section{Accelerator Tunnel}

The accelerator is housed in a rectangular-shaped, reinforced-concrete structure that is buried under 12 to $15 \mathrm{~m}$ (39 to $49 \mathrm{ft}$ ) of earth. The overall length is about $1,120 \mathrm{~m}(3674 \mathrm{ft})$. The tunnel is sealed during operation. During shutdown conditions, the air in the tunnel is exhausted to the atmosphere through a delay line and a stack. Air in the accelerator tunnel is activated by radiation from beam loss along the accelerating structure and beam path. The tunnel air is isolated from the environment during the beam exposure operations and for an appropriate isolation period after shutdown. Since the dominant activated air products are short-lived radionuclides (decay very rapidly with half lives of seconds to hours)., an isolation period of one hour will reduce the amount of radioactivity by a factor of ten.

The composition of the radioactivity of the air released from the accelerator tunnel is shown below:

\begin{tabular}{ll} 
Isotope & Activity Distribution (\%) \\
\cline { 2 - 2 } C-10 & \\
C-11 & 0.8 \\
N-13 & 48.4 \\
N-16 & 18.6 \\
O-14 & 0.2 \\
O-15 & 1.1 \\
Ar-41 & 24.8 \\
& 6.1
\end{tabular}

The amount of radioactivity released from the accelerator due to air leakage from the tunnel during normal beam operations and due to air exhaust from the tunnel following shutdown for maintenance was estimated based on experience at LAMPF. Conservative analyses of the release to the environment due to air leakage from the tunnel during the normal beam operations yield a release of $87 \mathrm{Ci}$ per year at the surface. Similar conservative analyses for the release of activated air to the environment following beam shutdown for maintenance result in a release of $83 \mathrm{Ci}$ per year.

\section{Klystron Gallery}

The Klystron Gallery extends the length of the injector and main acceleration tunnel sections. It is located adjacent to the tunnel berm. The gallery houses the klystrons and associated support components that produce the radio-frequency (RF) waves that power the accelerator. The gallery includes the control panels, crowbar, high-voltage oil tank, and SCR (silicon-controlled 
rectifier) controller. The gallery accommodates all the controls, cabling, and access required to operate and maintain the systems. The Klystron Gallery is divided into 10 zones by means of fire walls. A 5-ton bridge crane is located in each zone to facilitate servicing of the klystrons and associated equipment. Personnel access from the Klystron Gallery to the Accelerator Tunnel is provided by means of elevators leading to the Accelerator ramps.

\section{T/B Building (\& Beamstop Building)}

This building houses the T/B assembly and its associated equipment for the collection of tritium. The primary function of the Target/Blanket Systems is to generate tritium and deliver it to the Tritium Separation Facility. The T/B Building is a reinforced-concrete structure with three floors below grade and one-above grade. The above-grade floor is referred to as the operating deck and is covered with a structural-steel roof. The structure below the operating deck contains the T/B assembly, cooling water systems, water treatment system, safety-related instrumentation and batteries, and target storage pool.

The retargeting bay is a concrete structure located above the center portion of the operating deck, which provides shielding and crane support for the retargeting operations. To either side of the retargeting bay are steel-frame structures with siding that provide an environmental enclosure for the balance of the operating deck. The operating deck and associated cranes will accommodate laydown for retargeting activities. An interim storage area is designed for cooling and radiation shielding for spent target/blanket heat-generating assemblies removed from the target cavity.

The radioactive waste areas in the T/B Building contain the systems that accept, store, sample, monitor, and process liquid radioactive waste produced by APT before discharge to National Pollution Discharge Elimination System (NPDES) and South Carolina Department of Health and Environmental Control (SCDHEC) permitted outfalls or other disposal. The area provides holdup storage of heavy and light water using high-intensity containers within leak detection pits. Risk of leaks to the environment will be reduced by minimizing line lengths, double-walled piping, and confinement leak detection. The area will accommodate all necessary shielding, breathing air supply, and decontamination capabilities to comply with ALARA, as well as necessary containment, laydown, and access space required to operate and maintain the facility.

The Beamstop Building houses the beamstop and its associated equipment. The building consist of two parts. The first part houses the beam expansion, the beamstop, and associated shielding. It is a reinforced-concrete structure that extends from a top of basement elevation of $-63 \mathrm{ft}$ to a top of shield slab elevation of $+11 \mathrm{ft}$. The second part of the building is a three-level reinforcedconcrete structure that houses the beamstop primary and RHR heat removal systems. The part of the building has a basement at elevation of $-35 \mathrm{ft}$, an intermediate floor at elevation $-12 \mathrm{ft}$, and a shield slab at elevation $+21 \mathrm{ft}$. A structural-steel frame building sits atop the shield slabs and provides weather protection for the access plugs in the shield slab. 


\section{TSF Building}

The TSF Building provides an environmental enclosure for the tritium separation process. It is located adjacent to the T/B Building to minimize the length of piping runs. The primary function of the Tritium Separation Facility (TSF) is to extract and purify the tritium gas contained in the

${ }^{3} \mathrm{He}$ gas stream that circulates through the Target/Blanket Systems. During the normal course of operation of the APT facility, a mixture of tritium and protium, along with a small amount of deuterium, is produced in the T/B System and extracted from ${ }^{3} \mathrm{He}$ stream in the TES. The purified tritium product is stored by the TSF and loaded into shipping containers for transportation to Tritium Facilities at SRS. The TSF is capable of extracting and purifying up to $4.2 \mathrm{~kg}$ of tritium per year.

In addition to the process areas for the separation of helium and tritium, the TSF Building includes a physics laboratory, shipping area, maintenance rooms, control room, support center, and administrative and management functional areas. The TSF is a reinforced-concrete roof, wall, and mat structure in the process area and a steel-frame structure with metal siding on reinforcedconcrete footings for the support area and access bay. The floors of the facility process area and access bay are slabs on grade.

\section{Radioactive Waste Building}

The Radioactive Waste Building houses the radioactive Solid Radioactive Waste Treatment System, and provides storage for packaged radioactive waste prior to shipment for final disposition. The building is structural steel with metal siding on a reinforced-concrete foundation. Facilities are provided for monitoring exterior radiation levels and contamination.

The radioactive wastes generated by the APT facility will be classified as low level and mixed waste. There will be no high-level or transuranic wastes generated by APT. DOE Order 5820.2A requires all DOE Low-Level wastes be disposed in a DOE disposal facility, of which SRS is one. The Solid Radioactive Waste Treatment System will receive and treat solid radioactive and mixed wastes generated in APT operation and maintenance activities, and ensure that all packaged wastes transported from the APT facility will meet the waste acceptance criteria (WAC) of the receiving facility for treatment, storage, or disposal. All low level and mixed wastes must be characterized to determine the physical and chemical characteristics and radionuclide contents for segregation of various waste streams before packaging. This data will be recorded for use during all stages of the waste management process.

\section{Support Facilities}


The APT Support Facilities support and integrate accelerator, T/B, and TSF operations, providing the balance of plant (BOP) mission. The broad array of support elements include:

- Administration Building - The Administration Building is a reinforced-masonry or -concrete structure. This building provides offices, a document control area, conference rooms, lunchrooms and medical facilities for APT management and staff.

- Access Control Building - This building provides facilities for controlling access to the TSF Building and the Blanket/Blanket Building. This building houses facilities to support radiation monitoring and worker protection functions.

- Backup Power Building - The Backup Power Building is a reinforced-concrete building. This structure contains the three diesel generators and backup power equipment. All generators are located in a hardened structure capable of withstanding PC3 loads. The diesel and generator sit on a 12-in. pedestal to keep spills away from the equipment. One 5000 -gal diesel storage tank is provided for each diesel.

- Operations Building - The Operations Building is a building with structural steel frame on reinforced-concrete footings and slab. This building is the center of the tritium production center, providing operational control and monitoring of the accelerator target/blanket assembly, tritium separation facility, and associated support and safety systems. This building housing personnel responsible for maintaining the desired production level of tritium.

- Warehouse Building - The warehouse is a pre-engineered steel frame on reinforced-concrete slab. This warehouse provides levels A, B, C, and D storage of equipment, spares, and materials. This warehouse allows trucks to load and unload equipment to the facility.

- Maintenance Building - The Maintenance Building is a one-story building enclosing a $6 \mathrm{~m}$ high bay area for maintenance/storage and offices and personnel support facilities. This building provides shop and service areas for performing maintenance, calibration, and assembly/disassembly activities of all accelerator, target/blanket, and processing system components, including klystron refurbishment and contaminated equipment maintenance. It will also provide warehousing and materials handling for consumable goods and spare parts for these systems.

- Klystron Maintenance Facility - This building is linked to one end of the Klystron Gallery to minimize moving efforts for klystrons in need of repair. This facility provides various stations and equipment for repair of klystrons and maintenance of RF windows. These stations include receiving area, disassembly area, cutting area, inspection/cleaning area, 
assembly area, welding area, baking area, connections area containing oil/water spill capabilities, Klystron testing area, Klystron storage area, and office areas, etc.

- Cooling Tower Structures - Cooling tower structures are vendor-provided fiberglass structures that sit over $2 \mathrm{~m}$ deep basins. A pumping structure is located at one end of the basin and supports the circulation pumps. Cooling tower systems are provided for the TSF, accelerator, Klystron Cooling Stations 1 through 9, Cryogenics Facilities 1 through 3, Klystron Remanufacturing Facility, T/B heat removal, and beamstop heat removal.

- Mechanical Support Buildings - These facilities include components for HVAC and heat removal. Mechanical Support Buildings house circulation pumps, heat exchangers, water chillers, expansion tanks, and pressurization pumps. Primary heat exchangers of cooling water systems associated with components in the Accelerator Tunnel are enclosed in concrete structures to provide radiation shielding.

- Simulator and Training Building - The simulator control room facility provides operator training and examination and will be used throughout the plant life-cycle to evaluate and develop new operational procedures. The building will also serve as a receiving and training location for new employees and as a visitors center for the public.

- Fire Pump House and Water Storage Tanks - The Fire Pump House is a reinforced-concrete masonry structure with a reinforced-concrete mat foundation. The pump house contains fireprotection equipment to support the APT facility. This includes primary and secondary diesel-powered pumps to provide flow to the various facility fire-protection systems. The water storage tanks will hold water above ground to support the fire-protection system.

- Demineralizer Building - The Demineralizer Building is a structural-steel building with a reinforced mat foundation. This building houses fixtures and equipment for treatment and supply of make-up water for use in the closed-loop cooling water systems. The fixtures and equipment include the caustic storage tank, unloading pump, and metering pumps; acid storage tank, unloading pump, and metering pumps; cation exchangers; degasifiers; anion exchangers; and mixed-bed polisher.

- Security Building - The Security Building is a reinforced-masonry or -concrete structure with heating and ventilation facilities. This building houses security personnel and facilities to control access and monitor the APT facility.

Site and Buildings Waste Streams 
Most of the waste generated by the support or balance of plant facilities will be non-hazardous and non-radioactive. Several of the waste stream possess potential for being hazardous, radioactive or mixed waste. Personal protective equipment (PPE) from routine maintenance is one of the major sources of APT radioactive wastes.

The administration building and operations building will generate paper and other sanitary solid waste. Waste documents of a sensitive nature would need be shredded or sent to classified scrap. In addition, a variety of nonradioactive nor hazardous wastes will be generated from building maintenance, HVAC maintenance, office operations, lunch rooms, and maintenance of vehicles.

Wastes from the support or balance of plant facilities are included in the following waste streams described in Appendix B.

B1. Job Control Waste

B2. Job Control Waste (Mixed Low-Level Waste)

B3e. HEPA filters

B5. Mixed and Hazardous Waste Oil/Solvent

B6. Mixed Waste Solvent Rags

B11. Radioactive Light Water and Aqueous Solutions

B14. Sanitary and Industrial Waste 


\section{APPENDIX B}

\section{APT Waste Streams}

Appendix B contains a list of solid, liquid, and air waste streams for the APT to include hazardous components, radioactive contamination, or both (mixed waste). This appendix identifies and addresses hazardous, low-level, intermediate-level, and mixed low-level waste streams. The waste streams are identified based on the conceptual APT processes and anticipated operations described in Appendix A. The PWA also addresses all possible design outcomes, such as room temperature and LiAl, in support of the APT EIS. Current SRS operating practice requires individual waste characterization plans to be developed for each lowlevel and mixed low-level waste stream. These waste characterization plans must be approved before waste may be shipped to the Solid Waste Management Division.

Each waste stream description contains the following information:

Type: Identifies a solid waste stream as either hazardous waste, low-level radioactive waste (LLRW), intermediate-level waste or mixed low-level waste (MLLW). Intermediate-level waste is a subset of low-level waste; it is used to designate low-level waste emitting greater than 200 $\mathrm{mRad} / \mathrm{hr}$ closed window reading at $5 \mathrm{~cm}$ from the container surface. Radioactive liquid waste streams are also identified. No high-level or transuranic (TRU) waste will be generated by the APT.

Definitions of low-level radioactive waste and hazardous waste are given below. Mixed waste is waste that is both radioactive and hazardous. This gives categories of mixed low-level waste, mixed high-level waste, and mixed TRU waste.

Low level radioactive waste (LLRW) is defined by the Low-level Radioactive Waste Policy Amendments Act as radioactive waste that is not:

- High-level radioactive waste

- Spent nuclear fuel

- Byproduct material as defined in section $11 E(2)$ of the Atomic Energy Act (uranium or thorium mill tailings)

NRC classifies LLRW based on the radionuclide content of the waste (10CFR61.55). $L L R W$ is classified as either $A, B$ or $C$ based on the long-and short-lived radioactive materials in the waste.

A hazardous waste is a solid waste not excluded from regulation and either:

- Listed as hazardous under CFR261.31-33 
Nonspecific source hazardous materials include spent solvents, electroplating wastes, metal heat-treating waste, chlorinated aliphatic manufacturing residues and waste from the production or manufacturing of chlorophenolics. Specific source wastes include:

- Inorganic chemicals (waste water sludges, process residue, wastewaters)

- Secondary lead (emission control dust/sludge, waste leaching solution)

- Ink formulation (wastewater, solvent washes and sludges, wastewater treatment sludges)

- Wood preservation (wastewater treatment sludges)

- Inorganic pigments (wastewater treatment sludges, process residues)

- Organic chemicals (still bottoms, spent catalysts, process residue)

- Pesticides (wastewater treatment sludges, filter solids, still bottoms, byproduct salts, wastewaters)

There are 318 commercial products listed as hazardous: 216 hazardous (U-list) and 102 acutely hazardous ( $P$-list).

- Mixed with a listed hazardous waste

- Exhibits any of the four characteristics of ignitability (D001), corrosivity (D002), reactivity (D003) or EPA toxicity (D004-D014).

- Derived from the Storage, Treatment or Disposal of a hazardous waste, including:

- Sludges

- Treatment residue

- Ash

- Air emission control sludge/dust

- Leachate

A solid waste is any discarded material, in solid, liquid or gas form, not excluded by 40CFR261.4(a) or in the variance granted under 40CFR260.30-31. Discarded materials include materials that are abandoned, considered inherently waste-like or recycled. The following are excluded under 40CFR261.4(a) and are not considered solid wastes:

- Domestic sewage

- Waste discharged via public sewer to a publicly-owned treatment works

- Point source discharges subject to NPDES

- Irrigation return flows

- Waste subject to the Atomic Energy Act of 1954

- Wastes from in situ mining (when not removed from the ground)

- Unless accumulated speculatively,

- reclaimed pulping liquors that are re-used

- spent sulfuric acid used to produce virgin sulfuric acid 
Description: Gives the waste stream physical matrix, EPA hazardous waste codes of RCRA components that may be present, source of radioactive contamination, radioactive isotopes and/or activity levels present.

Generation: Describes the process or activity generating the waste stream.

Handling and Packaging: Describes the current or recommended handling techniques and packaging practices for the waste stream to meet applicable Waste Management Facility Waste Acceptance Criteria (WAC).

Annual Quantities: Gives estimated annual generation rates in mass and volume. Quantities are based on the experience of DOE facilities with similar operations or using similar components, anticipated levels of production activities and/or engineering judgment. For reference, SRS Tritium Facilities actual waste shipped in FY96 and forecasted FY97-98 waste shipments (exclusive of Non-Nuclear Reconfiguration Project waste) are presented in Table B1.

Waste Minimization: Lists recommended methods for reducing or eliminating the waste stream. For potential mixed waste, lists recommendations for eliminating the hazardous component.

Treatment Options: Lists possible treatment technologies for LLRW or MLLW. Descriptions of the listed treatment technologies are given in Appendix C. It is assumed non-combustible hazardous waste not incinerated in the Consolidated Incineration Facility (CIF) will be treated and packaged for disposal at a DOE-approved DOE or commercial waste management facility.

Comments: Provides additional information, not fitting in the other categories, to help understand the nature of the waste stream or its treatment.

All defined waste streams have been identified in this Appendix. Several waste streams have been subdivided to provide for expanded discussions of the waste stream components. DOE Order 6430.1 states radioactive mixed waste shall be avoided where practical and mixed waste that cannot be avoided shall be identified and considered in the facility design at the earliest possible time. In this Appendix, the identified mixed waste streams are associated with the production of neutrons and cannot be avoided. The projected waste generation quantities for these mixed waste streams may be reduced further in practice based on operational experience in the production accelerator.

\section{APT Waste Stream Assumptions}

1. Estimates based on a facility population of 650 people, where applicable.

2. No hazardous oils, paints, or hydraulic fluids will be used at the APT facility. 
3. TSCA Waste - assessment put on hold until a determination of the APT related activities to take place in the M-Area of the SRS.

4. Based on an APT production of $3 \mathrm{~kg} / \mathrm{yr}$ of Tritium.

5. Estimates are based on a Helium-3 and LiAl target design.

6. Wastes resulting from Klystron and LINAC remanufacturing operations are included in these estimates.

7. Values are based on engineering assessment, APT design data, and previous published references (e.g., Site Treatment Plan, programmatic EIS, etc.).

8. Based on a room temperature and superconducting APT configuration.

9. RCRA material shall be separated to the maximum extent economically feasible from nonRCRA materials to reduce the volume and mass of the waste to be handled as mixed waste. The mixed waste estimates take this into consideration.

10. A B-25 container is nominally $2.5 \mathrm{~m}^{3}$

11. A 21 " cubic cardboard box has a volume of $5.4 \mathrm{ft}^{3}$

12. Administrative limit of $50 \mathrm{lb}(22 \mathrm{~kg})$ in 21 " $22 \mathrm{l}$ " $\mathrm{2} 2 \mathrm{l}$ " box $\left(5.4 \mathrm{ft}^{3}\right) \Rightarrow 9.3 \mathrm{lb} / \mathrm{ft}^{3}$ bulk density before compaction. 


\section{B1. Job Control Waste}

\section{Type: Low-Level Radioactive Waste}

Description: Job Control Waste (JCW) is the predominant low-level waste stream by volume. JCW normally contains personal protective equipment (PPE) such as shoe covers, gloves, plastic suits, and air hoses. Other JCW includes kraft paper, sheet plastic, rags, absorbent wipes, tape used for radiological control, small equipment parts such as o-rings, gaskets, pipe fittings, broken glass test tubes and beakers. Items will be contaminated with trace to significant amounts of the radionuclides listed in waste streams $\mathrm{B} 3, \mathrm{~B} 3 \mathrm{a}, \mathrm{B} 3 \mathrm{~b}, \mathrm{~B} 3 \mathrm{c}, \mathrm{B} 3 \mathrm{~d}, \mathrm{~B} 4, \mathrm{~B} 9, \mathrm{~B} 11, \mathrm{~B} 12, \mathrm{~B} 15, \mathrm{~B} 16, \mathrm{~B} 17$, $\mathrm{B} 18$, and $\mathrm{B} 21$. The actual radionuclides and concentration will vary depending where in the APT facility the JCW is generated.

Generation: Job Control Waste is generated during production, maintenance, decontamination or housekeeping activities in the APT radioactive areas. Job Control Waste is collected from all contaminated areas, with the exception of the LiAl extraction area (LiAl extraction JCW is covered under a separate waste stream.). Tritium diffusion into cellulose and plastic materials is usually negligible, due to the absence of a strong driving force (high temperature or tritium partial pressure). Once an item is contaminated, tritium and other contaminants may diffuse throughout the material. However, the total amount of radionuclides in the material will not increase as a result of diffusion.

Handling and Packaging: Depending upon activation, tritium and spallation product content, this waste stream is segregated into incinerable, compactible or non-compactible fractions based on waste form and the contamination level of the location where the waste was generated. Plastic and cellulose items and most small metal items will be incinerated in the CIF. Incinerable or compactible waste, after bagging, is monitored for detectable offgassing tritium (greater than $4 \mathrm{E}-5$ $\mu \mathrm{Ci} / \mathrm{cc}$ ). To ensure that this criterion is maintained, waste from areas with tritium contamination greater than $3.7 \mathrm{E}+6 \mathrm{dpm} \mathrm{H}-3 / 100 \mathrm{~cm}^{2}$ is segregated. Incinerable or compactible waste is packaged in 21 " $\times 21$ "x21" cardboard radioactive waste boxes that are in good condition, and lined with a plastic bag. When a bag is full, it is monitored for offgassing tritium and surveyed for external surface contamination before shipment. Non-incinerable waste is placed in yellow or yellow-striped clear plastic radioactive waste bags. Closed waste packages are surveyed for offgassing tritium and for external contamination before being transferred to a B-25 box. Partially filled B-25 boxes are locked or stored inside the APT Radwaste Facility. Once a B-25 box is filled, it is closed and manifested for transportation to the E-Area Vaults (EAV) Low Activity Waste (LAW) Vaults for disposal. 
Annual Quantities:

\begin{tabular}{|c|r|r|}
\hline Waste Destination & Volume & Mass \\
\hline CIF & $500 \mathrm{~m}^{3}$ & $65,000 \mathrm{~kg}$ \\
\hline Compaction/LAW Vaults & $75 \mathrm{~m}^{3}$ & $10,000 \mathrm{~kg}$ \\
\hline Direct to LAW Vaults & $425 \mathrm{~m}^{3}$ & $55,000 \mathrm{~kg}$ \\
\hline
\end{tabular}

(a) Assume $50 \%$ to $\mathrm{CIF}, 25 \%$ to Compaction/LAW Vaults, $25 \%$ directly to LAW Vaults,

(b) Administrative limit of $50 \mathrm{lb}(22 \mathrm{~kg})$ in 21 "x 21 " 21 " box or $5.4 \mathrm{ft}^{3}=>9.3 \mathrm{lb} / \mathrm{ft}^{3}$ bulk density before compaction.

Waste Minimization:

(a) Process design changes can eliminate the potential for spills or pooling of cleaning solutions. Glovebox operation also eliminates the need for plastic suits, air hoses, etc., during maintenance and line breaks.

(b) Product substitution. For example, SRS evaluated the use of polyester wipes as a substitute for a product previously used in a variety of cleaning/decon situations. The polyester wipes were found to reduce the volume of generated wastes without diminishing performance and have been adopted for site-wide use.

\section{Treatment Options:}

(a) Incineration at CIF, followed by cement stabilization of ash/residue. Disposal of stabilized ash in the E-Area Vaults if passes TCLP; storage as mixed waste for further treatment if waste fails TCLP.

(b) Compaction for disposal in the EAV LAW Vaults.

(c) Direct disposal in the EAV LAW Vaults.

\section{Comments:}

(a) In a 1992 PWA, absorbent wipes made up $1 \%$ of a total waste of $25,457 \mathrm{ft}^{3}\left(721 \mathrm{~m}^{3}\right)$ at the SRS tritium processing facility (Ref: WSRC, "1992 Process Waste Assessment, Tritium Facility Low-level Waste," NMP-STE-93138, 8/13/93). Waste stream characteristics were estimated on the basis of purchasing records, observation of sample waste-handling activities, and interviews with operations personnel. 
Table B1. SRS Tritium Facilities FY97-98 Waste Forecast*

For Reference use

(Volumes in $\mathbf{f t}^{\mathbf{3}}$ )

\begin{tabular}{|c|c|c|c|c|c|}
\hline & $\begin{array}{c}\text { Waste } \\
\text { Management } \\
\text { Facility } \\
\end{array}$ & $\begin{array}{c}\text { FY96 } \\
\text { (Actual) }\end{array}$ & FY97 & FY98 & Comments \\
\hline \multicolumn{6}{|l|}{ EXTRACTION (232-H) } \\
\hline Crucibles & ILTV Silos & $\mathbf{0}$ & 490 & 140 & $\begin{array}{l}35 \mathrm{f}^{3} / \text { crucible; } 14 \\
\text { in FY97; } \\
4 \text { in FY98. }\end{array}$ \\
\hline Nonhazardous Equipment & $\begin{array}{l}\text { ILTV Bulk } \\
\text { Cell }\end{array}$ & 120 & 1,343 & 461 & $\begin{array}{l}\text { Includes } 150 \mathrm{LP}- \\
50 \text { storage } \\
\text { containers }(1103 \\
\left.\mathrm{ft}^{3}\right)\end{array}$ \\
\hline $\begin{array}{l}\text { Job Control \& } \\
\text { Nonhazardous Equipment }\end{array}$ & LAW Vaults & 390 & 970 & 620 & $\begin{array}{l}700 \mathrm{ft}^{3} \text { of tritiated } \\
\text { secondary } \\
\text { containers in } \\
\text { FY97 }\end{array}$ \\
\hline Job Control & $\mathrm{CIF}$ & 0 & 180 & 180 & \\
\hline Hazardous Waste & $\mathrm{CIF}$ & 5 & 49 & 16 & Methanol rags \\
\hline Mixed low-level & $\begin{array}{l}\text { Interim } \\
\text { Storage }\end{array}$ & 15 & 15 & 7 & $\begin{array}{l}\text { Freon rags from } U \\
\text { bed preparation }\end{array}$ \\
\hline \multicolumn{6}{|l|}{ H-3 PURIFICATION } \\
\hline $\begin{array}{l}\text { Job Control } \\
(232-\mathrm{H}, 233-\mathrm{H}, 234-\mathrm{H}, 238-\mathrm{H})\end{array}$ & LAW Vaults & 14,500 & 10,500 & 10,500 & \\
\hline $\begin{array}{l}\text { Job Control } \\
(232-\mathrm{H}, 233-\mathrm{H}, 234-\mathrm{H}, 238-\mathrm{H})\end{array}$ & $\mathrm{CIF}$ & 6,500 & 10,500 & 10,500 & \\
\hline $\begin{array}{l}\text { Nonhazardous Equipment } \\
(232-\mathrm{H}, 233-\mathrm{H}, 234-\mathrm{H})\end{array}$ & $\begin{array}{l}\text { ILTV Bulk } \\
\text { Cell }\end{array}$ & 1,980 & 2,835 & 2,475 & $\begin{array}{l}\text { Includes U beds, } \mathrm{Mg} \\
\text { beds, and } \mathrm{Z} \text { beds }\end{array}$ \\
\hline $\begin{array}{l}\text { Chiller Oil } \\
(232-\mathrm{H}, 233-\mathrm{H})\end{array}$ & CIF & 0 & 162 & 0 & $\begin{array}{l}\text { Halogens too high } \\
\text { for Power House }\end{array}$ \\
\hline $\begin{array}{l}\text { Tritiated Waste Oil } \\
(232-\mathrm{H}, 233-\mathrm{H}, 234-\mathrm{H})\end{array}$ & LAW Vaults & 0 & 88 & 88 & $\begin{array}{l}\text { Includes stored and } \\
\text { new waste oil }\end{array}$ \\
\hline $\begin{array}{l}\text { Hazardous Solvent } \\
(249-\mathrm{H})\end{array}$ & $\begin{array}{l}\text { Interim } \\
\text { Storage }\end{array}$ & 7 & 7 & 7 & $\begin{array}{l}\text { CFC-11 solvent \& } \\
\text { oil }\end{array}$ \\
\hline $\begin{array}{l}\text { Mixed Waste Equipment } \\
(232-\mathrm{H}, 233-\mathrm{H}, 234-\mathrm{H})\end{array}$ & $\begin{array}{l}\text { Interim } \\
\text { Storage }\end{array}$ & 90 & 100 & 100 & $\begin{array}{l}\mathrm{Hg} \text { and } \mathrm{Pb} \\
\text { contaminated }\end{array}$ \\
\hline Mixed Oil (232-H, 234-H) & $\begin{array}{l}\text { Interim } \\
\text { Storage }\end{array}$ & 45 & 77 & 22 & $\mathrm{Hg}$ contaminated \\
\hline Mixed Job Control (233-H) & $\begin{array}{l}\text { Interim } \\
\text { Storage }\end{array}$ & 0 & 0 & 5 & Methanol rags \\
\hline Mixed Freon Rags $(234-\mathrm{H})$ & $\begin{array}{l}\text { Interim } \\
\text { Storage }\end{array}$ & 0 & 32 & 0 & \\
\hline
\end{tabular}

*This table excludes waste forecast from the Non-Nuclear Reconfiguration Project. This table is included for reference to TSF waste generation rates. 
Note: A B-25 container is nominally $90 \mathrm{ft}^{3}$ and a 21 " cubic cardboard box has a volume of $5.4 \mathrm{ft}^{3}$ 


\section{B1a. Nonhazardous Solvents}

Type: Low-level Radioactive Waste.

Description: Residues of solutions used for decontamination, cleaning, or degreasing during equipment maintenance or repair. The solvents may become contaminated with radioactive or hazardous materials during the cleaning process. Items will be contaminated with trace to significant amounts of the radionuclides listed in waste streams B3, B3a, B3b, B3c, B3d, B4, B9, $\mathrm{B} 11, \mathrm{~B} 12, \mathrm{~B} 15, \mathrm{~B} 16, \mathrm{~B} 17, \mathrm{~B} 18$, and $\mathrm{B} 21$. The actual radionuclides and concentration will vary depending where in the APT facility the JCW is generated.

Generation: Routine maintenance, cleaning, degreasing, and decontamination activities.

Handling and Packaging: Pour onto rags and combine with Waste Stream B1.

Annual Quantities: Included in Waste Stream B1.

Waste Minimization:

(a) Change to mechanical/physical stripping/cleaning devices to avoid solvent use.

(b) Solvent recovery and distillation

Treatment Options:

(a) See Waste Stream B1.

(b) Reclamation by an off-site vendor (e.g., Safety-Kleen)

Comments:

None. 


\section{B2. Job Control Waste (Mixed Low-Level Waste)}

Type: Mixed Low-level Radioactive, Hazardous

Description: See Waste Stream B1. Methanol and Freon are possible hazardous contaminants. Many instrument computer boards also contain RCRA metals. Items will be contaminated with trace to significant amounts of the radionuclides listed in waste streams B4, B9, B11, and B12. The actual radionuclides and concentration will vary depending where in the APT facility the JCW is generated.

Generation: See Waste Stream B1.

Handling and Packaging: See Waste Stream B1.

Annual Quantities:

\begin{tabular}{|c|r|r|}
\hline Waste Destination & Volume & Mass \\
\hline Interim Storage/Off-site & $0.5 \mathrm{~m}^{3}$ & $100 \mathrm{~kg}$ \\
\hline $\mathrm{CIF}$ & $0.5 \mathrm{~m}^{3}$ & $100 \mathrm{~kg}$ \\
\hline
\end{tabular}

Waste Minimization: See Waste Stream B1.

\section{Treatment Options:}

(a) Incineration at CIF for solvent rags, followed by cement stabilization of ash/residue.

(b) Thermal desorption followed by storage or disposal.

\section{Comments:}

(a) If listed material is incinerated, residue must be stabilized and disposed in a RCRA Subtitle $C$ facility.

(b) While thermal desorption of volatile organics may convert a mixed waste to a low-level waste, if the off-gases are adsorbed on activated carbon, this becomes a secondary waste stream. 


\section{B3. Nonhazardous Process Equipment}

Type: Low-level Radioactive Waste

Description: This waste stream consists of discarded process equipment or parts from radiation areas of APT. It includes equipment such as vessels, tanks, heat exchangers, accelerator components, pressure gauges, valves, fittings and secondary containers. Minor maintenance parts (e.g., small gaskets, bolts) are managed as Job Control Waste. All process equipment is non-incinerable and non-compactable due to physical form and potential radioactive offgassing. Component radioactive content may be assigned based on experimentally determined correlation's (e.g., $0.05 \mathrm{Ci}$ of tritium per square foot of tritium-exposed surface.). Items will be contaminated with trace to significant amounts of the radionuclides listed in waste streams B9, $\mathrm{B} 11, \mathrm{~B} 12, \mathrm{~B} 15, \mathrm{~B} 16, \mathrm{~B} 17, \mathrm{~B} 18$, and $\mathrm{B} 21$. The actual radionuclides and concentration will vary depending where in the APT facility the process equipment is utilized.

Generation: Nonhazardous Process Equipment waste is generated by preventive and corrective maintenance of the APT radioactively contaminated areas.

Handling and Packaging: To the extent practical tritium is removed from waste process equipment by flushing with purge gas or heating. Following removal from the process system and glovebox, waste equipment is stored to control offgassing tritium and spallation products within a monitored ventilation system. Management will review offgassing rate and facility conditions to determine when to dispose of process equipment. Following a period of offgassing, the equipment will be placed into pre-approved containers (such as B-12 containers) for transport to the E-Area Vaults.

Annual Quantities:

\begin{tabular}{|c|r|r|}
\hline Waste Destination & Volume & Mass \\
\hline LAW Vaults & $300 \mathrm{~m}^{3}$ & $408,000 \mathrm{~kg}$ \\
\hline ILTV Bulk Cell & $50 \mathrm{~m}^{3}$ & $68,000 \mathrm{~kg}$ \\
\hline
\end{tabular}

(a) Assume $75 \%$ void space, 50 vol \% aluminum (2.7 SpG), 50 vol \% stainless steel $(8.0$ $\mathrm{SpG})=>90 \times 0.25 \times 62.3 \times(0.5 \times 2.7+0.5 \times 8) \sim 7,430 \mathrm{lb} \Rightarrow \sim 1360 \mathrm{~kg} / \mathrm{m}^{3}$

Waste Minimization:

(a) Use reliability centered maintenance to extend process equipment life.

(b) Decontaminate equipment and/or recycle metal. 
(c) Use volume reduction techniques (cutting, compaction, etc.) to minimize final waste volume. 
Treatment Options:

(a) Thermal desorption to remove as much tritium and contaminants as practical.

(b) Offgassing controlled to protect handling personnel.

(c) Depending on nuclide content, waste equipment will be disposed of in either the LAW Vaults, the ILTV Bulk Cell, or TBD.

(d) For other contaminants surface decontamination as required.

Comments: None: 


\section{B3a. Uranium/Magnesium Beds}

Type: Low-level Radioactive Waste.

Description: Uranium beds currently in use at SRS are about four feet long and two feet in diameter. The bed material is initially turnings of depleted uranium, but as the bed is used the material is oxidized to uranium oxide. Similarly, magnesium bed material is initially magnesium metal filings that oxidize to magnesium oxide as the bed is used.. Spent depleted uranium beds also contain isotopes of uranium that must be manifested. All types of spent beds will be contaminated with tritium. He-3 spallation products may also be present in some of these beds. The design generally will preclude spallation products from contaminating most, if not all, of these beds.

Generation: 1) Uranium or magnesium beds are used to "crack" moisture in the process gas to elemental hydrogen isotopes. The reaction involves water reacting with uranium to form an oxide and release hydrogen isotopes. The cracked gas then undergoes further gas separation to produced purified tritium. 2) In the Z-bed Recovery process, uranium or magnesium is consumed while cracking tritiated water to recover tritium adsorbed as tritiated water on zeolite beds. The zeolite beds are regenerated for reuse by heating and recirculating a carrier gas, which carries desorbed water or hydrogen oxides to heated uranium or magnesium beds. The hydrogen oxides react with uranium or magnesium to form an uranium or magnesium oxide and release hydrogen isotopes. This mixture of hydrogen isotopes again undergoes isotopic separation.

\section{Handling and Packaging:}

The outer bed surface is decontaminated and the beds are bagged for disposal in a B-12 container for shipment to the EAV Intermediate Level Tritium Vaults Bulk Cell.

\section{Annual Quantities:}

\begin{tabular}{|c|r|r|}
\hline Waste Destination & Volume & Mass \\
\hline $\begin{array}{c}\text { U Beds to ILTV Bulk } \\
\text { Cell }\end{array}$ & $2.8 \mathrm{~m}^{3}$ & $14,500 \mathrm{~kg}$ \\
\hline $\begin{array}{c}\text { Mg Beds to ILTV Bulk } \\
\text { Cell }\end{array}$ & $5.6 \mathrm{~m}^{3}$ & $3,700 \mathrm{~kg}$ \\
\hline
\end{tabular}

(a) Assume four beds in APT (two sets of two beds in parallel), and replacing 2 beds every quarter or 8 beds per year.

(b) Assume each U bed is 2 feet O. D . $x 4$ feet long $\Rightarrow 12.6 \mathrm{ft}^{3}$. 
(c) Assume 75\% void space, uranium $(\mathrm{SpG}=19) \Rightarrow>-3,700 \mathrm{lb}$ each $\mathrm{U}$ bed.

(d) Assume 24" Schedule 10 steel pipe container $(63.4 \mathrm{lb} / \mathrm{ft}) \Rightarrow \sim 250 \mathrm{lb}$. Plus $50 \mathrm{lb}$ for ends gives $\sim 300 \mathrm{lb}$ for total container weight. Total $\mathrm{U}$ bed weight $\sim, 000 \mathrm{lb}$ each.

(e) Assume $\mathrm{Mg}$ beds are sized $2 \mathrm{x}$ for same duty $=>25 \mathrm{ft}^{3} / \mathrm{Mg}$ bed.

(f) Assume $75 \%$ void space, magnesium ( $\mathrm{SpG}=1.7) \Rightarrow 660 \mathrm{lb}$ of $\mathrm{Mg}$ in each $\mathrm{Mg}$ bed.

(g) Assume 24" Schedule 10 steel container weighs $\sim 340 \mathrm{lb}$ each=>1,000 lb/loaded Mg bed.

\section{Waste Minimization:}

(a) Use of $\mathrm{Mg}$ beds is preferred over $\mathrm{U}$ beds for waste minimization; much less job control waste is generated in using the $\mathrm{Mg}$ beds.

(b) Investigate alternative $z$-bed regeneration technologies using palladium membrane reactor, regenerable iron oxide beds or solid oxide electrolysis.

\section{Treatment Options:}

Waste uranium or magnesium beds are sealed, self-contained units that can be packaged in gloveboxes under a nitrogen atmosphere for disposal. However, the uranium or magnesium must be completely oxidized to destroy its ignitability characteristic to meet disposal Waste Acceptance Criteria.

\section{Comments:}

SRS Tritium Facilities operating personnel prefer magnesium beds over uranium beds and are in the process of replacing the remaining uranium beds in $233-\mathrm{H}$ to magnesium beds. While uranium and uranium oxide are not hazardous listed materials under RCRA, the depleted beds are a fire hazard because the finely divided powder that forms can ignite spontaneously in air. Magnesium beds are somewhat less reactive, but similar precautions should be used. 


\section{B3b. Hydride/Catalyst/Zeolite Beds}

Type: Low-level Radioactive Waste.

Description: Hydride storage beds (e.g., LANA beds) currently in use at SRS are 4" in diameter and 3 feet long per unit. They have an inner container made of 3" Schedule 40 stainless steel and an outer container made of 4 " Schedule 10 stainless steel. Each unit has about 45 pounds of stainless steel in the container and 15 pounds of metal hydride material in the bed. LANA metal hydride storage bed packing material contains nickel, which is under heavy scrutiny as an environmental hazard and is on some state lists as a hazardous material. Waste hydride beds will contain approximately $100 \mathrm{Ci}$ per bed of residual tritium.

Platinum/Alumina catalyst beds consist of pellets of finely dispersed platinum metal on an alumina substrate. Alumina is aluminum oxide, $\mathrm{Al}_{2} \mathrm{O}_{3}$, which is non-combustible and non-toxic. Waste catalyst beds will be contaminated with tritium.

Other small hydride getter beds that may be used in TSF systems could contain SAES St198 $\left(\mathrm{Zr}_{2} \mathrm{Fe}\right), \mathrm{Ti}$, TiVFe, $\mathrm{ZrVFeTi}$, or $\mathrm{ZrFe} \mathrm{Sn}$ as possible getter materials.

Zeolite is either a naturally hydrated silicate of aluminum and either sodium or calcium or both, of the type $\mathrm{Na}_{2} \mathrm{O} \mathrm{Al}_{2} \mathrm{O}_{3} \mathrm{nH}_{2} \mathrm{O}$; or an artificial ion exchange resin. Artificial zeolites are made in a variety of forms, ranging from gelatinous to porous and sand-like, and are used as gas adsorbents, water softeners, drying agents, and catalysts. Molecular sieves are a group of adsorptive desiccants which belong to the zeolite family. The outstanding characteristic of these materials is their ability to undergo dehydration with little or no change in crystal structure. The dehydrated crystals are interlaced with regularly spaced channels of molecular dimensions that comprise almost $50 \%$ of the total volume of the crystals. The empty cavities in an activated molecular sieve have a strong tendency to recapture the water molecules that have been driven off. Waste zeolite beds are containerized molecular sieve beads or pellets contaminated with tritium.

Generation: LANA hydride beds currently in use for storing tritium have a tendency to trap the helium-3 decay product of tritium. It is assumed that helium buildup will eventually lead to hydride bed failure and need for replacement. The expected LANA hydride bed lifetime is about five years.

Stripping systems are used to recover tritium from waste gases before they are sent to the stack. These stripper systems operate by pumping the gas over a heated Pt/Alumina catalyst bed (Engelhard Deoxo D) to oxidize the molecular hydrogen isotopic species to tritiated water. The resulting tritiated water, regular water, and HTO are then adsorbed by the molecular sieve in the zeolite beds. The molecular sieve can be regenerated and reused until a physical breakdown in the 
material necessitates its replacement. At that time the entire unit, the container and the molecular sieve, will be replaced.

Handling and Packaging: Tritium is removed from waste hydride/catalyst/zeolite equipment by flushing with purge gas, heating, and/or isotopic exchange. Hydride and catalyst beds need to be passivated and isolated. Following removal from process, process equipment may be stored in engineered air hoods or gloveboxes to control offgassing tritium within a monitored ventilation system. Management will review offgassing rate and facility conditions to determine when to dispose of process equipment. Following a period of off-gassing, spent beds are wrapped in plastic bags (heavy duty polyurethane) and placed into pre-approved containers (e.g., B-12 containers) for disposal in the E-Area Vaults.

\section{Annual Quantities:}

\begin{tabular}{|c|r|r|}
\hline Waste Destination & Volume & Mass \\
\hline $\begin{array}{c}\text { Hydride Beds to LAW } \\
\text { Vaults }\end{array}$ & $0.14 \mathrm{~m}^{3}$ & $55 \mathrm{~kg}$ \\
\hline
\end{tabular}

(a) Assume two hydride beds per year after 5 years of operation; no 233- $\mathrm{H}$ hydride bed has been disposed as waste after 5 years of RTF operation.

(b) Assume each jacketed hydride bed is 12 in $O$. D . $\times 3$ feet long $=>2.4 \mathrm{ft}^{3}$.

(c) Assume each bed is about $45 \mathrm{lb}$ container and $15 \mathrm{lb}$ metal hydride. Container weight check:

Outer container: 3 " Schedule 40 steel pipe $(7.6 \mathrm{lb} / \mathrm{ft}) \times 3 \mathrm{ft}=22.8 \mathrm{lb}$.

Inner container: 4" Schedule 10 steel pipe $(5.6 \mathrm{lb} / \mathrm{ft}) \times 3 \mathrm{ft}=16.8 \mathrm{lb}$.

(d) Assume no routine waste catalyst and $\mathrm{Z}$ beds; they are expected to last the design life of the APT of 40 years.

\section{Treatment Options:}

(a) Hydride and catalyst beds must be passivated to eliminate potential for spontaneous combustion. The entire containerized units are packaged for disposal without removing the packing materials.

(b) Zeolite beds are thermally desorbed to Z-Bed Recovery. Isotopic swamping or exchange may be desirable to recover tritium prior to disposal.

\section{Waste Minimization:}

(a) Maximize the use of direct recovery of tritium methods (such as getter beds to eliminate the oxide phase and associated need for a zeolite bed. 


\section{Comments:}

(a) The SRS Tritium Facilities currently has 10-15 hydride beds in use, with an estimated 2 to 3 beds requiring replacement each year. LANA hydride bed service life is expected to be 5 years or more.

(b) As they are cycled, metal hydrides become finely divided powders that are potentially pyrophoric.

(c) When metal hydrides are used for tritium capture and storage, it is uncertain whether the hydrides can reduce the tritium concentration in the waste gas to the 5 to 10 parts per million achieved during cryogenic distillation.

(d) In 233-H, type 3A zeolite is used in the Stripper System zeolite beds. Since zeolite $3 \mathrm{~A}$ does not adsorb $\mathrm{CO}_{2}$, the $\mathrm{CO}_{2}$ generated by the oxidation of organics goes out with the purge gas and does not accumulate in the zeolite beds.

(e) At TSTA the same molecular sieve was used for 10 years (not continuous use). The material was then replaced, not because of failure, but to investigate hold-up tritium on the bed. 


\section{B3c. Ion Exchange Resin Beds}

Type: Low-level Radioactive Waste.

Description: Spent containerized ion exchange resin used to purify water coolant in the heat removal systems of APT and the target pool. Radioactivity is present in the due to spallation and particulates and becomes deposited in the ion exchange resin during coolant slipstream purification. Items will be contaminated with trace to significant amounts of the radionuclides listed in waste streams B11 and B12. The actual radionuclides and concentration will vary depending upon the water polishing system the ion exchange resins are used.

Generation: The purification of heat removal systems and target pool coolant will be performed by processing a slipstream through filters and ion exchange resin to remove impurities.

Annual Quantities:

\begin{tabular}{|c|r|r|}
\hline Waste Destination & Volume & Mass \\
\hline $\begin{array}{c}\text { Ion Exchange Resins to } \\
\text { CIF }\end{array}$ & $2.5 \mathrm{~m}^{3}$ & $2850 \mathrm{~kg}$ \\
\hline $\begin{array}{c}\text { Ion Exchange Resins to } \\
\text { LAW Vaults }\end{array}$ & $2.5 \mathrm{~m}^{3}$ & $2850 \mathrm{~kg}$ \\
\hline
\end{tabular}

Waste Minimization:

(a) Dry storage of removed modules and components will eliminate the pool fraction of this waste stream.

(b) Series operation of two beds will ensure each bed is used to the point of saturation, minimizing resin waste volume.

Treatment Options:

(a) De-water the resins prior to disposal. De-watering service is available from SEG.

(b) Envirocare will accept de-watered resins for disposal.

(c) Incineration, followed by stabilization or vitrification of residue.

(d) Aging of $\mathrm{Be} 7$ resins of approximately 600 days eliminates radioactivity.

Comments: 
(a) In a typical design, after filtration, the coolant is processed through a pair of mixed bed ion exchangers. By providing for series operation, the resin in the first bed in the series can be fully utilized to minimize resin waste volume. The beds in each pair can be interconnected so that when the first bed saturates, inlet is switched to the second bed, the resin in the saturated bed is replaced, and it then becomes the new second bed.

(b) The use of RCRA metals in container construction will be avoided. 


\section{B3d. Palladium/Electrolysis Membrane}

Type: Low-level Radioactive Waste.

Description: Palladium membranes are used to separate impurity gases from hydrogen isotopes, without generating water. A palladium membrane reactor can also be used to recover tritium or hydrogen from waters or hydrogen oxides. Similarly, electrolysis is a technology that can be used for recovering elemental hydrogen isotopes from water vapors, without generating spent $\mathrm{Mg}$ or $\mathrm{U}$ bed waste. Waste palladium reactor/electrolysis membranes will be contaminated with tritium.

Generation: Equipment failure or replacement of failed parts/modules. This waste stream will only be generated if either the palladium membrane reactor or the solid oxide electrolysis technology is adopted to replace Z-bed recovery using a $\mathrm{Mg}$ bed or a $\mathrm{U}$ bed.

Annual Quantities:

\begin{tabular}{|c|r|r|}
\hline Waste Destination & Volume & Mass \\
\hline $\begin{array}{c}\text { Palladium Reactor/Electrolysis } \\
\text { Membranes to LAW Vaults }\end{array}$ & $0.14 \mathrm{~m}^{3}$ & $55 \mathrm{~kg}$ \\
\hline
\end{tabular}

(a) Assume two palladium reactor/electrolysis membranes per year after 5 years of operation.

(b) Assume each jacketed palladium reactor/electrolysis membranes bed is 12 in O. D . 33 feet long $\Rightarrow 2.4 \mathrm{ft}^{3}$

(c) Assume each palladium reactor/electrolysis membranes is about $45 \mathrm{lb}$ container and $15 \mathrm{lb}$ palladium reactor/electrolysis membranes. Container weight check:

Outer container: 3 " Schedule 40 steel pipe $(7.6 \mathrm{lb} / \mathrm{ft}) \times 3 \mathrm{ft}=22.8 \mathrm{lb}$.

Inner container: 4 " Schedule 10 steel pipe $(5.6 \mathrm{lb} / \mathrm{ft}) \times 3 \mathrm{ft}=16.8 \mathrm{lb}$.

Waste Minimization:

(a) Modular design to isolate potential failure elements, to avoid changing out the entire unit.

(b) Palladium membrane reactor and solid oxide electrolysis equipment should avoid use of RCRA metals in their construction.

Treatment Options:

Package for disposal in E-Area LAW Vaults. 
Comments: None. 


\section{B3e. HEPA Filters}

Type: Low-level Radioactive Waste.

Description: High-efficiency particulate air (HEPA) filters are filters capable of trapping and retaining at least 99.97 percent of all monodispersed particles $\geq 0.3 \mu \mathrm{m}$ in diameter. HEPA filters are generally made of a variety of paper and metallic materials. HEPA filters will be contaminated with trace to significant amounts of the radionuclides listed in waste streams B9, $\mathrm{B} 11, \mathrm{~B} 12, \mathrm{~B} 15, \mathrm{~B} 16, \mathrm{~B} 17, \mathrm{~B} 18$, and $\mathrm{B} 21$. The actual radionuclides and concentration will vary depending where in the APT facility the HEPA filters are generated.

Generation: Cavity Vessel, Accelerator gases, TSF gases, and stack gases are passed through HEPA filters, and the filters may require regular replacement.

Annual Quantities:

\begin{tabular}{|c|c|c|}
\hline Waste Destination & Volume & Mass \\
\hline HEPAs to LAW Vaults & $0.28 \mathrm{~m}^{3}$ & $55 \mathrm{~kg}$ \\
\hline
\end{tabular}

Waste Minimization:

A reusable HEPA filter is being developed.

\section{Treatment Options:}

Not applicable if reusable filters are used. Treatment for a conventional HEPA filter is a function of its composition; i.e., whether it is largely paper (thermal treatment) or metal (compaction). Since APT HEPA filters are assumed to be constructed of nonhazardous materials, they will be characterized and packaged for disposal, as appropriate.

Comments:

(a) HEPA filters will not prevent the release of tritium to the atmosphere. However, HEPA filters may be used to remove particulates containing tritium contamination.

(b) Carbon filters may be used in conjunction with HEPA filters to remove organics from stack gases. However, this would introduce an additional waste of spent carbon beds. 


\section{B3f. SAES St909 Beds}

Type: Low-level Radioactive Waste.

Description: SAES St909 (ZrMnFe compound) in an aluminum binder is another material used to crack water. The spent beds will be contaminated with tritium. He-3 spallation products may be present in the beds used in the gas process in the T/B Facility. The design generally will preclude spallation products from contaminating of these beds used in the Tritium Separation Facility (TSF).

Generation: SAES St909 beds are used to "crack" moisture in the process gas to elemental hydrogen isotopes. The cracked gas then undergoes further gas separation to produced purified tritium.

\section{Handling and Packaging:}

The outer bed surface is decontaminated and the beds are bagged for disposal in a B-12 container for shipment to the EAV Intermediate Level Tritium Vaults Bulk Cell.

\section{Annual Quantities:}

\begin{tabular}{|c|r|r|}
\hline Waste Destination & Volume & Mass \\
\hline $\begin{array}{c}\text { SAES St909 Beds to } \\
\text { ILTV Bulk Cell }\end{array}$ & $0.5 \mathrm{~m}^{3}$ & $250 \mathrm{~kg}$ \\
\hline
\end{tabular}

(a) Ten beds in the T/B Facility and ten beds in the TSF. Replace 1 bed per year.

(b) The actual beds are $\sim 13 \mathrm{~cm} \times 75 \mathrm{~cm}$. Each containerized for disposal SAES $5 t 909$ bed $\Rightarrow$ $-0.5 \mathrm{~m}^{3}$.

(c) $75 \%$ void space $\Rightarrow \sim 100 \mathrm{~kg}$ each bed.

(d) Steel pipe container $(63.4 \mathrm{lb} / \mathrm{ft})=>\sim 120 \mathrm{~kg}$. Plus $30 \mathrm{~kg}$ for ends gives $\sim 150 \mathrm{~kg}$ for total container weight. Total bed weight $\sim 250 \mathrm{~kg}$ each.

(e) ST 909 is actually $5 \mathrm{~kg}$ of this total.

Waste Minimization: TBD

Treatment Options: 
Waste SAES St909 beds are sealed, self-contained units that can be packaged in gloveboxes under a nitrogen atmosphere for disposal. The bed should be completely oxidized to minimize waste generation.

\section{Comments:}




\section{B3g. Spallation Metal Filter Assemblies}

Type: Low-level Radioactive Waste.

Description: Metal filter assemblies with 5 micron stainless frit in a small stainless assembly $(7.5 \mathrm{~cm} \times 15 \mathrm{~cm}) .$. The spent beds will be contaminated with tritium and $\mathrm{He}-3$ spallation products.

Generation: Their function is to assist in removing spallation products from the $\mathrm{He}-3$ gas stream in the T/B facility. There will be approximately twenty installed in the T/B facility.

Handling and Packaging:

The outer bed surface is decontaminated and the beds are bagged for disposal in a B-12 container for shipment to the EAV Intermediate Level Tritium Vaults Bulk Cell.

Annual Quantities:

\begin{tabular}{|c|r|r|}
\hline Waste Destination & Volume & Mass \\
\hline $\begin{array}{c}\text { Metal Filter Beds to } \\
\text { ILTV Bulk Cell }\end{array}$ & $0.4 \mathrm{~m}^{3}$ & $400 \mathrm{~kg}$ \\
\hline
\end{tabular}

(a) Twenty beds in the T/B Facility. Replace 4 beds per year.

(b) The actual beds are $\sim 7.5 \mathrm{~cm} \times 15 \mathrm{~cm}$. Each containerized bed for disposal $\Rightarrow \sim 0.1 \mathrm{~m}^{3}$.

(c) $75 \%$ void space $=>-20 \mathrm{~kg}$ each bed.

(d) Steel pipe container $(63.4 \mathrm{lb} / \mathrm{ft}) \Rightarrow>60 \mathrm{~kg}$. Plus $20 \mathrm{~kg}$ for ends gives $\sim 80 \mathrm{~kg}$ for total container weight. Total bed weight $\sim 100 \mathrm{~kg}$ each.

Waste Minimization:

(a) $\quad \mathrm{TBD}$

\section{Treatment Options:}

Waste metal filter beds are sealed, self-contained units that can be packaged in gloveboxes under a nitrogen atmosphere for disposal. The loading of radionuclides in these beds need to be determined in order to determine the disposal options for this wastestream.

Comments: 


\section{B3h. Accelerator Components Containing Niobum}

Type: Low-level Radioactive Waste.

Description: Accelerator components containing niobum. The components will be contaminated niobum 94 and other activation products.

Generation: Wastestream will be generated during maintenance and upgrade operations.

Handling and Packaging:

The outer surfaces are decontaminated and placed in packages for shipment to the APT radwaste facility.

Annual Quantities:

\begin{tabular}{|c|r|r|}
\hline Waste Destination & Volume & Mass \\
\hline Offsite/TBD & $1.0 \mathrm{~m}^{3}$ & $700 \mathrm{~kg}$ \\
\hline
\end{tabular}

Waste Minimization:

(a) Material substitution.

\section{Treatment Options:}

Wastes are packaged for transport, storage, and disposal. The loading of radionuclides in these beds need to be determined in order to determine the disposal options for this wastestream.

\section{Comments:}

The waste stream is expected to exceed the current WACs at DOE facilities for Nb-94 but will be below the GTCC limits. 


\section{B4. Palladium- Silver Permeator Waste Process Equipment}

Type: Mixed Low-level Waste

Description: Palladium-silver permeators currently in use at SRS are about two feet long and one foot in diameter. Silver is a hazardous material with RCRA code D011. During use the permeators will become contaminated with tritium.

\section{Average Hazardous Material Percentages \\ $\underline{\text { In Palladium-Silver Permeators }}$}

\begin{tabular}{|l|r|}
\hline Element & Average Percent \\
\hline $\mathrm{Cr}^{*}$ & $>1 \%$ \\
\hline $\mathrm{Ag}$ & $>1 \%$ \\
\hline $\mathrm{Cd}^{*}$ & $>1 \%$ \\
\hline
\end{tabular}

* incorporated in the stainless steel components of the beds and not expected to leach out.

Generation: Existing tritium processing at SRS uses palladium-silver alloy permeators to separate hydrogen isotopes from He-3 and He-4. A similar APT system will need two permeators. Experience at SRS indicates the permeators must be replaced after two or three years of service.

Generated by preventative and corrective maintenance of the tritium processing systems which contain RCRA metals ( $\mathrm{Hg}, \mathrm{Cd}, \mathrm{Ag}, \mathrm{Pb}$, etc.) or by replacement of Pd-Ag Permeators.

Annual Quantities:

\begin{tabular}{|c|r|r|}
\hline Waste Destination & Volume & Mass \\
\hline $\begin{array}{c}\text { Pd- } \mathrm{Ag} \text { Permeators to } \\
\text { Interim Storage/Off-site }\end{array}$ & $0.01 \mathrm{~m}^{3}$ & $23 \mathrm{~kg}$ \\
\hline
\end{tabular}

(a) Assume one $\mathrm{Pd}$-Ag permeator every 5 years.

(b) Assume each permeator is 12 in O. D . $\times 2$ feet long $\Rightarrow 1.6 \mathrm{ft}^{3}$.

(c) Assume, for shell container, 12" schedule 10 steel pipe (24.2 lb/ft) $=>48.4 \mathrm{lb}$.

(d) Assume, for tubes, $75 \%$ void, steel $(\mathrm{SpG}=8) \Rightarrow 200 \mathrm{lb}$.

(d) Divide unit weight $(\sim 250 \mathrm{lb})$ and volume by 5 to obtain annual generation rates.

Handling and Packaging: Following removal from process and glovebox, waste equipment is stored tó control offgassing tritium within a monitored ventilation system. Management will 
review offgassing rate and facility conditions to determine when to dispose of process equipment. Waste equipment pieces are wrapped in plastic bags. Following a period of offgassing, the plastic-wrapped equipment will be placed into pre-approved containers (meeting the macroencapsulation of debris RCRA ruling) for transport to the Mixed Waste Storage pads or off-site disposal.

Waste Minimization:

(a) Remove contaminants from the tritium extraction and processing lines to prolong permeator lifetime.

(b) Improve manufacturing methods or permeator design to eliminate current permeator brazing failures.

(c) Extend process equipment life by controlling process gas oxygen and water vapor limits.

(d) Extend process equipment life through reliability centered maintenance.

(e) Decontaminate equipment/recycle metal.

Treatment Options:

(a) Macroencapsulation prior to packaging for storage and/or disposal.

(b) Thermal desorption to remove as much tritium as practical.

(c) For hydride beds, use isotopic exchange following thermal desorption. Passivate hydride beds with compressed oxygen or air.

\section{Comments:}

(a) Failure of permeators has been attributed to manufacturer brazing problems or to contaminants in the current tritium processing lines. In a clean facility permeators last longer, as is demonstrated in the Replacement Tritium Facility (RTF). The hydrogen passing through the palladium will eventually cause embrittlement and swelling and will result in change-out even if current problems with brazing are resolved. Oxygen and water vapor can attack $\mathrm{Pd}-\mathrm{Ag}$ permeators, causing intergranular failure.

(b) Chromium in stainless steel, Inconel or zircaloy is assumed to pass the TCLP tests, due to the high corrosion resistance of these materials.

(c) TCLP testing of Pd-Ag permeators may allow this waste to be managed as low-level waste. 


\section{B4a. Silver Plated Waste Fittings}

Type: Mixed Low-level Waste

Description: Silver is used to coat stainless Cajon VCR vacuum fittings threads and gaskets in TSF. It is also used in many soldering and brazing compounds. Silver is used because it is very compatible with tritium. Silver is a hazardous material with RCRA code D011. During use the fittings will become contaminated with tritium.

\section{Average Hazardous Material Percentages \\ In Silver Fittings}

\begin{tabular}{|l|r|}
\hline Element & Average Percent \\
\hline $\mathrm{Ag}$ & $>3 \%$ \\
\hline
\end{tabular}

Generation: Existing tritium processing at SRS uses silver fittings as an anti-seize material.

Generated by preventative and corrective maintenance of the tritium processing systems containing $\mathrm{Ag}$ fittings or solder.

Annual Quantities:

\begin{tabular}{|c|r|r|}
\hline Waste Destination & Volume & Mass \\
\hline $\begin{array}{c}\text { Ag Fittings to Interim } \\
\text { Storage/Off-site }\end{array}$ & $0.01 \mathrm{~m}^{3}$ & $5 \mathrm{~kg}$ \\
\hline
\end{tabular}

(a) $5 \mathrm{~kg}$ per year replacement.

Handling and Packaging: Following removal from process and glovebox, waste fittings are stored to control offgassing tritium within a monitored ventilation system. Management will review offgassing rate and facility conditions to determine when to dispose of fittings. Waste fittings are wrapped in plastic bags. Following a period of off-gassing, the plastic-wrapped equipment will be placed into pre-approved containers (meeting the macroencapsulation of debris RCRA ruling) for transport to the Mixed Waste Storage pads or off-site disposal.

\section{Waste Minimization:}

(a) Remove contaminants from the tritium extraction and processing lines to fitting lifetime. 
(b) Improve manufacturing methods and/or maintenance procedures to eliminate soldering/brazing failures.

(c) Extend process equipment life by controlling process gas oxygen and water vapor limits.

(d) Extend process equipment life through reliability centered maintenance.

(e) Decontaminate equipment/recycle metal.

(f) Substitute Au for Ag in solders and brazing compounds.

\section{Treatment Options:}

(a) Macroencapsulation prior to packaging for storage and/or disposal.

(b) Thermal desorption to remove as much tritium as practical.

(c) React Ag to decrease solubility and ensure fittings pass TCLP.

\section{Comments:}

(a) Chromium in stainless steel, Inconel or zircaloy is assumed to pass the TCLP tests, due to the high corrosion resistance of these materials.

(b) TCLP testing of Ag fittings may allow this waste to be managed as low-level waste. 


\section{B5. Mixed and Hazardous Waste Oil/Solvent}

Type: Mixed Low-Level Waste, Hazardous Waste.

Description: Lubricating oil and solvents used for decontamination, cleaning, degreasing, spill clean-up and various maintenance activities may contain RCRA hazardous or listed components. Contamination with tritium and/or other radioactive components produces a mixed waste. Lubrication oil is used in vacuum pumps, blowers, robotic equipment, and vehicles operated in process buildings. Due to bearing wear or the tendency of oil to accumulate organic contaminants, waste oils have been found to contain the following RCRA codes: D005, D006, D008, D009, D018, F001, F003, F004, and F005. Past experience at SRS has shown pump oil associated with tritium facilities can have tritium activity levels ranging from background to 185 $\mathrm{Ci} /$. Residues of solutions used for decontamination, cleaning, or degreasing during equipment maintenance or repair may also be mixed waste. The solvents may be inherently hazardous and/or may become contaminated with radioactive or hazardous materials during the cleaning process. Oil and solvent will be contaminated with trace to significant amounts of the radionuclides listed in waste streams B3, B3a, B3b, B3c, B3d, B4, B9, B11, B12, B15, B16, B17, $\mathrm{B} 18$, and $\mathrm{B} 21$. The actual radionuclides and concentration will vary depending where in the APT facility the wastes are generated.

Generation: Routine analytical, process operation, maintenance, cleaning, degreasing, and decontamination activities.

Handling and Packaging: Segregate and store in a Satellite Accumulation Area per RCRA requirements (40CFR262.34(c)).

Annual Quantities: Minimal.

Waste Minimization:

(a) Product substitution, to eliminate RCRA hazardous solvents.

(b) Change to mechanical/physical stripping/cleaning devices to avoid solvent use.

(c) Use of dry pumps (e.g. Normetex, Met-Bell) for tritium pumping.

(d) Use of oil-free blowers for discharges to stacks.

(e) Use water-cooled and lubricated cooling system pumps.

\section{Treatment Options:}

(a) Incineration at CIF, followed by stabilization or vitrification of ash. 
(b) Stabilization. Considering that the annual volume estimate is small, just stabilization may be more practical.

Hazardous Waste:

(a) Energy recovery at the SRS power house, if halogen compounds are within allowable limits.

(b) Ship to a DOE-approved commercial treatment and disposal facility.

\section{Comments:}

(a) Used oil is regulated as a hazardous waste in the State of California.

(b) Current environmental regulations make it advantageous to avoid the generation of mixed waste. Use of nonhazardous oils for equipment and nonhazardous cleaning agents is highly advisable. For example, a new, nonhazardous and environmentally safe solvent for cleaning metal surfaces is available through Organitec, a Tennessee-based company. Common detergent is very effective in some cases.

(c) While thermal desorption of volatile organics may convert a mixed waste to a low-level waste, if the off-gases are adsorbed on activated carbon, the spent carbon bed becomes a secondary waste stream.

(d) Double containment bellow-sealed pumps and dry, all-metal scroll pumps are viable candidates. However, these pumps are sensitive to particulate, chemical, and mercury attack, so the process lines must be kept very clean.

(e) With the exception of compressors, 233-H tritium process pumps do not use mercury or organic lubricants. 


\section{B6. Mixed Waste Solvent Rags}

Type: Mixed Low-level Waste.

Description: Rags or paper products (such as Kim-Wipes) that have been impregnated with solutions used for decontamination, cleaning, degreasing, spill clean-up and various maintenance activities. The solutions may contain hazardous components such as Freon or methanol and/or may also become contaminated with radioactive or hazardous components wiped from the object being cleaned. Rags will be contaminated with trace to significant amounts of the radionuclides listed in waste streams B3, B3a, B3b, B3c, B3d, B4, B9, B11, B12, B15, B16, B17, B18, and $\mathrm{B} 21$. The actual radionuclides and concentration will vary depending where in the APT facility the rags are used.

Generation: Routine maintenance, cleaning, degreasing, and decontamination activities.

Handling and Packaging: Handled and packaged similarly to job control waste. Waste items are placed in plastic bags and 21 " $\times 21$ "x 21 " cardboard boxes. The outside of the plastic bags are smeared for contamination and sniffed for detectable tritium offgassing of $4 \mathrm{E}-5 \mu \mathrm{Ci} / \mathrm{cc}$.

Annual Quantities: Minimal. Included in Mixed Job Control Waste (B2). APT is not expected to use any RCRA regulated solvents.

Waste Minimization:

(a) Product substitution, to eliminate RCRA hazardous solvents (e.g., Freon, methanol).

(b) Change to mechanical/physical stripping/cleaning devices to avoid solvent use.

\section{Treatment Options:}

(a) Thermal desorption followed by compaction for storage and/or disposal.

(b) Incineration at CIF, followed by stabilization or vitrification of ash.

\section{Comments:}

(a) Current environmental regulations make it advantageous to avoid the generation of mixed waste. Use of nonhazardous cleaning agents is advisable when the solvent rags will come in contact with radioactive materials. Commercially available rags impregnated with a decontamination solution (brand name Maslin Wipes) have been tested by Sandia National Laboratories - New Mexico for hazardous components and have been found to be nonhazardous. 
(b) While thermal desorption of volatile organics may convert a mixed waste to a low-level waste, if the off-gas is absorbed on activated carbon, the spent carbon bed becomes a secondary waste stream.

(c) APT uses no hazardous solvents. 


\section{B7. Analytical Laboratory/Rad Con Chemicals}

Type: Hazardous, or Mixed Low-level Waste.

Description: Used, excess, or out-of-date chemicals used by Analytical Laboratories and Rad Con in Tritium. The chemicals identified in this waste stream are considered hazardous and may be solids, liquids, or gels. Gas standards and other pressurized gases are excluded. A variety of hazardous waste codes are possible. Chemicals can be contaminated with trace to significant amounts of the radionuclides listed in waste streams B3, B3a, B3b, B3c, B3d, B4, B9, B11, B12, $\mathrm{B} 15, \mathrm{~B} 16, \mathrm{~B} 17, \mathrm{~B} 18$, and $\mathrm{B} 21$. The actual radionuclides and concentration will vary depending upon the analysis performed.

Generation: Routine analytical chemistry and radiological control procedures needed to support operations of the APT. Used chemicals are hazardous and may become a mixed waste, if used in a radioactive-contaminated environment. These chemicals are used by Analytical Lab and Rad Con and reported in the draft 1996 Tier II Hazardous Chemical Inventory Report (source: R. A. Rhodes, Tritium Chemical Coordinator).

\section{Annual Quantities:}

Since consumption of these chemicals will result in discharges to the APT Liquid Radwaste System, building HVAC, job control waste, tritiated oil, etc., the projected quantities below are considered to be reflected and included in the other waste streams.

\begin{tabular}{|r|r|r|}
\hline Waste Destination & Volume & Mass \\
\hline CIF\& E-Area, & $0.8 \mathrm{~m}^{3}$ & $773 \mathrm{~kg}$ \\
\hline Off-Site & $0.5 \mathrm{~m}^{3}$ & $483 \mathrm{~kg}$ \\
\hline Total & $1.3 \mathrm{~m}^{3}$ & $1,256 \mathrm{~kg}$ \\
\hline
\end{tabular}

(a) Annual usage estimated based on $4 \mathrm{x}$ average inventory. See Table $\mathrm{B} 2$ for distribution.

(b) Assumed an average $\mathrm{SpG}=1$, or $62.3 \mathrm{lb} / \mathrm{ft}^{3}$.

(c) $50 \%$ to $\mathrm{CIF}$

(d) $50 \%$ mixed or hazardous waste

\section{Waste Minimization:}

(a) Use micro-analytical equipment to minimize chemical usage.

(b) Buy only required amounts to minimize disposal of expired excess chemicals.

Treatment Options:

Will be a function of the type of chemical; e.g., solid, liquid, acid, base, etc. 
APT

Pollution Prevention Design Assessment
WSRC-TR-97-0260

Rev 0

September 18, 1997

Comments: None. 
Table B2

\section{Tritium Analytical Laboratory/Rad Con \\ Tier II Hazardous Chemical Inventory \\ For Reference Use}

(10/96)

\begin{tabular}{|c|c|c|c|c|}
\hline Chemical & Manufacturer & $\begin{array}{c}\text { Average } \\
\text { Inventory } \\
\text { lb } \\
\end{array}$ & $\begin{array}{c}\text { Maximum } \\
\text { Inventory } \\
\text { lb }\end{array}$ & $\begin{array}{c}\text { Estimated } \\
\text { Usage* }^{*} \\
\text { Ib/yr }\end{array}$ \\
\hline ABC Dry Chemical & Amerex & 10 & 10 & 40.0 \\
\hline Aero Clearview Glass Cleaner & ABC Compounding & 2.4 & 2.4 & 9.6 \\
\hline Aero Ammoniated Glass Cleaner & ABC Compounding & 0.7 & 0.75 & 3.0 \\
\hline Aero Lemonair Air Freshner & ABC Compounding & 0.65 & 0.7 & 2.6 \\
\hline Alconox & Alconox & 2 & 4 & 8.0 \\
\hline $\begin{array}{l}\text { All Pro AP210 Lemon Yellow } \\
\text { Spray Paint }\end{array}$ & Major Paint & 0.75 & 0.75 & 3.0 \\
\hline $\begin{array}{l}\text { All Pro AP230 Orange Spray } \\
\text { Paint }\end{array}$ & Major Paint & 0.75 & 0.75 & 3.0 \\
\hline Apiezon Products & James E. Biddle & 4.4 & 4.4 & 17.6 \\
\hline Ax-It-Plus Stripper & Betco & 3.0 & 3.0 & 12.0 \\
\hline Brillo Soap Pads & Purex Industrial & 1 & 1 & 4.0 \\
\hline Comet Cleanser & Proctor \& Gamble & 2 & 2 & 8.0 \\
\hline CRC 3-36 Aerosol & CRC Industries & 1 & 1 & 4.0 \\
\hline $\begin{array}{l}\text { Dow Corning Multi-purpose } \\
\text { Sealant }\end{array}$ & Dow Corning & 1 & 1 & $\overline{4.0}$ \\
\hline Dow Corning High Vacuum Grease & Dow Corning & 1.6 & 1.6 & 6.4 \\
\hline Duo-seal Vacuum Pump Oil & $\begin{array}{l}\text { Weich Vacuum } \\
\text { Technology }\end{array}$ & 2.0 & 2.0 & 8.0 \\
\hline Easy-off Oven Cleaner & Reckitt \& Coleman & 1.2 & 1.2 & 4.8 \\
\hline Enviro-Tech Precision Dusting & Tech Spray & 7.5 & 7.5 & 30.0 \\
\hline Ethanol USP-190 proof & $\begin{array}{l}\text { AAPER Alcohol \& } \\
\text { Chemical }\end{array}$ & 4.8 & 5.0 & 19.2 \\
\hline Ethylene Glycol & Mallinckrodt & 0.1 & 0.1 & 0.4 \\
\hline Inlet 19 Vacuum Pump Oil & $\begin{array}{l}\text { Inland Vacuum } \\
\text { Industries }\end{array}$ & 20.0 & .20 .2 & 80.0 \\
\hline Isoclean Concentration & Isolab & 2.2 & 2.2 & 8.8 \\
\hline Joy Liquid Dishwashing Detergent & Proctor \& Gamble & 1 & 1 & 4.0 \\
\hline Kimwipes lens cleaning solution & Kimberly-Clark & 1.75 & 1.75 & 7.0 \\
\hline Leak-Tec $277 \mathrm{C}$ & $\begin{array}{l}\text { American gas \& } \\
\text { Chemical } \\
\end{array}$ & 1.3 & 1.35 & 5.2 \\
\hline Mechanical Pump Oil 15 & $\begin{array}{l}\text { Edwards High } \\
\text { Vacuum }\end{array}$ & 7.3 & 7.4 & 29.2 \\
\hline
\end{tabular}

*Estimated annual usage based on $4 x$ average inventory. 


\section{Table B2 (Cont'd)}

\section{Tritium Analytical Laboratory/Rad Con Tier II Hazardous Chemical Inventory \\ For Reference Use}

$(10 / 96)$

\begin{tabular}{|l|l|r|r|r|}
\hline \multicolumn{1}{|c|}{ Chemical } & Manufacturer & \multicolumn{1}{c|}{$\begin{array}{c}\text { Average } \\
\text { Inventory } \\
\text { lb }\end{array}$} & $\begin{array}{c}\text { Maximum } \\
\text { Inventory } \\
\text { lb }\end{array}$ & \multicolumn{1}{c|}{$\begin{array}{c}\text { Estimated } \\
\text { Usage* } \\
\text { lb/yr }\end{array}$} \\
\hline Mercury Spill Clean-up Kit & JT Baker & 2.5 & 2.5 & 10.0 \\
\hline $\begin{array}{l}\text { Met-L-X Dry Powder Extinguisher } \\
\text { Agent }\end{array}$ & $\begin{array}{l}\text { Ansul Fire } \\
\text { Protection }\end{array}$ & 53.7 & 53.7 & 214.8 \\
\hline Mighty X Wax Stripper & AMREP & 1.4 & 1.5 & 5.6 \\
\hline NoKoRude Soldering Paste & M.W. Dunton & 1.0 & 1.0 & 4.0 \\
\hline Opti-Fluor & $\begin{array}{l}\text { Packard } \\
\text { Instruments }\end{array}$ & 529.4 & 532.4 & 2117.6 \\
\hline RTV128 Silicone Rubber Sealant & General Electric & 0.2 & 0.2 & 0.8 \\
\hline $\begin{array}{l}\text { Rustmaster Spray Enamel OSHA } \\
\text { Orange }\end{array}$ & Glidden & 0.7 & 0.75 & 2.8 \\
\hline Santovac 5 Vacuum Pump Fluid & Monsanto & 0.25 & 0.3 & 1.0 \\
\hline Septisol Solution & Calgon Vestal Lab & 2.0 & 2.1 & 8.0 \\
\hline Sodium Hydroxide Solid & EM Science & 1.1 & 1.1 & 4.4 \\
\hline Superacrylic Spray Enamel & Sherwin Williams & 0.5 & 0.5 & 2.0 \\
\hline Trichlorofluoroethane & Allied Signal & 1.0 & 1.0 & 4.0 \\
\hline WBBM S5 Shredder Oil & Whitaker Brothers & 16.3 & 17.5 & 65.2 \\
\hline
\end{tabular}

*Estimated annual usage based on $4 \mathrm{x}$ average inventory. 


\section{B8. Teledyne Oxygen Sensor Micro-Fuel Cells}

Type: Mixed Low-level Waste, Hazardous Waste.

Description: Micro-fuel cells used in the Teledyne oxygen sensors are sealed in a cell with lead (D008). The sensors are used in both clean and radioactively-contaminated environments.

\section{Average Hazardous Material Percentages}

Teledyne Oxygen Sensors

\begin{tabular}{|l|r|}
\hline Element & Average Percent \\
\hline $\mathrm{Cr}$ & $\mathrm{TBD}$ \\
\hline $\mathrm{Cd}$ & $\mathrm{TBD}$ \\
\hline $\mathrm{Pb}$ & $\mathrm{TBD}$ \\
\hline
\end{tabular}

Generation: Spent fuel cells from Teledyne oxygen sensors used in radioactive environments become a mixed waste. Defective unused fuel cells or spent fuel cells from Teledyne sensors in clean areas will be a hazardous waste.

Handling and Packaging: Store in a Satellite Area per RCRA requirements (40CFR262.34 (c)).

Annual Quantities:

\begin{tabular}{|c|r|r|}
\hline Waste Destination & Volume & Mass \\
\hline Hazardous to Off-site & $0.004 \mathrm{~m}^{3}$ & $4.5 \mathrm{~kg}$ \\
\hline Mixed to Off-site/Storage & $0.004 \mathrm{~m}^{3}$ & $6.8 \mathrm{~kg}$ \\
\hline
\end{tabular}

(a) Assume 10 spent cells per year in clean areas and 10 spent cells per year in tritiumcontaminated area.

(b) Assume clean spent cells shipped to off-site vendor in 3.8 liter container.

(c) Assume 3.8 liter containerized waste weighs $11 \mathrm{~kg}$.

(d) Assume mixed cells macroencapsulated in 3.8 liter container for off-site vendor or storage.

(e) Assume macroencapsulated waste form results in $50 \%$ weight increase.

Waste Minimization:

Product substitution to eliminate RCRA hazardous lead.

Treatment Options: 
Hazardous Waste: Ship to a DOE-approved commercial treatment and disposal facility. Mixed Waste: Macroencapsulation followed by disposal in a RCRA Subtitle C facility.

\section{Comments:}

Current environmental regulations make it advantageous to avoid the generation of mixed waste. Use of a nonhazardous, non-lead substitute product appears to be the most practical solution. 


\section{B9. Mixed Waste Lead}

Type: Mixed Low-level Waste.

Description: Radioactive Lead Solids (D008C). This waste will be in modules of various sizes used as neutron sources in the Target/Blanket cavity vessel. The modules will have various configurations depending on the region of origination in the cavity vessel. The modules will be on average $60 \%$ lead, $20 \%$ aluminum, and $20 \%$ void space. They will have been exposed to the proton beam and will be activated with numerous spallation products.

\section{Average Hazardous Material Content \\ In Lead Modules}

\begin{tabular}{|l|r|}
\hline Element & Average Content \\
\hline $\mathrm{Cr}$ & $100 \mathrm{ppm}$ \\
\hline $\mathrm{As}$ & $5 \mathrm{ppm}$ \\
\hline $\mathrm{Se}$ & $20 \mathrm{ppm}$ \\
\hline $\mathrm{Ag}$ & $5 \mathrm{ppm}$ \\
\hline $\mathrm{Cd}$ & $40 \mathrm{ppm}$ \\
\hline $\mathrm{Ba}$ & $9 \mathrm{ppm}$ \\
\hline $\mathrm{Hg}$ & $700 \mathrm{ppm}$ \\
\hline $\mathrm{Pb}$ & $60 \%$ \\
\hline
\end{tabular}

Lead Module Maximum Average Nuclides in $\mathrm{Ci} / \mathrm{CC}$ (time period is from beam shutdown)

\begin{tabular}{|c|c|c|c|}
\hline Nuclide & Halflife,s & 2 years & 10 years \\
\hline H 3 & $3.89 E+08$ & 1.47E-01 & $9.39 E-02$ \\
\hline$\overline{8 e 7}$ & $4.61 E+06$ & $9.44 E-07$ & $2.97 \mathrm{E}-23$ \\
\hline$B e 10$ & $5.05 E+13$ & $9.69 E-09$ & $9.69 \mathrm{E}-09$ \\
\hline$C_{14}$ & $1.81 E+11$ & $1.42 \mathrm{E}-05$ & $1.42 E-05$ \\
\hline $\mathrm{Na} 22$ & $8.21 E+07$ & $9.37 E-03$ & $1.11 \mathrm{E}-03$ \\
\hline A126 & $2.27 E+13$ & $7.44 E-07$ & $7.44 \mathrm{E}-07$ \\
\hline$\overline{S i 32}$ & $5.43 E+09$ & $8.39 E-11$ & $8.13 E-11$ \\
\hline P 32 & $1.23 E+06$ & $8.40 E-11$ & $8.13 E-11$ \\
\hline P 33 & $2.19 E+06$ & $1.74 \mathrm{E}-12$ & $4.07 \mathrm{E}-47$ \\
\hline 535 & $7.56 E+06$ & $2.10 E-08$ & $1.86 \mathrm{E}-18$ \\
\hline$\overline{\mathrm{Cl} 36}$ & $9.50 \mathrm{E}+12$ & $1.93 E-08$ & $1.93 \mathrm{E}-08$ \\
\hline Ar 37 & $3.03 E+06$ & 5.37E-09 & $0.00 E+00$ \\
\hline Ar 39 & $8.49 E+09$ & $2.13 E-06$ & $2.09 E-06$ \\
\hline $\operatorname{Ar} 42$ & $1.04 E+09$ & $2.56 E-05$ & 2.17E-05 \\
\hline K40 & $4.03 E+16$ & $4.73 E-11$ & 11 \\
\hline
\end{tabular}




\begin{tabular}{|l|r|r|r|}
\hline K 42 & $4.45 E+04$ & $2.56 E-05$ & $2.17 E-05$ \\
\hline
\end{tabular}




\begin{tabular}{|c|c|c|c|}
\hline Nuclide & Halflife,s & 2 years & 10 years \\
\hline $\mathrm{Ca} 41$ & $3.25 E+12$ & 4.98E 07 & $4.98 E-07$ \\
\hline $\mathrm{Ca} 45$ & $1.42 E+07$ & $7.38 E-05$ & $3.15 \mathrm{E}-1 \mathrm{C}$ \\
\hline$S c 44$ & $1.41 \mathrm{E}+04$ & $2.00 E-18$ & $1.78 \mathrm{E}-18$ \\
\hline Sc 46 & $7.24 E+\infty 6$ & $1.36 \mathrm{E}-06$ & $4.33 E-17$ \\
\hline$\sqrt{49}$ & $2.92 E+07$ & $1.75 E-04$ & 4.37E-07 \\
\hline$\sqrt{50}$ & $4.70 E+24$ & $8.78 E-21$ & $8.78 E-21$ \\
\hline Cr 51 & $2.39 E+06$ & $4.28 \mathrm{E}-11$ & $0.00 E+00$ \\
\hline $\operatorname{Mn} 53$ & $1.18 E+14$ & $5.61 E-10$ & 5.61E-10 \\
\hline $\operatorname{Mn} 54$ & $2.70 E+07$ & $2.12 E-05$ & 3.23E-08 \\
\hline $\mathrm{Fe} 55$ & $8.62 E+07$ & $6.92 E-05$ & $9.07 E-06$ \\
\hline $\mathrm{Fe} 59$ & $3.84 E+06$ & $1.47 \mathrm{E}-08$ & $2.51 \mathrm{E}-28$ \\
\hline $\mathrm{Fe} 60$ & $4.73 E+13$ & $1.21 \mathrm{E}-09$ & $1.21 \mathrm{E}-09$ \\
\hline $\operatorname{Cos} 56$ & $6.80 E+06$ & $8.04 E-07$ & $5.46 \mathrm{E}-18$ \\
\hline $\operatorname{Co5} 5$ & $2.35 E+07$ & $3.16 E-05$ & $1.83 E-08$ \\
\hline $\cos 58$ & $6.13 E+06$ & $2.83 E-07$ & $1.12 \mathrm{E}-19$ \\
\hline Co 60 & $1.66 \mathrm{E}+08$ & $1.62 E-04$ & $5.66 E-05$ \\
\hline $\operatorname{Co6} 60^{*}$ & $6.28 E+02$ & $1.21 \mathrm{E}-0 \mathrm{~S}$ & 1.21E-09 \\
\hline$\overline{N i 59}$ & $2.37 E+12$ & $3.13 E-11$ & $3.13 E-11$ \\
\hline Ni 63 & $3.16 E+09$ & $5.20 E-05$ & $4.92 E-05$ \\
\hline $2 \pi 65$ & $2.11 E+07$ & $7.83 E-05$ & $1.94 E-08$ \\
\hline Ga 68 & $4.06 E+03$ & $6.32 E-05$ & $3.57 \mathrm{E}-08$ \\
\hline $\mathrm{Ge} 68$ & $2.34 E+07$ & $6.32 E-05$ & $3.57 E-08$ \\
\hline As 73 & $6.94 E+06$ & $4.51 E-06$ & $5.01 E-17$ \\
\hline As 74 & $1.54 \mathrm{E}+06$ & $7.88 \mathrm{E}-16$ & $0.00 E+00$ \\
\hline 5 & $1.03 E+07$ & $3.05 E-05$ & $1.38 \mathrm{E}-12$ \\
\hline$\overline{\text { Se } 79}$ & $1.04 E+12$ & $1.49 E-07$ & 1.49E-07 \\
\hline $\mathrm{kr} 81$ & $6.72 E+12$ & 2.17E-08 & 2.17E-08 \\
\hline Kr85 & $3.38 E+08$ & $1.83 E-04$ & 1.09E-04 \\
\hline $\mathrm{Rb} 82$ & $7.64 \mathrm{E}+01$ & $2.35 E-18$ & $0.00 E+00$ \\
\hline $\mathrm{Rb} 83$ & $7.45 E+06$ & $9.27 \mathrm{E}-0.9$ & $5.80 E-16$ \\
\hline$\overline{R b} 84$ & $2.84 E+06$ & 5.11E-19 & $8.88 E-37$ \\
\hline$\overline{R b} 86$ & $1.61 E+06$ & 1.31E-15 & $0.00 E+00$ \\
\hline$R \mathrm{Rb} 87$ & $1.51 E+18$ & $9.61 E-14$ & $9.61 \mathrm{E}-14$ \\
\hline Sr 82 & $2.21 E+0 \sigma$ & $2.35 E-18$ & $0.00 E+00$ \\
\hline $5 r 85$ & $5.60 E+06$ & 9.27E-07 & $2.52 E-20$ \\
\hline$\overline{s r} 89$ & $4.37 E+06$ & 1.71E-07 & $6.81 E-25$ \\
\hline Sr90 & $8.88 E+08$ & $1.89 E-04$ & $1.56 \mathrm{E}-04$ \\
\hline Y 88 & $9.21 \mathrm{E}+0 \mathrm{G}$ & 4.78E-05 & $3.25 E-13$ \\
\hline $\bar{Y} 89^{*}$ & $1.61 E+01$ & 1.59E-11 & $0.00 E+00$ \\
\hline Y90 & $2.31 E+05$ & $1.90 E-04$ & $1.56 \mathrm{E}-04$ \\
\hline Y91 & $5.06 E+06$ & 4.19E-07 & $3.88 E-22$ \\
\hline$\overline{288}$ & $7.21 E+06$ & $2.86 \mathrm{E}-06$ & $8.13 E-17$ \\
\hline Zr93 & $4.83 E+13$ & $4.92 \mathrm{E}-09$ & $4.92 E-09$ \\
\hline
\end{tabular}




\begin{tabular}{|c|c|c|c|}
\hline Nuclide & Halflife,s & 2 years & 10 years \\
\hline Zr95 & $5.53 E+\infty 6$ & $1.19 E-06$ & $2.16 \mathrm{E}-20$ \\
\hline Nb 91 & $2.15 E+10$ & $7.24 \mathrm{E}-06$ & $7.18 E-06$ \\
\hline $\mathrm{Nb} 91^{*}$ & $5.36 E+06$ & $1.11 E-09$ & $7.21 \mathrm{E}-24$ \\
\hline $\mathrm{Nb} 92$ & $1.10 E+15$ & $7.58 E-11$ & $7.58 \mathrm{E}-11$ \\
\hline $\mathrm{Nb} 93^{*}$ & $5.09 E+08$ & $1.77 \mathrm{E}-06$ & $1.56 \mathrm{E}-06$ \\
\hline $\mathrm{Nb} 94$ & $6.41 E+11$ & $1.87 \mathrm{E}-07$ & 1.87E-07 \\
\hline $\mathrm{Nb} 95$ & $3.02 E+06$ & $2.62 E-06$ & $4.71 E-20$ \\
\hline $\mathrm{Nb} 95^{*}$ & $3.12 E+05$ & $1.40 E-08$ & $2.54 \mathrm{E}-22$ \\
\hline Mo 93 & $1.10 E+11$ & $1.28 \mathrm{E}-06$ & $128 E-06$ \\
\hline Tc 95 & $7.20 E+04$ & $2.58 \mathrm{E}-13$ & $0.00 E+\infty 0$ \\
\hline Tc 95" & $5.27 E+06$ & $6.37 E-12$ & $2.41 E-26$ \\
\hline Tc 97 & $8.20 E+13$ & $1.52 E-09$ & $1.52 \mathrm{E}-09$ \\
\hline $\operatorname{Tc} 97^{*}$ & $7.82 \mathrm{E}+06$ & $1.46 E-08$ & $2.78 E-18$ \\
\hline Tc 98 & $1.33 E+14$ & $5.70 E-10$ & $5.70 E-10$ \\
\hline Tс 99 & $6.66 E+12$ & $5.27 E-08$ & 5.27E-08 \\
\hline Ru103 & $3.39 E+06$ & $6.04 E-09$ & $2.38 \mathrm{E}-31$ \\
\hline Ru106 & $3.21 \mathrm{E}+07$ & $1.46 E-04$ & $6.28 E-07$ \\
\hline Rh 99 & $1.39 E+06$ & $1.14 \mathrm{E}-17$ & $0.00 E+00$ \\
\hline Rh101 & $1.04 E+08$ & $9.63 \mathrm{E}-04$ & $1.79 \mathrm{E}-04$ \\
\hline Rh102 & $9.15 E+07$ & $2.18 \mathrm{E}-04$ & $3.23 E-05$ \\
\hline Rh102* & $1.79 E+07$ & $1.55 \mathrm{E}-05$ & $8.71 \mathrm{E}-10$ \\
\hline Rh103* & $3.37 \mathrm{E}+03$ & $6.03 E-09$ & $0.00 E+00$ \\
\hline Rh106 & $2.98 E+01$ & 1.46E-04 & $6.28 E-07$ \\
\hline Pd103 & $1.47 \mathrm{E}+06$ & $1.80 \mathrm{E}-16$ & $0.00 E+00$ \\
\hline Pd107 & $2.05 E+14$ & $1.26 \mathrm{E}-09$ & $1.26 E-09$ \\
\hline Ag105 & $3.57 \mathrm{E}+0 \mathrm{\sigma}$ & 8.13E-09 & $4.02 E-30$ \\
\hline Ag108 & $1.42 E+02$ & $1.86 \mathrm{E}-09$ & $1.78 E-09$ \\
\hline $\operatorname{Ag} 108^{*}$ & $4.01 E+09$ & $2.14 E-08$ & $2.05 E-08$ \\
\hline $\operatorname{Ag} 109^{*}$ & $3.96 E+01$ & $3.12 E-04$ & $3.91 E-06$ \\
\hline $\mathrm{Ag} 110$ & $2.46 \mathrm{E}+01$ & 2.98E-07 & 8.97E-11 \\
\hline $\operatorname{Ag} 110^{\circ}$ & $2.16 E+07$ & 2.19E-05 & 6.59E-09 \\
\hline $\operatorname{cod} 109$ & $4.00 E+07$ & $3.12 \mathrm{E}-04$ & $3.91 E-06$ \\
\hline $\operatorname{cod113^{*}}$ & $4.45 E+08$ & $1.24 \mathrm{E}-0 \mathrm{7}$ & $8.34 E-08$ \\
\hline Cd115" & $3.85 \mathrm{E}+06$ & $7.20 E-10$ & $1.36 E-29$ \\
\hline $\ln 113^{*}$ & $5.97 E+03$ & 6.07E-06 & $1.38 \mathrm{E}-13$ \\
\hline $\ln 114$ & $7.19 E+01$ & $1.49 E-08$ & $0.00 E+00$ \\
\hline $\ln 114^{*}$ & $4.28 \mathrm{E}+06$ & $1.55 E-08$ & $2.66 E-26$ \\
\hline $\ln 115^{*}$ & $1.62 \mathrm{E}+04$ & $7.95 E-14$ & $0.00 E+00$ \\
\hline Sn113 & $9.94 E+06$ & 6.07E-06 & $1.38 \mathrm{E}-13$ \\
\hline Sn119* & $2.53 E+07$ & $3.54 E-06$ & $3.52 \mathrm{E}-09$ \\
\hline Sn121 & $9.74 E+04$ & $1.33 E-06$ & $1.20 \mathrm{E}-06$ \\
\hline Sn121* & $1.74 E+09$ & 1.71E-06 & $1.54 E-06$ \\
\hline
\end{tabular}




\begin{tabular}{|l|l|l|l|}
\hline Sn123 & $1.12 E+07$ & $2.67 E-07$ & $4.15 E-14$ \\
\hline
\end{tabular}




\begin{tabular}{|c|c|c|c|}
\hline Nuclide & Halfifife,s & 2 years & 10 years \\
\hline Sn125 & $8.33 E+05$ & $4.56 \mathrm{E}-28$ & $0.00 \mathrm{E}+00$ \\
\hline Sn126 & $3.16 E+12$ & $1.41 E-13$ & $1.41 \mathrm{E}-13$ \\
\hline S6124 & $5.20 E+06$ & 2.42E-07 & $5.92 E-22$ \\
\hline S6125 & $8.62 \mathrm{E}+07$ & $1.40 \mathrm{E}-04$ & $1.83 E-05$ \\
\hline Sb126 & $1.07 E+06$ & $1.98 E-14$ & $1.98 E-14$ \\
\hline Sb126" & $1.14 \mathrm{E}+03$ & $1.41 \mathrm{E}-13$ & $1.41 E-13$ \\
\hline Sb12 & $1.10 E+01$ & $9.47 E-14$ & $9.47 E-14$ \\
\hline Te118 & $5.18 E+05$ & $2.35 E-49$ & $0.00 E+00$ \\
\hline Te121 & $1.45 E+06$ & $3.59 E-07$ & $6.98 E-13$ \\
\hline Te121" & $1.33 E+07$ & $3.61 \mathrm{E}-07$ & $7.02 E-13$ \\
\hline Te123 & $3.91 E+20$ & $6.21 \mathrm{E}-17$ & $6.21 E-17$ \\
\hline Te123* & $1.03 E+07$ & $5.10 E-07$ & $2.29 \mathrm{E}-14$ \\
\hline Te125* & $5.01 E+06$ & $3.41 \mathrm{E}-05$ & $4.47 E-06$ \\
\hline Te127 & $3.37 \mathrm{E}+04$ & $1.22 E-06$ & $1.04 \mathrm{E}-14$ \\
\hline Te127* & $9.42 E+06$ & $1.24 \mathrm{E}-06$ & $1.06 E-14$ \\
\hline Te129 & $4.18 E+03$ & $8.70 E-12$ & $0.00 E+00$ \\
\hline Te129* & $2.90 E+06$ & $1.36 \mathrm{E}-11$ & $8.98 E-38$ \\
\hline$\longdiv { 1 2 5 }$ & $5.20 E+06$ & 3.30E-07 & $7.81 E-22$ \\
\hline 126 & $1.12 \mathrm{E}+06$ & 8.74E-21 & 2.41E-88 \\
\hline 1129 & $4.95 E+14$ & 5.52E-11 & $5.52 E-11$ \\
\hline 1131 & $6.95 E+05$ & $3.03 E-34$ & $0.00 \mathrm{E}+00$ \\
\hline Xe127 & $3.15 E+06$ & $1.50 E-09$ & $1.02 E-33$ \\
\hline Cs134 & $6.51 \mathrm{E}+0 \overline{7}$ & $1.70 E-04$ & $1.15 E-05$ \\
\hline Cs135 & $7.26 \mathrm{E}+13$ & $4.58 E-10$ & $4.58 \mathrm{E}-10$ \\
\hline Cs137 & $9.47 E+08$ & 2.05E-08 & 1.71E-08 \\
\hline $\mathrm{Ba133}$ & $3.32 E+08$ & 229E-04 & $1.35 E-04$ \\
\hline $\mathrm{Ba137}^{*}$ & $1.53 E+02$ & $1.94 E-08$ & $1.61 E-08$ \\
\hline La137 & $1.89 \mathrm{E}+12$ & 2.11E-08 & $2.11 E-08$ \\
\hline La138 & $3.31 E+18$ & 1.15E-14 & $1.15 E-14$ \\
\hline Ce139 & $1.19 E+07$ & $2.48 \mathrm{E}-05$ & 1.01E-11 \\
\hline Ce141 & $2.81 E+06$ & $9.02 E-11$ & $7.78 E-38$ \\
\hline Ce144 & $2.46 E+07$ & $9.06 \mathrm{E}-09$ & $7.40 \mathrm{E}-12$ \\
\hline Pri44 & $1.04 E+03$ & $9.06 E-09$ & $7.40 E-12$ \\
\hline Pr144" & $4.32 E+02$ & $1.27 E-10$ & $1.04 E-13$ \\
\hline Nd144 & $6.60 E+22$ & $1.08 E-18$ & $1.09 E-18$ \\
\hline Prn143 & $2.29 E+07$ & $3.56 E-04$ & 1.71E-07 \\
\hline Pm144 & $3.14 E+07$ & 1.41E-0S & $5.35 E-08$ \\
\hline Pm145 & $5.59 E+08$ & 7.96E-05 & 6.24E-05 \\
\hline Pm146 & $1.75 E+08$ & 5.25E-06 & $1.92 \mathrm{E}-06$ \\
\hline Pm147 & $8.28 E+07$ & $7.98 \mathrm{E}-05$ & 9.63E-06 \\
\hline Pm148 & $4.64 \mathrm{E}+05$ & $8.13 \mathrm{E}-12$ & $0.00 E+00$ \\
\hline Pm148* & $3.57 \mathrm{E}+0 \mathrm{~d}$ & $1.54 \mathrm{E}-10$ & $7.66 \mathrm{E}-32$ \\
\hline Sm145 & $2.94 E+07$ & $1.05 E-04$ & $2.72 E-07$ \\
\hline
\end{tabular}


APT

WSRC-TR-97-0260

Pollution Prevention Design Assessment

Rev 0

September 18, 1997

\begin{tabular}{|l|l|l|r|}
\hline Sm146 & $3.25 E+15$ & $5.03 E-11$ & $5.03 E-11$ \\
\hline$S m 147$ & $3.35 E+18$ & $2.57 E-14$ & $2.75 E-14$ \\
\hline
\end{tabular}




\begin{tabular}{|c|c|c|c|}
\hline Nuclide & Halflife,s & 2 years & 10 years \\
\hline Sm151 & $2.84 E+09$ & 8.41E-06 & 7.90E-OO \\
\hline Eu145 & $5.12 E+05$ & $0.00 E+00$ & $0.00 E+00$ \\
\hline Eu146 & $3.97 \mathrm{E}+05$ & 4.63E-08 & $0.00 E+00$ \\
\hline Eu147 & $2.07 E+06$ & $1.44 \mathrm{E}-12$ & $0.00 E+\infty 0$ \\
\hline Eu148 & $4.71 E+06$ & 5.10E-09 & $3.73 E-25$ \\
\hline Eu149 & $8.04 E+06$ & $1.30 E-05$ & $4.60 E-15$ \\
\hline Eu150 & $1.13 E+09$ & 1.41E-05 & $1.21 \mathrm{E}-05$ \\
\hline Eu152 & $4.21 E+08$ & 1.62E-05 & $1.07 \mathrm{E}-05$ \\
\hline Eu154 & $2.71 E+08$ & $7.79 E-05$ & $4.09 E-05$ \\
\hline Eu155 & $1.48 E+08$ & $2.00 E-05$ & $6.11 E-06$ \\
\hline Gd146 & $4.17 E+06$ & 4.19E-08 & $2.52 E-26$ \\
\hline Go148 & $2.35 E+09$ & $6.94 E-05$ & $6.44 E-05$ \\
\hline Gd149 & $8.10 E+05$ & $1.25 \mathrm{E}-26$ & $0.00 E+00$ \\
\hline Gd150 & $5.65 E+13$ & 2.42E-09 & 2.42E-09 \\
\hline Gd151 & 1.07E+07 & $5.06 \mathrm{E}-05$ & $4.06 \mathrm{E}-12$ \\
\hline Gd152 & $3.41 E+21$ & $8.35 \mathrm{E}-17$ & $8.37 E-17$ \\
\hline Gd153 & $2.09 E+07$ & 5.52E-05 & $1.26 E-08$ \\
\hline Tb156 & $4.62 E+05$ & $2.91 E-45$ & $0.00 E+\infty$ \\
\hline 70157 & $4.73 E+09$ & $3.28 \mathrm{E}-05$ & $3.16 \mathrm{E}-05$ \\
\hline Tb158 & $4.73 E+09$ & $3.01 E-05$ & $2.90 \mathrm{E}-05$ \\
\hline Tb160 & $6.25 E+06$ & $3.90 E-06$ & $266 \mathrm{E}-18$ \\
\hline Tb161 & $5.96 \mathrm{E}+05$ & $0.00 E+\infty 0$ & $0.00 E+00$ \\
\hline Dy154 & $9.47 E+13$ & $1.79 E-09$ & $1.79 E-09$ \\
\hline Dy159 & $1.25 E+07$ & $2.59 E-04$ & $2.10 \mathrm{E}-10$ \\
\hline Ho163 & $1.44 \mathrm{E}+11$ & 4.31E-OG & $4.31 E-06$ \\
\hline Ho166* & $3.79 E+10$ & $5.45 E-07$ & $5.42 E-07$ \\
\hline Er169 & $8.04 E+05$ & $2.94 E-27$ & $0.00 E+00$ \\
\hline Tm168 & $8.04 E+06$ & $2.92 E-06$ & $1.04 \mathrm{E}-15$ \\
\hline Tm170 & $1.11 \mathrm{E}+07$ & $6.33 E-04$ & $9.15 E-11$ \\
\hline Tm171 & $6.06 E+07$ & $7.45 E-04$ & $4.15 E-05$ \\
\hline Yb169 & $2.77 E+06$ & 6.79E-09 & $2.25 E-36$ \\
\hline$L 172$ & $5.79 E+05$ & $1.07 \mathrm{E}-02$ & $5.49 \mathrm{E}-04$ \\
\hline 4173 & $4.32 \mathrm{E}+07$ & 8.21E-03 & $1.43 \mathrm{E}-04$ \\
\hline Lu174 & $1.05 E+08$ & $2.52 E-03$ & $4.76 \mathrm{E}-04$ \\
\hline $4174^{*}$ & $1.23 E+07$ & $1.55 E-04$ & $9.90 \mathrm{E}-11$ \\
\hline W176 & $1.14 \mathrm{E}+18$ & $5.64 E-14$ & $5.64 \mathrm{E}-14$ \\
\hline Lu177 & $5.80 E+05$ & 3.04E-07 & $1.04 \mathrm{E}-12$ \\
\hline$-41 \pi^{*}$ & $1.39 E+07$ & $1.39 E-06$ & $4.73 \mathrm{E}-12$ \\
\hline Hf172 & $5.90 E+07$ & 1.06E-02 & $5.44 \mathrm{E}-04$ \\
\hline Hf174 & $6.31 E+22$ & $2.86 E-17$ & $2.86 \mathrm{E}-17$ \\
\hline Hff175 & $6.05 E+06$ & $6.22 \mathrm{E}-05$ & $1.69 \mathrm{E}-17$ \\
\hline Hf178\# & $9.78 E+08$ & $7.04 E-09$ & $5.89 \mathrm{E}-09$ \\
\hline Hf179\# & $2.17 E+06$ & $5.22 E-13$ & $4.96 E-48$ \\
\hline
\end{tabular}




\begin{tabular}{|l|l|l|l|}
\hline$H+181$ & $3.66 E+06$ & $1.34 E-08$ & $2.40 E-29$ \\
\hline$H+182$ & $2.84 E+14$ & $1.17 E-12$ & $1.17 E-12$ \\
\hline
\end{tabular}




\begin{tabular}{|c|c|c|c|}
\hline Nuclide & Halfilfe,s & 2 years & 10 years \\
\hline Ta178 & $5.59 E+02$ & 4.97E-12 & $0.00 E+00$ \\
\hline Ta179 & $5.74 E+0 \overline{7}$ & $1.13 E-02$ & $5.38 \mathrm{E}-04$ \\
\hline Ta182 & $9.94 E+06$ & 5.82E-OS & $2.47 \mathrm{E}-12$ \\
\hline $\bar{W} 178$ & $1.87 \mathrm{E}+06$ & 4.97E-12 & $0.00 E+00$ \\
\hline W181 & $1.05 E+07$ & $1.41 \mathrm{E}-03$ & $7.81 E-11$ \\
\hline W185 & $6.49 E+06$ & $6.87 \mathrm{E}-07$ & $1.33 E-18$ \\
\hline W188 & $6.00 E+06$ & $3.02 E-10$ & $6.50 \mathrm{E}-23$ \\
\hline $\operatorname{Re183}$ & $6.05 E+06$ & $7.24 E-05$ & $1.99 \mathrm{E}-17$ \\
\hline $\operatorname{Re184}$ & $3.28 E+06$ & $1.30 E-05$ & $6.31 E-11$ \\
\hline Re184" & $1.43 E+07$ & $1.34 \mathrm{E}-05$ & $6.51 E-11$ \\
\hline $\operatorname{Re} 186$ & $3.26 E+05$ & $2.91 E-10$ & 2.91E-10 \\
\hline $\operatorname{Re} 186^{*}$ & $6.31 E+12$ & 2.91E-10 & $2.91 \mathrm{E}-10$ \\
\hline $\operatorname{Re187}$ & $1.58 E+18$ & $5.58 \mathrm{E}-14$ & $5.58 E-14$ \\
\hline $\operatorname{Re} 188$ & $6.11 E+04$ & $3.05 E-10$ & $0.00 E+00$ \\
\hline Os185 & $8.09 E+06$ & 8.37E-04 & $3.38 E-13$ \\
\hline $0 s 186$ & $6.00 E+22$ & 1.66E-16 & $1.66 \mathrm{E}-16$ \\
\hline Os191 & $1.33 E+06$ & $2.63 E-17$ & $0.00 E+00$ \\
\hline 05194 & $1.89 E+08$ & $6.63 \mathrm{E}-10$ & $2.63 E-10$ \\
\hline Ir192 & $6.38 E+06$ & $8.19 E-05$ & $5.09 E-06$ \\
\hline 17792\# & $7.60 E+09$ & $5.21 E-06$ & $5.09 E-06$ \\
\hline $1 r 193^{*}$ & $9.16 E+05$ & $7.38 \mathrm{E}-23$ & $0.00 E+00$ \\
\hline Ir194 & $6.89 E+04$ & $6.63 \mathrm{E}-10$ & $2.63 \mathrm{E}-10$ \\
\hline Ir194: & $1.48 E+07$ & $1.36 E-04$ & $9.95 E-10$ \\
\hline P4188 & $8.80 E+05$ & $2.75 E-23$ & $0.00 E+00$ \\
\hline$P 4190$ & $1.89 E+19$ & $3.14 E-13$ & $3.14 \mathrm{E}-13$ \\
\hline P4193 & $1.58 \mathrm{E}+09$ & $6.89 E-03$ & $6.17 E-03$ \\
\hline Au194 & $1.42 \mathrm{E}+06$ & $5.88 E-04$ & $5.82 \mathrm{E}-04$ \\
\hline Au195 & $1.61 \mathrm{E}+07$ & $1.79 \mathrm{E}-02$ & $3.36 E-07$ \\
\hline $\mathrm{Hg} 194$ & $1.64 \mathrm{E}+10$ & $5.88 E-04$ & $5.82 \mathrm{E}-04$ \\
\hline $\mathrm{Hg} 203$ & $4.03 E+06$ & $1.23 \mathrm{E}-0 \mathrm{G}$ & $1.66 E-25$ \\
\hline $\lg 206$ & $4.89 E+02$ & $2.26 E-17$ & $1.76 \mathrm{E}-17$ \\
\hline 1201 & $2.62 E+05$ & $3.52 E-73$ & $0.00 E+\infty 0$ \\
\hline 17202 & $1.06 E+06$ & 2.90E-05 & 2.89E-05 \\
\hline 1204 & $1.19 E+08$ & 9.47E-04 & $2.18 E-02$ \\
\hline 7206 & $2.52 \mathrm{E}+02$ & $2.02 E-12$ & $2.02 \mathrm{E}-12$ \\
\hline $\mathrm{Pb} 202$ & $1.66 E+12$ & $2.90 E-05$ & 2.89E-05 \\
\hline P6204 & $4.42 E+24$ & $1.08 E-15$ & $1.08 \mathrm{E}-15$ \\
\hline $\mathrm{Pb} 205$ & $4.80 E+14$ & $3.85 \mathrm{E}-07$ & $3.85 E-07$ \\
\hline $\mathrm{Pb210}$ & $7.04 E+08$ & $1.19 E-09$ & $9.29 \mathrm{E}-10$ \\
\hline$B 205$ & $1.32 E+06$ & $3.21 E-16$ & $0.00 E+00$ \\
\hline $8 ; 206$ & $5.39 \mathrm{E}+05$ & $3.23 \mathrm{E}-37$ & $0.00 E+00$ \\
\hline$B i 207$ & $1.02 E+09$ & $1.66 \mathrm{E}-03$ & $1.39 E-03$ \\
\hline$\overline{B i 208}$ & $1.16 E+13$ & $1.86 E-08$ & $1.86 E-08$ \\
\hline
\end{tabular}




\begin{tabular}{|l|l|l|r|}
\hline $8 i 209$ & $3.16 E+26$ & $9.32 E-21$ & $9.32 E-21$ \\
\hline$B 210$ & $4.33 E+05$ & $1.19 E-09$ & $9.29 E-10$ \\
\hline
\end{tabular}




\begin{tabular}{|c|c|c|c|}
\hline Nuclide & Halfife,s & 2 years & 10 years \\
\hline Bi210* & $9.47 E+13$ & $2.02 \mathrm{E}-12$ & $2.02 E-12$ \\
\hline Pa208 & $9.15 E+07$ & $2.39 E-11$ & $3.52 E-12$ \\
\hline$P 0209$ & $3.22 E+09$ & $1.53 \mathrm{E}-11$ & $1.45 E-11$ \\
\hline$P 0210$ & $1.20 E+07$ & $3.24 \mathrm{E}-07$ & $9.45 E-10$ \\
\hline Total & & $3.32 E-01$ & $1.29 \mathrm{E}-01$ \\
\hline
\end{tabular}

Generation: Modules will be replaced on a varying interval based on location in the cavity vessel.

Handling and Packaging: Modules will be stored in the Target Pool for radioactive decay and residual tritium accumulation. After target pool storage the modules will be placed in the Tritium Recovery Pit for tritium recovery . After tritium recovery the modules will be segregated and size reduced. The size reduced module segments will be placed into RCRA compliant disposal boxes in accordance with the EPA Debris rule and placed into a Satellite Area per RCRA requirements (40CFR262.34(c)).

Annual Quantities:

\begin{tabular}{|c|c|r|r|}
\hline Target Design & Waste Destination & Volume & Mass \\
\hline LiAl & $\begin{array}{c}\text { Mixed to Off-site Disposal/ On-Site } \\
\text { Storage }\end{array}$ & $15 \mathrm{~m}^{3}$ & $56,000 \mathrm{~kg}$ \\
\hline Helium-3 & $\begin{array}{c}\text { Mixed to Off-site Disposal/ On-Site } \\
\text { Storage }\end{array}$ & $12 \mathrm{~m}^{3}$ & $44,000 \mathrm{~kg}$ \\
\hline
\end{tabular}

Waste Minimization:

(a) Use of tungsten as the primary neutron source reduced lead requirements.

(b) The modules requiring high replacement rates have reduced amounts of lead.

(c) Tin and bismuth were investigated as a substitute for lead but significantly impacted the production rate.

Treatment Options:

(a) Macroencapsulation as debris.

\section{Comments:}




\section{B10. Nonhazardous Radioactive Oil}

Type: Radioactive Liquid Waste, Low-level Radioactive Waste.

Description: Lubricating oil in pumps and other mechanical systems may become contaminated with radionuclides. Oil can be contaminated with trace to significant amounts of the radionuclides listed in waste streams B4, B9, B11, B12, B15, B16, B17, B18, and B21. The actual radionuclides and concentration will vary depending where in the APT facility the oil is generated.

Generation: Waste oil is generated by preventative maintenance of oil pumps or compressors, chillers and gear boxes in radioactive areas.

Handling and Packaging: Most radioactive oil from the APT is expected to contain tritium oxide and spallation products. Radioactive, nonhazardous waste oil is stored in Radiological Material Areas (RMAs) in small carboys (plastic containers) in secondary containment. Later the oil will be consolidated in 13-gallon carboy. Once the carboy is filed, a representative sample is taken for analysis. Determine acceptability of the oil for the SRS Power House (tritium activity limit 2000 $\mathrm{pCi} / \mathrm{ml}$ ) or the $\mathrm{CIF}$ (tritium activity limit $3,417 \mathrm{nCi} / \mathrm{g}$ ). Package the waste oil/fluid for transportation to the Power House or CIF, using an absorbent in the overpack to capture any liquid spills.

\section{Annual Quantities:}

\begin{tabular}{|c|r|r|}
\hline Waste Destination & Volume & Mass \\
\hline $\begin{array}{c}\text { Liquid form to Power } \\
\text { House/CIF }\end{array}$ & $0.1 \mathrm{~m}^{3}$ & $90 \mathrm{~kg}$ \\
\hline $\begin{array}{c}\text { Stabilized waste form to } \\
\text { LAW Vaults }\end{array}$ & $0.2 \mathrm{~m}^{3}$ & $180 \mathrm{~kg}$ \\
\hline
\end{tabular}

(a) Assume 190 liters $/ y r, 50 \%$ to CIF and 50\% need to be stabilized.

(b) Assume 95 liters/yr stabilize to $2 \mathrm{x}$ volume.

(c) Assume $\mathrm{SpG}=1$ or $62.3 \mathrm{lb} / \mathrm{ft}^{3}$ for weight calculations, for both liquid and stabilized waste form.

Waste Minimization:

(a) Use of dry pumps (e.g. Normetex, Met-Bell) for tritium pumping.

(b) Use of oil-free blowers for discharges to stacks.

(c) Use water-cooled and lubricated cooling system pumps. 
Treatment Options:

(a) Energy recovery at the SRS Power House.

(b) Nonhazardous radioactive waste oil with tritium and other radionuclides concentrations meeting CIF WAC will be incinerated at the CIF.

(c) Stabilize and dispose in the EAV LAW Vaults.

\section{Comments:}

None. 


\section{B10a. Glovebox Bubbler Fluid}

Type: Radioactive Liquid Waste, Low-level Radioactive Waste.

Description: Glovebox bubblers contain a viscous liquid such as glycol or a silicone fluid. They are used as glovebox overpressure relief devices and also act as traps for removing contaminants from exiting glovebox atmosphere gases. The liquid in the bubblers is susceptible to tritium contamination. The liquids used in $233-\mathrm{H}$ glovebox bubblers are not currently regulated under RCRA as hazardous waste.

Generation: Bubblers are used as resealing pressure relief valves for gloveboxes. In the event of excessive glovebox pressure, gases will discharge through the bubblers rather than cause physical damage to the glovebox. Tritium in the glovebox atmosphere will readily exchange with the hydrogen atoms in the bubbler liquid. Tritium gloveboxes are normally maintained at a negative pressure relative to the room and tritium levels in the boxes are kept low. Therefore, little tritium activity should accumulate in the bubblers unless an overpressure occurs. Bubbler fluid in the Target/Blanket Facility may become contaminated with a wide range of spallation and activation radionuclides.

Handling and Packaging: See Waste Stream B11.

\section{Annual Quantities:}

\begin{tabular}{|c|r|r|}
\hline Waste Destination & Volume & Mass \\
\hline $\begin{array}{c}\text { Liquid form to Off-site } \\
\text { or CIF }\end{array}$ & $0.02 \mathrm{~m}^{3}$ & $18 \mathrm{~kg}$ \\
\hline $\begin{array}{c}\text { Stabilized waste form to } \\
\text { LAW Vaults }\end{array}$ & $0.04 \mathrm{~m}^{3}$ & $36 \mathrm{~kg}$ \\
\hline
\end{tabular}

(a) Assume 38 liters/yr, 50\% to Off-site and $50 \%$ need to be stabilized.

(b) Assume 19 liters/yr stabilize to $2 \mathrm{x}$ volume.

(c) Assume $\mathrm{SpG}=1$ or $62.3 \mathrm{lb} / \mathrm{ft}^{3}$ for weight calculations, for both liquid and stabilized waste form.

Waste Minimization:

There is no feasible substitute for using bubblers as glovebox pressure relief valves. 
Treatment Options:

(a) Stabilize bubbler liquid in an absorbent and send to EAV LAW Vaults for disposal..

(b) If tritium and halogen levels are acceptable, send to DSSI or SRS Power House for energy recovery or to SEG/CIF for incineration.

Comments:

(a) Mound Laboratory uses glycol in their bubblers; SRS uses a more expensive silicone fluid.

(b) Consider changing to glycol for cost effectiveness and disposability. 


\section{B11. Radioactive Light Water and Aqueous Solutions}

Type: Radioactive Liquid Waste.

Description: Water contaminated with varying amounts $(<20,000 \mathrm{pCi} / 1$ to $17 \mathrm{Ci} /)$ of tritiated water (tritium oxide). Other spallation radionuclides with varying characteristics may also be present. The following table lists the expected radionuclides in treated wastewater.

Figure B-1

APT Radioactive Liquid Waste Flow Diagram

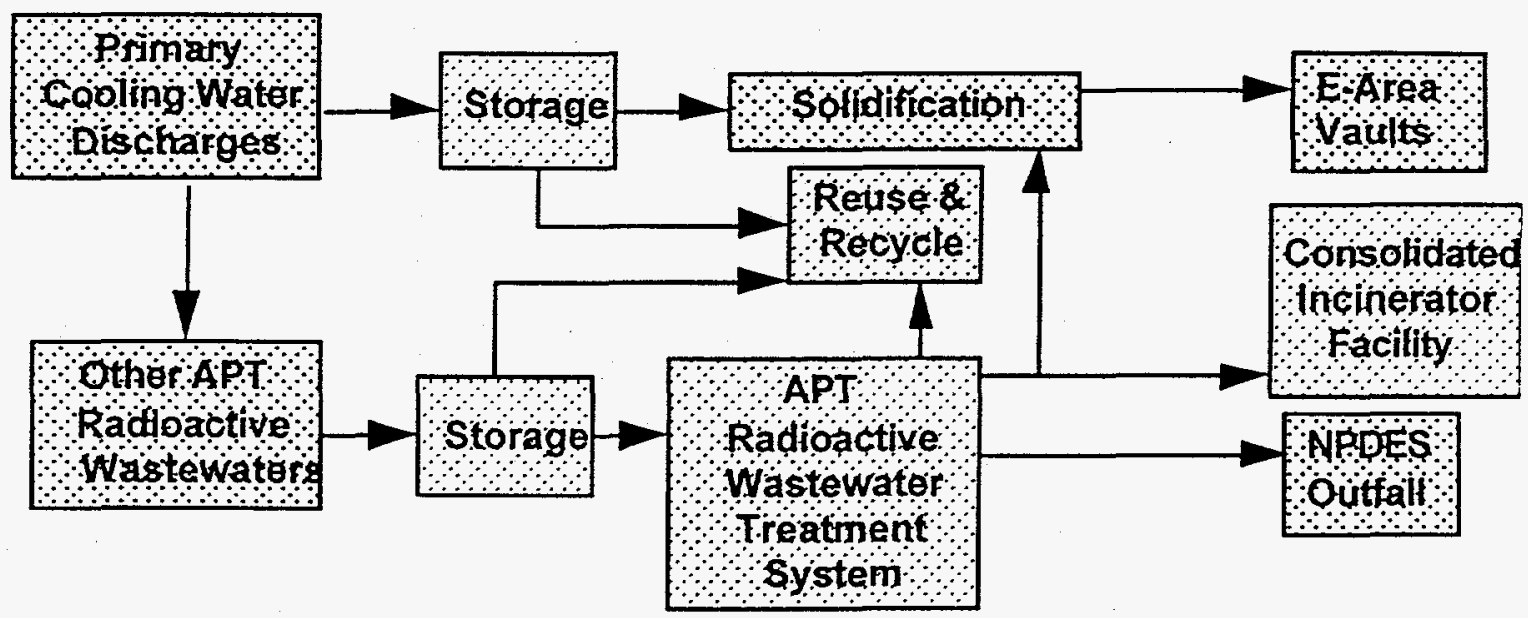

Light Water Discharge Average Nuclides in Ci/Liter

\begin{tabular}{|l|c|c|}
\hline \multicolumn{1}{|c|}{ Nuclide } & Half Life (s) & Ci/liter \\
\hline $\mathrm{Be}-7$ & $4.60 \mathrm{E}+06$ & $1.00 \mathrm{E}-08$ \\
\hline $\mathrm{H}-3$ & $3.89 \mathrm{E}+08$ & $2.00 \mathrm{E}-03$ \\
\hline $\mathrm{C} 0-57$ & $2.35 \mathrm{E}+07$ & $1.00 \mathrm{E}-11$ \\
\hline $\mathrm{C} 0-58$ & $6.13 \mathrm{E}+06$ & $2.00 \mathrm{E}-11$ \\
\hline $\mathrm{C} 0-60$ & $1.66 \mathrm{E}+08$ & $2.00 \mathrm{E}-10$ \\
\hline $\mathrm{Cr}-51$ & $2.39 \mathrm{E}+06$ & $4.00 \mathrm{E}-09$ \\
\hline $\mathrm{Fe}-55$ & $8.62 \mathrm{E}+07$ & $2.00 \mathrm{E}-11$ \\
\hline $\mathrm{Mn}-52$ & $4.83 \mathrm{E}+05$ & $2.00 \mathrm{E}-11$ \\
\hline $\mathrm{Mn}-54$ & $2.70 \mathrm{E}+07$ & $3.00 \mathrm{E}-11$ \\
\hline $\mathrm{Na}-22$ & $8.21 \mathrm{E}+07$ & $2.00 \mathrm{E}-09$ \\
\hline $\mathrm{P}-32$ & $1.23 \mathrm{E}+06$ & $1.00 \mathrm{E}-12$ \\
\hline $\mathrm{P}-33$ & $2.19 \mathrm{E}+06$ & $3.00 \mathrm{E}-11$ \\
\hline
\end{tabular}




\begin{tabular}{|l|l|l|}
\hline $\mathrm{V}-48$ & $1.38 \mathrm{E}+06$ & $1.00 \mathrm{E}-11$ \\
\hline $\mathrm{V}-49$ & $2.92 \mathrm{E}+07$ & $1.00 \mathrm{E}-11$ \\
\hline
\end{tabular}

Generation: 1) Activation, tritium contamination, and spallation contamination of primary and secondary cooling water; 2) T/B Pool water; 3) Spill control and contaminated rainwater; 4) Aqueous Analytical Lab/Rad Con counting cocktails; 5) Radioactive waste treatment secondary wastes; 6)Decontamination activities; 7) Air Emissions Treatment

Handling and Packaging: Send to the APT Liquid Radioactive Waste Treatment System (LRWS), store in tanks provided by APT for radioactive decay, or stabilize.

Annual Quantities:

\begin{tabular}{|c|r|}
\hline Waste Destination & Volume \\
\hline Long Term Tankage and/or Stabilization & 12,000 Liters \\
\hline APT LRWS & 500,000 Liters \\
\hline
\end{tabular}

a) Stabilization will double the volume of the wastewater from $12 \mathrm{~m}^{3}$ to $24 \mathrm{~m}^{3}$ for disposal in as a solid waste in a waste vault.

Waste Minimization:

a) Control cooling water chemistry to ensure water is not discharged until saturated to tritium levels.

b) Prevent rainwater inflow to radioactive areas.

c) Monitor groundwater with minimal extraction of actual samples.

d) Extract all primary coolant in modules and replace with clean coolant before placing modules into cooling pool.

e) Use nonwater based decontamination systems $\left(\mathrm{CO}_{2} \mathrm{Blasting}\right.$, etc.).

\section{Treatment Options:}

(a) For tritium and other non-removable radionuclides with levels acceptable to the APT LRWS send for processing and outfall. Current experience indicates that Analytical Lab/Rad Con counting cocktails may be discharged to the APT LRWS.

(b) For high tritium levels above NPDES release limits send to APT spent coolant tankage for radioactive decay.

(c) Stabilize to a solid wasteform and send to the EAV LAW Vaults for disposal.

(d) Use Z-Bed recovery system to process and recover highly tritiated water. 
(e) Use the CIF ashcrete system for stabilization

\section{Comments:}

Free liquid cannot be disposed of in the EAV. 


\section{B12. Radioactive Heavy Water Waste}

Type: Low-level Waste.

Description: Heavy water reaching the $17 \mathrm{Ci} / 1$ of tritium or other non-removable radionuclide or chemical contamination limits. The water will be treated to remove other radionuclides but may contain traces of APT generated radionuclides.

Generation: Generated during operation of the APT tungsten neutron source primary cooling loops as a slipstream product removed and polished but exceeding tritium limits or other physical/chemical limits.

Handling and Packaging: The heavy water will be transferred to the heavy water storage tank for radioactive decay.

Annual Quantities: 190 liters.

Waste Minimization:

a) None possible due the formation of tritium as a spallation product in the heavy water itself.

b) The heavy water will be stored until decay allows the reuse of the material.

Treatment Options:

The APT heavy water polishing system will remove most contaminants except tritium. Aging the waste for tritium decay and eventual reuse of this valuable commodity is the primary treatment option.

\section{Comments:}




\section{B13. Non-Radioactive Process Wastewater}

Type: Liquid Waste.

Description: Approximately $98 \%$ or more will be cooling water discharge with trace amounts of water treatment chemicals and TBD level of total dissolved solids. The water will be approximately $31^{\circ} \mathrm{C}$ at discharge point.

Generation: 1) Tertiary cooling loop for the Accelerator and T/B systems; 2) Klystron cooling; 3) rainwater infiltration; 4) Waste treatment secondary wastes; 5) Groundwater monitoring ; 6) groundwater infiltration

Handling and Packaging: Send to the APT Process Wastewater Treatment System (PWS) and discharge to an NPDES outfall.

\section{Annual Quantities:}

\begin{tabular}{|c|c|c|}
\hline Option & Waste Destination & Volume \\
\hline Superconducting & NPDES Outfall & $3,500,000,000$ Liters \\
\hline Room Temperature & NPDES Outfall & $4,800,000,000$ Liters \\
\hline
\end{tabular}

a) 300 operating days per year, 24 hours per day, and 8000 liters per minute (superconducting) or 11,000 liters per minute (room temperature).

Waste Minimization:

a) Control cooling water chemistry to ensure water is easily treated with minimal treatment chemicals.

b) Prevent rainwater inflow into APT facilities.

c) Monitor groundwater with minimal extraction of actual samples.

Treatment Options:

(a) Treat to meet NPDES requirements in the APT process wastewater system.

(b) Discharge directly to NPDES if water the meets permit limits.

\section{Comments:}


Figure B-2

APT Non-Radioactive Process Wastewater

Flow Diagram

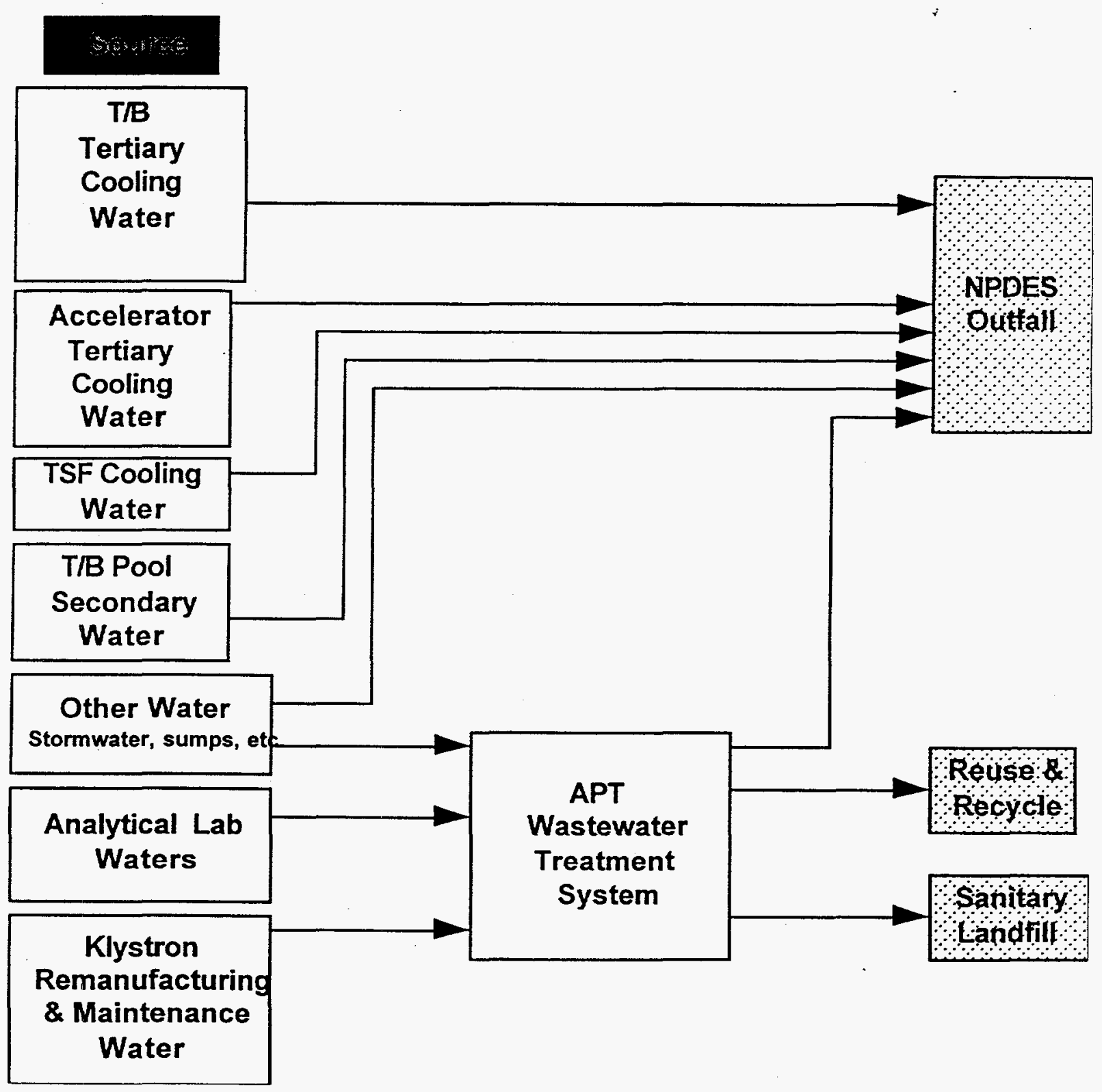




\section{B14. Sanitary and Industrial Waste}

Type: Sanitary and Industrial liquid and solid waste

Description: Liquid and solid sanitary and industrial waste containing no RCRA or TSCA wastes. This includes expired non-hazardous chemicals and biocides, failed non-recyclable equipment (e.g. pressure regulators, valves, fittings and tubing of non-radioactive water systems, power generation/distribution, etc.) and other sanitary/industrial wastes.

Generation: Generated by 650 personnel and plant operations. Remanufacture of klystrons and other accelerator equipment. Generated during administration, production, maintenance, or housekeeping activities in the APT non-radioactive areas.

\section{Annual Quantities:}

\begin{tabular}{|c|c|c|}
\hline Waste Category & Waste Destination & Volume/Mass \\
\hline $\begin{array}{c}\text { Sanitary Liquid Waste } \\
\text { (Li-Al option) }\end{array}$ & $\begin{array}{l}\text { SRS Wastewater } \\
\text { Treatment Plant }\end{array}$ & $14,700,000$ Liters \\
\hline $\begin{array}{c}\text { Sanitary Liquid Waste } \\
\text { (All other APT options) }\end{array}$ & $\begin{array}{l}\text { SRS Wastewater } \\
\text { Treatment Plant }\end{array}$ & $15,500,000$ Liters \\
\hline Sanitary Solid Waste & Sanitary Landfill & $2,200,000$ Kilograms \\
\hline Industrial Solid Waste & Industrial Landfill & $3,800,000$ Kilograms \\
\hline
\end{tabular}

Waste Minimization:

(a) Utilize "water miser" toilet systems.

(b) Utilize electronic document system.

(c) Recycle paper, glass, metals, plastics.

\section{Treatment Options:}

(a) Send to landfill or wastewater treatment.

\section{Comments:}




\section{B15. Tungsten}

Type: Low-level Radioactive Waste.

Description: This waste will be in the Tungsten Neutron Source used as neutron sources in the Target/Blanket cavity vessel. The modules will have two basic configurations depending on the region of origination in the cavity vessel. The tungsten portion of the modules will be on average $60 \%$ tungsten, $20 \%$ steel, and $20 \%$ void space. They will have been exposed to the proton beam and will be activated with numerous spallation products. Even though the tungsten neutron source may contain trace amounts of hazardous constituents (e.g. Cr) it will pass TCLP testing and remain a non-hazardous waste stream.

\section{Tungsten Maximum Average Nuclides in $\mathrm{Ci} / \mathrm{CC}$} (time period is from beam shutdown)

\begin{tabular}{|c|c|c|c|}
\hline Nuclide & Halflife,s & 5 years & 10 years \\
\hline $\begin{array}{ll}H \quad 3 \\
\end{array}$ & $3.89 E+08$ & $2.59 E+00$ & $1.96 E+00$ \\
\hline $\mathrm{Be} 7$ & $4.61 E+06$ & $2.53 \mathrm{E}-12$ & $1.22 \mathrm{E}-22$ \\
\hline $\mathrm{Be} 10$ & $5.05 E+13$ & $2.22 E-08$ & $2.22 \mathrm{E}-08$ \\
\hline C 14 & $1.81 E+11$ & $3.14 E-05$ & $3.14 E-05$ \\
\hline $\mathrm{Na} 22$ & $8.21 E+07$ & $1.38 E-03$ & $3.65 \mathrm{E}-04$ \\
\hline Al 26 & $2.27 E+13$ & $1.95 E-08$ & $1.95 E-08$ \\
\hline Si 32 & $5.43 E+09$ & $1.71 E-08$ & $1.67 E-08$ \\
\hline$P 32$ & $1.23 E+06$ & $1.71 E-08$ & $1.68 E-08$ \\
\hline 535 & $7.56 \mathrm{E}+06$ & $4.09 E-09$ & $2.13 E-15$ \\
\hline Cl 36 & $9.50 \mathrm{E}+12$ & $2.93 E-07$ & 2.93E-07 \\
\hline Ar 37 & $3.03 E+06$ & $2.80 E-18$ & $0.00 E+00$ \\
\hline Ar 39 & $8.49 E+09$ & $9.21 E-05$ & $9.10 \mathrm{E}-05$ \\
\hline Ar 42 & $1.04 E+09$ & $3.21 \mathrm{E}-09$ & $2.89 E-09$ \\
\hline $\mathrm{K} 40$ & $4.03 E+16$ & $7.12 \mathrm{E}-11$ & $7.12 \mathrm{E}-11$ \\
\hline K 42 & $4.45 E+04$ & $3.21 E-09$ & $2.89 E-09$ \\
\hline $\mathrm{Ca} 41$ & $3.25 E+12$ & $8.85 E-07$ & $8.85 E-07$ \\
\hline $\mathrm{Ca} 45$ & $1.42 \mathrm{E}+07$ & $3.14 \mathrm{E}-06$ & $1.38 \mathrm{E}-09$ \\
\hline Sc 44 & $1.41 \mathrm{E}+04$ & $2.03 E-04$ & $1.88 \mathrm{E}-04$ \\
\hline Sc 46 & $7.24 E+06$ & $1.04 \mathrm{E}-08$ & $2.86 \mathrm{E}-15$ \\
\hline Ii 44 & $1.49 E+09$ & $2.03 E-04$ & $1.88 \mathrm{E}-04$ \\
\hline$\sqrt{19}$ & $2.92 E+07$ & $3.57 E-03$ & $8.43 E-05$ \\
\hline $\mathrm{V} 50$ & $4.70 E+24$ & $2.08 E-18$ & $2.08 E-18$ \\
\hline Mn 53 & $1.18 \mathrm{E}+14$ & $1.93 E-07$ & $1.93 E-07$ \\
\hline Mn 54 & $2.70 \mathrm{E}+07$ & $7.20 \mathrm{E}-03$ & $1.25 \mathrm{E}-04$ \\
\hline Fe 55 & $8.62 E+07$ & 1.15E-01 & $3.23 E-02$ \\
\hline Fe 59 & $3.84 E+06$ & $4.88 E-15$ & $2.16 E-27$ \\
\hline Fe 60 & $4.73 E+13$ & $2.36 \mathrm{E}-09$ & $2.36 \mathrm{E}-09$ \\
\hline
\end{tabular}




\begin{tabular}{|c|c|c|c|}
\hline Nuclide & Halflife,s & 5 years & 10 years \\
\hline Co 56 & $6.80 E+06$ & $5.50 E-09$ & $5.75 E-16$ \\
\hline Co 57 & $2.35 E+07$ & $1.02 \mathrm{E}-03$ & $9.69 \mathrm{E}-06$ \\
\hline Co. 58 & $6.13 E+06$ & $2.83 \mathrm{E}-09$ & $5.01 \mathrm{E}-17$ \\
\hline Co 60 & $1.66 E+08$ & $3.36 \mathrm{E}-03$ & $1.74 E-03$ \\
\hline Co $60^{*}$ & $6.28 \mathrm{E}+02$ & $2.36 \mathrm{E}-09$ & $2.36 \mathrm{E}-09$ \\
\hline Ni 59 & $2.37 E+12$ & $3.15 \mathrm{E}-06$ & $3.15 E-06$ \\
\hline Ni 63 & $3.16 \mathrm{E}+09$ & $3.78 E-04$ & $3.66 \mathrm{E}-04$ \\
\hline $\mathrm{Zn} 65$ & $2.11 \mathrm{E}+07$ & $3.63 E-05$ & $2.02 E-07$ \\
\hline $\mathrm{Ga} 68$ & $4.06 \mathrm{E}+03$ & $1.49 E-05$ & 1.39E-07 \\
\hline Ge 68 & $2.34 \mathrm{E}+07$ & 1.49E-05 & 1.39E-07 \\
\hline As 73 & $6.94 E+06$ & $3.28 \mathrm{E}-09$ & $4.68 \mathrm{E}-16$ \\
\hline Se 75 & $1.03 E+07$ & $3.90 E-07$ & $1.00 \mathrm{E}-11$ \\
\hline Se 79 & $1.04 \mathrm{E}+12$ & $2.14 \mathrm{E}-07$ & $2.14 E-07$ \\
\hline $\mathrm{Kr} 81$ & $6.72 E+12$ & $2.30 \mathrm{E}-07$ & $2.30 E-07$ \\
\hline Kr 85 & $3.38 E+08$ & $9.20 \mathrm{E}-05$ & $6.66 E-05$ \\
\hline $\mathrm{Rb} 83$ & $7.45 E+06$ & $1.18 \mathrm{E}-08$ & $4.95 E-15$ \\
\hline $\mathrm{Rb} 84$ & $2.84 E+06$ & $1.34 \mathrm{E}-19$ & $2.53 E-36$ \\
\hline $\mathrm{Rb} 87$ & $1.51 \mathrm{E}+18$ & $8.55 \mathrm{E}-16$ & $8.55 E-16$ \\
\hline Sr 85 & $5.60 E+06$ & $7.25 \mathrm{E}-11$ & $2.41 \mathrm{E}-19$ \\
\hline Sr 89 & $4.37 E+06$ & $1.43 \mathrm{E}-16$ & $1.91 \mathrm{E}-27$ \\
\hline Sr 90 & $8.88 E+08$ & $1.06 \mathrm{E}-04$ & $9.40 \mathrm{E}-05$ \\
\hline $\bar{Y} 88$ & $9.21 \mathrm{E}+06$ & $3.28 \mathrm{E}-07$ & $2.35 \mathrm{E}-12$ \\
\hline Y90 & $2.31 E+05$ & $1.06 \mathrm{E}-04$ & $9.40 \mathrm{E}-05$ \\
\hline$\overline{Y 91}$ & $5.06 \mathrm{E}+06$ & $8.02 E-13$ & $3.22 \mathrm{E}-22$ \\
\hline$Z \mathrm{Zr} 88$ & $7.21 E+06$ & 2.47E-09 & $6.31 E-16$ \\
\hline $2 \mathrm{r} 93$ & $4.83 E+13$ & $1.03 \mathrm{E}-08$ & $1.03 \mathrm{E}-08$ \\
\hline $\mathrm{Zr95}$ & $5.53 E+06$ & $6.87 E-15$ & $1.78 \mathrm{E}-23$ \\
\hline Nb 91 & $2.15 \mathrm{E}+10$ & $2.04 E-05$ & $2.03 E-05$ \\
\hline $\mathrm{Nb} \mathrm{91^{* }}$ & $5.36 E+06$ & $4.89 E-14$ & $6.64 \mathrm{E}-23$ \\
\hline $\mathrm{Nb} 92$ & $1.10 \mathrm{E}+15$ & $2.15 \mathrm{E}-12$ & $2.15 \mathrm{E}-12$ \\
\hline $\mathrm{Nb} 93^{*}$ & $5.09 E+08$ & $3.01 \mathrm{E}-06$ & $2.44 E-06$ \\
\hline $\mathrm{Nb} 94$ & $6.41 E+11$ & $3.36 \mathrm{E}-07$ & $3.36 \mathrm{E}-07$ \\
\hline $\mathrm{Nb} 95$ & $3.02 E+06$ & $1.51 \mathrm{E}-14$ & $2.88 \mathrm{E}-30$ \\
\hline $\mathrm{Nb} 95^{*}$ & $3.12 E+05$ & $8.08 \mathrm{E}-17$ & $0.00 \mathrm{E}+00$ \\
\hline Mo 93 & $1.10 E+11$ & $2.23 E-08$ & $2.23 E-08$ \\
\hline Tc 95 & $7.20 E+04$ & $4.23 \mathrm{E}-17$ & $0.00 \mathrm{E}+00$ \\
\hline Tc $95^{*}$ & $5.27 E+06$ & $1.04 \mathrm{E}-15$ & $1.01 \mathrm{E}-24$ \\
\hline Tc 97 & $8.20 E+13$ & $7.58 \mathrm{E}-09$ & $7.58 \mathrm{E}-09$ \\
\hline Tc $97^{*}$ & $7.82 E+06$ & $5.04 \mathrm{E}-11$ & $4.25 \mathrm{E}-17$ \\
\hline Tc 98 & $1.33 E+14$ & $1.76 \mathrm{E}-09$ & $1.76 \mathrm{E}-09$ \\
\hline Tc 99 & $6.66 E+12$ & $6.78 \mathrm{E}-08$ & $6.78 \mathrm{E}-08$ \\
\hline
\end{tabular}




\begin{tabular}{|c|c|c|c|}
\hline Nuclide & Halflife,s & 5 years & 10 years \\
\hline Ru103 & $3.39 E+06$ & $4.03 E-17$ & $4.00 E-31$ \\
\hline Ru106 & $3.21 E+07$ & $3.77 E-11$ & $1.25 \mathrm{E}-12$ \\
\hline Rh101 & $1.04 E+08$ & $2.70 \mathrm{E}-03$ & $9.43 E-04$ \\
\hline Rh102 & $9.15 E+07$ & $7.73 E-04$ & $2.34 \mathrm{E}-04$ \\
\hline Rh102* & $1.79 E+07$ & $1.55 \mathrm{E}-06$ & $3.41 \mathrm{E}-09$ \\
\hline Rh103* & $3.37 \mathrm{E}+03$ & $4.02 E-17$ & $0.00 \mathrm{E}+00$ \\
\hline Rh106 & $2.98 E+01$ & $3.77 \mathrm{E}-11$ & $1.25 E-12$ \\
\hline Pd107 & $2.05 E+14$ & $5.34 \mathrm{E}-10$ & $5.34 E-10$ \\
\hline Ag105 & $3.57 E+06$ & $3.82 E-16$ & $1.84 E-29$ \\
\hline $\mathrm{Ag108}$ & $1.42 E+02$ & $2.42 E-08$ & $2.36 \mathrm{E}-08$ \\
\hline $\mathrm{Ag} 108^{*}$ & $4.01 E+09$ & $2.79 \mathrm{E}-07$ & $2.71 E-07$ \\
\hline $\mathrm{Ag} 109^{*}$ & $3.96 \mathrm{E}+01$ & $1.40 \mathrm{E}-03$ & 9.07E-05 \\
\hline $\mathrm{Ag} 110$ & $2.46 \mathrm{E}+01$ & $2.54 \mathrm{E}-08$ & $1.60 \mathrm{E}-10$ \\
\hline $\operatorname{Ag} 110^{*}$ & $2.16 E+07$ & 1.87E-06 & $1.18 \mathrm{E}-08$ \\
\hline Cd109 & $4.00 E+07$ & $1.40 \mathrm{E}-03$ & $9.07 E-05$ \\
\hline$\overline{\mathrm{Cd} 113}$ & $2.93 E+23$ & $1.23 E-19$ & $1.23 E-19$ \\
\hline Cd113* & $4.45 E+08$ & $1.97 E-06$ & $1.54 \mathrm{E}-06$ \\
\hline Cd115* & $3.85 E+06$ & $1.42 E-17$ & $6.71 \mathrm{E}-30$ \\
\hline $\ln 113^{*}$ & $5.97 E+03$ & $1.03 E-06$ & $1.72 \mathrm{E}-11$ \\
\hline $\ln 114$ & $7.19 E+01$ & $4.61 E-14$ & $0.00 \mathrm{E}+00$ \\
\hline $\ln 114^{*}$ & $4.28 E+06$ & $4.82 E-14$ & $3.79 \mathrm{E}-25$ \\
\hline $\ln 115$ & $1.39 E+22$ & $8.07 E-18$ & $8.07 E-18$ \\
\hline $5 n 113$ & $9.94 E+06$ & $1.03 E-06$ & $1.72 \mathrm{E}-11$ \\
\hline $\operatorname{Sn} 119^{*}$ & $2.53 E+07$ & $1.64 \mathrm{E}-05$ & $2.17 E-07$ \\
\hline$S n 121$ & $9.74 E+04$ & $4.04 \mathrm{E}-08$ & $3.79 E-08$ \\
\hline Sn121* & $1.74 E+09$ & $5.20 \mathrm{E}-08$ & $4.89 E-08$ \\
\hline Sn123 & $1.12 \mathrm{E}+07$ & $2.76 \mathrm{E}-12$ & $1.53 \mathrm{E}-16$ \\
\hline Sn126 & $3.16 \mathrm{E}+12$ & $3.64 \mathrm{E}-16$ & $3.64 \mathrm{E}-16$ \\
\hline$\widehat{S b 124}$ & $5.20 E+06$ & $6.02 E-15$ & $4.44 E-24$ \\
\hline$S b 125$ & $8.62 E+07$ & $3.30 \mathrm{E}-07$ & $9.29 \mathrm{E}-08$ \\
\hline Sb126 & $1.07 E+06$ & $5.10 E-17$ & $5.10 \mathrm{E}-17$ \\
\hline Sb126* & $1.14 E+03$ & $3.64 \mathrm{E}-16$ & $3.64 E-16$ \\
\hline Sb126\# & $1.10 E+01$ & $2.44 \mathrm{E}-16$ & $2.44 E-16$ \\
\hline Te121 & $1.45 \mathrm{E}+06$ & $6.88 \mathrm{E}-07$ & $1.85 \mathrm{E}-10$ \\
\hline Te121* & $1.33 E+07$ & $6.92 E-07$ & $1.86 \mathrm{E}-10$ \\
\hline Te123 & $3.91 \mathrm{E}+20$ & $7.46 \mathrm{E}-15$ & $7.46 E-15$ \\
\hline Te123* & $1.03 E+07$ & 1.27E-07 & $3.25 E-12$ \\
\hline Te125" & $5.01 E+06$ & $8.07 E-08$ & $2.27 \mathrm{E}-08$ \\
\hline Te127 & $3.37 E+04$ & $3.04 E-10$ & $2.75 E-15$ \\
\hline Te127" & $9.42 E+06$ & $3.10 \mathrm{E}-10$ & $2.81 E-15$ \\
\hline 125 & $5.20 E+06$ & $2.75 \mathrm{E}-10$ & $1.99 E-19$ \\
\hline 129 & $4.95 E+14$ & $2.19 E-10$ & $2.19 E-10$ \\
\hline
\end{tabular}




\begin{tabular}{|l|r|r|r|}
\hline Nuclide & Halflife,s & 5 years & 10 years \\
\hline Xe127 & $3.15 \mathrm{E}+06$ & $3.12 \mathrm{E}-16$ & $2.46 \mathrm{E}-31$ \\
\hline Cs134 & $6.51 \mathrm{E}+07$ & $4.48 \mathrm{E}-04$ & $8.34 \mathrm{E}-05$ \\
\hline Cs135 & $7.26 \mathrm{E}+13$ & $1.12 \mathrm{E}-10$ & $1.12 \mathrm{E}-10$ \\
\hline Cs137 & $9.47 \mathrm{E}+08$ & $6.71 \mathrm{E}-10$ & $5.98 \mathrm{E}-10$ \\
\hline Ba133 & $3.32 \mathrm{E}+08$ & $4.71 \mathrm{E}-02$ & $3.38 \mathrm{E}-02$ \\
\hline Ba137* & $1.53 \mathrm{E}+02$ & $6.34 \mathrm{E}-10$ & $5.65 \mathrm{E}-10$ \\
\hline La137 & $1.89 \mathrm{E}+12$ & $1.75 \mathrm{E}-05$ & $1.75 \mathrm{E}-05$ \\
\hline La138 & $3.31 \mathrm{E}+18$ & $8.08 \mathrm{E}-13$ & $8.08 \mathrm{E}-13$ \\
\hline Ce139 & $1.19 \mathrm{E}+07$ & $5.96 \mathrm{E}-05$ & $6.04 \mathrm{E}-09$ \\
\hline Ce144 & $2.46 \mathrm{E}+07$ & $1.49 \mathrm{E}-12$ & $1.75 \mathrm{E}-14$ \\
\hline Pr144 & $1.04 \mathrm{E}+03$ & $1.49 \mathrm{E}-12$ & $1.75 \mathrm{E}-14$ \\
\hline Pr144* & $4.32 \mathrm{E}+02$ & $2.08 \mathrm{E}-14$ & $2.45 \mathrm{E}-16$ \\
\hline Nd144 & $6.60 \mathrm{E}+22$ & $8.99 \mathrm{E}-17$ & $9.07 \mathrm{E}-17$ \\
\hline Nd145 & $1.89 \mathrm{E}+24$ & $4.46 \mathrm{E}-18$ & $7.93 \mathrm{E}-18$ \\
\hline Pm143 & $2.29 \mathrm{E}+07$ & $5.06 \mathrm{E}-03$ & $4.27 \mathrm{E}-05$ \\
\hline Pm144 & $3.14 \mathrm{E}+07$ & $1.74 \mathrm{E}-03$ & $5.36 \mathrm{E}-05$ \\
\hline Pm145 & $5.59 \mathrm{E}+08$ & $6.55 \mathrm{E}-02$ & $5.46 \mathrm{E}-02$ \\
\hline Pm146 & $1.75 \mathrm{E}+08$ & $6.40 \mathrm{E}-03$ & $3.42 \mathrm{E}-03$ \\
\hline Pm147 & $8.28 \mathrm{E}+07$ & $3.37 \mathrm{E}-03$ & $9.00 \mathrm{E}-04$ \\
\hline Pm148 & $4.64 \mathrm{E}+05$ & $1.33 \mathrm{E}-17$ & $0.00 \mathrm{E}+00$ \\
\hline Pm148* & $3.57 \mathrm{E}+06$ & $2.52 \mathrm{E}-16$ & $1.22 \mathrm{E}-29$ \\
\hline Sm145 & $2.94 \mathrm{E}+07$ & $1.54 \mathrm{E}-02$ & $3.71 \mathrm{E}-04$ \\
\hline Sm146 & $3.25 \mathrm{E}+15$ & $1.77 \mathrm{E}-08$ & $1.78 \mathrm{E}-08$ \\
\hline Sm147 & $3.35 \mathrm{E}+18$ & $1.11 \mathrm{E}-11$ & $1.12 \mathrm{E}-11$ \\
\hline Sm148 & $2.50 \mathrm{E}+23$ & $5.81 \mathrm{E}-17$ & $5.81 \mathrm{E}-17$ \\
\hline Sm149 & $6.31 \mathrm{E}+22$ & $1.59 \mathrm{E}-16$ & $1.59 \mathrm{E}-16$ \\
\hline Sm151 & $2.84 \mathrm{E}+09$ & $4.77 \mathrm{E}-04$ & $4.59 \mathrm{E}-04$ \\
\hline Eu146 & $3.97 \mathrm{E}+05$ & $3.03 \mathrm{E}-12$ & $1.24 \mathrm{E}-23$ \\
\hline Eu148 & $4.71 \mathrm{E}+06$ & $6.76 \mathrm{E}-12$ & $5.56 \mathrm{E}-22$ \\
\hline Eu149 & $8.04 \mathrm{E}+06$ & $1.07 \mathrm{E}-06$ & $1.33 \mathrm{E}-12$ \\
\hline Eu150 & $1.13 \mathrm{E}+09$ & $2.34 \mathrm{E}-03$ & $2.12 \mathrm{E}-03$ \\
\hline Eu152 & $4.21 \mathrm{E}+08$ & $1.60 \mathrm{E}-02$ & $1.23 \mathrm{E}-02$ \\
\hline Eu154 & $2.71 \mathrm{E}+08$ & $1.58 \mathrm{E}-02$ & $1.05 \mathrm{E}-02$ \\
\hline Eu155 & $1.48 \mathrm{E}+08$ & $2.38 \mathrm{E}-03$ & $1.13 \mathrm{E}-03$ \\
\hline Gd146 & $4.17 \mathrm{E}+06$ & $2.74 \mathrm{E}-12$ & $1.12 \mathrm{E}-23$ \\
\hline Gd148 & $2.09 \mathrm{E}+09$ & $1.71 \mathrm{E}-02$ & $1.64 \mathrm{E}-02$ \\
\hline Gd150 & $6.59 \mathrm{E}-07$ & $6.59 \mathrm{E}-07$ \\
\hline Gd15153 & $2.66 \mathrm{E}-05$ & $9.76 \mathrm{E}-10$ \\
\hline
\end{tabular}




\begin{tabular}{|c|c|c|c|}
\hline Nuclide & Halflife,s & 5 years & 10 years \\
\hline Tb157 & $4.73 E+09$ & $8.02 E-03$ & $7.84 E-03$ \\
\hline Tb158 & $4.73 E+09$ & $4.28 E-03$ & $4.18 \mathrm{E}-03$ \\
\hline Tb160 & $6.25 E+06$ & $7.16 \mathrm{E}-09$ & $1.78 E-16$ \\
\hline Dy 154 & $9.47 E+13$ & $4.33 E-07$ & $4.33 E-07$ \\
\hline Dy156 & $3.16 \mathrm{E}+25$ & $1.36 \mathrm{E}-18$ & $1.36 \mathrm{E}-18$ \\
\hline Dy159 & $1.25 E+07$ & $1.52 \mathrm{E}-04$ & $2.37 E-08$ \\
\hline Ho163 & $1.44 E+11$ & $4.37 E-04$ & $4.37 E-04$ \\
\hline Ho166* & $3.79 E+10$ & $2.06 \mathrm{E}-05$ & $2.05 E-05$ \\
\hline Tm168 & $8.04 E+06$ & $6.00 \mathrm{E}-08$ & $7.47 \mathrm{E}-14$ \\
\hline Tm170 & $1.11 \mathrm{E}+07$ & $6.17 \mathrm{E}-05$ & $3.28 E-09$ \\
\hline $\operatorname{Tm} 171$ & $6.06 E+07$ & $5.66 \mathrm{E}-03$ & $9.31 \mathrm{E}-04$ \\
\hline Yb169 & $2.77 E+06$ & $2.81 \mathrm{E}-17$ & $1.88 \mathrm{E}-34$ \\
\hline Lu172 & $5.79 E+05$ & $2.28 \mathrm{E}-01$ & $3.57 \mathrm{E}-02$ \\
\hline Lu173 & $4.32 \mathrm{E}+07$ & $1.55 \mathrm{E}-01$ & $1.23 E-02$ \\
\hline Lu174 & $1.05 E+08$ & $9.12 \mathrm{E}-02$ & $3.20 \mathrm{E}-02$ \\
\hline Lu174* & $1.23 E+07$ & $3.68 \mathrm{E}-05$ & $4.95 E-09$ \\
\hline Lu176 & $1.14 E+18$ & $1.01 \mathrm{E}-11$ & $1.01 \mathrm{E}-11$ \\
\hline LU177 & $5.80 \mathrm{E}+05$ & $8.18 E-08$ & $3.13 E-11$ \\
\hline Lu177* & $1.39 E+07$ & 3.73E-07 & $1.43 E-10$ \\
\hline $\mathrm{Hf172}$ & $5.90 \mathrm{E}+07$ & $2.26 \mathrm{E}-01$ & $3.54 \mathrm{E}-02$ \\
\hline Hf174 & $6.31 \mathrm{E}+22$ & $2.30 \mathrm{E}-15$ & $2.30 \mathrm{E}-15$ \\
\hline $\mathrm{Hf175}$ & $6.05 E+06$ & $6.95 E-08$ & $9.73 E-16$ \\
\hline Hf178\# & $9.78 E+08$ & 5.09E-06 & $4.55 E-06$ \\
\hline Hf181 & $3.66 \mathrm{E}+06$ & $5.43 E-14$ & $5.88 \mathrm{E}-27$ \\
\hline Hf182 & $2.84 E+14$ & $3.52 \mathrm{E}-08$ & $3.52 \mathrm{E}-08$ \\
\hline Ta179 & $5.74 E+07$ & 6.49E-01 & $9.67 E-02$ \\
\hline Ta182 & $9.94 E+06$ & $6.82 \mathrm{E}-05$ & $3.64 E-08$ \\
\hline W 181 & $1.05 E+07$ & 5.77E-04 & $1.68 \mathrm{E}-08$ \\
\hline W 185 & $6.49 \mathrm{E}+06$ & 3.92E-06 & $1.88 E-13$ \\
\hline W 188 & $6.00 E+06$ & $1.74 \mathrm{E}-10$ & $2.11 E-18$ \\
\hline $\operatorname{Re} 183$ & $6.05 E+06$ & 6.44E-09 & $9.08 E-17$ \\
\hline $\operatorname{Re} 184$ & $3.28 \mathrm{E}+06$ & 9.15E-06 & $4.36 \mathrm{E}-09$ \\
\hline $\operatorname{Re184^{*}}$ & $1.43 E+07$ & 9.44E-06 & $4.50 E-09$ \\
\hline $\operatorname{Re186}$ & $3.26 \mathrm{E}+05$ & $1.02 \mathrm{E}-06$ & $1.02 E-06$ \\
\hline$\overline{\operatorname{Re} 186^{*}}$ & $6.31 \mathrm{E}+12$ & $1.02 E-06$ & $1.02 E-06$ \\
\hline $\operatorname{Re} 187$ & $1.58 \mathrm{E}+18$ & 5.56E-09 & $5.56 \mathrm{E}-09$ \\
\hline $\operatorname{Re} 188$ & $6.11 \mathrm{E}+04$ & $1.76 \mathrm{E}-10$ & $2.13 E-18$ \\
\hline Os185 & $8.09 E+06$ & $1.15 \mathrm{E}-07$ & $1.55 \mathrm{E}-13$ \\
\hline Os186 & $6.00 \mathrm{E}+22$ & $2.15 E-14$ & $2.15 E-14$ \\
\hline$\overline{0 s 194}$ & $1.89 E+08$ & $5.83 E-13$ & $3.27 E-13$ \\
\hline
\end{tabular}




\begin{tabular}{|l|r|r|r|}
\hline Nuclide & \multicolumn{1}{|l|}{ Halflife,s } & 5 years & 10 years \\
\hline Ir192 & $6.38 \mathrm{E}+06$ & $2.08 \mathrm{E}-07$ & $2.05 \mathrm{E}-07$ \\
\hline Ir192\# & $7.60 \mathrm{E}+09$ & $2.08 \mathrm{E}-07$ & $2.05 \mathrm{E}-07$ \\
\hline Ir194 & $6.89 \mathrm{E}+04$ & $5.83 \mathrm{E}-13$ & $3.27 \mathrm{E}-13$ \\
\hline Ir194* & $1.48 \mathrm{E}+07$ & $1.42 \mathrm{E}-09$ & $8.75 \mathrm{E}-13$ \\
\hline Pt193 & $1.58 \mathrm{E}+09$ & $3.51 \mathrm{E}-07$ & $3.27 \mathrm{E}-07$ \\
\hline Total Ci/CC & & $4.30 \mathrm{E}+00$ & $2.36 \mathrm{E}+00$ \\
\hline
\end{tabular}

Generation: Modules will be replaced every year or every other year based on location in the cavity vessel.

Handling and Packaging: Modules will be stored in the Target Pool for radioactive decay and residual tritium accumulation. After target pool storage the modules will be placed in the Tritium Recovery Cell for tritium recovery. After tritium recovery the modules will be segregated and size reduced. The size reduced tungsten segments will be placed into disposal boxes in accordance with the waste acceptance criteria in the E-Area Vaults.

Annual Quantities:

\begin{tabular}{|c|c|r|r|}
\hline Target Design & Waste Destination & Volume & Mass \\
\hline LiAl & TBD & $2 \mathrm{~m}^{3}$ & $1100 \mathrm{~kg}$ \\
\hline Helium-3 & TBD & $2 \mathrm{~m}^{3}$ & $1100 \mathrm{~kg}$ \\
\hline
\end{tabular}

Waste Minimization:

(a) Use of tungsten as the primary neutron source reduced lead requirements.

(b) Module concept was used to decrease the waste generated on an annual basis.

Treatment Options:

(a) Package for LLRW disposal.

Comments: 


\section{B16. Window Modules}

Type: Low-level Radioactive Waste.

Description: Window module used between the accelerator and Target/Blanket cavity vessel.. The module will be on average $80 \%$ Inconel and $20 \%$ void space. They will have been exposed to the proton beam and will be activated with numerous spallation products. Even though the Inconel may contain trace amounts of hazardous constituents (e.g. Cr) it will pass TCLP testing and remain a non-hazardous waste stream.

Window Module Maximum Average Nuclides in Ci/CC (time period is from beam shutdown)

\begin{tabular}{|c|c|c|c|}
\hline Nuclide & Halfife,s & 5 years & 10 years \\
\hline H 3 & $3.8910 \mathrm{E}+08$ & $1.3572 \mathrm{E}+00$ & $1.0246 \mathrm{E}+00$ \\
\hline $\mathrm{Be} 7$ & $4.6051 E+06$ & $1.3379 \mathrm{E}-11$ & $6.4865 \mathrm{E}-22$ \\
\hline Be 10 & $5.049 \mathrm{IE}+13$ & $1.8556 \mathrm{E}-08$ & $1.8556 \mathrm{E}-08$ \\
\hline C 14 & $1.8082 \mathrm{E}+11$ & $1.0317 \mathrm{E}-05$ & $1.0311 \mathrm{E}-05$ \\
\hline $\mathrm{Na} 22$ & $8.2111 \mathrm{E}+07$ & $8.4067 E-02$ & $2.2190 \mathrm{E}-02$ \\
\hline Al 26 & $2.2721 E+13$ & $1.6113 \mathrm{E}-06$ & $1.6113 E-06$ \\
\hline Si 32 & $5.4279 E+09$ & $3.1922 \mathrm{E}-08$ & $3.1285 E-08$ \\
\hline P 32 & $1.2321 \mathrm{E}+06$ & $3.1929 \mathrm{E}-08$ & $3.1292 \mathrm{E}-08$ \\
\hline 535 & $7.5600 \mathrm{E}+06$ & $4.1984 \mathrm{E}-07$ & $2.1885 E-13$ \\
\hline $\mathrm{Cl} 36$ & $9.4986 \mathrm{E}+12$ & $7.7528 \mathrm{E}-06$ & $7.7528 \mathrm{E}-06$ \\
\hline Ar 37 & $3.0275 \mathrm{E}+06$ & $6.4794 \mathrm{E}-16$ & $.0000 \mathrm{E}+00$ \\
\hline Ar 39 & $8.4888 E+09$ & $2.3749 \mathrm{E}-03$ & $2.3445 \mathrm{E}-03$ \\
\hline Ar 42 & $1.0382 \mathrm{E}+09$ & $2.6077 \mathrm{E}-09$ & $2.3469 \mathrm{E}-09$ \\
\hline K 40 & $4.0298 E+16$ & $1.6881 \mathrm{E}-09$ & $1.6881 \mathrm{E}-09$ \\
\hline K 42 & $4.4496 \mathrm{E}+04$ & $2.6078 \mathrm{E}-09$ & $2.3470 \mathrm{E}-09$ \\
\hline$\overline{\mathrm{Ca} 41}$ & $3.2504 \mathrm{E}+12$ & $1.5482 \mathrm{E}-05$ & $1.5482 \mathrm{E}-05$ \\
\hline$\overline{\mathrm{Ca} 45}$ & $1.4152 \mathrm{E}+07$ & $5.3114 \mathrm{E}-05$ & $2.3381 E-08$ \\
\hline Sc 44 & $1.4137 \mathrm{E}+04$ & $6.3482 \mathrm{E}-03$ & $5.8997 \mathrm{E}-03$ \\
\hline Sc 46 & $7.2412 E+06$ & $7.0404 \mathrm{E}-07$ & 1.9411E-13 \\
\hline Ti 44 & $1.4926 \mathrm{E}+09$ & $6.3482 \mathrm{E}-03$ & $5.8997 \mathrm{E}-03$ \\
\hline V 49 & $2.9203 \mathrm{E}+07$ & $9.2299 \mathrm{E}-02$ & $2.1812 \mathrm{E}-03$ \\
\hline V 50 & $4.7000 \mathrm{E}+24$ & $1.8599 \mathrm{E}-17$ & $1.8599 \mathrm{E}-17$ \\
\hline $\mathrm{Mn} 53$ & $1.1802 \mathrm{E}+14$ & $1.0098 \mathrm{E}-06$ & $1.0098 \mathrm{E}-06$ \\
\hline $\operatorname{Mn} 54$ & $2.6967 \mathrm{E}+07$ & $4.520 \mathrm{IE}-02$ & $7.8302 \mathrm{E}-04$ \\
\hline Fe 55 & $8.6150 \mathrm{E}+07$ & $6.8692 \mathrm{E}-01$ & $1.9300 \mathrm{E}-01$ \\
\hline$\overline{F e} 59$ & $3.8445 \mathrm{E}+06$ & $3.4132 \mathrm{E}-14$ & $1.5071 \mathrm{E}-26$ \\
\hline $\mathrm{Fe} 60$ & $4.7335 \mathrm{E}+13$ & $1.9774 \mathrm{E}-08$ & $1.9774 \mathrm{E}-08$ \\
\hline $\operatorname{Co} 56$ & $6.8049 \mathrm{E}+06$ & $7.3699 \mathrm{E}-07$ & $7.7154 \mathrm{E}-14$ \\
\hline $\operatorname{Cos} 5$ & $2.3484 E+07$ & $1.1203 \mathrm{E}-0 \mathrm{I}$ & $1.0634 \mathrm{E}-03$ \\
\hline $\cos 8$ & $6.1271 \mathrm{E}+06$ & $1.5897 \mathrm{E}-07$ & $2.8122 \mathrm{E}-15$ \\
\hline $\operatorname{Co} 60$ & $1.6635 \mathrm{E}+08$ & $1.1214 \mathrm{E}-01$ & $5.8108 \mathrm{E}-02$ \\
\hline $\mathrm{Co} 60^{*}$ & $6.2820 \mathrm{E}+02$ & $1.9774 \mathrm{E}-08$ & $1.9774 \mathrm{E}-08$ \\
\hline Ni 59 & $2.3668 \mathrm{E}+12$ & $5.0596 \mathrm{E}-05$ & $5.0594 \mathrm{E}-05$ \\
\hline Ni 63 & $3.1588 \mathrm{E}+09$ & $3.6001 \mathrm{E}-03$ & $3.4776 \mathrm{E}-03$ \\
\hline $\operatorname{Zn} 65$ & $2.1073 \mathrm{E}+07$ & $1.1979 \mathrm{E}-03$ & $6.6744 \mathrm{E}-06$ \\
\hline Ga 68 & $4.0577 \mathrm{E}+03$ & $2.6725 \mathrm{E}-04$ & $2.4944 \mathrm{E}-06$ \\
\hline Ge 68 & $2.3399 \mathrm{E}+07$ & $2.6720 \mathrm{E}-04$ & $2.4939 \mathrm{E}-06$ \\
\hline As 73 & $6.9380 \mathrm{E}+06$ & $3.6710 \mathrm{E}-08$ & $5.2310 \mathrm{E}-15$ \\
\hline Se 75 & $1.0348 \mathrm{E}+07$ & $6.9763 \mathrm{E}-06$ & $1.7925 \mathrm{E}+10$ \\
\hline Se 79 & $1.0414 \mathrm{E}+12$ & $9.9035 \mathrm{E}-11$ & $9.9024 \mathrm{E}-11$ \\
\hline Kr 81 & $6.7216 \mathrm{E}+12$ & $8.3217 \mathrm{E}-07$ & $8.3215 \mathrm{E}-07$ \\
\hline
\end{tabular}




\begin{tabular}{|l|l|l|l|}
\hline $\mathrm{Kr} 85$ & $3.3829 \mathrm{E}+08$ & $3.0853 \mathrm{E}-08$ & $2.2330 \mathrm{E}-08$ \\
\hline
\end{tabular}




\begin{tabular}{|c|c|c|c|}
\hline Nuclide & Halnife,s & 5 years & 10 years \\
\hline $\mathrm{Rb} 83$ & $7.4480 \mathrm{E}+06$ & $1.0612 \mathrm{E}-07$ & $4.4502 \mathrm{E}-14$ \\
\hline $\mathrm{Rb} 87$ & $1.5147 \mathrm{E}+18$ & $1.4318 \mathrm{E}-17$ & $1.4318 \mathrm{E}-17$ \\
\hline Sr 85 & $5.6022 \mathrm{E}+06$ & $1.9653 \mathrm{E}-09$ & $6.5286 \mathrm{E}-18$ \\
\hline Sr 89 & $4.3675 \mathrm{E}+06$ & $7.9752 \mathrm{E}-17$ & $1.0622 \mathrm{E}-27$ \\
\hline Sr 90 & $8.8833 \mathrm{E}+08$ & $2.0545 E-09$ & $1.8165 \mathrm{E}-09$ \\
\hline Y 88 & $9.2102 E+06$ & $1.4827 \mathrm{E}-05$ & $1.0607 \mathrm{E}-10$ \\
\hline Y 90 & $2.3076 \mathrm{E}+05$ & $2.0550 \mathrm{E}-09$ & $1.8169 \mathrm{E}-09$ \\
\hline Y 91 & $5.0553 \mathrm{E}+06$ & $3.7298 \mathrm{E}-15$ & $1.4991 \mathrm{E}-24$ \\
\hline Zr 88 & $7.2058 \mathrm{E}+06$ & $1.1747 \mathrm{E}-07$ & $3.0073 \mathrm{E}-14$ \\
\hline Zr 93 & $4.8282 \mathrm{E}+13$ & $2.8134 \mathrm{E}-08$ & $2.8134 \mathrm{E}-08$ \\
\hline Zr95 & $5.5313 \mathrm{E}+06$ & $1.0096 \mathrm{E}-12$ & $2.6112 \mathrm{E}-21$ \\
\hline Nb 91 & $2.1459 \mathrm{E}+10$ & $8.6117 \mathrm{E}-04$ & $8.5680 \mathrm{E}-04$ \\
\hline $\mathrm{Nb} 91^{*}$ & $5.3568 \mathrm{E}+06$ & $2.2227 \mathrm{E}-12$ & $3.0190 \mathrm{E}-21$ \\
\hline $\mathrm{Nb} 92$ & $1.1045 \mathrm{E}+15$ & 1.9891E-08 & $1.9891 \mathrm{E}-08$ \\
\hline $\mathrm{Nb} 93^{*}$ & $5.0901 \mathrm{E}+08$ & $1.1356 \mathrm{E}-02$ & $9.1640 \mathrm{E}-03$ \\
\hline Nb 94 & $6.4061 \mathrm{E}+11$ & $1.8669 \mathrm{E}-05$ & $1.8666 \mathrm{E}-05$ \\
\hline $\mathrm{Nb} 95$ & $3.0214 \mathrm{E}+06$ & $2.2249 \mathrm{E}-12$ & $5.6906 \mathrm{E}-21$ \\
\hline $\mathrm{Nb} 95^{\circ}$ & $3.1190 \mathrm{E}+05$ & $1.1876 \mathrm{E}-14$ & $3.0716 \mathrm{E}-23$ \\
\hline Mo 93 & $1.1045 \mathrm{E}+11$ & $2.1820 \mathrm{E}-05$ & $2.1798 \mathrm{E}-05$ \\
\hline Tc 95* & $5.2700 \mathrm{E}+06$ & $2.8166 \mathrm{E}-17$ & $2.7330 \mathrm{E}-26$ \\
\hline Tc 97 & $8.2048 \mathrm{E}+13$ & $8.3894 \mathrm{E}-14$ & $8.3894 \mathrm{E}-14$ \\
\hline Tc 97* & $7.8192 \mathrm{E}+06$ & $8.3148 \mathrm{E}-14$ & $7.0017 \mathrm{E}-20$ \\
\hline Tc 98 & $1.3254 \mathrm{E}+14$ & $1.3930 \mathrm{E}-12$ & $1.3930 \mathrm{E}-12$ \\
\hline Tc 99 & $6.6617 \mathrm{E}+12$ & $2.4245 \mathrm{E}-07$ & $2.4244 \mathrm{E}-07$ \\
\hline Rhl02 & $9.1454 E+07$ & $1.1117 \mathrm{E}-16$ & $3.3622 \mathrm{E}-17$ \\
\hline Total & & $6.7746 \mathrm{E}+00$ & $2.5227 \mathrm{E}+00$ \\
\hline
\end{tabular}

Generation: Window Modules will be replaced annually.

Handling and Packaging: Window modules will be stored in the Target Pool for radioactive decay. The cooled module will be placed into disposal boxes in accordance with the waste acceptance criteria in the E-Area Vaults.

Annual Quantities:

\begin{tabular}{|c|c|r|r|}
\hline Target Design & Waste Destination & Volume & Mass \\
\hline LiAl & TBD & $0.5 \mathrm{~m}^{3}$ & $100 \mathrm{~kg}$ \\
\hline Helium-3 & TBD & $0.5 \mathrm{~m}^{3}$ & $100 \mathrm{~kg}$ \\
\hline
\end{tabular}

\section{Waste Minimization:}

(a) Substitute tantalum for niobium in the Inconel 718 to reduce the amount of $\mathrm{Nb} 94$ produced.

\section{Treatment Options:}

(a) Package for LLRW disposal. 


\section{Comments:}




\section{B17. Steel Shielding}

Type: Low-level Radioactive Waste.

Description: Axial steel shielding used on T/B modules.. The steel shielding will be on average $85 \%$ steel and $15 \%$ void space. They will have been exposed to the cavity vessel environment and will be activated with numerous spallation products. Even though the steel may contain trace amounts of hazardous constituents (e.g. $\mathrm{Cr}$ ) it will pass TCLP testing and remain a nonhazardous waste stream.

Steel Shielding Maximum Average Nuclides in Ci/CC (time period is from beam shutdown)

\begin{tabular}{|c|c|c|c|}
\hline Nuclide & Halnife,s & 5 years & 10 years \\
\hline $\begin{array}{ll}3 \\
\end{array}$ & $3.8910 \mathrm{E}+08$ & $1.3572 \mathrm{E}+00$ & $1.0246 \mathrm{E}+00$ \\
\hline $\mathrm{Be} 7$ & $4.6051 E+06$ & $1.3379 \mathrm{E}-11$ & $6.4865 \mathrm{E}-22$ \\
\hline $\mathrm{Be} 10$ & $5.0491 E+13$ & $1.8556 \mathrm{E}-08$ & $1.8556 \mathrm{E}-08$ \\
\hline C 14 & $1.8082 \mathrm{E}+11$ & $1.0317 \mathrm{E}-05$ & $1.0311 \mathrm{E}-05$ \\
\hline $\mathrm{Na} 22$ & $8.2111 E+07$ & $8.4067 \mathrm{E}-02$ & $2.2190 \mathrm{E}-02$ \\
\hline Al 26 & $2.2721 \mathrm{E}+13$ & $1.6113 E-06$ & $1.6113 \mathrm{E}-06$ \\
\hline Si 32 & $5.4279 E+09$ & $3.1922 \mathrm{E}-08$ & $3.1285 \mathrm{E}-08$ \\
\hline P 32 & $1.2321 \mathrm{E}+06$ & $3.1929 \mathrm{E}-08$ & $3.1292 \mathrm{E}-08$ \\
\hline S 35 & $7.5600 \mathrm{E}+06$ & $4.1984 \mathrm{E}-07$ & $2.1885 \mathrm{E}-13$ \\
\hline $\mathrm{Cl} 36$ & $9.4986 \mathrm{E}+12$ & $7.7528 \mathrm{E}-06$ & $7.7528 \mathrm{E}-06$ \\
\hline Ar 37 & $3.0275 \mathrm{E}+06$ & $6.4794 \mathrm{E}-16$ & $.0000 \mathrm{E}+00$ \\
\hline Ar 39 & $8.4888 \mathrm{E}+09$ & $2.3749 \mathrm{E}-03$ & $2.3445 E-03$ \\
\hline Ar 42 & $1.0382 \mathrm{E}+09$ & $2.6077 \mathrm{E}-09$ & $2.3469 \mathrm{E}-09$ \\
\hline K 40 & $4.0298 \mathrm{E}+16$ & $1.6881 \mathrm{E}-09$ & $1.6881 E-09$ \\
\hline K 42 & $4.4496 \mathrm{E}+04$ & $2.6078 \mathrm{E}-09$ & $2.3470 \mathrm{E}-09$ \\
\hline $\mathrm{Ca} 41$ & $3.2504 \mathrm{E}+12$ & $1.5482 \mathrm{E}-05$ & $1.5482 \mathrm{E}-05$ \\
\hline $\mathrm{Ca} 45$ & $1.4152 \mathrm{E}+07$ & $5.3114 \mathrm{E}-05$ & $2.3381 E-08$ \\
\hline Sc 44 & $1.4137 \mathrm{E}+04$ & $6.3482 E-03$ & $5.8997 \mathrm{E}-03$ \\
\hline Sc 46 & $7.2412 \mathrm{E}+06$ & $7.0404 \mathrm{E}-07$ & $1.9411 \mathrm{E}-13$ \\
\hline Ti44 & $1.4926 \mathrm{E}+09$ & $6.3482 E-03$ & $5.8997 \mathrm{E}-03$ \\
\hline V 49 & $2.9203 \mathrm{E}+07$ & $9.2299 \mathrm{E}-02$ & $2.1812 \mathrm{E}-03$ \\
\hline V 50 & $4.7000 \mathrm{E}+24$ & $1.8599 \mathrm{E}-17$ & $1.8599 \mathrm{E}-17$ \\
\hline Mn 53 & $1.1802 \mathrm{E}+14$ & $1.0098 \mathrm{E}-06$ & $1.0098 \mathrm{E}-06$ \\
\hline Mn 54 & $2.6967 E+07$ & $4.5201 \mathrm{E}-02$ & $7.8302 \mathrm{E}-04$ \\
\hline Fe 55 & $8.6150 \mathrm{E}+07$ & $6.8692 \mathrm{E}-01$ & $1.9300 \mathrm{E}-01$ \\
\hline Fe 59 & $3.8445 \mathrm{E}+06$ & $3.4132 \mathrm{E}-14$ & $1.5071 \mathrm{E}-26$ \\
\hline $\mathrm{Fe} 60$ & $4.7335 \mathrm{E}+13$ & $1.9774 \mathrm{E}-08$ & $1.9774 \mathrm{E}-08$ \\
\hline Co 56 & $6.8049 \mathrm{E}+06$ & $7.3699 \mathrm{E}-07$ & $7.7154 \mathrm{E}-14$ \\
\hline Co 57 & $2.3484 \mathrm{E}+07$ & $1.1203 \mathrm{E}-01$ & $1.0634 \mathrm{E}-03$ \\
\hline Co 58 & $6.1271 E+06$ & $1.5897 \mathrm{E}-07$ & $2.8122 \mathrm{E}-15$ \\
\hline Co 60 & $1.6635 \mathrm{E}+08$ & $1.1214 \mathrm{E}-01$ & $5.8108 \mathrm{E}-02$ \\
\hline Ni 59 & $2.3668 \mathrm{E}+12$ & $5.0596 \mathrm{E}-05$ & $5.0594 \mathrm{E}-05$ \\
\hline $\mathrm{Ni} 63$ & $3.1588 \mathrm{E}+09$ & $3.6001 E-03$ & $3.4776 \mathrm{E}-03$ \\
\hline $\operatorname{Zn~} 65$ & $2.1073 \mathrm{E}+07$ & $1.1979 \mathrm{E}-03$ & $6.6744 \mathrm{E}-06$ \\
\hline Ge 68 & $2.3399 \mathrm{E}+07$ & $2.6720 \mathrm{E}-04$ & $2.4939 \mathrm{E}-06$ \\
\hline As 73 & $6.9380 \mathrm{E}+06$ & $3.6710 \mathrm{E}-08$ & $5.2310 \mathrm{E}-15$ \\
\hline Se 75 & $1.0348 E+07$ & $6.9763 E-06$ & $1.7925 \mathrm{E}-10$ \\
\hline Se 79 & $1.0414 \mathrm{E}+12$ & $9.9035 \mathrm{E}-11$ & $9.9024 \mathrm{E}-11$ \\
\hline $\mathrm{Kr} 81$ & $6.7216 \mathrm{E}+12$ & $8.3217 \mathrm{E}-07$ & $8.3215 \mathrm{E}-07$ \\
\hline $\mathrm{Kr} 85$ & $3.3829 \mathrm{E}+08$ & $3.0853 \mathrm{E}-08$ & $2.2330 \mathrm{E}-08$ \\
\hline$R b 83$ & $7.4480 \mathrm{E}+06$ & $1.0612 \mathrm{E}-07$ & $4.4502 \mathrm{E}-14$ \\
\hline $\mathrm{Rb} 87$ & $1.5147 \mathrm{E}+18$ & $1.4318 \mathrm{E}-17$ & $1.4318 \mathrm{E}-17$ \\
\hline Sr 85 & $5.6022 \mathrm{E}+06$ & $1.9653 \mathrm{E}-09$ & $6.5286 \mathrm{E}-18$ \\
\hline
\end{tabular}




\begin{tabular}{|l|l|l|l|}
\hline Sr 89 & $4.3675 \mathrm{E}+06$ & $7.9752 \mathrm{E}-17$ & $1.0622 \mathrm{E}-27$ \\
\hline $\operatorname{Sr} 90$ & $8.8833 \mathrm{E}+08$ & $2.0545 \mathrm{E}-09$ & $1.8165 \mathrm{E}-09$ \\
\hline
\end{tabular}




\begin{tabular}{|c|c|c|c|}
\hline Nuclide & Halfife,s & 5 years & 10 years \\
\hline Y 88 & $9.2102 E+06$ & 1.4827E-05 & $1.0607 \mathrm{E}-10$ \\
\hline Y 90 & $2.3076 \mathrm{E}+05$ & $2.0550 \mathrm{E}-09$ & $1.8169 \mathrm{E}-09$ \\
\hline Y91 & $5.0553 \mathrm{E}+06$ & $3.7298 \mathrm{E}-15$ & $1.4991 \mathrm{E}-24$ \\
\hline $\mathrm{Zr} 88$ & $7.2058 \mathrm{E}+06$ & $1.1747 \mathrm{E}-07$ & $3.0073 \mathrm{E}-14$ \\
\hline Zr 93 & $4.8282 \mathrm{E}+13$ & $2.8134 \mathrm{E}-08$ & $2.8134 \mathrm{E}-08$ \\
\hline $\mathrm{Zr} 95$ & $5.5313 E+06$ & $1.0096 \mathrm{E}-12$ & $2.6112 \mathrm{E}-21$ \\
\hline $\mathrm{Nb} 91$ & $2.1459 \mathrm{E}+10$ & $8.6117 \mathrm{E}-04$ & $8.5680 \mathrm{E}-04$ \\
\hline $\mathrm{Nb} 91^{*}$ & $5.3568 \mathrm{E}+06$ & $2.2227 \mathrm{E}-12$ & $3.0190 \mathrm{E}-21$ \\
\hline $\mathrm{Nb} 92$ & $1.1045 \mathrm{E}+15$ & $1.9891 \mathrm{E}-08$ & $1.9891 \mathrm{E}-08$ \\
\hline $\mathrm{Nb} 93^{\circ}$ & $5.0901 \mathrm{E}+08$ & $1.1356 \mathrm{E}-02$ & $9.1640 \mathrm{E}-03$ \\
\hline $\mathrm{Nb} 94$ & $6.4061 \mathrm{E}+11$ & $1.8669 \mathrm{E}-05$ & $1.8666 \mathrm{E}-05$ \\
\hline Nb 95 & $3.0214 \mathrm{E}+06$ & $2.2249 \mathrm{E}-12$ & $5.6906 \mathrm{E}-21$ \\
\hline $\mathrm{Nb} 95^{*}$ & $3.1190 \mathrm{E}+05$ & $1.1876 \mathrm{E}-14$ & $3.0716 \mathrm{E}-23$ \\
\hline Mo 93 & $1.1045 \mathrm{E}+11$ & $2.1820 \mathrm{E}-05$ & $2.1798 E-05$ \\
\hline Tc 95* & $5.2700 \mathrm{E}+06$ & $2.8166 \mathrm{E}-17$ & $2.7330 \mathrm{E}-26$ \\
\hline Tc 97 & $8.2048 \mathrm{E}+13$ & $8.3894 \mathrm{E}-14$ & $8.3894 \mathrm{E}-14$ \\
\hline Tc $97^{*}$ & $7.8192 \mathrm{E}+06$ & $8.3148 \mathrm{E}-14$ & $7.0017 E-20$ \\
\hline Tc 98 & $1.3254 \mathrm{E}+14$ & $1.3930 \mathrm{E}-12$ & $1.3930 \mathrm{E}-12$ \\
\hline Tc 99 & $6.6617 \mathrm{E}+12$ & $2.4245 E-07$ & $2.4244 \mathrm{E}-07$ \\
\hline Rh102 & $9.1454 \mathrm{E}+07$ & $1.1117 \mathrm{E}-16$ & $3.3622 \mathrm{E}-17$ \\
\hline
\end{tabular}

Generation: Some steel shielding will be replaced annually. This waste will be generated by segregating the steel from the cavity vessel modules in order to reduce the amount of mixed or GTCC waste generated by the APT.

Handling and Packaging: Modules will be stored in the Target Pool for radioactive decay and residual tritium accumulation. After pool storage the modules will be placed in the Tritium Recovery Pit for tritium recovery. After tritium recovery the modules will be segregated and size reduced. The size reduced steel segments will be placed into disposal boxes in accordance with the waste acceptance criteria in the E-Area Vaults.

Annual Quantities:

\begin{tabular}{|c|c|r|r|}
\hline Target Design & Waste Destination & Volume & Mass \\
\hline LiAl & $\begin{array}{c}\text { On-site Disposal/ On-Site Storage/ } \\
\text { TBD }\end{array}$ & $1 \mathrm{~m}^{3}$ & $500 \mathrm{~kg}$ \\
\hline Helium-3 & $\begin{array}{c}\text { On-site Disposal/ On-Site Storage/ } \\
\text { TBD }\end{array}$ & $1 \mathrm{~m}^{3}$ & $500 \mathrm{~kg}$ \\
\hline
\end{tabular}

Waste Minimization:

(a) None identified at this time.

Treatment Options: 
(a) Package for LLRW disposal.

Comments: 


\section{B18. Aluminum}

Type: Low-level Radioactive Waste.

Description: Aluminum used for gas and cooling water headers and plenums. The aluminum will be on average $20 \%$ aluminum and $80 \%$ void space. They will have been exposed to the cavity vessel environment and will be activated with numerous spallation products.

\section{Aluminum Maximum Average Nuclides in $\mathrm{Ci} / \mathrm{CC}$ (time period is from beam shutdown)}

\begin{tabular}{|c|c|c|c|}
\hline Nuclide & Halflife,s & 2 years & 10 years \\
\hline $\mathrm{H} 3$ & $3.8910 \mathrm{E}+08$ & $1.1550 \mathrm{E}-01$ & $7.3665 \mathrm{E}-02$ \\
\hline $\mathrm{Be} 7$ & $4.6051 \mathrm{E}+06$ & 8.0447E-07 & $2.5261 \mathrm{E}-23$ \\
\hline $\mathrm{Be} 10$ & $5.0491 \mathrm{E}+13$ & $1.7741 \mathrm{E}-08$ & $1.7741 \mathrm{E}-08$ \\
\hline C 14 & $1.8082 \mathrm{E}+11$ & $5.1460 \mathrm{E}-06$ & $5.1411 \mathrm{E}-06$ \\
\hline $\mathrm{Na} 22$ & $8.2111 E+07$ & $1.3113 \mathrm{E}-01$ & $1.5565 \mathrm{E}-02$ \\
\hline Al 26 & $2.2721 \mathrm{E}+13$ & $8.8939 E-06$ & $8.8939 E-06$ \\
\hline Si 32 & $5.4279 \mathrm{E}+09$ & $7.8399 \mathrm{E}-13$ & $7.5912 \mathrm{E}-13$ \\
\hline $\mathrm{P} 32$ & $1.2321 \mathrm{E}+06$ & $7.8417 \mathrm{E}-13$ & $7.5929 \mathrm{E}-13$ \\
\hline 535 & $7.5600 \mathrm{E}+06$ & $2.6457 \mathrm{E}-14$ & $2.3435 \mathrm{E}-24$ \\
\hline $\mathrm{Cl} 36$ & $9.4986 \mathrm{E}+12$ & $1.0067 \mathrm{E}-17$ & $1.0067 \mathrm{E}-17$ \\
\hline Ar 39 & $8.4888 \mathrm{E}+09$ & $2.5907 \mathrm{E}-12$ & $2.5378 \mathrm{E}-12$ \\
\hline Ar 42 & $1.0382 E+09$ & $8.9009 E-15$ & $7.5202 \mathrm{E}-15$ \\
\hline K 40 & $4.0298 \mathrm{E}+16$ & $1.9388 \mathrm{E}-16$ & $1.9388 \mathrm{E}-16$ \\
\hline K 42 & $4.4496 \mathrm{E}+04$ & $8.9013 E-15$ & $7.5205 \mathrm{E}-15$ \\
\hline $\mathrm{Ca} \mathrm{41}$ & $3.2504 \mathrm{E}+12$ & $9.1409 E-08$ & $9.1404 E-08$ \\
\hline $\mathrm{Ca} 45$ & $1.4152 \mathrm{E}+07$ & $1.4637 \mathrm{E}-08$ & $6.2418 \mathrm{E}-14$ \\
\hline Sc 44 & $1.4137 E+04$ & $1.3633 \mathrm{E}-17$ & $1.2125 \mathrm{E}-17$ \\
\hline Sc 46 & $7.2412 \mathrm{E}+06$ & $2.6086 \mathrm{E}-07$ & $8.3397 E-18$ \\
\hline $\mathrm{Ti} 44$ & $1.4926 \mathrm{E}+09$ & $1.3633 E-17$ & $1.2125 \mathrm{E}-17$ \\
\hline V 49 & $2.9203 \mathrm{E}+07$ & $9.2187 \mathrm{E}-04$ & $2.3028 \mathrm{E}-06$ \\
\hline Cr SI & $2.3936 \mathrm{E}+06$ & $1.7406 \mathrm{E}-10$ & $.0000 \mathrm{E}+00$ \\
\hline $\mathrm{Mn} 53$ & $1.1802 \mathrm{E}+14$ & $2.6244 \mathrm{E}-17$ & $2.6244 \mathrm{E}-17$ \\
\hline $\mathrm{Mn} 54$ & $2.6967 \mathrm{E}+07$ & $1.8645 \mathrm{E}-07$ & $2.8338 \mathrm{E}-10$ \\
\hline Fe 55 & $8.6150 \mathrm{E}+07$ & $4.4226 \mathrm{E}-09$ & $5.8011 \mathrm{E}-10$ \\
\hline Fe 59 & $3.8445 \mathrm{E}+06$ & $2.5475 \mathrm{E}-12$ & $4.3457 \mathrm{E}-32$ \\
\hline $\mathrm{Fe} 60$ & $4.7335 \mathrm{E}+13$ & $7.6884 \mathrm{E}-14$ & $7.6884 \mathrm{E}-14$ \\
\hline Co 57 & $2.3484 \mathrm{E}+07$ & $6.5426 \mathrm{E}-10$ & $3.7982 \mathrm{E}-13$ \\
\hline Co 58 & $6.1271 \mathrm{E}+06$ & $1.5072 \mathrm{E}-10$ & $5.9503 \mathrm{E}-23$ \\
\hline Co 60 & $1.6635 \mathrm{E}+08$ & $8.2636 \mathrm{E}-05$ & $2.8861 \mathrm{E}-05$ \\
\hline Co 60* & $6.2820 \mathrm{E}+02$ & $7.6884 E-14$ & $7.6884 \mathrm{E}-14$ \\
\hline $\mathrm{Ni} 59$ & $2.3668 E+12$ & $1.1482 \mathrm{E}-07$ & $1.1482 \mathrm{E}-07$ \\
\hline $\mathrm{Ni} 63$ & $3.1588 \mathrm{E}+09$ & $7.6715 \mathrm{E}-05$ & $7.2581 \mathrm{E}-05$ \\
\hline $\mathrm{Zn} 65$ & $2.1073 \mathrm{E}+07$ & $7.9193 \mathrm{E}-06$ & $1.9600 \mathrm{E}-09$ \\
\hline Total & & $2.4773 \mathrm{E}-01$ & $8.9347 \mathrm{E}-02$ \\
\hline
\end{tabular}

Generation: Aluminum will be replaced annually. This waste will be generated by segregating the aluminum from the modules in order to reduce the amount of mixed or GTCC waste generated by the APT. 
Handling and Packaging: Modules will be stored in the Target Pool for radioactive decay and residual tritium accumulation. After target pool storage the modules will be placed in the Tritium Recovery Pit for tritium recovery . After tritium recovery the modules will be segregated and size reduced. The size reduced aluminum segments will be placed into disposal boxes in accordance with the waste acceptance criteria in the E-Area Vaults.

Annual Quantities:

\begin{tabular}{|c|c|r|r|}
\hline Target Design & Waste Destination & Volume & Mass \\
\hline LiAl & On-site Disposal/ On-Site Storage & $2 \mathrm{~m}^{3}$ & $1000 \mathrm{~kg}$ \\
\hline Helium-3 & On-site Disposal/ On-Site Storage & $2 \mathrm{~m}^{3}$ & $1000 \mathrm{~kg}$ \\
\hline
\end{tabular}

Waste Minimization:

(a) Compaction of this waste could reduce disposal volume.

Treatment Options:

(a) Package for LLRW disposal.

\section{Comments:}




\section{B19. Batteries}

Type: Mixed Low-level Waste, Low Level Radioactive Waste, Industrial, or Hazardous.

Description: Multiple types of batteries, such as nickel-cadmium, carbon-zinc, mercury, leadacid, and alkaline batteries. RCRA waste codes expected include D001, D002, D003, D006, D008, and D009.

Generation: Generated by spent batteries from radiation monitoring devices, other instrumentation, and backup power systems.

Handling and Packaging: Will vary depending on category of waste. None expected out of the ordinary.

Annual Quantities:

\begin{tabular}{|c|c|r|r|}
\hline Waste Category & Waste Destination & Volume & Mass \\
\hline Mixed & Off-site Disposal/On-Site Storage & $0.01 \mathrm{~m}^{3}$ & $2 \mathrm{~kg}$ \\
\hline LLRW & On-site Disposal & $0.01 \mathrm{~m}^{3}$ & $1 \mathrm{~kg}$ \\
\hline Hazardous & Off-Site Recycle/Disposal & $1 \mathrm{~m}^{3}$ & $500 \mathrm{~kg}$ \\
\hline Industrial & Industrial Landfill & $0.1 \mathrm{~m}^{3}$ & $50 \mathrm{~kg}$ \\
\hline
\end{tabular}

$\underline{\text { Waste Minimization: }}$

(a) Use non-hazardous batteries only in radiation areas.

Treatment Options:

(a) Various.

\section{Comments:}




\section{B20. APT Non-Radioactive Air Emissions}

\section{Type: Waste Gases}

Description: Gases discharged from APT processes via the one TSF 60 Meter stack, three Accelerator 60 meter stacks, one Target/Blanket 60 meter stack, and the numerous BOP stacks.

\section{ROUTINE APT NONRADIOLOGICAL AIR EMISSIONS}

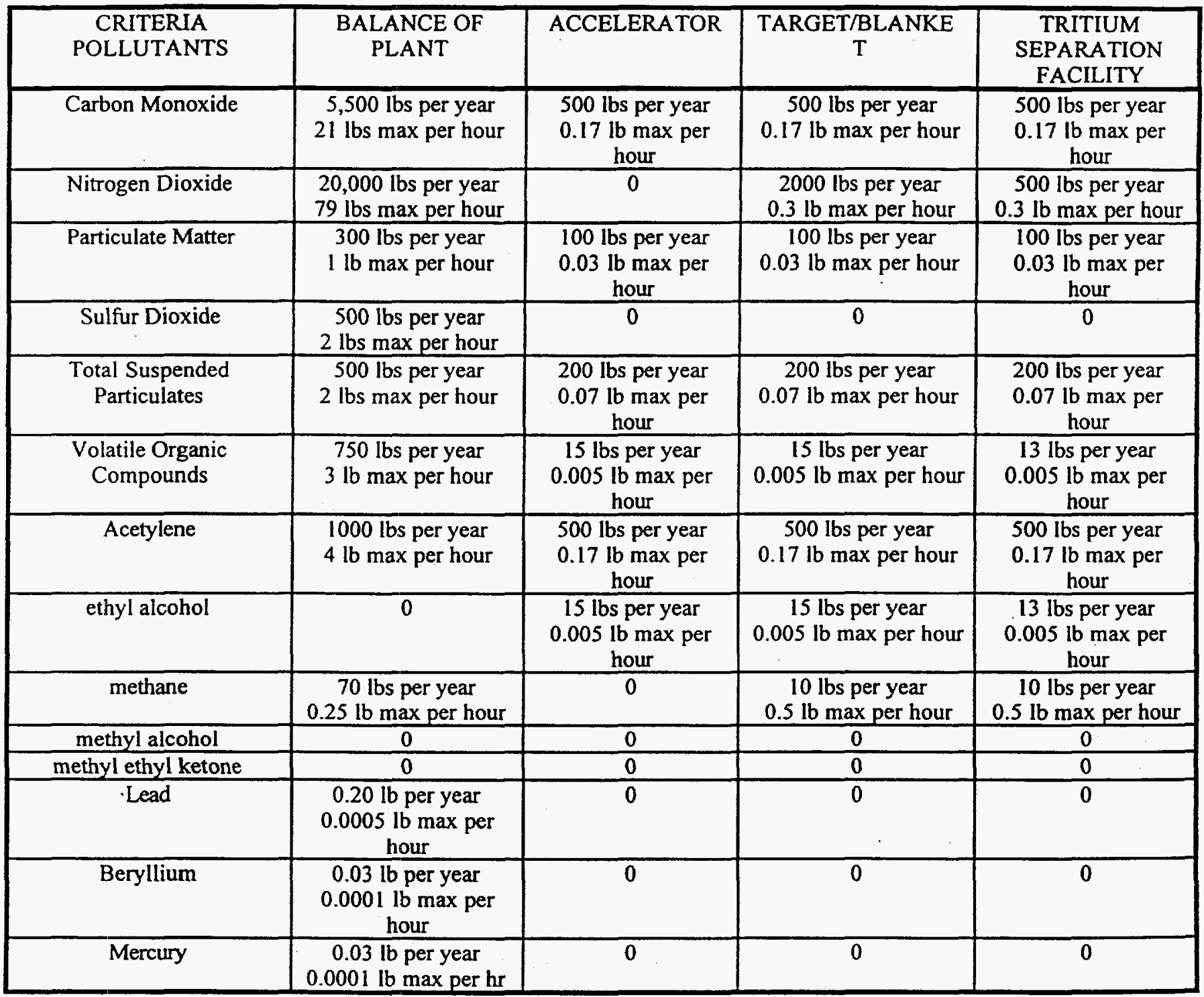

Generation: Routine APT operations. 
Handling and Packaging: Treated as required and discharged.

\section{Annual Quantities:}

\begin{tabular}{|c|c|}
\hline Waste Destination & Mass \\
\hline APT Stacks & $16,000 \mathrm{~kg}$ \\
\hline
\end{tabular}

Waste Minimization:

1. BOP diesel backup generators only operated at the minimum required to ensure operability.

2. Substitute cleaners without alcohol or VOCs.

\section{Treatment Options:}
(a) HEPA filtration
(b) Ion Exchange
(c) Carbon Filters
(d) Scrubbers

\section{Comments:}




\section{B21. APT Radioactive Air Emissions}

Type: Low-level Radioactive Waste

Description: Radioactive gases discharged from APT processes and facilities.

\section{Accelerator Radionuclide Releases During Normal Operations}

\begin{tabular}{|c|r|}
\hline Radionuclide & \multicolumn{1}{|c|}{$\mathrm{Ci} / \mathrm{Yr}$} \\
\hline $\mathrm{C}-10$ & 4.0 \\
\hline $\mathrm{C}-11$ & 233.0 \\
\hline $\mathrm{N}-13$ & 91.0 \\
\hline $\mathrm{N}-16$ & 1.0 \\
\hline $\mathrm{O}-14$ & 6.0 \\
\hline $\mathrm{O}-15$ & 118.0 \\
\hline $\mathrm{Ar}-41$ & 30.0 \\
\hline
\end{tabular}

Tritium Separation Facility Radionuclide Releases During Normal Operations

\begin{tabular}{|c|c|}
\hline Radionuclide & $\mathrm{Ci} / \mathrm{Yr}$ \\
\hline $\mathrm{H}-3$ & \\
\hline
\end{tabular}

\section{Target/Blanket Facility Radionuclide Releases During Normal Operations}

\begin{tabular}{|c|c|}
\hline Radionuclide & Ci/Yr \\
\hline Al-29 & $3.00 \mathrm{E}-06$ \\
\hline Ar-37 & $8.00 \mathrm{E}-02$ \\
\hline Ar-41 & $1.00 \mathrm{E}-03$ \\
\hline Be-7 & $2.00 \mathrm{E}-02$ \\
\hline Br-76 & $2.00 \mathrm{E}-05$ \\
\hline Br-77 & $3.00 \mathrm{E}-05$ \\
\hline $\mathrm{C}-11$ & $4.00 \mathrm{E}+01$ \\
\hline $\mathrm{Cl}-38$ & $2.00 \mathrm{E}-04$ \\
\hline $\mathrm{Cl}-39$ & $2.00 \mathrm{E}-05$ \\
\hline $\mathrm{Co}-55$ & $2.00 \mathrm{E}-07$ \\
\hline $\mathrm{Co}-56$ & $7.00 \mathrm{E}-07$ \\
\hline Co-57 & $2.00 \mathrm{E}-06$ \\
\hline Co-58 & $4.00 \mathrm{E}-06$ \\
\hline Co-58m & $3.00 \mathrm{E}-06$ \\
\hline
\end{tabular}




\begin{tabular}{|c|c|}
\hline Radionuclide & $\mathbf{C i} / \mathbf{Y r}$ \\
\hline $\mathrm{Cr}_{\mathrm{T}-5 \mathrm{I}}$ & $2.00 E-04$ \\
\hline $\mathrm{Cu}-62$ & $2.00 \mathrm{E}-07$ \\
\hline F-18 & $3.00 \mathrm{E}-02$ \\
\hline Fe-53 & $7.00 E-07$ \\
\hline Fe-55 & $1.00 \mathrm{E}-06$ \\
\hline Ga-68 & $2.00 \mathrm{E}-07$ \\
\hline $\mathrm{H}-3$ & $1.00 \mathrm{E}+04$ \\
\hline $1-123$ & $5.00 \mathrm{E}-05$ \\
\hline $1-124$ & $4.00 \mathrm{E}-05$ \\
\hline $1-125$ & $1.00 \mathrm{E}-03$ \\
\hline 1.126 & $6.00 \mathrm{E}-05$ \\
\hline $\mathrm{K}-38$ & $5.00 \mathrm{E}-07$ \\
\hline $\mathrm{K}-42$ & $5.00 \mathrm{E}-07$ \\
\hline $\mathrm{K}-43$ & $1.00 \mathrm{E}-07$ \\
\hline$\overline{K r-76}$ & $8.00 \mathrm{E}+00$ \\
\hline $\mathrm{Kr}-79$ & $1.00 \mathrm{E}-03$ \\
\hline $\mathrm{Mg}-27$ & $9.00 \mathrm{E}-07$ \\
\hline$\overline{M n-51}$ & $9.00 \mathrm{E}-07$ \\
\hline Mn-52 & $8.00 \mathrm{E}-07$ \\
\hline $\mathrm{Mn}-54$ & $1.00 \mathrm{E}-06$ \\
\hline $\mathrm{Mn}-56$ & $2.00 \mathrm{E}-06$ \\
\hline Mo-99 & $3.00 \mathrm{E}-07$ \\
\hline $\mathrm{N}-13$ & $2.00 \mathrm{E}+0 \mathrm{l}$ \\
\hline $\mathrm{Na}-22$ & $2.00 \mathrm{E}-07$ \\
\hline $\mathrm{Na}-24$ & $8.00 \mathrm{E}-07$ \\
\hline $\mathrm{Ni}-57$ & $6.00 E-07$ \\
\hline P-32 & $4.00 \mathrm{E}-07$ \\
\hline $\mathrm{P}-33$ & $1.00 \mathrm{E}-07$ \\
\hline $\mathrm{Sc}-43$ & $4.00 \mathrm{E}-07$ \\
\hline $\mathrm{Sc}-44$ & $5.00 \mathrm{E}-06$ \\
\hline Sc-46 & $2.00 \mathrm{E}-07$ \\
\hline $\mathrm{Sc}-47$ & $3.00 \mathrm{E}-07$ \\
\hline Sc-49 & $1.00 \mathrm{E}-07$ \\
\hline$\overline{S i-3 i}$ & $1.00 \mathrm{E}-06$ \\
\hline Tc-99m & $2.00 \mathrm{E}-07$ \\
\hline $\mathrm{Ti}-45$ & $1.00 \mathrm{E}-06$ \\
\hline V-47 & $1.00 \mathrm{E}-06$ \\
\hline V-48 & $7.00 \mathrm{E}-07$ \\
\hline V-49 & $6.00 E-07$ \\
\hline W-187 & $3.00 E-07$ \\
\hline Xe-122. & $1.00 \mathrm{E}-03$ \\
\hline $\mathrm{Xe}-125$ & $3.00 \mathrm{E}-03$ \\
\hline $\mathrm{Xe}-127$ & $5.00 \mathrm{E}-02$ \\
\hline
\end{tabular}


Generation: Routine APT operations.

Handling and Packaging: Delay system for radioactive decay, treated as required, monitored as needed, and discharged.

\section{Annual Quantities: N/A}

Waste Minimization:

1. The T/B cavity vessel is operated in a vacuum to minimize the activation of air.

2. The accelerator is closed to air movement during beam operations and not opened until the short lived activation products have disappeared.

3. Delay systems will be installed into APT air movement and stacks to decay short-lived isotopes before release.

Treatment Options:
(a) HEPA filtration
(b) Ion Exchange
(c) Carbon Filters
(d) Delay systems
(e) Condensation
(f) Scrubbers

\section{Comments:}




\section{B22. Job Control Waste ( LiAl Extraction)}

Type: Low-level Radioactive Waste, Intermediate-level Waste

\section{Description: See Waste Stream B1.}

Generation: Job Control Waste (LiAl Extraction) is generated during production, maintenance, decontamination or housekeeping activities in the LiAl extraction areas. Job Control Waste (LiAl Extraction) is collected from all processing areas exposed to LiAl material in the extraction area. Tritium is likely also to be present. All contaminants should exist as removable surface contamination.

\section{Handling and Packaging: See Waste Stream B1.}

Annual Quantities:

\begin{tabular}{|c|r|r|}
\hline Waste Destination* & Volume & Mass \\
\hline CIF & $150 \mathrm{~m}^{3}$ & $20,000 \mathrm{~kg}$ \\
\hline Compaction/LAW Vaults & $75 \mathrm{~m}^{3}$ & $10,000 \mathrm{~kg}$ \\
\hline Direct to LAW Vaults & $75 \mathrm{~m}^{3}$ & $10,000 \mathrm{~kg}$ \\
\hline
\end{tabular}

*Intermediate-level waste would go to ILTV Bulk Cell instead of LAW Vaults.

(a) Assume baseline of $21,000 \mathrm{ft}^{3}$ per year for 14 extractions and RTF per Table B1.

(b) Per current practice, assume 2/3 for APT Extraction/Purification $=>14,000 \mathrm{ft}^{3}$.

(c) Assume $\mathrm{x} 3$ for 42 extractions/year in APT $=>42,000 \mathrm{ft}^{3}$.

(d) Assume $\times 1 / 2$ for improved waste minimization practices in gloveboxes $=>21,000 \mathrm{ft}^{3}$.

(e) Assume 1/2 for APT Extraction areas $=>10,500 \mathrm{ft}^{3}$.

(f) Assume $50 \%$ to CIF, $25 \%$ to Compaction/LAW Vaults, $25 \%$ directly to LAW Vaults,

(g) Assume compaction $4 \mathrm{x}$ volume reduction $=>656 \mathrm{ft}^{3}$ compacted waste to LAW Vaults.

Waste Minimization: $\quad$ See Waste Stream B1.

\section{Treatment Options:}

(a) Incineration at CIF, followed by cement stabilization of ash/residue. Disposal of stabilized ash in the E-Area Vaults if passes TCLP; storage as mixed waste for further treatment if waste fails TCLP.

(b) Compaction for disposal in the EAV LAW Vaults.

Comments: 
(a) In a 1992 PWA, absorbent wipes made up $1 \%$ of a total waste of $25,457 \mathrm{ft}^{3}\left(721 \mathrm{~m}^{3}\right)$ at the SRS tritium processing facility (Ref: WSRC, "1992 Process Waste Assessment, Tritium Facility Low-level Waste," NMP-STE-93138, 8/13/93). Waste stream characteristics were estimated on the basis of purchasing records, observation of sample waste-handling activities, and interviews with operations personnel.

(b) It will be necessary to assay this waste stream for beta-gamma contamination due to the presence of activated $\mathrm{LiAl}$ material. 


\section{B23. Spent LiAl Extraction}

Type: Intermediate-level Waste.

Description: Melted lithium aluminum target material with $99.9 \%$ of the tritium has been extracted. The melted material is contained in the stainless steel crucibles used for extraction; the crucibles and the contained melt are disposed as a single unit. Both the melt and crucibles are contaminated with tritium and activation products.

Generation: Crucibles are placed in a furnace to extract tritium. During furnace extraction, the released tritium gas is pumped from the enclosed furnace for subsequent purification. Some volatile metals such as $\mathrm{Zn}-65$ from the irradiated $\mathrm{LiAl}$ will also be vaporized during extraction. After extraction, the spent LiAl contain only residual amounts of tritium. Most of the other radionuclides in the spent $\mathrm{LiAl}$ are expected to remain in the metal matrix. The LiAl target design will generate approximately 25 crucibles per year.

Handling and Packaging: Waste must be surveyed for gamma radiation field and packaged to meet the handling requirements of the waste disposal facility. A shipping cask and overpack will need to be developed for transporting spent crucibles to Waste Management. The cask may be re-used if the crucible can meet WAC 3.10 for the EAV.

Annual Quantities:

\begin{tabular}{|c|r|r|}
\hline Waste Destination & Volume & Mass \\
\hline ILTV Silos (LiAl) & $14 \mathrm{~m}^{3}$ & $22,000 \mathrm{~kg}$ \\
\hline ILTV Silos (Crucibles) & $6 \mathrm{~m}^{3}$ & $14,500 \mathrm{~kg}$ \\
\hline
\end{tabular}

Waste Minimization:

(a) Process optimization to increase yield of tritium per weight of $\mathrm{LiAl}$ target material.

(b) Use Crucibles twice before discarding.

\section{Treatment Options:}

None required.

Comments:

(a) In the past, hollow $\mathrm{LiAl}$ pieces in open crucibles would reduce in volume in the furnace and the crucibles were used twice before being discarded. 


\section{B23. Spent LiAl Extraction}

Type: Intermediate-level Waste.

Description: Melted lithium aluminum target material with $99.9 \%$ of the tritium has been extracted. The melted material is contained in the stainless steel crucibles used for extraction; the crucibles and the contained melt are disposed as a single unit. Both the melt and crucibles are contaminated with tritium and activation products.

Generation: Crucibles are placed in a furnace to extract tritium. During furnace extraction, the released tritium gas is pumped from the enclosed furnace for subsequent purification. Some volatile metals such as $\mathrm{Zn}-65$ from the irradiated $\mathrm{LiAl}$ will also be vaporized during extraction. After extraction, the spent LiAl contain only residual amounts of tritium. Most of the other radionuclides in the spent $\mathrm{LiAl}$ are expected to remain in the metal matrix. The LiAl target design will generate approximately 25 crucibles per year.

Handling and Packaging: Waste must be surveyed for gamma radiation field and packaged to meet the handling requirements of the waste disposal facility. A shipping cask and overpack will need to be developed for transporting spent crucibles to Waste Management. The cask may be re-used if the crucible can meet WAC 3.10 for the EAV.

\section{Annual Quantities:}

\begin{tabular}{|c|r|r|}
\hline Waste Destination & Volume & Mass \\
\hline ILTV Silos (LiAl) & $14 \mathrm{~m}^{3}$ & $22,000 \mathrm{~kg}$ \\
\hline ILTV Silos (Crucibles) & $6 \mathrm{~m}^{3}$ & $14,500 \mathrm{~kg}$ \\
\hline
\end{tabular}

Waste Minimization:

(a) Process optimization to increase yield of tritium per weight of LiAl target material.

(b) Use Crucibles twice before discarding.

Treatment Options:

None required.

\section{Comments:}

(a) In the past, hollow LiAl pieces in open crucibles would reduce in volume in the furnace and the crucibles were used twice before being discarded. 


\section{B24. Nonhazardous Process Equipment (LiAl Extraction)}

Type: Intermediate-level Waste, Low-level Radioactive Waste

Description: This waste stream consists of discarded process equipment or parts. Equipment may include vessels, tanks, pressure gauges, valves and fittings which provided primary tritium containment, as well as pneumatic cutters, video cameras, cranes and confinement box parts. Minor maintenance parts (e.g., small gaskets, bolts) are managed as Job Control Waste. All process equipment is considered to be non-incinerable and non-compactible due to physical form and potential tritium offgassing.

Generation: Nonhazardous Process Equipment (LiAl Extraction) waste is generated by preventative and corrective maintenance of the tritium furnace extraction systems, or by replacement of containment devices in the extraction process. Due to the potential for highly radioactive gamma emitters, some waste may be too hot to be disposed of in the LAW vaults.

Handling and Packaging: Following removal from process, process equipment may be stored in engineered hoods to control offgassing tritium within monitored ventilation system. Management will review tritium offgassing rate, radiation emission and facility conditions to determine when to dispose of process equipment. Equipment pieces are wrapped in plastic bags (heavy duty polyurethane). Following a period of off-gassing and/or decay, the plastic-wrapped equipment will be placed into pre-approved containers (B-12, B-25, 55 gallon drums, 5 gallon containers, etc.) for transport to the E-Area Vaults.

\section{Annual Quantities:}

\begin{tabular}{|c|r|r|}
\hline Waste Destination & Volume & Mass \\
\hline LAW Vaults & $2.5 \mathrm{~m}^{3}$ & $3,400 \mathrm{~kg}$ \\
\hline ILTV Bulk Cell & $2.5 \mathrm{~m}^{3}$ & $3,400 \mathrm{~kg}$ \\
\hline
\end{tabular}

(a) Assume two B-12 containers per year to LAW Vaults $\Rightarrow 2.5 \mathrm{~m}^{3}$.

(b) Assume two B-12 containers per year to ILTV Bulk Cell $=>2.5 \mathrm{~m}^{3}$

(c) Assume $75 \%$ void space, 50 vol \% aluminum ( $2.7 \mathrm{SpG}$ ), 50 vol \% stainless steel $(8.0$ $\mathrm{SpG})=>90 \times 0.25 \times 62.3 \times(0.5 \times 2.7+0.5 \times 8) \sim 7,430 \mathrm{lb}$.

Waste Minimization:

(a) Extend process equipment life through reliability centered maintenance.

(b) Decontaminate equipment and recycle metal.

Treatment Options:

Store until acceptable decay rates are achieved. 


\section{Comments:}

Radioactive contaminants will have the same distributions as spent LiAl and crud. 


\section{B24a. Failed Furnace Components (LiAl Extraction)}

Type: Intermediate-level Waste.

Description: Furnace cover, heaters and gaskets.

Generation: Furnace heaters will burn out. Baskets and furnace covers may experience structural failure. Furnace cover gaskets are replaced for each furnace charge.

Handling and Packaging: Waste must be surveyed for radiation and packaged to meet the handling requirements of the EAV Intermediate Level Tritium Vaults. A shipping cask will need to be developed for transporting failed components to Solid Waste Management.

Annual Quantities:

\begin{tabular}{|c|r|r|}
\hline Waste Destination & Volume & Mass \\
\hline ILTV Bulk Cell & $2.5 \mathrm{~m}^{3}$ & $3,400 \mathrm{~kg}$ \\
\hline
\end{tabular}

(a) Assume two B-12 containers per year to ILTV Bulk Cell $\Rightarrow 2.5 \mathrm{~m}^{3}$

(b) Assume $75 \%$ void space, 50 vol \% aluminum (2.7 SpG), 50 vol \% stainless steel (8.0 $\mathrm{SpG})=>90 \times 0.25 \times 62.3 \times(0.5 \times 2.7+0.5 \times 8) \sim 7,430 \mathrm{lb}$.

Waste Minimization:

There is no feasible alternative to the use of electrically heated furnaces.

Treatment Options:

Volume reduction, followed by packaging for disposal in EAV Intermediate Level Vaults.

Comment:

None. 


\section{B24b. HEPA Filters (LiAl Extraction)}

Type: Low-level Radioactive Waste or Intermediate-level Waste.

Description: High-efficiency particulate air (HEPA) filters are filters capable of trapping and retaining at least 99.97 percent of all monodispersed particles $\geq 0.3 \mu \mathrm{m}$ in diameter. HEPA filters are generally made of a variety of paper and metallic materials.

Generation: Extraction furnace gases and stack gases are passed through HEPA filters, and the filters require regular replacement.

Annual Quantities:

\begin{tabular}{|c|c|c|}
\hline Waste Destination & Volume & Mass \\
\hline HEPAs to LAW Vaults & $0.28 \mathrm{~m}^{3}$ & $55 \mathrm{~kg}$ \\
\hline
\end{tabular}

Waste Minimization:

A reusable HEPA filter is being developed.

Treatment Options:

Not applicable if reusable filters are used. Treatment for a conventional HEPA filter is a function of its composition; i.e., whether it is largely paper (thermal treatment) or metal (compaction). Since APT HEPA filters are assumed to be constructed of nonhazardous materials, they will be characterized and packaged for disposal, as appropriate.

Comments:

(a) HEPA filters will not prevent the release of tritium to the atmosphere. However, HEPA filters may be used to remove particulates which may contain tritium contamination.

(b) Carbon filters may be used in conjunction with HEPA filters to remove organics from stack gases. However, this would introduce an additional waste of spent carbon beds. 
[This Page Left Intentionally Blank] 


\section{APPENDIX C}

\section{Treatment and Disposal of APT Waste}

The major sources of APT waste are personal protection equipment (PPE) job control waste (JCW) from routine maintenance, the Target/Blanket modules removed from service, accelerator maintenance and Tritium Separation Facility wastes. The primary treatment for the JCW is incineration at the SRS Consolidated Incineration Facility (CIF) followed by cement stabilization of the ash residue or compaction followed by disposal in the SRS E-Area Vaults. The primary treatment for T/B modules is segregation and macroencapsulation followed by disposal in the $\mathrm{E}$ Area Vaults or off-site. The possibility of melting and recycling stainless steel with slight tritium contamination should also be considered.

Appendix $\mathrm{C}$ describes the treatment and disposal options for APT waste, evaluates relevant existing and planned treatment facilities at SRS and other DOE sites, and describes relevant waste treatment technologies for APT waste. This discussion is organized into the following sections:

C1. APT Waste Disposition

C1.1 Low-Level Radioactive Waste

C1.2 Mixed Low-Level Waste

C1.3 Hazardous Waste

C2. Existing and Planned SRS Waste Treatment, Storage and Disposal Facilities

C2.1 E-Area Vaults

C2.2 Consolidated Incineration Facility

C2.3 Hazardous/Mixed Waste Storage Pads/Buildings

C2.4 Sanitary Landfill

C2.5 Sanitary Sewerage Treatment Facility

C2.6 Hazardous Waste/Mixed Waste Disposal Facility

C2.7 Prohibited Wastes

C3. Other DOE and Commercial Waste Treatment Facilities

C3.1 Hanford

C3.2 Nevada Test Site

C3.3 SEG

C3.4 DSSI

C3.5 Envirocare

C3.6 GTS Duratek 
C4. Treatment Technologies

C4.1 Compaction

C4.2 Thermal Desorption

C4.3 Incineration

C4.4 Stabilization

C4.5 Vitrification

C4.6 Encapsulation

C4.7 Metals Recovery 


\section{C1. APT Waste Disposition}

The APT wastes will be managed for treatment and disposal according to waste type. SRS and off-site or vendor-operated waste treatment, storage and disposal (TSD) facilities that may be used to treat, store or dispose of APT waste are shown in Fig. C-1. The APT-relevant TSD facilities are presented in plain shaded boxes. The shaded and shadowed boxes denote APT waste TSD facilities either off-site or at SRS but operated by vendors (Envirocare, GTS Duratek, Compaction and the Sanitary Landfill at SRS being developed by the Three River Solid Waste Authority).

Non-APT off-site and SRS waste streams and TSD facilities are shown in Fig. C-1 for information only and for completeness. These wastes and facilities include: TRU Waste, HighLevel Waste, In-Tank Precipitation (ITP)/Late Wash, Defense Waste Processing Facility (DWPF), Saltstone, TRU Storage Pads, DWPF Storage Building, Saltstone Vaults, and the Burial Grounds, previously used for low-level radioactive waste (LLRW) disposal, now replaced by the E-Area Vaults. The off-site waste facility of interest for APT generated Greater Than Class C (GTCC) LLRW and MLLW are Yucca Mountain repository and Nevada Test Site.

\section{C1.1 Low-Level Radioactive Waste}

The vast majority of radioactive waste generated by the APT is expected to be low-level radioactive waste. APT LLRW is expected to consist of both highly radioactive remote-handled waste from the Target/Blanket Cavity Vessel, contact handled waste from the T/B Facility, remote handled and contact handled accelerator wastes, and tritium processing contact-handled waste. Remote-handled LLRW includes T/B modules and some accelerator components. Maintenance waste, discarded particulate filters and failed equipment from separation are also expected to be remote-handled. The high radiation levels originate in the activated and spallation regions of the APT. Characterization of LLRW and MLLW is contained in Appendix B. Contact handled waste consists mostly of job control waste (shoe covers, plastic sheeting, gloves, plastic suits, kraft paper, absorbent wipes, etc.) from process operations and analytical waste with activated materials, spallation product and trace tritium contamination, as well as more highly contaminated process equipment waste (piping, valves and fittings, gauges, pumps, metal hydride beds, catalyst beds, and zeolite beds). Routine process waste should be spent magnesium or uranium beds, window modules, segregated aluminum and steel from $\mathrm{T} / \mathrm{B}$ modules, and primary coolant discharge.

Some containerized SRS LLRW are projected to be disposed of in the E-Area Vaults (EAV). The E-Area Vaults are divided into Low-Activity Waste (LAW) Vaults, Intermediate Level Tritium Vaults (ILTV), and Intermediate Level Non-Tritium Vaults (ILNTV). LLRW with 
tritium content of less than $1000 \mathrm{Ci}$ and minimal tritium off-gassing (less than $4 \mathrm{E}-5 \mu \mathrm{Ci} / \mathrm{cc}$ ) may be disposed of in B-25 containers in the LAW vaults. The LLRW spent target waste from LiAl extraction is proposed to be disposed of in the ILTV tritium silos originally designed for current SRS extraction crucible waste. These silos have a current disposal limit of 40,000 curies of tritium per container. The ILTV also have a bulk cell for disposal of tritiated waste containing more than 1000 curies of tritium per container.

The APT LLRW designated for the E-Area Vaults disposal must meet WAC 3.10 of the WSRC 1S Manual. If characterization of the APT waste should indicate that the EAV WAC 3.10 cannot be met, either 1) an exemption would have to be granted, 2) the WAC limits would have to be revised, 3) a new waste disposal facility would have to be built to accommodate this waste, or 4) disposal off-site. Development of a new WAC for the APT waste will require conducting a Radiological Performance Assessment to determine long term waste disposal impact on the groundwater and post-institutional control intruders.

APT generated Greater Than Class C (GTCC) LLRW will require disposal at a TBD facility.

The low-activity job control waste may also be segregated for either off-site or on-site compaction, or incineration at the Consolidated Incineration Facility (CIF), prior to disposal in the EAV. Incinerable APT waste going to the CIF must meet the CIF waste acceptance criteria (WAC 3.13 in WSRC 1S Manual). On-site waste compaction using the existing compactor in Building 253-H must meet WAC 3.11 .

\section{C1.2 Mixed Low-Level Waste}

Incinerable APT mixed low-level waste with low radioactive contamination and trace amounts of RCRA metals will be treated in the CIF. Non-incinerable wastes such as the lead modules will be macroencapsulated under the Debris Rule at the APT.

There is currently no APT mixed waste requiring vitrification but GTS Duratek is a potential vendor for vitrifying mixed waste in the future; it currently has a contract to vitrify SRS M-Area mixed waste sludges.

Hanford and NTS are currently authorized to dispose only their treated MLLW on site, however, some shipments of MLLW to Hanford for disposal have been allowed by DOE on a case-by-case basis. These shipments have been primarily either mixed waste containers whose surface dose rate exceeded $200 \mathrm{mrem} / \mathrm{hr}$ and therefore required remote handling, "special waste", defined as waste that requires special handling, or unique waste, such as decommissioned reactor vessels. Savannah River had a planned MLLW disposal facility. However, this project has been placed on indefinite hold and DOE is revising its strategy for mixed waste disposal. 


\section{C1.3 Hazardous Waste}

Incinerable APT hazardous waste meeting the CIF WAC 3.13 will be incinerated in the CIF. Per current practice, other APT hazardous waste can be disposed of at any number of DOE or SRSapproved commercial facilities.

\section{C2. Existing and Planned SRS Waste Treatment, Storage and Disposal Facilities}

\section{C2.1 E-Area Vaults (EAV)}

The E-Area Vaults at SRS are designed to dispose of low-level and intermediate level radioactive waste. Intermediate-level waste is a subset of low-level waste. The term is used to designate low-level waste having high levels of gamma activity and may require non-contact handling.

As stated in C1.1, the E-Area Vaults are divided into the Low-Activity Waste (LAW) Vaults, the Intermediate Level Tritium Vaults (ILTV), which include a Bulk Cell and Tritium Silos, and the Intermediate Level Non-Tritium Vaults (ILNTV). Within the boundary of the EAV is a storage building for long-lived radioisotope waste such as reactor ion exchange resin containing C-14 and areas set aside for shallow land or trench burial of containerized Naval Reactor waste components and other cemented waste forms.

LLRW with tritium content of less than $1000 \mathrm{Ci}$ and minimal tritium off-gassing (less than $4 \mathrm{E}-5$ $\mu \mathrm{Ci} / \mathrm{cc}$ ) may be disposed of in B-25 and other approved containers in the LAW Vaults. The LAW Vaults building in operation is approximately $200 \mathrm{~m} \times 44 \mathrm{~m} \times 8.2 \mathrm{~m}$ and is divided into 12 cells. The concrete end and side walls are 24" thick. The concrete interior walls and base slab are 12" thick. The LAW Vaults building has storage capacity for 12,000 B-25 containers, stacked 4 high. The original plans were to construct 21 vaults of this design. Due to successful waste minimization efforts at SRS and cost considerations, the number of vaults will likely be scaled back.

The Intermediate Level Vaults are subsurface concrete structures designed to handle and dispose of non-contact waste. Two of the seven ILV cells are designed specifically to handle tritium waste: a bulk cell and a cell containing 140 silos designed to accept tritium extraction crucible waste. The ILV base slab, side and end walls are constructed of 30 " concrete. The interior walls are 20 " concrete. The ILTV bulk cell is approximately $15.2 \mathrm{~m}$ by $7.6 \mathrm{~m}$ by $8.8 \mathrm{~m}$ in height. It is used for disposal of tritiated waste which contains more than 1000 curies of tritium per container, usually waste equipment such as zeolite beds and diffusers. The tritium silos are approximately 6 meters deep and tapered from 30" to 20" in diameter at the bottom (SRS Drawing W2020320). Top shielding for the silos are provided by 40 " thick concrete plugs. The ILTV silos have a 
current disposal limit of 40,000 curies of tritium each. Classified tritium waste is also disposed of in the ILTV.

The E-Area Vaults are operated by the Solid Waste Division. The governing WAC is WAC 3.10 of the 1S Manual.

\section{C2.2 Consolidated Incineration Facility (CIF)}

The Consolidated Incineration Facility, located between S-Area and H-Area at the SRS, is designed to incinerate both solid and liquid wastes from several generators around the SRS. Liquid waste can be sent by container or pipeline. Solid waste for incineration should be packaged in standard 21 "x 21 "x 21 " cardboard boxes.

The CIF is a rotary kiln incinerator with a secondary combustion chamber. The liquid waste is fed into both the rotary kiln's primary combustion chamber and the secondary combustion chamber. Solid waste is fed into the primary combustion chamber. Organic materials are combusted to water and carbon dioxide. Off-gas is quenched, scrubbed in a caustic solution and discharged to the atmosphere.

Non-combustible ash materials are collected, mixed with Portland cement and other stabilizing additives, and cast into stable solid waste forms referred to as "ashcrete". The ashcrete system also stabilizes blowdown liquid from the quench and scrubber ("blowcrete"). The ashcrete system could also be used to encapsulate other small waste components that could be mixed directly with the ash. It is also possible some of the discharged APT tritium contaminated light water primary coolant can be solidified in this system.

The estimated CIF thermal capacity of 18 million BTU/hr is based on the design estimate of wastes expected to be in inventory at the time of CIF start-up and on wastes expected to be generated annually after CIF start-up. To maximize the flexibility and utilization of the CIF, the material handling systems for feeding solid and liquid wastes were sized for a greater throughput than the average annual requirement for each system. The instantaneous capacity of the individual sub-systems are as follows:

- Solid waste to rotary kiln

- Organic liquid waste to rotary kiln

- Aqueous liquid waste to rotary kiln

- Organic liquid waste to secondary combustion chamber
$2025 \mathrm{lbs} / \mathrm{hr}$

$385 \mathrm{lbs} / \mathrm{hr}$

$950 \mathrm{lbs} / \mathrm{hr}$

$302 \mathrm{lbs} / \mathrm{hr}$

The CIF can generally treat any combination of liquids and solids up to the rates listed above, provided that the thermal capacity and other operational limits are not exceeded. The CIF is expected to have excess capacity for treating other SRS and non-SRS DOE incinerable wastes. 
The schedule for treating other wastes at CIF will be established based on several key factors, including:

- Available thermal capacity

- Concentrations of waste constituents (e.g., hazardous metals) controlled by the warious CIF environmental permits.

- Concentrations of waste constituents (e.g., chlorides and non-combustibles) directly influencing the amount of bottom ash and off-gas scrubber blowdown generated. When wastes generating significant ash or blowdown are incinerated, the demand on the spare ashcrete unit capacity could become the factor limiting waste feed rates.

The nominal capacities for CIF are $100,000 \mathrm{~m}^{3} / \mathrm{yr}$ of solid waste feed and $340 \mathrm{~m}^{3} / \mathrm{yr}$ of liquid waste feed.

The CIF is operated by the Solid Waste Division. The governing WAC is WAC 3.13 in the SRS IS Manual.

\section{C2.3 Hazardous/Mixed Waste Storage Pads/Buildings}

The APT hazardous and mixed waste not going directly to an off-site vendor for treatment or offsite disposal may be stored in a number of storage pads or buildings. Current mixed waste storage facilities include Mixed Waste Storage Buildings 643-29E and 643-43E in E-Area, 645$2 \mathrm{~N}$ near the Central Shops, and $315-4 \mathrm{M}$ and 316-M in M-Area. Mixed waste storage pads are located in the Solid Waste Disposal Facility. Hazardous waste is currently stored at the SRS Waste Management Hazardous Waste Storage Facility. This facility includes Building 645-N and $645-4 \mathrm{~N}$ near the Central Shops, Building 710-B in B-Area and Solid Waste Storage Pads 1, 2 and 3.

It is anticipated the high radiation (approximately $6400 \mathrm{R}+$ at 3 inches - unshielded) MLLW generated by the APT will require additional storage space.

Hazardous and mixed waste management is the responsibility of the Solid Waste Division. The governing WACs in the WSRC 1S Manual are WAC 3.07 for mixed waste storage and WAC 3.08 for hazardous waste storage.

\section{C2.4 Sanitary Landfill}

The APT solid sanitary waste is expected to go to a sanitary landfill located on the SRS. The Three River Solid Waste Authority is developing an 1100-acre site on the SRS for a regional 
landfill. It is anticipated to be in operation prior to the start-up of APT operations. It will provide capacity for receiving sanitary waste from an 8-county area around SRS. It will also provide for demonstrating state-of-the art treatment technologies for solid waste. The landfill should be a subtitle D landfill with double liners and a leachate collection system.

Sanitary waste management is the responsibility of the Solid Waste Division. The governing WAC is WAC 3.09 in the SRS IS Manual.

\section{C2.5 Sanitary Sewage Treatment Facility}

Sanitary sewage at SRS is treated at a centralized facility near F-Area and at a number of local facilities. APT sewage will be piped and pumped to the central sanitary facility constructed in 1995. Sewage is processed using an oxidation ditch, an intra-channel clarifier, chlorination, settling ponds, and ultraviolet disinfection. The sewage treatment facility has a capacity for processing 1.05 million gallons per day.

The sanitary sewage treatment facilities are operated by Site Services Division. There is no WAC for this facility.

\section{C2.6 Hazardous Waste/Mixed Waste Disposal Facility (HW/MW DF)}

The Hazardous Waste/Mixed Waste Disposal Facility (HW/MW DF) at SRS was a line-item project whose status is uncertain at this point. A project rescoping that will impact cost and schedule was submitted to DOE and no action has been taken. NEPA documentation was prepared for the HW/MW DF. A decision by DOE as to whether an Environmental Assessment or Environmental Impact Statement will be required is also pending. Until the NEPA and project scope questions have been answered, schedule and milestones cannot be defined. It is likely this project will be canceled.

\section{C2.7 Prohibited Wastes}

The waste destined for a particular treatment, storage or disposal facility at SRS must, in general, meet the Waste Acceptance Criteria of that facility. Exemptions or deviations may be granted in the case of noncompliance. For general guidance, Savannah River Site waste treatment, storage and disposal facilities will not accept the following for disposal, without special approval:

- Aerosol cans (pressurized, non-empty)

- Compressed gas cylinders

- Biologic, pathogenic or infectious materials

- Waste that can detonate or explode

- Waste that can generate toxic fumes or gases 
- Incompatibles wastes in the same container

- Pyrophorics

- Shock sensitive waste

- Waste containing cyanide or sulfides not chemically bound

- Wastes that are only corrosive (D002) must be neutralized prior to disposal

- Uncontainerized waste

- Wastes containing polychlorinated biphenyls $\geq 50 \mathrm{ppm}$ (TSCA waste)

- Unidentified, uncharacterized, or poorly characterized waste.

In addition, non-hazardous waste should not be sent to the hazardous waste facility and sanitary waste should not be sent to the EAV.

For definitive guidance, the reader should refer to the complete set of Waste Acceptance Criteria for the specific waste treatment, storage and disposal facility of interest.

\section{C3. Other DOE and Commercial Waste Treatment Facilities}

In addition to SRS, several other DOE sites are capable of treating and/or disposing of low-level and mixed low-level waste. Several commercial vendors have also been approved for treating low-level and mixed low-level wastes.

Relevant treatment facilities for APT waste at SRS, INEL, Oak Ridge, Pantex, and Hanford are summarized in Table C1. The Nevada Test Site (NTS) is a potential disposal site for low-level waste and MLLW, but has no on-site treatment facilities. Only those facilities that have at least passed DOE KD-0, Approval of Mission Need, are listed. Typically at this stage, conceptual design and the preparation of NEPA documentation have been initiated. 
Table C1

\section{Existing and Planned DOE Waste Treatment Facilities Relevant for APT Waste}

\begin{tabular}{|c|c|c|c|c|c|}
\hline Site & Facility & Treatment(s) & $\begin{array}{c}\text { Allowable } \\
\text { Waste }\end{array}$ & $\begin{array}{c}\text { Design } \\
\text { Capacity } \\
\mathrm{m}^{3} / \mathrm{yr} \\
\end{array}$ & $\begin{array}{c}\text { Estimated } \\
\text { Start-up Date }\end{array}$ \\
\hline \multirow[t]{4}{*}{$\overline{\text { SRS }}$} & $\begin{array}{l}\text { Consolidated } \\
\text { Incineration Facility } \\
\text { (CIF) }\end{array}$ & Incineration & $\begin{array}{l}\text { Low-level } \\
\text { Mixed }\end{array}$ & $\begin{array}{l}100,424 \text { solids } \\
340 \text { liquids }\end{array}$ & Operational \\
\hline & CIF Ashcrete Facility & Stabilization & $\begin{array}{l}\text { Low-level } \\
\text { Mixed }\end{array}$ & 2,426 & Operational \\
\hline & 253-H Compactor & Compaction & Low-level & 1,600 (est) & $\begin{array}{l}\text { TBD for } \\
\text { restart }\end{array}$ \\
\hline & $\begin{array}{l}\text { Hazardous } \\
\text { Waste/Mixed Waste } \\
\text { Disposal Facility }\end{array}$ & $\begin{array}{l}\text { Macroencapsulation, } \\
\text { Stabilization }\end{array}$ & $\begin{array}{l}\text { Low-level } \\
\text { Mixed }\end{array}$ & $\begin{array}{l}73 \text { (macro.) } \\
484 \text { (stab.) }\end{array}$ & $\begin{array}{l}\text { Project on } \\
\text { indefinite } \\
\text { hold }\end{array}$ \\
\hline \multirow[t]{2}{*}{ Hanford } & $\begin{array}{l}\text { Waste Receiving \& } \\
\text { Processing Facility, } \\
\text { WRAP I }\end{array}$ & $\begin{array}{l}\text { Compaction } \\
\text { Stabilization }\end{array}$ & Low-level & 1400 & FY97 \\
\hline & $\begin{array}{l}\text { Waste Receiving \& } \\
\text { Processing Facility, } \\
\text { WRAP II }\end{array}$ & $\begin{array}{l}\text { Macroencap- } \\
\text { sulation, } \\
\text { Stabilization }\end{array}$ & $\begin{array}{l}\text { Low-level, } \\
\text { Mixed }\end{array}$ & 1500 & TBD \\
\hline \multirow[t]{2}{*}{ INEL } & $\begin{array}{l}\text { Waste Experimental } \\
\text { Reduction Facility, } \\
\text { WERF }\end{array}$ & $\begin{array}{l}\text { Incineration } \\
\text { stabilization }\end{array}$ & $\begin{array}{l}\text { Low-level, } \\
\text { Mixed }\end{array}$ & $\begin{array}{l}49,625 \text { (incin.) } \\
2765 \text { (stab.) }\end{array}$ & Operational \\
\hline & $\begin{array}{l}\text { HEPA Filter Leaching } \\
\text { System }\end{array}$ & Chemical Extraction & $\begin{array}{l}\text { Low-level, } \\
\text { Mixed }\end{array}$ & 83 & TBD \\
\hline Oak Ridge & TSCA Incinerator & Incineration & $\begin{array}{l}\text { Low-level, } \\
\text { Mixed }\end{array}$ & 15,716 & $\begin{array}{l}\text { Operating, } \\
\text { liquids \& } \\
\text { solids } \\
\end{array}$ \\
\hline \multirow[t]{2}{*}{ Pantex } & Building $11-9$ & Encapsulation & $\begin{array}{l}\text { Low-level } \\
\text { Mixed }\end{array}$ & 43 & TBD \\
\hline & $\begin{array}{l}\text { Hazardous Waste } \\
\text { Treatment } \& \\
\text { Processing Facility }\end{array}$ & $\begin{array}{l}\text { Compaction, } \\
\text { Stabilization, } \\
\text { Encapsulation }\end{array}$ & Low-level & 500 & FY98 \\
\hline
\end{tabular}


If DOE grants an exemption for shipment of APT waste to commercial treatment facilities, Diversified Scientific Services (DSSI) and Scientific Ecology Group (SEG), both in Oak Ridge, TN, could be utilized for low-level PPE/JCW waste streams. The capability for these facilities to accept APT waste contaminated with spallation products and activated materials has not been evaluated. For example their tritium annual release limits are limited to less than $600 \mathrm{Ci}$. Both DSSI and SEG have thermal treatment facilities that can accept low-level waste, and SEG also has stabilization and compaction capabilities. The Envirocare facility in Utah, though more distant from SRS, is another commercial vendor capable of treating APT mixed waste through macroencapsulation or stabilization. DOE Order 5820.2A requires that all DOE LLW be disposed of at a DOE disposal facility, unless an exemption is obtained. Commercially treated APT mixed waste may have to be returned to SRS for storage and eventual disposal at a DOE facility.

At the present time, three DOE disposal sites are known to accept off-site radioactive waste for disposal: SRS, Hanford, and the Nevada Test Site. Barring policy changes, APT low-level waste meeting the site's WAC could be sent to one or more of these facilities. Currently none of these facilities have a PA addressing wastes with the characteristics of APT waste. A new PA will be required for these sites. A formal application and approval process must be completed before waste can be shipped to any of these sites.

The Waste Acceptance Criteria (WAC) of facilities capable of disposal for APT low-level and mixed waste are summarized in the following discussion. All waste approved for off-site treatment and/or disposal must be packaged according to Department of Transportation regulations for shipping of hazardous and/or radioactive materials over public roadways.

All three sites require, upon or immediately after generation and before packaging, the physical and chemical characteristics and radionuclide content of all LLW be determined and recorded for use during all subsequent stages of the waste management process; i.e., on-site treatment, packaging, segregation, transportation, off-site treatment, storage and disposal. Additional sitespecific requirements and restrictions may be found in the WAC for each site. General information about the WAC and contacts at the three DOE low-level and mixed waste disposal site are summarized below. 


\section{DOE Low-Level Waste Disposal Sites, Contacts and WACs}

\begin{tabular}{|l|l|c|c|}
\hline \multicolumn{1}{|c|}{ Site } & \multicolumn{1}{c|}{ Location } & Site Contact & WAC Document \\
\hline \hline Savannah River & $\begin{array}{l}\text { Portions of Aiken, } \\
\text { Barnwell, and } \\
\text { Allendale Counties, } \\
\text { SC }\end{array}$ & $\begin{array}{c}\text { Pam Jenkins } \\
(803) 725-1541\end{array}$ & WSRC-1S \\
\hline Hanford & Richland, WA & $\begin{array}{c}\text { Clay Hawkes } \\
(509) 372-0508\end{array}$ & WHC-EP-0063 \\
\hline Nevada Test Site & Nye County, NV & $\begin{array}{c}\text { Wendy Griffin } \\
(702) 295-5751\end{array}$ & NVO-325, Rev. 1 \\
\hline
\end{tabular}

\section{C3.1 Hanford}

The Hanford Waste Receiving and Processing Facilities (WRAP I and II) are designed to prepare on-site low-level waste (WRAP I) and mixed low-level waste (WRAP IIA) for disposal. WRAP I includes systems for adsorption, compaction, stabilization and packaging. Wrap I groundbreaking ceremonies were held on April 15,1994, and construction is scheduled to be completed in December, 1996. WRAP II, at the KD-0 stage, will conduct waste grouting, macroencapsulation and stabilization operations. WRAP II is not expected to be built. An incineration facility with a design capacity of $550 \mathrm{~m}^{3} / \mathrm{yr}$ is planned but not approved.

Hanford has established WAC WHC-EP-0063-4, UC-721 (November 1993) for off-site generators of radioactive waste interested in sending waste to Hanford.

\section{C3.2 Nevada Test Site (NTS)}

The Nevada Test Site (NTS) is a potential disposal site for low-level waste, but has no on-site treatment facilities. The NTS has established WAC NVO-325, Rev 1, June 1992, "Nevada Test Site Defense Waste Acceptance Criteria, Certification and Transfer Requirements," for off-site generators interested in sending waste to NTS.

\section{C3.3 Scientific Ecology Group (SEG)}

1560 Bear Creek Road, Oak Ridge, TN 37831-2530, Tel: (615) 481-0222

SEG is a subsidiary of Westinghouse Electric Company. The SEG facility near Oak Ridge, Tennessee, is permitted and capable of compacting, incinerating and stabilizing low-level 
radioactive waste. Other capabilities include metal melting, wet waste processing, decontamination, processing of sealed radioactive sources and drying/incineration of resins and sludges. SEG is not permitted to treat mixed waste from outside the state of Tennessee and it is not permitted as a disposal site.

The governing WAC for waste receipt and treatment at SEG is OP-4.35. Different,wastes and treatments are governed by different packaging, receipt, waste form, radiation level and radiological criteria. Some APT relevant criteria for compaction, incineration and metal melting are discussed below.

Generally, the following wastes are not acceptable for compaction:

- RCRA/TSCA hazardous wastes

- Explosives

- Pyrophoric materials

- Flammable solids

- Liquid

- Absorbed liquid

- Smoke detectors

- Gas containers

- Gas sources

- Aerosol cans (unless punctured)

- Animal/biological waste

- $\mathrm{Kr}-85$ Electron tubes

Bulk and non-bulk dry active waste of most cellulosic and polymeric materials are acceptable for incineration. Materials not acceptable for incineration include the following:

- Sharps

- Metal

- Glass

- Polyvinyl chloride (PVC)

- Asbestos

- RCRATSCA hazardous wastes

- Explosives

- Pyrophorics

Contaminated oils and aqueous liquids are accepted for incineration. Contaminated oils acceptable for incineration include petroleum-based lubricating and heating oils such as kerosene, hydraulic oil, diesel fluid and other flammable oils. There are restrictions on viscosity, 
solids and aqueous liquid content, flashpoint and RCRA/TSCA limits. Of particular interest to $\mathrm{APT}$ is that the tritium content must be $\leq 3.0 \times 10^{-3} \mu \mathrm{Ci} / \mathrm{ml}$ and halogens must be $\leq 1000 \mathrm{ppm}$.

Similarly, aqueous liquids may be incinerated at SEG. There are restrictions on $\mathrm{pH}, \%$ solids, chelating agents and oil content, flashpoint and RCRA/TSCA limits. As with contaminated oil, the tritium content must be $\leq 3.0 \times 10^{-3} \mu \mathrm{Ci} / \mathrm{ml}$.

\section{C3.4 Diversified Scientific Services, Inc. (DSSI)}

657 Gallaher Road, Kingston, Tennessee 37763, Tel: (423) 376-8702

DSSI is a subsidiary of Chemical Waste Management, Inc. The DSSI facility near Oak Ridge Tennessee is permitted and capable of energy recovery from low-level and mixed waste.

\section{C3.5 Envirocare}

46 West Broadway, Suite 240, Salt Lake City, Utah 84101, Tel: (801) 532-1330

Envirocare of Utah, Inc. is the only commercial facility in the United States permitted to accept MLLW for disposal. Envirocare is licensed to accept both low-level and mixed waste, including NRC Class A LLW, debris, by-product material (e.g., uranium and thorium mill tailings), and Flisted debris. Concentrations of listed contaminants must be below RCRA treatment standards. In addition to requiring a detailed description of the waste, its history, physical properties, and chemical and radioactive constituents, Envirocare requires that the following analytical data be supplied for each MLLW:

- Gamma spectral analysis for all naturally occurring and man-made radionuclides. If radionuclides are known to be present that cannot be easily quantified by gamma spectroscopy, radiochemical analysis must be provided.

- Paint Filter Liquids Test, EPA Method 9095, for dry solids and stabilized wastes.

- TCLP results for heavy metals and volatile and semi-volatile organics.

- Proctor test for soils.

All analyses must be performed at either a laboratory approved by Envirocare or an EPA Contract Laboratory Program laboratory. Five 1 -kg representative waste samples must be sent to Envirocare and may be analyzed by them prior to waste acceptance.

\section{C3.6 GTS Duratek}


A contract has been awarded to GTS Duratek to design, build and operate a vitrification process, which will transform SRS M-Area mixed wastes into a form meeting land disposal restrictions (LDRs). M-Area wastes making up the design basis for the vitrification process are:

- M-Area plating line sludge from supernatant treatment

- M-Area high nickel plating line sludge

- M-Area treatability test samples

- Filtercake from Mark 15 filters

- Nickel plating line solution

- Plating line sump material

The above wastes will be blended into a homogenized mixture in existing tanks in M Area. Stabilizing chemicals and glass-forming materials will be added to the mixture to make vitrification feedstock. The feedstock will be pumped into a melter at a temperature of about $1150^{\circ} \mathrm{C}$. The glass-forming materials chemically bond the constituents of concern into a matrix of borosilicate glass. The glass is placed into containers for storage and disposal. The entire operation takes place in a structure with secondary confinement and air emission control equipment.

The Duratek vitrification facility is being sized for about 5 tons of throughput per day. After treating the M-Area waste it may be possible to treat other mixed or low-level waste streams, including any suitable APT wastes. To be a viable option, it is assumed the service life of the vitrification facility may be significantly extended. A new contract or contract modification would have to be established with GTS Duratek.

\section{C4. Treatment Technologies}

Treatment technologies applicable to APT waste include compaction, thermal desorption, incineration, stabilization, vitrification, encapsulation and metals recovery. The following descriptions of the technologies are taken from the APT Process Waste Assessment (SNL Report SAND94-2217, UC-721, September 1995).

\section{C4.1 Compaction}

While the greatest volume reduction of PPE job control waste would be achieved through incineration, where this is not feasible, compaction should be seriously considered. During compaction a drum of waste may experience an area force of $4-5 \mathrm{M} \mathrm{lbs}$, depending on the equipment. Under this force, job control waste usually reaches a density of $880-950 \mathrm{~kg} / \mathrm{m}^{3}$. This corresponds to a volume reduction factor of 3-5. Trace amounts of radioactivity poses no particular problem for compaction of less contaminated waste, such as PPE job control waste. 
Compaction of SRS job control low-level waste has been done at SEG in Oak Ridge in 1996. Compacted waste was returned to SRS for disposal in the EAV.

To maximize utility of the EAV tritium bulk cell and silo capacities, volume reduction of APT LLRW is highly desirable. One major consideration would be the specific activity levels associated with the APT waste streams.

\section{C4.2 Thermal Desorption}

Thermal desorption consists of heating waste to a point where volatile liquid contaminants can be driven off. The vapor may be condensed by cooling or absorbed in activated carbon. Since waste containing $>1 \%$ free standing liquid is not acceptable for disposal, this process is often used to drive off residual liquid prior to waste compaction. If a radioactive waste is mixed due to the presence of organic solvents, thermal desorption removes the hazardous constituents, under the debris rule, leaves a low-level waste. This treatment can potentially be used for APT waste streams such as absorbent wipes and solvent rags; however, if activated carbon is used, it becomes a secondary waste stream requiring treatment (e.g. incineration) or disposal. There is a possibility a thermal desorption process will require a RCRA permit if RCRA materials are processed. The APT is being designed not to use any RCRA regulated solvents or oils so this is unlikely to be a factor for APT.

\section{C4.3 Incineration}

Incineration is the thermal decomposition of organic constituents through high temperature (760 $-1550^{\circ} \mathrm{C}$ ) oxidation reactions. Hydrocarbon wastes are converted to carbon dioxide and water vapor; wastes containing nitrogen, sulfur, and/or halogens produce nitrites, nitrates, ammonia, sulfites, sulfates, and halogen acids, respectively. Air particulates are filtered and exhaust gases are cooled, scrubbed, and neutralized in an air emissions control system prior to release to the system exhaust stack. Ash residues can be stabilized in cement or vitrified into a glass-like solid for disposal.

Solid wastes are generally treated in a rotary kiln furnace or a fixed hearth furnace. Wastes are fed to the combustion chamber a number of different ways: using rams, gravity feed, air lock feeders, vibratory or screw feeders, or belt feeders. Containerized waste is gravity-fed or ramfed. The rotary kiln furnace is a refractory or metal-lined cylinder, mounted at a slight incline from horizontal, that slowly rotates to enhance the mixing of solids with combustion air. A forced-draft air circulation system provides oxygen for combustion and turbulence for mixing. The rotation also moves the ash to the lower end of the kiln, where it is removed. Rotary kiln systems usually have a secondary combustion chamber, or afterburner, following the kiln, for further combustion of volatilized waste components. 
Fixed hearth, or controlled air or starved air incineration, is a two-stage process. Waste is ramfed into the primary chamber, where it is burned in a "starved" atmosphere whose oxygen content is insufficient for complete combustion. The products of incomplete combustion, primarily carbon monoxide and volatile hydrocarbons, pass into a secondary chamber where additional air is injected to complete the combustion process. Due to the reduced air flow in the primary chamber, combustion gas velocities are lower, and, as a result, there is less entrainment and carryover of ash particulates into the secondary chamber and the exhaust gases.

A plasma arc centrifugal furnace can be used for the incineration of radioactive waste. This system uses plasma energy to vitrify material dropped into a tub spinning at $20-50 \mathrm{rpm}$. The tub has an axial hole for tapping slag, which cools into a glass-like solid that is a leach-resistant, homogeneous product. A metal layer forms on top of the slag, and can be drawn off separately. Organics are burned to completion in a secondary combustion chamber. The advantages of this system for radioactive waste treatment are:

- Metals separation, combustion of organics and solidification of residue can be achieved with a single process.

- Because there is only one system, waste handling is minimized.

Incineration is the recommended treatment for incinerable APT job control waste. Shredding of this waste prior to combustion will increase combustion efficiency, however, it is not necessary and is not planned for feeding the $\mathrm{CIF}$ at this time. Incineration followed by vitrification or stabilization of residues will generally reduce the initial waste volume by about a factor of 20 . During trial burns, the Waste Experimental Reduction Facility (WERF) incinerator at the INEL has achieved volume reduction factors as high as 80 .

Incineration of APT waste will result in radioactive contamination, to include tritium, in the exhaust gases. Some of this will adhere to particulates and be trapped in the exhaust HEPA filters. As exhaust gases are rapidly cooled and water vapor condenses, some of the remaining radionuclides should be trapped by the scrubber system; however, most will go up the stack as gases and tritiated water vapor (J. D. Brady, "Fate of Tritium, Carbon-14, and Iodine-131 in Wet Scrubber Air Pollution Control Systems on Chemical and Medical Waste Incinerators", 1992 Incineration Conference, Albuquerque, New Mexico, May 11-15, 1992.). Stack gas should be monitored so the permitted radionuclide release limits are not exceeded. Exhaust gas filters and scrubber solutions will be secondary waste streams.

\section{C4.4 Stabilization}

Stabilization immobilizes hazardous heavy metals by chemically binding them in a solid matrix. This decreases the potential for metals to leach out after disposal if the waste were to be exposed 
to moisture or weak acids. The two most common stabilization agents are Portland cement and lime/pozzolan.

While cement-based products are commonly used for stabilization of inorganic solids and aqueous liquids, a series of non-hazardous compounds based on Montmorillonite clay can be used to stabilize aqueous liquids, organic liquids such as used oil, and organic/aqueous liquid mixtures. These compounds are sold under the trade names Aquaset and Petroset.

The estimated total annual volume of primary APT waste streams for which stabilization is the proposed treatment is approximately 2000 liters per year. This waste is primarily highly tritiated oil or water not suitable for the CIF or NPDES permitted discharge.

\section{C4.5 Vitrification}

Vitrification produces a non-leaching stabilized waste form of high integrity and minimal secondary waste. Vitrification processes involve dissolving waste at high temperatures (1100 $1400^{\circ} \mathrm{C}$ ) in a pool of molten glass that usually consists of soda ash, lime, silica, boron oxide, and other glassmaking constituents. Molten glass is periodically withdrawn from the bottom of the furnace and cooled. This process is an alternative to stabilization for immobilization of incinerator ash prior to disposal. Vitrification is also suitable for ion exchange resins, chemical cleaning and decontamination solutions, and inorganic sludges and slurries; however, from an energy use standpoint, it is only practical for large volume waste streams generated on a regular basis.

Vitrification is an effective means of immobilizing both hazardous inorganic and radioactive constituents. Both alpha and beta emitters will be sealed in the glass matrix, and, if gammaemitting radionuclides are present, the gamma dose rate will be attenuated or reduced as a result of the increased density of the vitrification matrix.

If the new treatment standards proposed by EPA for toxic metals (Proposed Rules, Federal Register, Vol. 58, No. 176, September 14, 1993) are implemented, the Toxicity Characteristic Leaching Procedure (TCLP) concentration limit for chromium will decrease by a factor of 15 , from the current $5.0 \mathrm{mg} / \mathrm{l}$ to $0.33 \mathrm{mg} / \mathrm{l}$ for non-wastewater. Cemented wastes may not meet this limit, but tests using wastewater treatment sludges and ion exchange resins have shown that vitrified waste should meet this limit (J. B. Mason, "Modular Enviroglass ${ }^{\mathrm{TM}}$ Vitrification Technology for Low-Level Radioactive and Mixed Wastes," VECTRA Document No. SP-501001, Rev. 2, VECTRA Technologies, Inc., Richland, WA.).

\section{C4.6 Encapsulation}


Encapsulation is primarily applicable to solid waste containing hazardous metal constituents, such as discarded circuit boards or instrumentation. The waste is dried, possibly shredded, mixed with an organic polymer (e.g., polyethylene), thermosetting resin, or asphalt at $120-130$ ${ }^{\circ} \mathrm{C}$, and allowed to cure into a solid mass prior to disposal. As with all waste immobilization processes, the goal is to minimize leaching after disposal. This process is not suitable for wastes that decompose at these temperatures or that contain strong oxidizers such as nitrites, chlorates, or perchlorates that can react with the binder material.

APT waste streams for where encapsulation is the proposed treatment include unrecyclable batteries, instrumentation, and mixed waste getter beds. Macroencapsulation (encapsulating an entire mass, rather than microencapsulation, which coats individual particles of a waste) is the Best Demonstrated Available Technology (BDAT) for radioactive lead solids.

\section{C4.7 Metals Recovery}

Some of the stainless steel waste generated by APT can be recovered and recycled by melting in a rotary kiln or plasma arc furnace under a reducing atmosphere. There is insufficient waste to justify a metal recycling facility just for APT waste. But opportunity exists for participating in metal recycling facilities underway, as described below.

The DOE Office of Technology Development is funding SRS to conduct a demonstration of the beneficial reuse of stainless recycled radioactive scrap metal. Thousands of tons of stainless steel from obsolete reactor heat exchangers with slight tritium contamination may potentially be recycled. B-25 stainless steel containers cast from recycled metal have been made for use at Oak Ridge to support the Transportable Vitrification System. In South Carolina, metal recycling and container fabrication has been contracted to Carolina Metals, Inc., in Barnwell, SC.

Retech Inc. (Ukiah, CA) has signed a cooperative research and development agreement with INEL to develop melting technologies that will allow reuse of radioactivity contaminated metals. Using its plasma arc centrifugal furnace technology, Retech will melt stainless steel containing surrogates for radioactive constituents and evaluate the fate of the surrogates during the process of melting, pouring and cooling the test metal. 
Fig. C-1 APT Waste Management Facilities

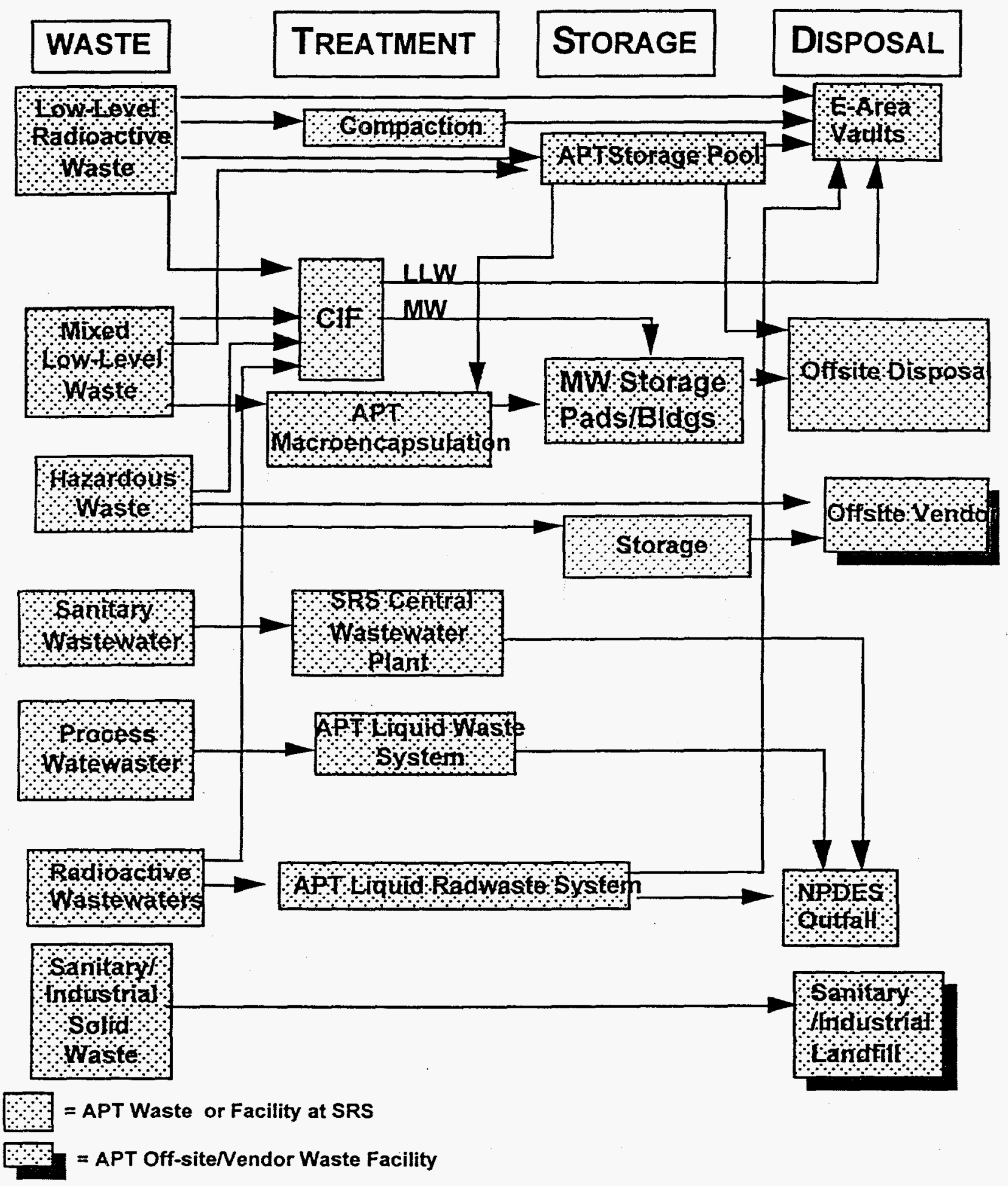




\section{APPENDIX D}

\section{Waste Stream Inventory by Waste Type}

Appendix D lists the masses $(\mathrm{kg})$, volumes $\left(\mathrm{m}^{3}\right)$, and average bulk density $\left(\mathrm{kg} / \mathrm{m}^{3}\right)$ by waste type (low-level radioactive waste, mixed low-level waste, hazardous waste, and radioactive liquid waste) for each waste stream discussed in Appendix B. Some waste streams are included even though projected quantities are determined to be none at this time. Due to round-off of masses and volumes, several average bulk densities vary slightly that should otherwise be the same (e.g., all job control waste streams should have the same average bulk density). Each category of waste totals are rounded off. 


\section{APT Low-Level Radioactive Waste Streams}

\begin{tabular}{|c|c|c|c|c|}
\hline $\begin{array}{c}\text { Waste Stream } \\
\text { Number }\end{array}$ & $\begin{array}{l}\text { Waste Stream } \\
\text { Description }\end{array}$ & $\begin{array}{l}\text { Mass } \\
\mathrm{kg} / \mathrm{yr}\end{array}$ & $\begin{array}{l}\text { Volume } \\
\mathbf{m}^{3} / \mathbf{y r}\end{array}$ & $\begin{array}{c}\text { Bulk } \\
\text { Density } \\
\text { kg/m } \mathbf{m}^{3} \\
\end{array}$ \\
\hline B1 & Job Control Waste & 130,000 & 1000 & 133 \\
\hline B3 & Nonhazardous Equipment & 476,000 & 350 & 1,360 \\
\hline B3a & U/Mg Beds* & 14,500 & 2.8 & 5,179 \\
\hline $\mathrm{B} 3 \mathrm{~b}$ & Hydride/Catalyst/Zeolite Beds & 55 & 0.14 & 393 \\
\hline B3c & Ion Exchange Resin & 5,700 & 5 & 1143 \\
\hline B3d & Palladium/Electrolysis Membrane & 55 & 0.14 & 393 \\
\hline B3e & HEPA Filters & 55 & 0.28 & 190 \\
\hline B3f & SAES St909 Beds & 250 & 0.5 & 500 \\
\hline B3g & $\begin{array}{c}\text { Spallation Metal Filter } \\
\text { Assemblies }\end{array}$ & 400 & 0.4 & 750 \\
\hline B3h & $\begin{array}{l}\text { Accelerator Components } \\
\text { Containing Niobum }\end{array}$ & 700 & 1.0 & 700 \\
\hline B 10 & Radioactive Oil & 180 & 0.2 & 900 \\
\hline Bl0a & Glovebox Bubbler Fluid & 54 & 0.06 & 700 \\
\hline B 15 & Tungsten & 1,100 & 2 & 1,143 \\
\hline B16 & Window Modules & 100 & 0.5 & 463 \\
\hline $\mathrm{B} 17$ & Steel Shielding & 500 & 1 & 500 \\
\hline $\mathrm{B} 18$ & Aluminum & 1,000 & 2 & 400 \\
\hline B19 & Batteries & 1 & 0.01 & 1,360 \\
\hline B22 & Job Control Waste (LiAl) & 40,000 & 300 & 133 \\
\hline $\mathrm{B} 23$ & Spent LiAl Extraction & 36,500 & 20 & 1,360 \\
\hline B24 & Nonhazardous Equipment (LiAl) & 6,800 & 5 & 1,360 \\
\hline B24a & Furnace Components & 3,400 & 2.5 & 1,360 \\
\hline $\mathrm{B} 24 \mathrm{~b}$ & HEPA Filters (LiAl) & 55 & 0.28 & 190 \\
\hline & Total & 716,000 & 1700 & \\
\hline
\end{tabular}

*APT will probably use either $U$ or Mg beds, but not both. Waste $U$ bed mass and volume are shown here because of their heavier weights; $\mathrm{Mg}$ beds are lighter and bulkier. 


\section{APT Mixed Low-level Waste Streams}

\begin{tabular}{|c|l|c|c|c|}
\hline $\begin{array}{c}\text { Waste Stream } \\
\text { Number }\end{array}$ & \multicolumn{1}{|c|}{$\begin{array}{c}\text { Waste Stream } \\
\text { Description }\end{array}$} & $\begin{array}{c}\text { Mass } \\
\mathbf{k g} / \mathbf{y r}\end{array}$ & $\begin{array}{c}\text { Volume } \\
\mathbf{m}^{\mathbf{3}} / \mathbf{y r}\end{array}$ & $\begin{array}{c}\text { Bulk } \\
\text { Den } \\
\text { sity } \\
\mathbf{k g} / \mathbf{m}^{\mathbf{3}}\end{array}$ \\
\hline \hline B2 & Job Control Waste (Mixed) & 200 & 1.0 & 152 \\
\hline B4 & Palladium/Silver Permeator & 23 & 0.01 & 2,300 \\
\hline B4a & Silver Plated Fittings & 5 & 0.01 & 750 \\
\hline B5 & Mixed/Hazardous Waste Oil & 0 & 0 & - \\
\hline B6 & Mixed Solvent Rags & 0 & 0 & - \\
\hline B7 & Analytical/Rad Con & $*$ & $*$ & - \\
\hline B8 & Chemicals & 6.8 & 0.004 & 1,700 \\
\hline B9 & Mixed Waste Lead & 56,000 & 15 & 3,700 \\
\hline B19 & Batteries & 2 & 0.01 & 1,360 \\
\hline \hline & Total & 56,200 & 16 & \\
\hline
\end{tabular}

*Assume most chemicals will be disposed as hazardous waste. As mixed waste, they are covered in the B2 mixed waste stream.

APT Hazardous Waste Streams

\begin{tabular}{|c|l|r|r|c|}
\hline $\begin{array}{c}\text { Waste Stream } \\
\text { Number }\end{array}$ & \multicolumn{1}{|c|}{$\begin{array}{c}\text { Waste Stream } \\
\text { Description }\end{array}$} & $\begin{array}{c}\text { Mass } \\
\mathbf{k g} / \mathbf{y r}\end{array}$ & $\begin{array}{c}\text { Volume } \\
\mathbf{m}^{\mathbf{3}} / \mathbf{y r}\end{array}$ & $\begin{array}{c}\text { Bulk Density } \\
\mathbf{k g} / \mathbf{m}^{\mathbf{3}}\end{array}$ \\
\hline B19 & Batteries & 500 & 1 & 1,360 \\
\hline B7 & $\begin{array}{c}\text { Analytical/Rad Con } \\
\text { Chemicals }\end{array}$ & 1,256 & 1.3 & 966 \\
\hline B8 & Teledyne Micro-fuel Cells & 4.5 & 0.04 & 1,125 \\
\hline \hline & Total & 1,760 & 3 & \\
\hline
\end{tabular}


APT Radioactive Liquid Waste Streams

\begin{tabular}{|c|l|c|}
\hline $\begin{array}{c}\text { Waste Stream } \\
\text { Number }\end{array}$ & \multicolumn{1}{|c|}{$\begin{array}{c}\text { Waste Stream } \\
\text { Description }\end{array}$} & $\begin{array}{c}\text { Volume } \\
\mathbf{m}^{\mathbf{3}} \mathbf{y r}\end{array}$ \\
\hline \hline B12 & Radioactive Heavy Water & 0.19 \\
\hline B10 & $\begin{array}{l}\text { Non-Hazardous Radioactive } \\
\text { Oil }\end{array}$ & 0.1 \\
\hline B11 & $\begin{array}{l}\text { Radioactive Light Water } \\
\text { and Aqueous Solutions }\end{array}$ & 512 \\
\hline \hline & Total & $\mathbf{5 1 2}$ \\
\hline
\end{tabular}

APT Liquid Waste Streams

\begin{tabular}{|c|l|c|}
\hline $\begin{array}{c}\text { Waste Stream } \\
\text { Number }\end{array}$ & \multicolumn{1}{|c|}{$\begin{array}{c}\text { Waste Stream } \\
\text { Description }\end{array}$} & $\begin{array}{c}\text { Volume } \\
\mathbf{m}^{\mathbf{3}} / \mathbf{y r}\end{array}$ \\
\hline \hline B13 & $\begin{array}{l}\text { Non-Radioactive Process } \\
\text { Wastewater }\end{array}$ & $4,800,000$ \\
\hline B14 & $\begin{array}{l}\text { Sanitary and Industrial } \\
\text { Waste }\end{array}$ & 15,500 \\
\hline \hline & Total & $\mathbf{4 , 8 1 5 , 5 0 0}$ \\
\hline
\end{tabular}

APT Sanitary/Industrial Solid Waste Streams

\begin{tabular}{|c|l|c|c|c|}
\hline $\begin{array}{c}\text { Waste Stream } \\
\text { Number }\end{array}$ & \multicolumn{1}{|c|}{$\begin{array}{c}\text { Waste Stream } \\
\text { Description }\end{array}$} & $\begin{array}{c}\text { Mass } \\
\mathbf{k g} / \mathbf{y r}\end{array}$ & $\begin{array}{c}\text { Volume } \\
\mathbf{m}^{\mathbf{3}} / \mathbf{y r}\end{array}$ & $\begin{array}{c}\text { Bulk Density } \\
\mathbf{k g} / \mathbf{m}^{\mathbf{3}}\end{array}$ \\
\hline \hline B14 & $\begin{array}{l}\text { Sanitary and Industrial } \\
\text { Waste }\end{array}$ & $6,000,000$ & 12,000 & 152 \\
\hline
\end{tabular}




\begin{tabular}{|l|l|r|r|r|}
\hline B19 & Batteries & 50 & 0.1 & 1,360 \\
\hline \hline & Total & $\mathbf{6 , 0 0 0 , 0 0 0}$ & $\mathbf{1 2 , 0 0 0}$ & \\
\hline
\end{tabular}

APT Air Emissions

\begin{tabular}{|c|l|c|}
\hline $\begin{array}{c}\text { Waste Stream } \\
\text { Number }\end{array}$ & \multicolumn{1}{|c|}{$\begin{array}{c}\text { Waste Stream } \\
\text { Description }\end{array}$} & $\begin{array}{c}\text { Mass } \\
\mathbf{k g} / \mathbf{y r}\end{array}$ \\
\hline \hline B20 & Non-Radioactive Air Emissions & 16,000 \\
\hline \hline & Total & $\mathbf{1 6 , 0 0 0}$ \\
\hline
\end{tabular}




\section{APPENDIX E}

\section{Waste Stream Inventory by Type and Source - EIS Format}

The EIS breaks out waste streams by type (low-level radioactive waste, mixed low-level waste or hazardous waste) and source. Normally the source refers to the various project options. Since this PPDA is focused on the APT Project, the source will refer to the range of project options available to the APT. 


\section{Summary - EIS Data}

These APT Waste Streams are Constant with all APT Project Options and Design Choices

\section{APT Low-Level Radioactive Waste Streams}

\begin{tabular}{|c|c|c|c|c|}
\hline $\begin{array}{l}\text { Waste Stream } \\
\text { Number }\end{array}$ & $\begin{array}{l}\text { Waste Stream } \\
\text { Description }\end{array}$ & $\begin{array}{l}\text { Mass } \\
\mathrm{kg} / \mathrm{yr}\end{array}$ & $\begin{array}{l}\text { Volume } \\
m^{3} / y r\end{array}$ & $\begin{array}{c}\text { Bulk } \\
\text { Density } \\
\mathbf{k g} / \mathbf{m}^{\mathbf{3}} \\
\end{array}$ \\
\hline Bl & Job Control Waste & 130,000 & 1000 & 133 \\
\hline B3 & Nonhazardous Equipment & 476,000 & 350 & 1,360 \\
\hline B3a & U/Mg Beds* & 14,500 & 2.8 & 5,179 \\
\hline $\mathrm{B} 3 \mathrm{~b}$ & Hydride/Catalyst/Zeolite Beds & 55 & 0.14 & 393 \\
\hline B3c & Ion Exchange Resin & 5,700 & 5 & 1143 \\
\hline B3d & Palladium/Electrolysis Membrane & 55 & 0.14 & 393 \\
\hline $\mathrm{B} 3 \mathrm{e}$ & HEPA Filters & 55 & 0.28 & 190 \\
\hline B3f & SAES St909 Beds & 250 & 0.5 & 500 \\
\hline $\mathrm{B} 3 \mathrm{~g}$ & $\begin{array}{c}\text { Spallation Metal Filter } \\
\text { Assemblies } \\
\end{array}$ & 400 & 0.4 & 750 \\
\hline B3h & $\begin{array}{l}\text { Accelerator Components } \\
\text { Containing Niobum }\end{array}$ & 700 & 1.0 & 700 \\
\hline $\mathrm{B} 10$ & Radioactive Oil & 180 & 0.2 & 900 \\
\hline $\mathrm{B} 10 \mathrm{a}$ & Glovebox Bubbler Fluid & 54 & 0.06 & 700 \\
\hline B 15 & Tungsten & 1,100 & 2 & 1,143 \\
\hline B16 & Window Modules & 100 & 0.5 & 463 \\
\hline B 17 & Steel Shielding & 500 & 1 & 500 \\
\hline B 18 & Aluminum & 1,000 & 2. & 400 \\
\hline B19 & Batteries & 1 & 0.01 & 1,360 \\
\hline & Total & 669,000 & 1370 & \\
\hline
\end{tabular}

*APT will probably use either $\mathrm{U}$ or $\mathrm{Mg}$ beds, but not both. Waste U bed mass and volume are shown here because of their heavier weights; $\mathrm{Mg}$ beds are lighter and bulkier. 


\section{APT Mixed Low-level Waste Streams}

\begin{tabular}{|c|l|r|r|c|}
\hline $\begin{array}{c}\text { Waste Stream } \\
\text { Number }\end{array}$ & \multicolumn{1}{|c|}{$\begin{array}{c}\text { Waste Stream } \\
\text { Description }\end{array}$} & $\begin{array}{c}\text { Mass } \\
\mathbf{k g} / \mathbf{y r}\end{array}$ & $\begin{array}{c}\text { Volume } \\
\mathbf{m}^{\mathbf{3}} / \mathbf{y r}\end{array}$ & $\begin{array}{c}\text { Bulk Density } \\
\mathbf{k g} / \mathbf{m}^{\mathbf{3}}\end{array}$ \\
\hline \hline B2 & Job Control Waste (Mixed) & 200 & 1.0 & 152 \\
\hline B4 & Palladium/Silver Permeator & 23 & 0.01 & 2,300 \\
\hline B4a & Silver Plated Fittings & 5 & 0.01 & 750 \\
\hline B5 & Mixed/Hazardous Waste Oil & 0 & 0 & - \\
\hline B6 & Mixed Solvent Rags & 0 & 0 & - \\
\hline B7 & Analytical/Rad Con Chemicals & $*$ & $*$ & - \\
\hline B8 & Teledyne Micro-fuel Cells & 6.8 & 0.004 & 1,700 \\
\hline B19 & Batteries & 2 & 0.01 & 1,360 \\
\hline \hline
\end{tabular}

*Assume most chemicals will be disposed as hazardous waste. As mixed waste, they are covered in the B2 mixed waste stream.

APT Hazardous Waste Streams

\begin{tabular}{|c|l|r|r|r|}
\hline $\begin{array}{c}\text { Waste Stream } \\
\text { Number }\end{array}$ & \multicolumn{1}{|c|}{$\begin{array}{c}\text { Waste Stream } \\
\text { Description }\end{array}$} & $\begin{array}{c}\text { Mass } \\
\mathbf{k g} / \mathbf{y r}\end{array}$ & $\begin{array}{c}\text { Volume } \\
\mathbf{m}^{\mathbf{3}} / \mathbf{y r}\end{array}$ & $\begin{array}{c}\text { Bulk Density } \\
\mathbf{k g} / \mathbf{m}^{\mathbf{3}}\end{array}$ \\
\hline \hline B19 & Batteries & 500 & 1 & 1,360 \\
\hline B7 & $\begin{array}{c}\text { Analytical/Rad Con } \\
\text { Chemicals }\end{array}$ & 1,256 & 1.3 & 966 \\
\hline B8 & Teledyne Micro-fuel Cells & 4.5 & 0.04 & 1,125 \\
\hline \hline & Total & 1,760 & 3 & \\
\hline
\end{tabular}


APT Radioactive Liquid Waste Streams

\begin{tabular}{|c|l|c|}
\hline $\begin{array}{c}\text { Waste Stream } \\
\text { Number }\end{array}$ & \multicolumn{1}{|c|}{$\begin{array}{c}\text { Waste Stream } \\
\text { Description }\end{array}$} & $\begin{array}{c}\text { Volume } \\
\mathbf{m}^{\mathbf{3}} / \mathbf{y r}\end{array}$ \\
\hline B12 & Radioactive Heavy Water & 0.19 \\
\hline B10 & $\begin{array}{l}\text { Nonhazardous Radioactive } \\
\text { Oil }\end{array}$ & 0.1 \\
\hline B11 & $\begin{array}{l}\text { Radioactive Light Water } \\
\text { and Aqueous Solutions }\end{array}$ & 524 \\
\hline \hline & Total & $\mathbf{5 2 4}$ \\
\hline
\end{tabular}

APT Sanitary/Industrial Solid Waste Streams

\begin{tabular}{|c|l|r|r|r|}
\hline $\begin{array}{c}\text { Waste Stream } \\
\text { Number }\end{array}$ & \multicolumn{1}{|c|}{$\begin{array}{c}\text { Waste Stream } \\
\text { Description }\end{array}$} & $\begin{array}{c}\text { Mass } \\
\mathbf{k g} / \mathbf{y r}\end{array}$ & $\begin{array}{c}\text { Volume } \\
\mathbf{m}^{\mathbf{3}} / \mathbf{y r}\end{array}$ & $\begin{array}{c}\text { Bulk Density } \\
\mathbf{k g} / \mathbf{m}^{\mathbf{3}}\end{array}$ \\
\hline \hline $\mathrm{B} 14$ & $\begin{array}{l}\text { Sanitary and Industrial } \\
\text { Waste }\end{array}$ & $6,000,0000$ & 12,000 & 152 \\
\hline $\mathrm{B} 19$ & Batteries & 50 & 0.1 & 1,360 \\
\hline \hline & Total & $\mathbf{6 , 0 0 0 , 0 0 0}$ & $\mathbf{1 2 , 0 0 0}$ & \\
\hline
\end{tabular}

APT Air Emissions

\begin{tabular}{|c|l|c|}
\hline $\begin{array}{c}\text { Waste Stream } \\
\text { Number }\end{array}$ & \multicolumn{1}{|c|}{$\begin{array}{c}\text { Waste Stream } \\
\text { Description }\end{array}$} & $\begin{array}{c}\text { Mass } \\
\mathbf{k g} / \mathbf{y r}\end{array}$ \\
\hline \hline $\mathrm{B} 20$ & Non-Radioactive Air Emissions & 16,000 \\
\hline \hline & Total & $\mathbf{1 6 , 0 0 0}$ \\
\hline
\end{tabular}


LiAl Extraction or Helium-3 Waste - Data for EIS

APT Low-Level Radioactive Waste Streams

\begin{tabular}{|c|l|c|c|c|}
\hline $\begin{array}{c}\text { Waste Stream } \\
\text { Number }\end{array}$ & \multicolumn{1}{|c|}{$\begin{array}{c}\text { Waste Stream } \\
\text { Description }\end{array}$} & $\begin{array}{c}\text { Mass } \\
\mathbf{k g} / \mathbf{y r}\end{array}$ & $\begin{array}{c}\text { Volume } \\
\mathbf{m}^{\mathbf{3}} / \mathbf{y r}\end{array}$ & $\begin{array}{c}\text { Bulk } \\
\text { Density } \\
\mathbf{k g} / \mathbf{m}^{\mathbf{3}}\end{array}$ \\
\hline \hline B22 & Job Control Waste (LiAl) & 40,000 & 300 & 133 \\
\hline B23 & Spent LiAl Extraction & 36,500 & 20 & 1,360 \\
\hline B24 & Nonhazardous Equipment (LiAl) & 6,800 & 5 & 1,360 \\
\hline B24a & Furnace Components & 3,400 & 2.5 & 1,360 \\
\hline B24b & HEPA Filters (LiAl) & 55 & 0.28 & 190 \\
\hline \hline & Total & $\mathbf{4 7 , 0 0 0}$ & $\mathbf{3 3 0}$ & \\
\hline
\end{tabular}

APT Mixed Low-level Waste Streams

\begin{tabular}{|c|l|c|c|}
\hline $\begin{array}{c}\text { Waste Stream } \\
\text { Number }\end{array}$ & $\begin{array}{c}\text { Waste Stream } \\
\text { Description }\end{array}$ & $\begin{array}{c}\text { Mass } \\
\mathbf{k g} / \mathbf{y r}\end{array}$ & $\begin{array}{c}\text { Volume } \\
\mathbf{m}^{\mathbf{3}} / \mathbf{y r}\end{array}$ \\
\hline \hline B9 & Mixed Waste Lead (LiAl) & 56,000 & 15 \\
\hline B9 & Mixed Waste Lead $\left(\mathrm{He}^{3}\right)$ & 44,000 & 12 \\
\hline
\end{tabular}

APT Liquid Waste Streams

\begin{tabular}{|c|l|c|}
\hline $\begin{array}{c}\text { Waste Stream } \\
\text { Number }\end{array}$ & \multicolumn{1}{|c|}{$\begin{array}{c}\text { Waste Stream } \\
\text { Description }\end{array}$} & $\begin{array}{c}\text { Volume } \\
\mathbf{m}^{\mathbf{3}} / \mathbf{y r}\end{array}$ \\
\hline \hline $\mathrm{B} 14$ & $\begin{array}{l}\text { Sanitary and Industrial } \\
\text { Waste (Li-Al) }\end{array}$ & $\mathbf{1 4 , 7 0 0}$ \\
\hline $\mathrm{B} 14$ & $\begin{array}{l}\text { Sanitary and Industrial } \\
\text { Waste (All other options) }\end{array}$ & 15,500 \\
\hline \hline & Total & $\mathbf{1 5 , 5 0 0}$ \\
\hline
\end{tabular}


Superconducting/Room Temperature - Data for EIS

\begin{tabular}{|c|l|c|}
\hline $\begin{array}{c}\text { APT Liquid Waste Streams } \\
\text { Number }\end{array}$ & \multicolumn{1}{|c|}{$\begin{array}{c}\text { Waste Stream } \\
\text { Description }\end{array}$} & $\begin{array}{c}\text { Volume } \\
\mathbf{m}^{\mathbf{3}} / \mathbf{y r}\end{array}$ \\
\hline \hline B13 & $\begin{array}{l}\text { Non-Radioactive Process } \\
\text { Wastewater } \\
\text { (Room Temperature) }\end{array}$ & $\mathbf{4 , 8 0 0 , 0 0 0}$ \\
\hline B13 & $\begin{array}{l}\text { Non-Radioactive Process } \\
\text { Wastewater } \\
\text { (Superconducting) }\end{array}$ & $3,500,000$ \\
\hline
\end{tabular}




\section{APPENDLX F}

\section{Waste Stream Inventory by Waste Treatment Category}

Appendix $\mathrm{F}$ lists the masses $(\mathrm{kg})$, volumes $\left(\mathrm{m}^{3}\right)$ and bulk densities $\left(\mathrm{kg} / \mathrm{m}^{3}\right)$ for each low-level radioactive waste, mixed low-level waste, hazardous waste, and sanitary/industrial stream by waste treatment category and disposal option. Several waste streams have multiple treatment/disposal options available, based on waste form and radionuclide content. These options are discussed in detail for each waste stream in Appendix B. Each category of waste totals are rounded off. 
Incineration and Stabilization of Residue

A. Low-Level Radioactive Waste

\begin{tabular}{|c|l|c|c|c|}
\hline $\begin{array}{c}\text { Waste Stream } \\
\text { Number }\end{array}$ & \multicolumn{1}{|c|}{$\begin{array}{c}\text { Waste Stream } \\
\text { Description }\end{array}$} & $\begin{array}{c}\text { Mass } \\
\mathbf{k g} / \mathbf{y r}\end{array}$ & $\begin{array}{c}\text { Volume } \\
\mathbf{m}^{\mathbf{3}} / \mathbf{y r}\end{array}$ & $\begin{array}{c}\text { Bulk Density } \\
\mathbf{k g} / \mathbf{m}^{\mathbf{3}}\end{array}$ \\
\hline \hline B1 & Job Control Waste & 65,000 & 500 & 133 \\
\hline B3c & Ion Exchange Resins & 2,850 & 2.5 & 1143 \\
\hline B7 & $\begin{array}{l}\text { Analytical Lab/Rad Con } \\
\text { Chemicals }\end{array}$ & 390 & 0.4 & 600 \\
\hline B10 & Radioactive Oil & 90 & 0.10 & 900 \\
\hline B10a & Glovebox Bubbler Fluid & 18 & 0.02 & 900 \\
\hline B22 & JCW (LiAl) & 20,000 & 150 & 133 \\
\hline Total & & 88,500 & 650 & \\
\hline
\end{tabular}

B. Mixed Low-level Waste

\begin{tabular}{|c|l|c|c|c|}
\hline $\begin{array}{c}\text { Waste Stream } \\
\text { Number }\end{array}$ & \multicolumn{1}{|c|}{$\begin{array}{c}\text { Waste Stream } \\
\text { Description }\end{array}$} & $\begin{array}{c}\text { Mass } \\
\mathbf{k g} / \mathbf{y r}\end{array}$ & $\begin{array}{c}\text { Volume } \\
\mathbf{\mathbf { m } ^ { 3 }} / \mathbf{y r}\end{array}$ & $\begin{array}{c}\text { Bulk Density } \\
\mathbf{k g} / \mathbf{m}^{\mathbf{3}}\end{array}$ \\
\hline \hline B2 & Job Control Waste (Mixed) & 100 & 0.5 & 152 \\
\hline B5 & Mixed/Hazardous Waste Oil & 0 & 0 & \\
\hline B6 & Mixed Solvent Rags & 0 & 0 & \\
\hline Total & & 100 & 0.5 & \\
\hline
\end{tabular}

\section{Hazardous Waste}

\begin{tabular}{|c|l|c|c|c|}
\hline $\begin{array}{c}\text { Waste Stream } \\
\text { Number }\end{array}$ & \multicolumn{1}{|c|}{$\begin{array}{c}\text { Waste Stream } \\
\text { Description }\end{array}$} & $\begin{array}{c}\text { Mass } \\
\mathbf{k g} / \mathbf{y r}\end{array}$ & $\begin{array}{c}\text { Volume } \\
\mathbf{m}^{\mathbf{3}} \mathbf{y r}\end{array}$ & $\begin{array}{c}\text { Bulk Density } \\
\mathbf{k g} / \mathbf{m}^{\mathbf{3}}\end{array}$ \\
\hline \hline B5 & Mixed/Hazardous Oil & - & - & - \\
\hline B7 & $\begin{array}{l}\text { Analytical Lab/Rad Con } \\
\text { Chemicals* }\end{array}$ & 390 & 0.04 & 600 \\
\hline Total & & 390 & 0.04 & \\
\hline
\end{tabular}

*Includes approximately $180 \mathrm{lb}(82 \mathrm{~kg})$ of pump oil from Appendix B Waste Stream B12 inventory list. A Specific Gravity of $0.9\left(900 \mathrm{~kg} / \mathrm{m}^{3}\right)$ for oil is assumed. 


\section{Compaction for EAV LAW Vault Disposal}

\section{A. Low-Level Radioactive Waste}

\begin{tabular}{|c|l|c|c|c|}
\hline $\begin{array}{c}\text { Waste Stream } \\
\text { Number }\end{array}$ & \multicolumn{1}{|c|}{$\begin{array}{c}\text { Waste Stream } \\
\text { Description }\end{array}$} & $\begin{array}{c}\text { Mass } \\
\mathbf{k g} / \mathbf{y r}\end{array}$ & $\begin{array}{c}\text { Volume } \\
\mathbf{m}^{\mathbf{3}} / \mathbf{y r}\end{array}$ & $\begin{array}{c}\text { Bulk Density } \\
\mathbf{k g} / \mathbf{m}^{\mathbf{3}}\end{array}$ \\
\hline \hline B1 & Job Control Waste & 10,000 & 75 & 133 \\
\hline B22 & $\begin{array}{l}\text { Job Control Waste } \\
\text { (Extraction) }\end{array}$ & 10,000 & 75 & 133 \\
\hline Total & & 20,000 & 150 & \\
\hline
\end{tabular}

Direct Disposal to LAW Vaults

A. Low-Level Radioactive Waste

\begin{tabular}{|c|l|r|r|c|}
\hline $\begin{array}{c}\text { Waste Stream } \\
\text { Number }\end{array}$ & \multicolumn{1}{|c|}{$\begin{array}{c}\text { Waste Stream } \\
\text { Description }\end{array}$} & $\begin{array}{c}\text { Mass } \\
\mathbf{k g} / \mathbf{y r}\end{array}$ & $\begin{array}{c}\text { Volume } \\
\mathbf{m}^{\mathbf{3} / \mathbf{y r}}\end{array}$ & $\begin{array}{c}\text { Bulk Density } \\
\mathbf{k g} / \mathbf{m}^{\mathbf{3}}\end{array}$ \\
\hline \hline B1 & Job Control Waste & 55,000 & 425 & 133 \\
\hline B3 & Process Equipment & 408,000 & 300 & 1,360 \\
\hline B3b & Hydride Beds & 55 & 0.14 & 393 \\
\hline B3c & lon Exchange Resins & 2,850 & 2.5 & 1143 \\
\hline B3d & Palladium/ Electrolysis & 55 & 0.14 & 393 \\
\hline B3e & HEPAs & 55 & 0.28 & 190 \\
\hline B3f & SAES St909 Beds & 250 & 0.5 & 500 \\
\hline B3g & Spallation Metal Filter & 400 & 0.4 & 750 \\
\hline B10 & Aadioactive Oil* & & & 900 \\
\hline B10a & Glovebox Bubbler Fluid* & 36 & 0.04 & 900 \\
\hline B11 & Radioactive Light & 24000 & 24 & 1000 \\
\hline B18 & Water/Aqueous Solutions & & & 400 \\
\hline B19 & Bluminum & 1,000 & 2 & 1,360 \\
\hline B22 & Job Control Waste (LiAl) & 10,000 & 75 & 133 \\
\hline B24 & Equipment (LiAl Extraction) & 3,400 & 2.5 & 1,360 \\
\hline B24b & HEPAs & 55 & 0.28 & 190 \\
\hline Total & & 506,000 & 836 & \\
\hline
\end{tabular}

*These liquids are stabilized before disposal. 


\section{Direct Disposal to ILTV Silos}

\section{A. Low-Level Radioactive Waste (Intermediate Level Waste)}

\begin{tabular}{|c|c|c|c|c|}
\hline $\begin{array}{c}\text { Waste Stream } \\
\text { Number }\end{array}$ & $\begin{array}{c}\text { Waste Stream } \\
\text { Description }\end{array}$ & $\begin{array}{c}\text { Mass } \\
\mathbf{k g} / \mathbf{y r}\end{array}$ & $\begin{array}{c}\text { Volume } \\
\mathbf{m}^{\mathbf{3}} / \mathbf{y r}\end{array}$ & $\begin{array}{c}\text { Bulk Density } \\
\mathbf{k g} / \mathbf{m}^{\mathbf{3}}\end{array}$ \\
\hline \hline B23 & Spent LiAl Extraction & 36,500 & 20 & 1,360 \\
\hline Total & & 36,500 & 20 & \\
\hline
\end{tabular}

Direct Disposal to ILTV Bulk Cell

A. Low-Level Radioactive Waste (Intermediate Level Waste)

\begin{tabular}{|c|c|c|c|c|}
\hline $\begin{array}{c}\text { Waste Stream } \\
\text { Number }\end{array}$ & $\begin{array}{c}\text { Waste Stream } \\
\text { Description }\end{array}$ & $\begin{array}{l}\text { Mass } \\
\mathrm{kg} / \mathrm{yr}\end{array}$ & $\begin{array}{c}\text { Volume } \\
\mathrm{m}^{3} / \mathrm{yr} \\
\end{array}$ & $\begin{array}{c}\text { Bulk Density } \\
\mathrm{kg} / \mathbf{m}^{3}\end{array}$ \\
\hline B3 & Process Equipment & 68,000 & 50 & 1,360 \\
\hline $\mathrm{B3a}$ & $\mathrm{U} / \mathrm{Mg}$ Beds & 14,500 & 2.8 & 5,179 \\
\hline B24 & Equipment (LiAl Extraction) & 3,400 & 2.5 & 1,360 \\
\hline B24a & LiAl Furnace & 3,400 & 2.5 & 1,360 \\
\hline Total & & 89,300 & 58 & \\
\hline
\end{tabular}

Interim Storage/Off-site Disposal or Disposal to be Determined

A1. Low-Level Radioactive Waste (NPDES Outfall)

\begin{tabular}{|c|c|c|}
\hline $\begin{array}{c}\text { Waste Stream } \\
\text { Number }\end{array}$ & $\begin{array}{c}\text { Waste Stream } \\
\text { Description }\end{array}$ & $\begin{array}{c}\text { Volume } \\
\mathbf{m}^{\mathbf{3}} / \mathbf{y r}\end{array}$ \\
\hline \hline B11 & $\begin{array}{c}\text { Radioactive Light Water } \\
\text { and Aqueous Solutions }\end{array}$ & 500 \\
\hline \hline Total & & 500 \\
\hline
\end{tabular}




\section{A2. Low-Level Radioactive Waste}

\begin{tabular}{|c|c|c|c|c|}
\hline $\begin{array}{l}\text { Waste Stream } \\
\text { Number }\end{array}$ & $\begin{array}{l}\text { Waste Stream } \\
\text { Description }\end{array}$ & $\begin{array}{l}\text { Mass } \\
\mathrm{kg} / \mathrm{yr}\end{array}$ & $\begin{array}{l}\text { Volume } \\
\mathrm{m}^{3} / \mathrm{yr}\end{array}$ & $\begin{array}{c}\text { Bulk } \\
\text { Density } \\
\text { kg/m } \mathbf{m}^{3}\end{array}$ \\
\hline B3h & $\begin{array}{l}\text { Accelerator Components } \\
\text { Containing Niobum }\end{array}$ & 700 & 1.0 & 700 \\
\hline $\mathrm{B} 15$ & Tungsten & 1,100 & 2 & 1,143 \\
\hline B16 & Window Modules & 100 & 0.5 & 463 \\
\hline B17 & Steel Shielding & 500 & 1 & 500 \\
\hline Total & & 2,400 & 5 & \\
\hline
\end{tabular}

B. Mixed Low-Level Waste

\begin{tabular}{|c|l|c|c|c|}
\hline $\begin{array}{c}\text { Waste Stream } \\
\text { Number }\end{array}$ & \multicolumn{1}{|c|}{$\begin{array}{c}\text { Waste Stream } \\
\text { Description }\end{array}$} & $\begin{array}{c}\text { Mass } \\
\mathbf{k g} / \mathbf{y r}\end{array}$ & $\begin{array}{c}\text { Volume } \\
\mathbf{m}^{\mathbf{3}} / \mathbf{y r}\end{array}$ & $\begin{array}{c}\text { Bulk Density } \\
\mathbf{k g} / \mathbf{m}^{\mathbf{3}}\end{array}$ \\
\hline \hline B2 & Job Control Waste Mixed) & 100 & 0.5 & 152 \\
\hline B4 & Palladium/Silver Permeator & 23 & 0.01 & 2,300 \\
\hline B4a & Silver Plated Fittings & 5 & 0.01 & 750 \\
\hline B8 & $\begin{array}{l}\text { Oxygen Sensor Micro-fuel } \\
\text { Cells }\end{array}$ & 6.8 & 0.004 & 1,700 \\
\hline B9 & Mixed Waste Lead & 44,000 & 12 & 3,700 \\
\hline B19 & Batteries & 2 & 0.01 & 1,360 \\
\hline Total & & 44,000 & 13 & \\
\hline
\end{tabular}

\section{Hazardous Waste}

\begin{tabular}{|c|l|c|c|c|}
\hline $\begin{array}{c}\text { Waste Stream } \\
\text { Number }\end{array}$ & \multicolumn{1}{|c|}{$\begin{array}{c}\text { Waste Stream } \\
\text { Description }\end{array}$} & $\begin{array}{c}\text { Mass } \\
\mathbf{k g} / \mathbf{y r}\end{array}$ & $\begin{array}{c}\text { Volume } \\
\mathbf{m}^{\mathbf{3}} / \mathbf{y r}\end{array}$ & $\begin{array}{c}\text { Bulk Density } \\
\mathbf{k g} / \mathbf{m}^{\mathbf{3}}\end{array}$ \\
\hline \hline B7 & $\begin{array}{l}\text { Analytical Lab/Rad Con } \\
\text { Chemicals* }\end{array}$ & 476 & 0.5 & 1,000 \\
\hline B8 & $\begin{array}{l}\text { Oxygen Sensor Micro-fuel } \\
\text { Cells }\end{array}$ & 4.5 & 0.004 & 1,700 \\
\hline B19 & Batteries & 500 & 1 & 1,360 \\
\hline Total & & 1,500 & 2 & \\
\hline
\end{tabular}


*Analytical Laboratory/Rad Con chemicals are wastes for which treatments cannot be defined. Treatment will be a function of the type of chemical; e.g., solid, liquid, acid, base, etc. Most chemicals are assumed to be clean non-radioactive waste and can be shipped to an off-site vendor for processing. The numbers shown here are approximate, excluding pump oils and alcohols. A specific gravity of 1 is assumed. 
D. APT Sanitary/Industrial Waste

\begin{tabular}{|c|l|r|r|r|}
\hline $\begin{array}{c}\text { Waste Stream } \\
\text { Number }\end{array}$ & \multicolumn{1}{|c|}{$\begin{array}{c}\text { Waste Stream } \\
\text { Description }\end{array}$} & $\begin{array}{c}\text { Mass } \\
\mathbf{k g} / \mathbf{y r}\end{array}$ & $\begin{array}{c}\text { Volume } \\
\mathbf{m}^{\mathbf{3}} / \mathbf{y r}\end{array}$ & $\begin{array}{c}\text { Bulk } \\
\text { Density } \\
\mathbf{k g} / \mathbf{m}^{\mathbf{3}}\end{array}$ \\
\hline \hline B13 & $\begin{array}{l}\text { Non-Radioactive } \\
\text { Process Wastewater }\end{array}$ & - & $4,800,000$ & 1,000 \\
\hline B14 & $\begin{array}{l}\text { Sanitary and Industrial } \\
\text { Waste (Solid) }\end{array}$ & $6,000,0000$ & 12,000 & 152 \\
\hline B14 & $\begin{array}{l}\text { Sanitary and Industrial } \\
\text { Waste (Liquid) }\end{array}$ & - & 15,500 & 1,000 \\
\hline B19 & Batteries & 50 & 0.1 & 1,360 \\
\hline & Total & $6,000,0000$ & $4,830,000$ & \\
\hline
\end{tabular}

E. APT Air Emissions

\begin{tabular}{|c|l|c|}
\hline $\begin{array}{c}\text { Waste Stream } \\
\text { Number }\end{array}$ & \multicolumn{1}{|c|}{$\begin{array}{c}\text { Waste Stream } \\
\text { Description }\end{array}$} & $\begin{array}{c}\text { Mass } \\
\mathbf{k g} / \mathbf{y r}\end{array}$ \\
\hline \hline B20 & $\begin{array}{l}\text { Non-Radioactive Air } \\
\text { Emissions }\end{array}$ & 16,000 \\
\hline B21 & $\begin{array}{l}\text { Radioactive Air } \\
\text { Emissions }\end{array}$ & TBD \\
\hline \hline & Total & $\mathbf{1 6 , 0 0 0 +}$ \\
\hline
\end{tabular}




\section{APPENDIX G}

\section{EPA Hazardous Waste Codes With Subcategories}

Table Gl below lists EPA hazardous waste codes for which EPA has developed subcategories (40 CFR sections 268.41 through 268.43, Tables CCWE, 2, 3, and CCW). For each subcategory, DOE has assigned a letter subcode. The subcategories represent unique Land Disposal Restrictions (LDR) treatability groups with distinct treatment standards. In addition, DOE has assigned a subcategory (with subcode " $X$ ") for wastes that, because of a lack of characterization information, could not be put into an appropriate EPA defined subcategory. This table was developed in support of the SRS Approved Site Treatment Plan for mixed waste, WSRC-TR-940608, the table has been modified by the APT Waste Management Team to delete waste categories not generated by the APT, and is subject to change. 
Table G1

\section{EPA Hazardous Waste Codes with Subcategories defined under the LDRs Program}

\begin{tabular}{|c|c|c|c|c|}
\hline $\begin{array}{l}\text { EPA } \\
\text { Code }\end{array}$ & $\begin{array}{l}\text { Sub } \\
\text { code }\end{array}$ & Subcategory & Conc Limit & Description \\
\hline \multirow[t]{2}{*}{ D001 } & A & $\begin{array}{l}\text { Ignitable Liquids High TOC } \\
\text { Nomwastewaters }\end{array}$ & & $\begin{array}{l}\text { Ignitable liquids as defined in } 40 \mathrm{CFR} \\
261.21 \text { containing } 10 \% \text { or greater Total } \\
\text { Organic Carbon (TOC). }\end{array}$ \\
\hline & $\mathrm{C}$ & $\begin{array}{l}\text { Ignitable Waste, Low TOC } \\
\text { Nonwastewaters }\end{array}$ & & $\begin{array}{l}\text { All other ignitable waste as identified in } \\
40 \text { CFR } 261.21 \text { that is neither a high } \\
\text { TOC nor managed as wastewater. }\end{array}$ \\
\hline \multirow[t]{2}{*}{ D002 } & $\bar{A}$ & $\begin{array}{l}\text { Corrosive Wastewater-Acid, } \\
\text { Alkaline or Other }\end{array}$ & & $\begin{array}{l}\text { Corrosive waste, as identified in } 40 \text { CFR } \\
261.22 \text {, managed as wastewater. [e.g., in } \\
\text { Clean Water Act surface impoundments } \\
\text { or land disposed units (or their } \\
\text { equivalent); or in Safe Drinking Water } \\
\text { Act underground injection wells.] }\end{array}$ \\
\hline & $\bar{B}$ & $\begin{array}{l}\text { Corrosive Nonwastewater-Acid, } \\
\text { Alkaline or Other }\end{array}$ & & $\begin{array}{l}\text { Corrosive waste, as identified in } 40 \text { CFR } \\
261.22 \text {, not managed as wastewater. }\end{array}$ \\
\hline \multirow[t]{2}{*}{ D003 } & $\bar{A}$ & Reactive Cyanides & & $\begin{array}{l}\text { Cyanide-bearing wastes that, when } \\
\text { exposed to } \mathrm{pH} \text { conditions between } 2 \text { and } \\
12.5 \text {, generate hazardous quantities of } \\
\text { toxic gases. }\end{array}$ \\
\hline & $\bar{B}$ & Reactive Sulfides & & $\begin{array}{l}\text { Sulfide-bearing wastes that, when } \\
\text { exposed to pH conditions between } 2 \text { and } \\
12.5 \text {, generate hazardous quantities of } \\
\text { toxic gases. }\end{array}$ \\
\hline
\end{tabular}




\section{Table GI}

\section{EPA Hazardous Waste Codes with Subcategories defined under the LDRs Program (Cont'd)}

\begin{tabular}{|c|c|c|c|c|}
\hline $\begin{array}{l}\text { EPA } \\
\text { Code }\end{array}$ & $\begin{array}{l}\text { Sub } \\
\text { code }\end{array}$ & Subcategory & Conc Limit & Description \\
\hline & $\mathbf{C}$ & Explosives & & $\begin{array}{l}\text { Waste capable of detonation or explosive } \\
\text { reaction under various conditions, or is a } \\
\text { forbidden, Class A or Class B explosive } \\
\text { under DOT regulations. }\end{array}$ \\
\hline & D & Water Reactives & & $\begin{array}{l}\text { Waste, as defined in } 40 \text { CFR } 261.23(a)(2) \text {, } \\
\text { (3), or (4), that is either very reactive with } \\
\text { water, or is capable of generating toxic or } \\
\text { explosive gases with water. }\end{array}$ \\
\hline & $\bar{E}$ & Other Reactives & & $\begin{array}{l}\text { Reactive waste that, per } 40 \text { CFR } \\
261.23(a)(1) \text {, is nomally unstable and } \\
\text { readily under goes violent change without } \\
\text { detonating. }\end{array}$ \\
\hline D004 & $\bar{A}$ & TCLP Toxic for Arsenic & $5.0 \mathrm{mg} / \mathrm{l}$ & $\begin{array}{l}\text { Those wastes that exhibit the toxicity } \\
\text { characteristics for arsenic. }\end{array}$ \\
\hline $\mathrm{D} 005$ & $\bar{A}$ & TCLP Toxic for Barium & $100 \mathrm{mg} / 1$ & $\begin{array}{l}\text { Those wastes that exhibit the toxicity } \\
\text { characteristics for barium. }\end{array}$ \\
\hline D006 & $\bar{A}$ & TCLP Toxic for Cadmium & $1.0 \mathrm{mg} / \mathrm{l}$ & $\begin{array}{l}\text { Those wastes that exhibit the toxicity } \\
\text { characteristic for cadmium. }\end{array}$ \\
\hline D006 & $\overline{\mathrm{B}}$ & Cadmium-containing batteries & & $\begin{array}{l}\text { Batteries containing leachable levels of } \\
\text { cadmium above } 1.0 \mathrm{mg} / \text { liter. }\end{array}$ \\
\hline D007 & $\bar{A}$ & TCLP Toxic for Chromium & $5.0 \mathrm{mg} /$ & $\begin{array}{l}\text { Those wastes that exhibit the toxicity } \\
\text { characteristic for cadmium. }\end{array}$ \\
\hline \multirow[t]{3}{*}{$\overline{\mathrm{D} 008}$} & $\bar{A}$ & TCLP Toxic for Lead & $5.0 \mathrm{mg} / 1$ & $\begin{array}{l}\text { Those wastes that exhibit the toxicity } \\
\text { characteristic for lead. }\end{array}$ \\
\hline & B & Lead Acid Batteries & & $\begin{array}{l}\text { Lead acid batteries that are identified as } \\
\text { RCRA hazardous wastes and which are not } \\
\text { excluded from regulation under the land } \\
\text { disposal restrictions. }\end{array}$ \\
\hline & $\bar{C}$ & Radioactive Lead Solids & & $\begin{array}{l}\text { Lead solids, including elemental forms of } \\
\text { lead, but not including treatment residuals } \\
\text { that can be stabilized or organo-lead } \\
\text { materials that can be incinerated (then } \\
\text { stabilized as ash). }\end{array}$ \\
\hline D009 & $\bar{A}$ & TCLP Toxic for Mercury & $0.2 \mathrm{mg} / \mathrm{l}$ & $\begin{array}{l}\text { Nonwastewaters that exhibit the toxicity } \\
\text { characteristic for mercury and contain less } \\
\text { than } 260 \mathrm{mg} / \mathrm{kg} \text { total mercury. }\end{array}$ \\
\hline
\end{tabular}


Table GI

EPA Hazardous Waste Codes with Subcategories defined under the LDRs Program (Cont'd)

\begin{tabular}{|c|c|c|c|c|}
\hline $\begin{array}{l}\text { EPA } \\
\text { Code }\end{array}$ & $\begin{array}{l}\text { Sub } \\
\text { code }\end{array}$ & Subcategory & Conc Limit & $\begin{array}{c}\text { Description } \\
\gamma\end{array}$ \\
\hline \multirow[t]{3}{*}{ D009 } & $\overline{\mathrm{C}}$ & $\begin{array}{l}\text { High Mercury (Contains } \\
\text { Inorganics) }\end{array}$ & & $\begin{array}{l}\text { Nonwastewaters that exhibit the } \\
\text { toxicity characteristic for mercury, } \\
\text { contain greater than or equal to } 260 \\
\text { mg/kg total mercury, are inorganic, } \\
\text { and may include incinerator residues } \\
\text { and residues from mercury roasting } \\
\text { and retorting (RMERC) operations. }\end{array}$ \\
\hline & $\bar{E}$ & $\begin{array}{l}\text { Hydraulic Oil Contaminated with } \\
\text { Mercury Radioactive Materials }\end{array}$ & & $\begin{array}{l}\text { Hydraulic oil exhibiting the toxicity } \\
\text { characteristic for mercury and which } \\
\text { is contaminated with radioactive } \\
\text { materials. }\end{array}$ \\
\hline & $\bar{X}$ & $\begin{array}{l}\text { Nonwastewater with Unknown } \\
\text { Mercury Concentration }\end{array}$ & & $\begin{array}{l}\text { Characteristically hazardous mixed } \\
\text { wastes due to mercury that are not } \\
\text { elementary mercury, hydraulic oil or } \\
\text { high-level waste, for which it is not } \\
\text { known if the mercury concentration is } \\
\text { less than or equal to } 260 \mathrm{ppm} \text {. }\end{array}$ \\
\hline \multirow{2}{*}{$\begin{array}{l}\text { D010 } \\
\text { D011 }\end{array}$} & A & TCLP Toxic for Selenium & $5.7 \mathrm{mg} / \mathrm{l}$ & $\begin{array}{l}\text { Those wastes that exhibit the toxicity } \\
\text { characteristics for selenium. }\end{array}$ \\
\hline & $\bar{A}$ & TCLP Toxic for Silver & $5.0 \mathrm{mg} / 1$ & $\begin{array}{l}\text { Those wastes that exhibit the toxicity } \\
\text { characteristics for silver. }\end{array}$ \\
\hline \multirow[t]{2}{*}{ F003 } & A & Spent Nonhalogenated Solvents & $\begin{array}{l}2.6-180 \\
\mathrm{mg} / 1\end{array}$ & $\begin{array}{l}\text { F003 solvent due to the presence of } \\
\text { one of the following: acetone, ethyl } \\
\text { acetate, ethyl benzene, ethyl ether, } \\
\text { methyl isobutyl ketone, n-Butyl } \\
\text { alcohol, and xylene. Also } \\
\text { cyclohexane, but only if F001-F005 } \\
\text { solvents other than methanol and/or } \\
\text { carbon disulfide (F005) are also } \\
\text { present. Also methanol, but only if } \\
\text { F001-F005 solvents other than } \\
\text { cyclohexane and/or carbon disulfide } \\
\text { (F005) are also present. }\end{array}$ \\
\hline & $\bar{B}$ & $\begin{array}{l}\text { Cyclohexane/Methanol/Carbon } \\
\text { Disulfide Only }\end{array}$ & & $\begin{array}{l}\text { F003 solvent due to the presence of } \\
\text { cyclohexane, methanol or carbon } \\
\text { disulfide, but only if no other F001- } \\
\text { F005 solvents are present (except } \\
\text { cyclohexane, methanol and/or carbon } \\
\text { disulfide are also present). }\end{array}$ \\
\hline
\end{tabular}




\section{Table G1}

\section{EPA Hazardous Waste Codes with Subcategories defined under the LDRs Program (Cont'd)}

\begin{tabular}{|c|c|c|c|c|}
\hline $\begin{array}{l}\text { EPA } \\
\text { Code }\end{array}$ & $\begin{array}{l}\text { Sub } \\
\text { code }\end{array}$ & Subcategory & Conc Limit & Description \\
\hline \multirow[t]{4}{*}{ F005 } & $\bar{A}$ & Spent Nonhalogenated Solvents & $\begin{array}{c}10-170 \\
\mathrm{mg} /\end{array}$ & $\begin{array}{l}\text { The following spent non-halogenated } \\
\text { solvents: benzene, isobutanol, } \\
\text { methylethyl ketone, pyridine, and } \\
\text { toluene. Also, carbon disulfide if F001- } \\
\text { F005 solvents other than cyclohexane } \\
\text { (F003) and/or methanol (F003) are also } \\
\text { present. Also, 2-Ethoxyethanol and 2- } \\
\text { Nitropropane, but only if other F001- } \\
\text { F005 solvents are also present. }\end{array}$ \\
\hline & B & $\begin{array}{l}\text { Solvent Waste Listed for 2- } \\
\text { Nitropropane only }\end{array}$ & & $\begin{array}{l}\text { Waste containing 2-nitropropane as the } \\
\text { only F001-F005 listed solvent. }\end{array}$ \\
\hline & $\mathrm{C}$ & $\begin{array}{l}\text { Solvent Waste Listed for 2- } \\
\text { Ethoxyethanol only }\end{array}$ & & $\begin{array}{l}\text { Waste containing } 2 \text {-ethoxyethanol as the } \\
\text { only F001-F005 listed solvent. }\end{array}$ \\
\hline & $\mathrm{D}$ & $\begin{array}{l}\text { Cyclohexane/Methanol/Carbon } \\
\text { Disulfide only }\end{array}$ & & $\begin{array}{l}\text { F005 listed mixed waste for which the } \\
\text { specific F005 constituent is not } \\
\text { identified. } \\
\text { F005 solvent due to the presence of } \\
\text { carbon disulfide, but only if no other } \\
\text { F001-F005 solvents are present, except } \\
\text { that cyclohexane (F003) and/or methanol } \\
\text { (F003) may also be present. }\end{array}$ \\
\hline F025 & $\bar{A}$ & F025 Light Ends & & $\begin{array}{l}\text { Light ends listed for one or more of the } \\
\text { following: Carbon Tetrachloride; } \\
\text { chloroform; 1, 2-Dichloroethane; 1, 1- } \\
\text { Dichloroethylene; methylene chloride; } 1 \text {, } \\
\text { 1, 2-Trichloroethane; Trichloethane or } \\
\text { vinyl chloride; plus wastes qualifying as } \\
\text { F025 light ends, but characterization } \\
\text { information is insufficient to determine } \\
\text { specific contaminants. }\end{array}$ \\
\hline
\end{tabular}




\section{Table G1}

\section{EPA Hazardous Waste Codes with Subcategories defined under the LDRs Program (Cont'd)}

\begin{tabular}{|c|c|c|c|c|}
\hline $\begin{array}{l}\text { EPA } \\
\text { Code }\end{array}$ & $\begin{array}{l}\text { Sub } \\
\text { code }\end{array}$ & Subcategory & Conc Limit & Description \\
\hline & $\overline{\mathrm{B}}$ & Spent Filter/Aids and Desiccants & & $\begin{array}{l}\text { Spent filters/aids comtaining one or } \\
\text { more of the following: Carbon } \\
\text { tetrachloride, chloroform, methylene } \\
\text { chloride, 1, 1, 2-Trichloroethane, } \\
\text { Trichloroethylene, vinyl chloride, } \\
\text { hexachlorobutadiene, or } \\
\text { hexachloroethane, plus wastes } \\
\text { qualifying as F025 spent filters/aids or } \\
\text { desiccants, but characterization is } \\
\text { insufficient to determine specific } \\
\text { contaminants. }\end{array}$ \\
\hline \multirow[t]{2}{*}{ P047 } & $\bar{A}$ & 4, 6-Dinitro-o-cresol & & $\begin{array}{l}\text { 4,6-Dinitro-o-cresol as a discarded } \\
\text { commercial chemical product, off- } \\
\text { specification species, container } \\
\text { residue, or spill residue. }\end{array}$ \\
\hline & B & 4, 6-Dinitro-o-cresol salts & & $\begin{array}{l}\text { 4, 6-Dinitro-o-cresol salts as discarded } \\
\text { commercial chemical products, off- } \\
\text { specification species, container } \\
\text { residues, or spill residues. }\end{array}$ \\
\hline \multirow[t]{2}{*}{ P059 } & A & Heptachlor & & $\begin{array}{l}\text { Heptachlor as a discarded commercial } \\
\text { chemical product, off-specification } \\
\text { species, container residue, or spill } \\
\text { residue. }\end{array}$ \\
\hline & $\mathrm{B}$ & Heptachlor Epoxide & & $\begin{array}{l}\text { Heptachlor epoxide as a discarded } \\
\text { commercial chemical product, off- } \\
\text { specification species, container } \\
\text { residue, or spill residue. }\end{array}$ \\
\hline
\end{tabular}


Table G1

EPA Hazardous Waste Codes with Subcategories defined under the LDRs Program (Cont'd)

\begin{tabular}{|c|c|l|c|l|}
\hline $\begin{array}{c}\text { EPA } \\
\text { Code }\end{array}$ & $\begin{array}{l}\text { Sub } \\
\text { code }\end{array}$ & \multicolumn{1}{|c|}{ Subcategory } & Conc Limit & \multicolumn{1}{|c|}{ Description } \\
\hline \hline P092 & A & $\begin{array}{l}\text { Phenyl Mercury Acetate } \\
\text { Nonwastewater } \\
\text { High Mercury Incinerator or } \\
\text { RMERC Residues }\end{array}$ & & $\begin{array}{l}\text { Nonwastewaters phenyl mercury } \\
\text { acetate wastes, regardless of mercury } \\
\text { content, that are residues from either } \\
\text { incineration or mercury roasting or } \\
\text { retorting (RMERC) of wastes } \\
\text { containing phenyl mercury acetate. }\end{array}$ \\
\cline { 2 - 5 } & B & $\begin{array}{l}\text { Phenyl Mercury Acetate } \\
\text { Nonwastewater } \\
\text { Phenyl Mercury Acetate Waste } \\
\text { (not from incineration or } \\
\text { RMERC) }\end{array}$ & $\begin{array}{l}\text { Nonwastewaters phenyl mercury } \\
\text { acetate wastes, regardless of mercury } \\
\text { content, that are residues from } \\
\text { incineration nor residues from } \\
\text { RMERC. }\end{array}$ \\
\cline { 2 - 5 } & C & $\begin{array}{l}\text { Phenyl Mercury Acetate } \\
\text { Nonwastewater } \\
\text { Low Mercury RMERC Residues }\end{array}$ & $\begin{array}{l}\text { Nomwastewaters with less than 260 } \\
\text { mg/kg total mercury and that are } \\
\text { residues from RMERC of wastes } \\
\text { containing phenyl mercury acetate. }\end{array}$ \\
\hline
\end{tabular}




\section{Table G1}

\section{EPA Hazardous Waste Codes with Subcategories defined under the LDRs Program (Cont'd)}

\begin{tabular}{|c|c|l|l|l|}
\hline $\begin{array}{c}\text { EPA } \\
\text { Code }\end{array}$ & $\begin{array}{l}\text { Sub } \\
\text { code }\end{array}$ & \multicolumn{1}{|c|}{ Subcategory } & Conc Limit & \multicolumn{1}{|c|}{ Description } \\
\hline U151 & A & High Mercury Nonwastewater & & $\begin{array}{l}\text { Nomwastewaters with greater than or } \\
\text { equal to 260 mg/kg total mercury } \\
\text { [including residues from mercury } \\
\text { roasting or retorting (RMERC) of } \\
\text { U151 waste if it contains greater than } \\
\text { or equal to 260 mg/kg total mercuryl }\end{array}$ \\
\hline B & $\begin{array}{l}\text { Low Mercury Nonwastewaters } \\
\text { from RMERC }\end{array}$ & $\begin{array}{l}\text { Nonwastewaters with less than 260 } \\
\text { mg/kg total mercury and that are } \\
\text { residues from RMERC of U151 } \\
\text { wastes. }\end{array}$ \\
\hline C & Low Mercury Nonwastewaters & $\begin{array}{l}\text { Nonwastewaters with less than 260 } \\
\text { mg/kg total mercury that are not } \\
\text { residues from RMERC. }\end{array}$ \\
\hline E & Mercury Wastewaters & $\begin{array}{l}\text { All U151 (mercury) waste managed as } \\
\text { wastewaters. }\end{array}$ \\
\hline A & $\begin{array}{l}\text { 2,4-D (also known as } \\
\text { Dichlorophenoxyacetic Acid) }\end{array}$ & $\begin{array}{l}\text { 2,4-D as a discarded commercial } \\
\text { chemical product, off-specification } \\
\text { species, container residues, or spill } \\
\text { residues. }\end{array}$ \\
\hline B & $\begin{array}{l}\text { 2,4-D (Dichlorophenoxyacetic } \\
\text { Acids) Salts \& Esters }\end{array}$ & $\begin{array}{l}\text { 2,4-D salts or esters as discarded } \\
\text { commercial chemical products, off- } \\
\text { specification species, container } \\
\text { residues, or spill residues. }\end{array}$ \\
\hline & C & $\begin{array}{l}\text { U240 waste, but characterization } \\
\text { information is insufficient to } \\
\text { determine whether the A or B subcode } \\
\text { is appropriate. }\end{array}$ \\
\hline
\end{tabular}




\section{APPENDIX H}

\section{APT Decommissioning and Construction Wastes}

The APT Waste Management Team developed the decommissioning waste estimates in support of the APT CDR of April 1997 (Reference 36). The decommissioning estimates used WMin/PP principles in looking at each facility for reuse, modification, or future use (see Table H1). Waste estimates (see Table H2) of facilities to be decommissioned were then based on facility size and expected use (radiological, industrial, office, etc.).

BREI developed the construction waste estimates in support of the site specific APT EIS. The numbers were converted to metric and rounded from the original source data (Reference 38 ) for inclusion into the PPDA. 


\section{Table H1}

\section{APT Facility Contamination Index and Decommissioning Disposition}

\begin{tabular}{|c|c|c|c|c|c|c|c|}
\hline Burding & $\begin{array}{l}\text { Red } \\
\text { Contam'd }\end{array}$ & $\begin{array}{l}\text { Enazandowe } \\
\text { Contam'd }\end{array}$ & $\begin{array}{l}\text { Remove } \\
\text { Recyclable } \\
\text { Salvage } \\
\text { Material } \\
\end{array}$ & $\begin{array}{l}\text { Leave } \\
\text { Structure } \\
\text { In Place }\end{array}$ & $\begin{array}{l}\text { Remove } \\
\text { Contamimation }\end{array}$ & Demollish & Avallable \\
\hline INJECTOR & & NO & $x$ & & & $\mathbf{x}$ & \\
\hline Accelerator LE & NO & NO & $x$ & $\mathrm{X}$ & & & $\begin{array}{l}\text { X } \\
\text { STORAGE } \\
\text { STTE } \\
\end{array}$ \\
\hline Accelerator HE & YES & NO & $\bar{x}$ & $\bar{x}$ & $\bar{x}$ & & $\begin{array}{l}\mathrm{X} \\
\text { STORAGE } \\
\text { SITE }\end{array}$ \\
\hline HEBT & YES & NO & & & $\mathrm{X}$ & $x$ & \\
\hline $\begin{array}{l}\text { KLYSTRON } \\
\text { GALLERY }\end{array}$ & NO & NO & & $\bar{x}$ & & & $\begin{array}{l}\mathrm{X} \\
\text { INDUSTRLAL } \\
\text { REUSE }\end{array}$ \\
\hline T/B & YES & YES & $\bar{x}$ & $\begin{array}{l}\text { X(SOME } \\
\text { BELOW } \\
\text { GRADE) }\end{array}$ & $\bar{x}$ & $\begin{array}{l}\text { X(MOST } \\
\text { OF THE } \\
\text { FACILITY) } \\
\end{array}$ & \\
\hline BEAM STOP & YES & $\bar{N}$ & $\bar{X}$ & & $x$ & $\bar{x}$ & \\
\hline CRYOGENIC & NO & NO & $\bar{x}$ & $\bar{x}$ & & & $\begin{array}{l}\mathrm{X} \\
\text { INDUSTRIAL } \\
\text { REUSE } \\
\end{array}$ \\
\hline $\begin{array}{l}\text { KLYSTRON } \\
\text { REMANUFACTURIN } \\
\text { G FACILITY }\end{array}$ & NO & YES & $X$ & $\bar{x}$ & & & $\begin{array}{l}\mathrm{X} \\
\text { INDUSTRIAL } \\
\text { REUSE } \\
\end{array}$ \\
\hline $\begin{array}{l}\text { MECHANICAL } \\
\text { SERVICE }\end{array}$ & YES & YES & $\mathrm{X}$ & & & $\bar{X}$ & \\
\hline OPERATIONS & NO & NO & $\bar{x}$ & & & & $\begin{array}{l}\mathrm{X} \\
\text { OFFICE SPACE }\end{array}$ \\
\hline$\overline{\text { TSF }}$ & YES & YES & $\bar{x}$ & & $\bar{x}$ & $\bar{x}$ & \\
\hline ACCESS CONTROL & NO & No & & & & $\bar{x}$ & \\
\hline SOLID RADWASTE & YES & YES & $\mathrm{x}$ & & & . & $\begin{array}{l}\mathbf{X} \\
\text { RADWASTE } \\
\text { TREATMENT/ } \\
\text { STORAGE } \\
\text { FACILITY }\end{array}$ \\
\hline BACKUP POWER & No & YES & $\mathrm{X}$ & & $\mathrm{X}$ & $\bar{x}$ & \\
\hline MAINTENANCE & YES & YES & $\mathrm{X}$ & & $\mathrm{X}$ & & $\begin{array}{l}\mathrm{X} \\
\text { INDUSTRIAL } \\
\text { REUSE }\end{array}$ \\
\hline WAREHOUSE & NO & NO & $\mathrm{X}$ & & & & $\begin{array}{l}\mathrm{X} \\
\text { INDUSTRIAL } \\
\text { REUSE }\end{array}$ \\
\hline ADMINISTRATION & NO & NO & $\bar{X}$ & & & & $\begin{array}{l}X \\
\text { OFFICE SPACE }\end{array}$ \\
\hline SIMULATOR & NO & NO & $\bar{X}$ & & & & $\begin{array}{l}\mathrm{X} \\
\text { TRAINING } \\
\text { CENTER }\end{array}$ \\
\hline SECURITY & No & NO & $\bar{x}$ & & & $\bar{x}$ & \\
\hline $\begin{array}{l}\text { T/B SECONDARY } \\
\text { HEAT }\end{array}$ & YES & No & $\bar{x}$ & & $\bar{X}$ & $\bar{X}$ & \\
\hline $\begin{array}{l}\text { BEAM STOP } \\
\text { SECONDARY HEAT }\end{array}$ & YES & NO & $\bar{x}$ & & $\bar{x}$ & $\bar{x}$ & \\
\hline
\end{tabular}




\section{Table H1 - Cont'd}

\section{APT Facility Contamination Index and Decommissioning Disposition}

\begin{tabular}{|c|c|c|c|c|c|c|c|}
\hline Buidting & $\begin{array}{l}\text { Rad } \\
\text { Contam'd }\end{array}$ & $\begin{array}{l}\text { Hezardous } \\
\text { Contam'd }\end{array}$ & $\begin{array}{l}\text { Remove } \\
\text { Recyclable } \\
\text { Salvage } \\
\text { Material }\end{array}$ & $\begin{array}{l}\text { Lenve } \\
\text { Structure } \\
\text { In Place }\end{array}$ & $\begin{array}{l}\text { Remove } \\
\text { Contamination }\end{array}$ & Demoliah & Avallable \\
\hline $\begin{array}{l}\text { WASTE WATER } \\
\text { PUMPING }\end{array}$ & NO & NO & $\mathrm{x}$ & & & & $\begin{array}{l}X \\
\text { SUPPORT } \\
\text { INDUSTRIAL } \\
\text { SITE } \\
\end{array}$ \\
\hline DEMINERALIZER & No & No & $\mathrm{X}$ & & & $\bar{x}$ & \\
\hline $\begin{array}{l}\text { PRIMARY } \\
\text { SUBSTATION }\end{array}$ & NO & YES (?) & $\mathrm{X}$ & & & & $\begin{array}{l}\text { X } \\
\text { SUPPORT } \\
\text { INDUSTRIAL } \\
\text { SIIE } \\
\end{array}$ \\
\hline SWITCHYARD & NO & YES (?) & $\mathrm{X}$ & & & $\underline{X}$ & \\
\hline $\begin{array}{l}\text { KLYSTRON } \\
\text { ELECTRICAL } \\
\text { EQUIPMENT } \\
\end{array}$ & No & NO & $\mathbf{X}$ & & & $\mathbf{x}$ & \\
\hline $\begin{array}{l}\text { T/B ELECTRICAL } \\
\text { EQUIPMENT }\end{array}$ & No & NO & $\mathbf{X}$ & & & $\bar{x}$ & \\
\hline $\begin{array}{l}\text { HEBT ELECTRICAL } \\
\text { EQUIPMENT }\end{array}$ & NO & No & $\bar{x}$ & & & $\bar{x}$ & \\
\hline $\begin{array}{l}\text { TRANSFORMER } \\
\text { RECTIFIER }\end{array}$ & NO & No & 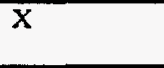 & & & $\mathrm{X}$ & \\
\hline WATER TANK & NO & No & $x$ & & & $x$ & \\
\hline FIRE PROTECTION & NO & NO & $\bar{x}$ & & & & $\begin{array}{l}X \\
\text { SUPPORT } \\
\text { INDUSTRIAL } \\
\text { SITE } \\
\end{array}$ \\
\hline KLYSTRON TOWERS & NO & NO & $\bar{x}$ & & & $\bar{x}$ & \\
\hline CRYOTOWERS & NO & No & $X$ & & & $X$ & \\
\hline BEAM STOP TOWERS & NO & NO & $\bar{x}$ & & & $\bar{X}$ & \\
\hline T/B TOWERS & YES & No & $\mathrm{x}$ & & $\bar{x}$ & $\bar{X}$ & \\
\hline $\begin{array}{l}\text { KLYSTRON } \\
\text { REMANUFACTURNN } \\
\text { GTOWERS } \\
\end{array}$ & No & No & $\mathrm{X}$ & & & $\bar{x}$ & \\
\hline $\begin{array}{l}\text { CAVITY FLOOD } \\
\text { TANK }\end{array}$ & YES & $\overline{\text { YES }}$ & $\bar{x}$ & & $\bar{x}$ & $\bar{x}$ & \\
\hline $\begin{array}{l}\text { HVAC EXHAUST } \\
\text { FILTER }\end{array}$ & YES & YES & $\bar{X}$ & & $\overline{\mathrm{X}}$ & $\bar{x}$ & \\
\hline CRYO TANKS & NO & No & $\bar{X}$ & & & $\mathrm{X}$ & \\
\hline
\end{tabular}




\section{Table H2}

\section{Facility and Infrastructure Decommissioning Waste Quantities Waste Volume is in $\mathbf{M}^{3}$}

\begin{tabular}{|c|c|c|c|c|c|c|c|}
\hline Builing & LLRW & Bak LLRW & $\begin{array}{l}\text { Recyclable } \\
\text { Solvage } \\
\text { Material }\end{array}$ & Hezardow & MLLW & Rubble & $\begin{array}{l}\text { Seniterg/ } \\
\text { Industrial }\end{array}$ \\
\hline INJECTOR & 400 & 1,800 & 360 & 0 & 0 & 200 & 10 \\
\hline HEBT & 2,800 & 6,000 & 0 & 0 & 0 & 1,000 & 10 \\
\hline $\mathbf{T} / \mathbf{B}$ & 10,000 & 40,000 & 20,000 & 10 & 120 & 10,000 & 1,000 \\
\hline BEAM STOP & 4,000 & 8,400 & 160 & 0 & 0 & 100 & 10 \\
\hline $\begin{array}{l}\text { MECHANICAL } \\
\text { SERVICE }\end{array}$ & 1,000 & 2,000 & 2,000 & 10 & 10 & 4,000 & 1.980 \\
\hline TSF & 4,000 & 16,000 & 100 & 30 & 60 & 1,500 & 200 \\
\hline ACCESS OONTROL & 0 & 0 & 0 & 0 & 0 & 690 & 160 \\
\hline BACKUP POWER & 0 & 0 & 150 & 0 & 0 & 100 & 50 \\
\hline SECURITY & 0 & 0 & 0 & 0 & 0 & 800 & 80 \\
\hline $\begin{array}{l}\text { T/B SECONDARY } \\
\text { HEAT }\end{array}$ & 880 & 1,320 & 460 & 0 & 0 & 800 & 80 \\
\hline $\begin{array}{l}\text { BEAM STOP } \\
\text { SECONDARY HEAT }\end{array}$ & 90 & 130 & 50 & 0 & 0 & 80 & 10 \\
\hline DEMINERALIZER & 0 & 0 & 160 & 0 & 0 & 700 & 200 \\
\hline $\begin{array}{l}\text { PRMMARY } \\
\text { SUBSTATIONS }\end{array}$ & $\overline{0}$ & 0 & 700 & 50 & 0 & 1,200 & 300 \\
\hline $\begin{array}{l}\text { KLYSTRON } \\
\text { ELECTRICAL } \\
\text { EQUIPMENT }\end{array}$ & 0 & 0 & 110 & 0 & 0 & 300 & 280 \\
\hline $\begin{array}{l}\text { T/B ELECTRICAL } \\
\text { EQUIPMENT }\end{array}$ & 0 & 0 & 20 & $\overline{0}$ & 0 & 60 & So \\
\hline $\begin{array}{l}\text { HEBT ELECTRICAL } \\
\text { EQUIPMENT }\end{array}$ & 0 & 0 & $\overline{20}$ & 0 & 0 & 60 & So \\
\hline $\begin{array}{l}\text { TRANSFORMER } \\
\text { RECTIFIER }\end{array}$ & 0 & 0 & 230 & 0 & 0 & 1,000 & 310 \\
\hline WATER TANK & 0 & 0 & 20 & 0 & 0 & 100 & 40 \\
\hline KLYSTRON TOWERS & 0 & 0 & 810 & 0 & 0 & 2700 & 1530 \\
\hline CRYO TOWERS & 0 & 0 & 270 & 0 & 0 & 900 & 510 \\
\hline BEAM STOP TOWERS & 0 & 0 & 90 & 0 & 0 & 300 & 170 \\
\hline T/B TOWERS & & & 180 & 0 & 0 & 600 & 340 \\
\hline $\begin{array}{l}\text { KLYSTRON } \\
\text { REMANUFACTURING } \\
\text { TOWERS }\end{array}$ & 0 & 0 & 90 & 0 & 0 & 300 & 170 \\
\hline $\begin{array}{l}\text { CAVITY FLOOD } \\
\text { TANK }\end{array}$ & 40 & 100 & 0 & 0 & 10 & 20 & 10 \\
\hline $\begin{array}{l}\text { HVAC EXHAUST } \\
\text { FILTER }\end{array}$ & 100 & 600 & 0 & 0 & 10 & 100 & 30 \\
\hline CRYO TANKS & 0 & 0 & 1,800 & 0 & 0 & 9,000 & 950 \\
\hline TOTAL & 23,310 & 76,410 & 27,690 & 100 & 210 & 36,610 & 8,530 \\
\hline
\end{tabular}




\section{Decommissioning Assumptions}

1. Facility floor area and general characterization information from the APT CDR were used to determine the waste estimates.

2. Process sewe line removal and remediation is an ER responsibility.

3. All facilities will be in a safe storage condition prior to Decommissioning (i.e, all nuclear fuel or liquid waste will have been removed, sy stems flushed and drained). All APT liquids are removed and processed as final part of $0 \& M$

4. All surplus chemicals (including fuel/ubricants) stored in facilities will be drained/removed prior to Decommissioning and therefore, are not included in this estimate.

5. Residual chemicals are considered to be RCRA hazardous.

6. Salvage/reuse of equipment was considered only for selected facilities. Salvageable equipment volume was estimated at $15 \%$ of the total possible waste volume if process knowledge did not allow another volume to be used

7. Volume reduction (induding compaction and treatment) and recycle are not considered in this estimate.

8. For radiological facilities, the estimate includes removal of 2 feet of soil beneath the facility slab, only if the facility is completely Decommissioned. Of the removed soil $15 \%$ is assumed to be low level radioactive waste. The remaining $85 \%$ is assumed to free of any contamination (radological and hazardous) and suitable for backfill.

9. For facilities with storage tanks (either above ground or below), the estimate includes mina to moderate soil removal. Removed soil from a nonradiological facility is assumed to be hazardous waste.

10. No recycle of non-radioactive concrete rubble is considered.

11. Waste volume estimates were rounded to the nearest 10.

12. Groundwater remediation is not considered in this estimate.

13. All Cavity Vessel Modules are removed and processed as final part of O\&M.

14. $10 \%$ of the total waste estimate is incinerable waste. 
15. Facilities not listed above are left in place for reuse or use as disposal locations.

16. The tunnel will be used for non-radioactive rubble waste disposal.

17. Nonradiologically contaminated (clean) administrative faclities (offices, guardshacks, etc.) are empty facilities, i.e, all furniture, partitions, computers, office supplies, etc. have been removed.

18. The subgrade portion of the T/B Facility will be left in place for Bulk LLRW disposal.

19. Empty administrative space (with foundation) will generate $6 \mathrm{ft}^{3}$ of Decommissioning waste per $\mathrm{ft}^{2}$ of floor area

20. Empty, nonradiologically contaminated (clean) storage warehouses ( $>15$ foot ceifings) will generate $8 \mathrm{ft}^{3}$ of Decommissioning waste per $\mathrm{ft}^{2}$ of floor area

21. Process/production facilities and their support facilities will generate $12 \mathrm{ft}^{3}$ of Decommissioning waste per $\mathrm{ft}^{2}$ of floor area

22. Identification of waste categories generated is based on the APT CDR and PPDA APpendix

B information

24. All pre-Decommissioning activities generating waste by facility operations are not included in this waste estimate.

25. Lowest cost surveillance and maintenance (S\&M) will include additional removal of hazardous and radioactive materials as part of reducing S\&M hazards and costs. Limited facility dismantlement may also be accomplished to reduce S\&M costs and reduce occup ational risk.

26. Decommissioning work will be driven by the available funding amounts. This report assumes funding will be available in the year the facility is forecast for Decommissioning 
Table $\mathbf{H 3}$

\section{APT Construction Wastes}

Waste Volume is in $\mathbf{M}^{3}$

\begin{tabular}{|l|r|r|}
\hline \multicolumn{1}{|c|}{ DESCRIPTION } & RECYCLE & NON-RECYCLABLE \\
\hline Site Clearing Debris & 19,000 & 20,000 \\
\hline Mixed Rubble & 2,000 & 2,000 \\
\hline Wood-Solid & 73,500 & 37,000 \\
\hline Wood-Manufactured & 73,500 & 44,000 \\
\hline Metals & 38,000 & 38,000 \\
\hline Concrete & 6,000 & 3,000 \\
\hline Pipe-Plastic & 2,000 & 2,500 \\
\hline Drywall & & 5,500 \\
\hline Asphalt-roofing & 400 & 400 \\
\hline Glass & 200 & 200 \\
\hline Other & 27,500 & 27,500 \\
\hline Municipal Waste & & 3,000 \\
\hline Sanitary Sewer (liquid) & 243,000 & 31,500 \\
\hline $\begin{array}{l}\text { Total Construction } \\
\text { Waste }\end{array}$ & & 215,000 \\
\hline
\end{tabular}

Note: Data in table converted to metric and rounded from original data 